\begin{abstract}
UNIVERSIDADE DE SÃO PAULO
FACULDADE DE FILOSOFIA LETRAS E CIÊNCIAS HUMANAS

DEPARTAMENTO DE LETRAS CLÁSSICAS E VERNÁCULAS
\end{abstract}

ENEDINO SOARES PEREIRA FILHO

A ética protestante e a contribuição da Escola Americana e do Mackenzie College para a formação da norma culta da língua portuguesa em São Paulo

VERSÃO CORRIGIDA

São Paulo

2021 


\section{ENEDINO SOARES PEREIRA FILHO}

A ética protestante e a contribuição da Escola Americana e do Mackenzie College para a formação da norma culta da língua portuguesa em São Paulo

Versão corrigida

Dissertação apresentada ao programa de pósgraduação do Departamento de Letras Clássicas e Vernáculas da Faculdade de Filosofia Letras e Ciências Humanas da Universidade de São Paulo para a obtenção do título de mestre em Letras

Área de concentração: Filologia e Língua Portuguesa

Orientadora: Prof. ${ }^{\stackrel{a}{ } \text { Dr. }} .{ }^{a}$ Marilza de Oliveira 
Autorizo a reprodução e divulgação total ou parcial deste trabalho, por qualquer meio convencional ou eletrônico, para fins de estudo e pesquisa, desde que citada a fonte.

Catalogação na Publicação

Serviço de Biblioteca e Documentação

Faculdade de Filosofia, Letras e Ciências Humanas da Universidade de São Paulo

P $436 e$

Pereira Filho, Enedino Soares

A ética protestante e a contribuição da Escola Americana e do Mackenzie College para a formação da norma culta da língua portuguesa em São Paulo / Enedino Soares Pereira Filho; orientadora Marilza de Oliveira - São Paulo, 2021. $188 \mathrm{f}$.

Dissertação (Mestrado)- Faculdade de Filosofia, Letras e Ciências Humanas da Universidade de São Paulo. Departamento de Letras Clássicas e Vernáculas. Área de concentração: Filologia e Língua Portuguesa.

1. História social da língua portuguesa. 2. Escola americana e Mackenzie college. 3. Colocação

pronominal em orações infinitivas preposicionadas. I. Oliveira, Marilza de, orient. II. Título. 


\section{ENTREGA DO EXEMPLAR CORRIGIDO DA DISSERTAÇÃO/TESE}

\section{Termo de Ciência e Concordância do (a) orientador (a)}

Nome do (a) aluno (a): Enedino Soares Pereira Filho

Data da defesa: 19/05/2021

Nome do Prof. (a) orientador (a): Marilza de Oliveira

Nos termos da legislação vigente, declaro ESTAR CIENTE do conteúdo deste EXEMPLAR CORRIGIDO elaborado em atenção às sugestões dos membros da comissão Julgadora na sessão de defesa do trabalho, manifestando-me plenamente favorável ao seu encaminhamento e publicação no Portal Digital de Teses da USP.

São Paulo, 26/08/2021

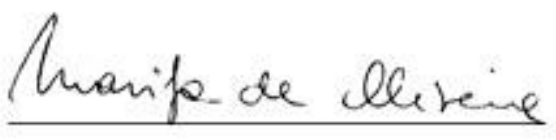


Nome: PEREIRA FILHO, Enedino Soares

Título: A ética protestante e a contribuição da Escola Americana e do Mackenzie College para a formação da norma culta da língua portuguesa em São Paulo

Dissertação apresentada ao programa de pós-graduação do Departamento de Letras Clássicas e Vernáculas da Faculdade de Filosofia Letras e Ciências Humanas da Universidade de São Paulo para a obtenção do título de mestre em Letras

Aprovado em:

Banca examinadora

Prof. Dr.:

Instituição:

Julgamento:

Prof. Dr.:

Instituição:

Julgamento:

Prof. Dr.:

Instituição:

Julgamento: 
Ao meu pai, que mesmo não entendendo muito bem o que eu estava fazendo, sempre me apoiou incondicionalmente. 


\section{AGRADECIMENTOS}

À minha orientadora, Marilza de Oliveira, por sua paciência comigo e pela inigualável competência e erudição com a qual me ajudou a conduzir este trabalho.

À minha mãe, Mercedes, por ter me concedido as graças de existir e de estudar, por vezes, em condições adversas.

À minha esposa e companheira, Fabiana Oshiro, que me inspirou certeza e confiança sempre, principalmente nas horas mais difíceis.

À minha filha, Heloísa, pelas horas e mais horas nas quais deixamos de brincar para que eu pudesse chegar até aqui.

A toda minha família e amigos, em especial, a minha sobrinha, Maria Clara, por ter me ajudado a revisar o texto submetido à banca de qualificação.

Aos professores Carlos de Almeida Prado Bacellar e Maria Aparecida Torres de Moraes pelas contribuições no exame de qualificação.

Ao Centro histórico e cultural da Universidade Presbiteriana Mackenzie.

Ao Arquivo histórico presbiteriano de São Paulo. 
"The fight is not with persons but with principles."

(MACKENZIE COLLEGE, 1909) 


\section{Resumo}

Nesta dissertação, analisamos orações infinitivas preposicionadas (OIP's) produzidas pela Escola Americana / Mackenzie College de São Paulo entre os anos de 1889 e 1923, observando a posição dos clíticos pronominais e comparando-a com aquela usada por outras comunidades linguísticas. O objetivo desta análise é conferir de qual norma de colocação pronominal a comunidade Mackenzie, recéminstaurada no Brasil, se aproximava, a saber, as normas linguísticas do português europeu (PE), do português vernacular brasileiro (PVB), do português republicano (PEPR) ou do português literário brasileiro (PLB) em uso por outros grupos já existentes nessa cidade. A partir de preceitos teóricos de áreas como a história social da língua portuguesa, da sociolinguística variacionista e da sociolinguística histórica, analisamos a predominância da ênclise em OIP's nos documentos produzidos pelo Mackenzie, dado que esse tipo de colocação pronominal era considerado prestigiado pela elite letrada brasileira na virada do século XIX para o $X X$. Além disso, foi imprescindível construir um panorama histórico, social e cultural que envolvesse tanto a comunidade Mackenzie quanto o contexto no qual ela estava inserida, assim como suas origens para verificarmos como seus ideais religiosos e políticos influenciavam suas escolhas linguísticas. Partimos, pois, da Reforma protestante do século XVI, passando pela Contrarreforma, Protestantismo estadunidense, Catolicismo brasileiro, inserção do protestantismo no Brasil, para chegarmos na constituição do ethos mackenzista, através de alguns processos de referenciação e estratégias argumentativas verificados em seus escritos. Finalmente, concluímos que o padrão de colocação dos clíticos pronominais em OIP's se assemelha ao dos literatos brasileiros (PLB), demonstrando que o projeto mackenzista optou por um modelo de língua local e atual, sobretudo para compor o cânone escolar e para constituir a norma culta da língua portuguesa paulistana de então.

Palavras-chave: Clíticos. Mackenzie College. Primeira república. História social. 


\section{Abstract}

In this dissertation, we analyze prepositional infinitive clauses (PIC's) produced by the Escola Americana / Mackenzie College of São Paulo during the period of 1889 and 1923, observing the position of the pronominal clitic and comparing it with that used by other speech communities. The purpose of this analysis is to check which norm of pronominal placement the Mackenzie community, recently established in Brazil, came close to, namely, the linguistic norms of European Portuguese (EP), Brazilian Vernacular Portuguese (BVP), Republican Portuguese (RP) or Brazilian Literary Portuguese (BLP) in use by other groups already existing in that environment. Based on theoretical precepts from areas such as the social history of the Portuguese language, variationist sociolinguistics and historical sociolinguistics, we analyzed the predominance of PIC's enclisis in documents produced by Mackenzie, given that this type of pronominal placement was considered prestigious by the Brazilian literate elite at the turn of the 19th to the 20th century. In addition, it was essential to build a historical, social and cultural panorama that involved both the Mackenzie community and the context in which it was inserted, as well as its origins to verify how its religious and political ideals influenced its linguistic choices. We started, therefore, from the Protestant Reformation of the 16th century, going through Counter-reform, American Protestantism, Brazilian Catholicism, insertion of Protestantism in Brazil to arrive at the constitution of the Mackenzist ethos, through some referencing processes and argumentative strategies verified in their writings. Finally, we conclude that the pattern of placement of pronominal clitic in OIP's is similar to that of Brazilian literati (BLP), demonstrating that the Mackenzist project opted for a local and current language model in its time, especially to compose the school canon and to constitute the linguistic norm of the Portuguese language of São Paulo at that time.

Keywords: Clitics. Mackenzie College. The First Brazilian Republic. Social history. 


\section{LISTA DE FOTOGRAFIAS, QUADROS, TABELAS E GRÁFICOS}

Fotografias

Figura 1: Martinho Lutero

Figura 2: João Calvino

Figura 3: Bíblia traduzida por Lutero em 1536

Figura 4: Landing of the Pilgrims on Plymouth, de Peter Rothermel, 1869

Figura 5: Anchieta e Nóbrega na cabana do Pindobuçu, Benedito Calixto (1920)

Figura 6: George Chamberlain

Figura 7: Mary Ann Annesley

Figura 8: Horace Lane

Figura 9: Estudantes e professores do curso superior do Mackenzie em 1905

Figura 10: Dormitório do Mackenzie College construído entre 1904 e 1905

Quadros

Quadro 1: Alunos eminentes do Mackenzie durante o período de 1889 a 1895.

Quadro 2: Atividades femininas

Quadro 3: Atividades masculinas

Quadro 4: Grade curricular Mackenzie College a partir de 1896

Quadro 5: Matrículas de alunos no Mackenzie de 1889 a 1899

Quadro 6: Referenciação no discurso do orador oficial (Cavalheiro, 1915)

Quadro 7: Programa de estudos de língua portuguesa

Tabelas

Tabela 1: Alunos pela nacionalidade paterna (1875-1885)

Tabela 2: Alunos por nacionalidade: 1896 a 1899

Tabela 3: Quadro referencial ao longo dos anos: Escola X Escola Americana

Tabela 4: Colocação pronominal $X$ tipo de pronome

Tabela 5: Ênclise: correlação de pronome e preposição

Gráficos

Gráfico 1: Ênclise em OIP's ao longo dos séculos em Portugal

Gráfico 2: Ênclise em OIP's retiradas de cartas pessoais de escritores portugueses

Gráfico 3: Ênclise em OIP's retiradas de cartas pessoais de literatos brasileiros

Gráfico 4: Ênclise em OIP's entre os intelectuais republicanos paulistas

Gráfico 5: Ênclise em OIP's em cartas públicas de políticos brasileiros

Gráfico 6: Dados gerais da colocação pronominal: Mackenzie

Gráfico 7: colocação pronominal de acordo com preposições

Gráfico 8: Colocação X tipo de pronome 
Gráfico 9: Ênclise: correlação de pronome e preposição

Gráfico 10: Ênclise Mackenzie X escritores românticos do séc. XIX

Gráfico 11 - Ênclise: Mackenzistas X M.Assis

\section{LISTA DE ABREVIAÇÕES}

OIP's - Orações infinitivas preposicionadas

PB - Português do Brasil

PE - Português europeu

PVB - Português vernacular brasileiro

PEPR - Português da elite paulista republicana

PLB - Português literário brasileiro 


\section{SUMÁRIO}

INTRODUÇÃO

CAPÍTULO I - Projetos educacionais protestantes na luta pela hegemonia ideológico-cultural

1.1. Origens do Protestantismo .12

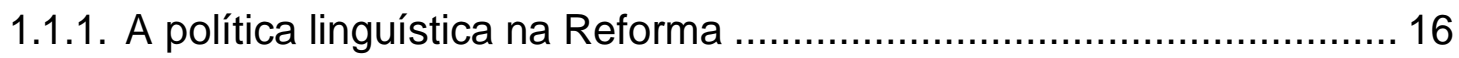

1.2. A cultura protestante nos Estados Unidos ……......................................... 19

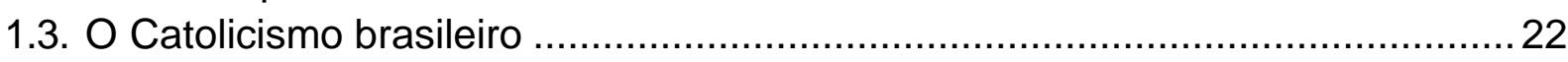

1.4. A inserção dos protestantes no Brasil no século XIX .....................................25

1.5. A missão presbiteriana: divisões de lá e cá ................................................... 31

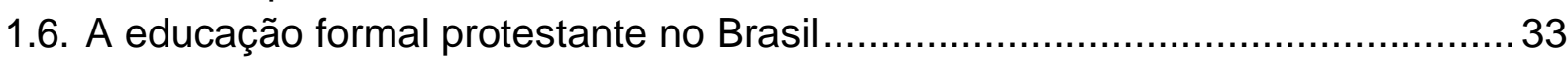

1.7. A educação presbiteriana em São Paulo .................................................... 38

CAPÍTULO II - CONSTITUIÇÃO DA COMUNIDADE MACKENZIE

2.1 A missão educacional presbiteriana no projeto civilizatório................................ 40

2.2. De Escola Americana a Mackenzie College ................................................. 42

2.3. Percalços na caminhada protestante da Escola Americana............................. 44

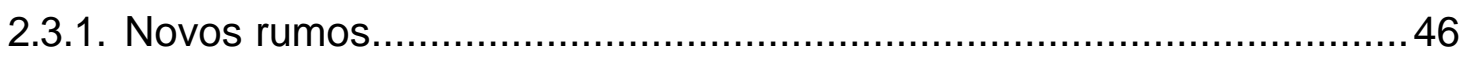

2.4. Centro educacional Mackenzie: a estrutura dos cursos ................................54

2.5. A recepção do Mackenzie pela sociedade paulistana

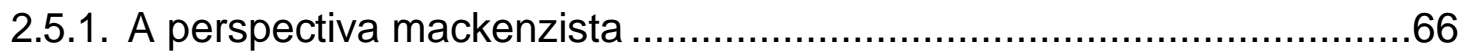

2.5.2. A recepção da perspectiva externa ao Mackenzie ..............................69

2.6. O Mackenzie e a construção do ethos da nova elite paulistana........................ 70

CAPÍTULO III - A tessitura do texto e a referenciação: a construção do ethos da comunidade Mackenzie

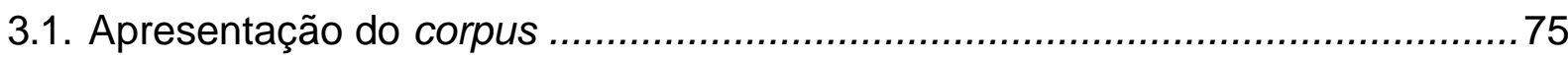

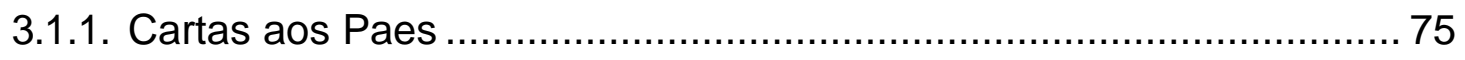

3.1.2. Prospectos da Eschola Americana/Mackenzie College ...................... 78

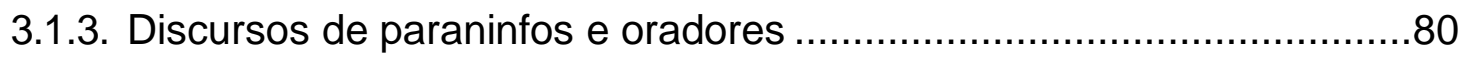

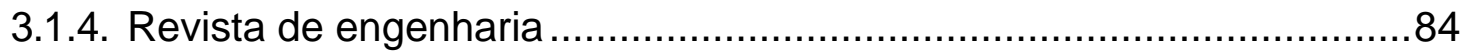

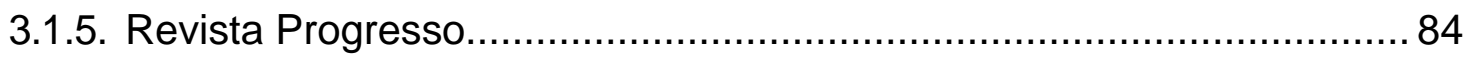

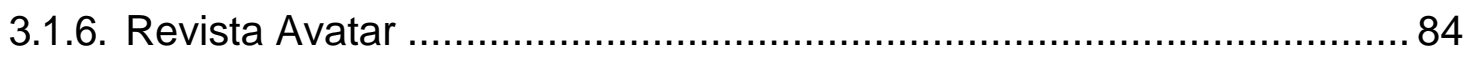

3.2. Estratégias de referenciação: a perspectiva Mackenzista.............................. 85

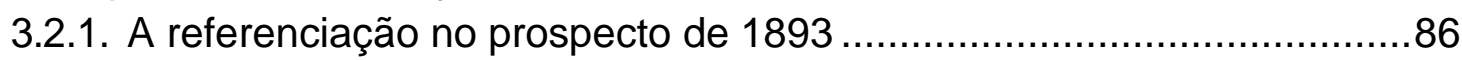

3.2.2. A referenciação nas Cartas aos Paes ............................................. 93

3.3. Tessitura e referenciação no discurso do orador oficial .................................102

3.4. A tessitura dos discursos dos paraninfos ................................................107

3.5. A referenciação nos discursos dos paraninfos .........................................114

3.6. As teias de referenciação: o ETHOS MACKENZISTA ………….................120 
CAPÍTULO IV - COLOCAÇÃO PRONOMINAL PAULISTANA: O CASO DA COMUNIDADE MACKENZIE

4.1. A língua portuguesa nos primórdios da Escola Americana ............................. 122

4.2. A Colocação pronominal em orações infinitivas preposicionadas .................... 129

4.2.1. A ênclise como símbolo de prestígio.............................................130

4.2.2. A colocação pronominal nas OIP's em gramáticas normativoprescritivas 133

4.2.3. A colocação pronominal em OIP's: alguns perfis

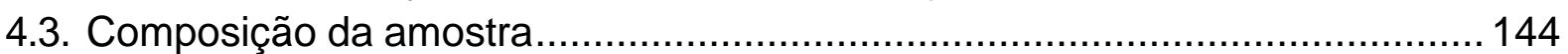

4.4. Bases teóricas e pressupostos metodológicos............................................. 145

4.5. Resultados da análise da colocação pronominal na comunidade mackenzista 150

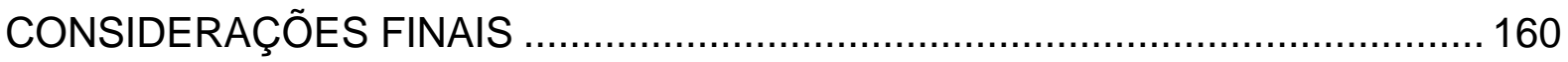

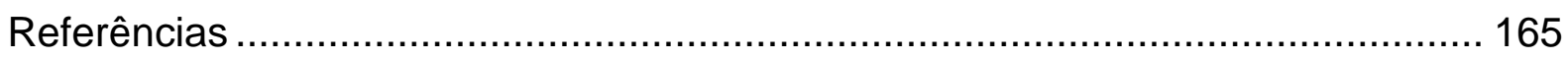

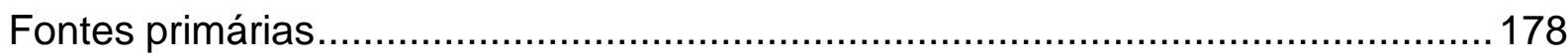




\section{Introdução}

Em um de seus argutos textos - As Religiões no Rio - sobre os diferentes eventos na cidade do Rio de Janeiro do início do século XX, Paulo Barreto, sob o pseudônimo de João do Rio, traçava o perfil de diferentes religiões que pululavam na cidade e ganharam legitimidade após a quebra da relação Estado-Igreja provocada pela Constituição da República. O título, além de situar localmente um fenômeno, projeta a metáfora da descarga ou do afluxo de um rio que, por meio de seus afluentes, drena e revitaliza o terreno das crenças. Entre as religiões que fluíam nessas correntes estava o protestantismo da igreja presbiteriana que eliminava a intercessão de papas, santos e imagens da relação do homem com Deus. Sem apelo à retórica, João do Rio expunha "secamente", como ele mesmo afirmava, as peculiaridades do protestantismo que suprimia as muletas que amparavam os católicos em suas trajetórias de vida, entre as quais estava a autoridade do papa como chefe da igreja, a intercessão dos santos às causas dos fiéis, o culto às imagens, os sete sacramentos (reduzindo-os a dois: batismo e comunhão), o reconhecimento do casamento religioso e a realização de missas em sufrágio das almas:

Qual é, afinal, secamente, em poucas palavras, o modo por que a Igreja Presbiteriana difere da Igreja Romana?

Não considera o Papa como chefe, nem tolera a sua infalibilidade, não crê na intercessão dos santos, que estão na glória e nenhum poder tem neste mundo, não aceita o celibato clerical, considerandoo uma inovação funesta [...] de Gregório VII, no século XI; não admite o culto das imagens, uma infração ao 2. mandamento do Decálogo; crê que Jesus Cristo ressuscitou e está vivo e reina como único chefe da sua igreja; crê no único fundamento, na única regra da Religião Cristã, a Palavra de Deus, a Bíblia, e prega que Deus, onipotente, onisciente e onipresente, é único apto a ouvir as orações dos homens. Só aceita dois sacramentos, o Batismo e a Comunhão, os únicos instituídos por Jesus Cristo; só reconhece o casamento civil, sobre o qual impetra a bênção de Deus; não admite o purgatório [...] diante das santas escrituras. [...]

Proíbe as missas em sufrágio das almas, porque Jesus nunca rezou missas, e crê que o homem é salvo de graça pela fé viva, como crê na ressurreição, na regeneração, na vida eterna e no juízo final. Todo o seu culto se resume na leitura das escrituras, em sermões explicativos, em orações a Deus, e no primeiro domingo de cada mês na celebração da Eucaristia... (RIO, 1976, p.40) 
Publicado no período das transformações estruturais da cidade carioca promovidas pelo prefeito Pereira Passos e pelas campanhas de saneamento do diretor geral de Saúde Pública - Oswaldo Cruz, o livro de João do Rio, assim como as crônicas de outros escritores, como Lima Barreto, desfechava as feridas sociais sob o processo de assepsia, expunha a multiplicidade de religiões que compartilhavam espaços contíguos, ainda que não oficialmente, e, paradoxalmente, dava a ver os dogmas de uma religião que propugnava higienização também no âmbito espiritual.

Como os protestantes se dedicaram também à educação, os métodos e os conteúdos programáticos escolares impregnados de espírito religioso e místico do catolicismo que antes reinava de modo absoluto no Brasil também eram revistos em função da concepção de mundo respaldada pela ética do trabalho. O contraponto eram os colégios católicos, em particular os da Companhia de Jesus, os primeiros a instaurarem um sistema organizado de educação no planalto paulistano, e que, após exílio compulsório de pouco mais de um século ${ }^{1}$, se reinseriram no mercado educacional instalando o Colégio São Luís, na cidade de Itu, São Paulo.

Nos tempos coloniais ${ }^{2}$ os jesuítas atendiam os filhos de colonos, priorizando o ensino secundário e almejando, com isso, formar uma restrita elite intelectual branca constituída por religiosos e burocratas a serviço da Coroa portuguesa (MARCíLIO, 2005, p.25). Na volta ao exercício do magistério, após mais de um século, se dedicaram ao ensino dos filhos da oligarquia cafeeira (COLSATO, 2016, p.80).

Os jesuítas usavam um programa de estudos extremamente organizado, chamado Ratio Studiorum introduzido no Brasil em 1639, que prescrevia o que deveria ser ensinado e sobre o modo como se desenvolveriam os processos de ensino-aprendizagem. Os estudos, cujos conteúdos se dividiam em disciplinas que tinham base epistemológica ortodoxicamente calcada em Aristóteles e São Tomás de Aquino, se desenvolviam por meio do exercício de repetição de modelos auctoritates - e de exemplos explorados em latim nas disputationes escolásticas. Dentro desse quadro, em que se processava a informação pela emulação e pela

\footnotetext{
1 Os jesuítas haviam sido expulsos em 1759.

2 Num primeiro momento, o índio ou "gentil da terra" era considerado foco de processos educacionais que visavam não só a conversão ao Catolicismo, mas também a alfabetização e familiarização com a língua portuguesa. Mas logo foi alvo apenas do processo de conversão, cabendo ao filho do colono a educação.
} 
memorização, a retórica jesuítica se reduzia à exploração de tropos e de figuras (MARCÍLIO, 2005, p.27).

Após o sistema de educação jesuítica ter sido banido do Brasil em 1759, com a implementação da Reforma pombalina, mantiveram-se as estruturas socioculturais da colônia tal como estavam: o Brasil continuava com o acesso proibido a qualquer tipo de imprensa ou tipografia, os livros eram censurados e não havia ensino superior, pois inexistiam faculdades ou universidades. Fecharam-se os colégios jesuíticos e instituíram-se as chamadas Aulas régias:

Cada aula régia constituía uma unidade de ensino, com professor único, instalada para determinada disciplina. Era autônoma e isolada, pois não se articulava com outras nem pertencia a escola alguma, nem mesmo a nenhum plano geral. Não havia currículo, no sentido de um conjunto de estudos ordenados e hierarquizados, nem a duração prefixada se condicionava ao desenvolvimento de qualquer matéria. $\mathrm{O}$ aluno se matriculava em tantas "aulas" quantas fossem as disciplinas que desejasse. (CHAGAS, 1978, p.119)

Abalizado em aulas avulsas, o ensino secundário foi o mais destacado no período das Reformas pombalinas. Provido de caráter imediatista, tinha a função exclusiva de preparar jovens para os estudos superiores na Europa - sobretudo na Universidade de Coimbra - e, posteriormente, no Curso jurídico do Largo de São Francisco em São Paulo - fundado em 1827 - o que aconteceria de modo recrudescente até o final do Segundo Império. Integrava-se de conteúdos de gramática latina, retórica, filosofia e teologia decorados por métodos de memorização os quais eram avaliados através de exames avulsos (MARCíLIO, 2005, p.85).

Durante todo o império, o segmento educacional foi negligenciado pelos poderes público e privado. As iniciativas tomadas com a intenção de ampliar e melhorar a educação em São Paulo sempre foram pontuais e efêmeras, advindas de um ou outro governante ou homem da elite. Prevaleciam cursos de primeiras letras, aulas régias, avulsas e, sobretudo, a educação familiar feita por parentes ou preceptores. As poucas escolas existentes eram isoladas umas das outras. Os métodos de ensino utilizados continuavam sendo ineficientes: separação por sexo (com muita negligência ao ensino feminino); ensino individual através de processos 
de leitura em voz alta, repetição e memorização; violências física e moral excessivas e descontinuidade dos processos de ensino-aprendizagem. As escolas eram escassas, pequenas, autônomas, incomunicáveis entre si e, muitas vezes, conduzidas por apenas um professor que era responsável por instruir simultaneamente grupos heterogêneos compostos por crianças e adolescentes de idades diferentes. Os professores eram desvalorizados e, muitas vezes, sequer reconhecidos, tinham formação acadêmica repleta de lacunas, trabalhavam excessivamente, ganhavam pouco e lecionavam em lugares inapropriados como em suas residências, salas alugadas por eles mesmos ou em ambientes doados por proprietários de terras. As aulas régias, durante todo o século XIX, não seguiam nenhum tipo de diretriz de ensino nem tampouco metodologias específicas para as necessidades de alunos e professores; os cursos não eram graduados ou seriados e não havia equipe gestora, apenas um professor por escola:

Nas aulas régias e nas escolas de professores de palácio, ensinavase só a ler, escrever e contar. O método de leitura era a soletração [...]. A escrita começava com o debujo de pauzinhos, depois de letras; mais tarde dava-se os traslados. As contas eram passadas em ardósias [...] decorava-se a tabuada [...]. Usava-se a vara de marmelo, a palmatória, o puxão de orelha, o coque, o ajoelhar sobre o milho, o pôr um pé no canto, a prisão após o recreio e após as aulas, os xingamentos. Nas escolas particulares, a humilhação era maior: as orelhas de burro, o quarto escuro, a privação de alimentos, a exposição do faltante perante as classes reunidas, o amedrontar com o inferno etc. (ESCOBAR, J.R., 1933, p.187)

Instaurada a república, fazia-se mister renovar, inovar e ampliar o sistema educacional já existente. Para isso, foi sancionada a lei 169 de 1892-93 que previa, entre outras coisas, a criação e o desenvolvimento da educação infantil, do primário e do ginásio. A Escola Normal, que já existia, passou por profundas reformulações, e recebeu maior atenção e investimentos das autoridades, implementando a Escolamodelo, numa parceria entre o Estado e a direção da escola protestante presbiteriana (EPP) ${ }^{3}$ de São Paulo. (MARCÍLIO, 2005, p.102)

\footnotetext{
3 Para nos referirmos a essa escola adotaremos indiferentemente a sigla EPP (Escola Protestante Presbiteriana de São Paulo) ou simplesmente "Mackenzie"; usaremos "Colégio Mackenzie" ou "Mackenzie College" para nos referirmos ao complexo educacional que se formou a partir da implementação de diferentes cursos, em particular o de Engenharia, em oposição à "Escola Americana", que se restringiu ao ensino primário.
} 
A instalação da escola protestante na cidade de São Paulo é marcada pela imigração de povos anglo-saxões motivada por problemas político-econômicos de seus países, adensada pelas ondas imigratórias da virada do século subsidiadas pelo governo paulista para substituir a mão de obra escrava. Junto a esse fluxo de camadas populares não-católicas e, dando prosseguimento ao movimento civilizatório de selo francês (além de outros) iniciado com as Missões Francesas licenciadas por D. João VI (SCHWARCZ, 1998, p.246), a cidade acolhia escolas confessionais católicas europeias com as quais o Mackenzie rivalizava em busca de um nicho protestante. O momento era tenso, fosse pela ruptura da relação IgrejaEstado que levou à perda do monopólio da Igreja Católica nos atos civis, promovida pela Constituição Republicana, fosse pela instabilidade política nos anos que antecederam e nos primeiros anos do regime republicano (CARVALHO, 1997, p.3637).

Nessa conjuntura tensa, o Mackenzie se inseriu e se projetou simbolicamente como uma instituição necessária para a implementação de um sistema educacional formal que abrangesse todos os níveis de ensino e fomentasse um grupo seleto de engenheiros, arquitetos e administradores da indústria e do comércio cujas intenções e ações reformistas - como o nacionalismo e o modelo republicano estadunidense - objetivavam o crescimento econômico e as modernizações política e social de seus pares. Para tanto, a comunidade Mackenzie precisou compartilhar problemas e resoluções que tornaram seus integrantes mutuamente dependentes uns dos outros, fazendo com que agissem coletivamente em prol de um benefício comum. Obviamente, isso acabou criando tensões e conflitos sociais contra outros grupos já existentes, o que de certa forma ampliou a força e a coesão do Mackenzie como grupo linguístico e social.

Nesse período, língua, religião e raça formavam o tripé sobre o qual se articulavam ideias nacionalistas ${ }^{4}$, fato que não passou despercebido aos protestantes que apresentavam, como bem mostrou João do Rio, uma doutrina asséptica, livre de dogmas e de intermediários na relação do homem com Deus. Tal

\footnotetext{
4 Estudando o item "nação" no vocabulário político desde 1830, Chauí (2000) periodiciza o processo histórico da invenção da nação brasileira: i. "Princípio da nacionalidade": o discurso vincula nação e território (1830-1880); ii. "Ideia nacional": articula-se à língua, religião e raça (1880-1918); iii. "Questão nacional": sublinha a consciência nacional (1918-1960).
} 
assepsia espiritual repercutia na escolha da língua portuguesa que presidiria 0 ensino na escola protestante, em substituição ao francês.

A essa altura, com a cisão entre literatos e políticos e a subida ao poder da geração que compunha o movimento intelectual de $1870^{5}$ (ALONSO, 2002) surgiam duas normas linguísticas cultas evidenciadas na colocação pronominal em orações infinitivas preposicionadas: a norma dos republicanos e a norma dos literatos (OLIVEIRA, 2021).

Diante dos modelos linguísticos que veremos neste trabalho, colocamos as seguintes perguntas:

i. A que norma linguística a escola protestante se conformou na implementação de seu projeto nacionalista de articular língua e religião?

ii. Como explicar a escolha dessa norma pelo viés da sócio-história da língua?

As respostas a essas questões exigem a aproximação do estudo da língua às pessoas que a usavam em suas atividades, de modo que por meio da história social, procuraremos revelar a associação entre a norma linguística e a concepção de mundo dessas pessoas.

O estudo de história social da linguagem, tal como o concebemos neste trabalho, consiste principalmente na indagação sobre a existência de motivações históricas que, eventualmente, expliquem ou justifiquem a ocorrência de variação linguística dentro de grupos sociais específicos. Trata-se de análises estatísticas que correlacionam variáveis linguísticas a grupos sociais, considerando como pressupostos a heterogeneidade, variação e mudança linguísticas intrínsecas a toda e qualquer língua natural. Os estudos linguísticos tiveram um grande avanço a partir da teoria da variação e mudança linguísticas proposta por Weinreich, Labov \& Herzog (1968) e Labov (1972) e (2001), sinalizando que, quando não há mudança, "a variação se estabiliza para atuar como índice de diferenças sociais" (CAMACHO, 2013, p.232)

A sociolinguística variacionista, em sua vertente laboviana, correlacionou muito bem variantes linguísticas às comunidades que as produziram, mas não se

\footnotetext{
${ }^{5}$ De acordo com Alonso (2002), até a década de 1870 não se fazia distinção entre literato e
} político. 
aprofundou em explicá-las socio-historicamente (PEREIRA, 2010, p.89-92). Aparentemente, essa subárea da linguística não tinha como objetivo analisar a correlação de fatores extralinguísticos e linguísticos com a história e, mesmo evidenciando parte do aspecto social da produção linguística, recuperou superficialmente suas circunstâncias históricas e relações com a comunidade linguística, fornecendo uma concepção de língua, em parte, desintegrada da realidade social.

Em outras palavras, apesar de se propor a analisar o peso de fatores sociais, a sociolinguística variacionista no Brasil pouco avançou na compreensão da formação histórica das diferenças sociais - passíveis de virem à tona por meio da variação linguística - e analisou superficialmente as tensões que envolviam grupos sociais distintos e seus igualmente distintos modos de falar e de escrever. Entretanto, usaremos alguns instrumentos de análise provenientes dessa subárea da linguística, assim como os de outra subárea conhecida como sociolinguística histórica, que tem como princípio o estudo da língua como objeto dinâmico em perspectiva histórico social.

A relativização das fronteiras entre língua, cultura e história são essenciais nesse processo, fazendo com que disciplinas de grandes áreas das ciências humanas como linguística, literatura, história, sociologia e antropologia possam atuar transversal e complementarmente, a fim de fornecer uma dimensão mais ampla do objeto de estudo em questão (PEREIRA, 2010, p.89-92). Dado o passo em direção à relação entre história social e comunidade linguística, torna-se possível explicar a formação da identidade social como sendo constitutiva da língua e, no limite, constituída na língua. A identificação da comunicação entre produção linguística e lugar social do falante, partindo de uma variável linguística realizada, resulta numa concepção de língua como fato social, operando uma mudança de foco da língua pertencente ao indivíduo para a língua como interação social. A variação linguística serve, portanto, como indicadora de posições, atividades e de características sociais que se interpenetram em relações mais ou menos tensas e descontínuas, o que põe em questão o conceito de comunidade linguística homogênea, como veremos mais adiante (PEREIRA, 2010, p.89-92). 
A análise e interpretação de informações do passado, à luz de uma concepção histórica e social da língua deve, pois, ir além do trabalho de descrição, não se restringindo apenas a concluir qual é a variante privilegiada por determinado grupo social. É de fundamental importância reconstituir o contexto histórico gerador do processo de variação linguística para, com isso, interpretar a preferência que é dada a certas formas linguísticas em detrimento de outras. Desse modo, torna-se possível conjecturar o valor sociocultural das variedades linguísticas para compreender a língua não só como um meio de comunicação, mas também como um bem simbólico capaz de congregar e fortalecer coletividades em torno de ideias, projetos e identidades. O desafio está em descobrir como o significado social é acoplado a uma variável linguística; como a língua pode se tornar um marcador identitário (RIBEIRO, 2015, p.13). Nesse sentido, o objetivo fundamental da sociolinguística seria cruzar informações concernentes aos aspectos sociais da linguagem com aspectos linguísticos das comunidades sociais (CAMACHO, 2013, p.250), sempre acompanhando o desenvolvimento histórico dos grupos para, desse modo, entender as relações simbólicas de poder e construção identitária que podem ser extraídas e construídas pela variação linguística. Para tanto, a análise e a interpretação devem manter um contato epidérmico entre disciplinas diversas, trabalhando em suas fronteiras (RIBEIRO, 2015, p.13), a partir da escolha de objetos linguísticos 'negligenciáveis' que deem pistas (GINZBURG, 1990) da construção identitária dos membros de comunidades linguísticas distintas e suas respectivas gramáticas.

Nesta empresa multidisciplinar, incluímos parte da agenda do Projeto História do Português Brasileiro (PHPB), em princípio, na sua vertente paulista (PHPP) "reconstituindo o percurso histórico do português paulista" no que se refere, mais genericamente, ao trabalho com a história social do PB (CASTILHO, 2018, p.27-8). Também abordamos alguns aspectos da história da cultura escrita no Brasil, no que concerne ao estudo da língua portuguesa, escolarização e suas interfaces, "analisando o desenvolvimento do processo de escolarização do ensino da língua portuguesa no Brasil colonial e pós-colonial" e "avaliando os métodos e instrumentos pedagógicos disponíveis para o período referido em relação ao estudo da língua portuguesa" (SARTORI, 2018, p.134-6). Ainda no âmbito desse projeto, organizamos o corpus histórico com base em alguns critérios de tradições discursivas, sobretudo 
no que diz respeito à questão da história social e à questão do contato entre normas linguísticas distintas (KEWITZ; SIMÕES, 2018, p.210-214). Finalmente, traçamos os perfis sociais dos redatores respondendo ao conjunto mínimo das seguintes questões: o que, quando, onde, quem, para quem e por que determinados textos foram escritos (LOBO; CARNEIRO, 2018, p.292-311). Vale a pena ressaltar a importância dada por esse projeto a um aprofundamento do estudo histórico da língua portuguesa que contempla, de maneira ampla e detalhada, aspectos sociais estruturantes da linguagem, configurando-a como um fenômeno complexo dos pontos de vista histórico, social, cultural e das relações humanas em geral:

Conhecer como se falava ou escrevia o português em espaços
comunicativos específicos do território brasileiro numa determinada
época implica estudar a história de seus falantes / escritores em
todos os seus aspectos, bem como dos ouvintes / leitores dos textos.
Um deles diz respeito à genealogia dos interlocutores, de modo que
se conheça sua formação escolar e / ou acadêmica, suas
experiências, seu papel social naquela sociedade, suas redes de
relações ao lado das transformações políticas, econômicas, culturais
e sociais pelas quais essa sociedade passava. Além desses aspectos, é preciso levar em conta como se formavam as sociedades paulistas, isto é, como essas sociedades eram organizadas hierarquicamente, quem era responsável por quais atividades, quem detinha poderes administrativos e assim por diante. Esses dados vinculam-se ao grau de simetria entre os interlocutores, e consequentemente, às escolhas linguísticas no momento da produção do texto (KEWITZ; SIMÕES, 2018, p.211).

Dentro desse enfoque, este trabalho visa a apresentar uma pequena amostragem do que foi a inserção do Mackenzie em São Paulo, no final do século XIX, dos pontos de vista histórico, social, cultural e linguístico. Isso de maneira abrangente e, ao mesmo tempo, condensada, sempre partindo de documentos históricos produzidos pelo grupo social que fundou e consolidou essa instituição de ensino. A análise documental de fontes primárias se concentra em aspectos culturais e linguísticos do cotidiano escolar da comunidade linguística da Escola Americana e do Mackenzie College. Esses documentos configuram recortes da realidade espaçotemporal que estudamos, oferecendo vestígios, detalhes e pistas discretas menos evidentes dessa investigação (GINZBURG, 1990; LE GOFF; NORA, 1995). Baseando-nos na chamada História nova, buscamos analisar estruturas, relações 
sociais e a escuta de vozes diversas que expressam mentalidades coletivas e pontos de vista de classes mais ou menos privilegiadas (RIBEIRO, 2015, p.11-13).

No primeiro capítulo - apresentaremos um breve panorama da Reforma protestante europeia, iniciada no começo do século XVI e seus desdobramentos que contribuíram para uma concepção de mundo diferente da existente até então no Ocidente. Em seguida, veremos como se constituiu o sistema de religiões protestantes nos Estados Unidos, de onde viriam, ao Brasil, os presbiterianos fundadores do Mackenzie.

No segundo capítulo, investigaremos os objetivos e interesses comuns dos membros que constituíram o Mackenzie e o tornaram uma comunidade/grupo ${ }^{6}$ relativamente estável, do ponto de vista linguístico e social, em suas relações com os demais grupos que já integravam a sociedade paulistana com o advento da primeira república em 1889. A partir da história dessa instituição, mostraremos como foram implementadas as forças de conformidade ou processos de socialização, escolarização, acesso aos meios de comunicação da época, além das sanções que visavam a credenciar os aptos e a excluir aqueles que não se adaptavam ao modelo de formação mackenzista. Desse modo, será possível observar o grau de alinhamento ideológico dos membros que integravam essa comunidade, compreendendo por ideologia o conjunto de conhecimentos, atitudes, normas e valores que, compartilhados, permitem que haja uma convergência de opiniões, objetivos e interesses capazes de proporcionar coesão e sentimento de pertencimento a um determinado grupo social (VAN DIJK, 1998).

No terceiro capítulo, apresentaremos os textos que serviram de corpus para a análise sócio-histórica da variedade de língua portuguesa ${ }^{7}$ veiculada no Mackenzie entre os anos de 1889 e 1923. Além de uma breve apresentação de cada uma das amostras, mencionando suas características textuais, contextuais e algumas de suas peculiaridades. É o início de uma abordagem voltada para a história social da língua portuguesa, na qual realizaremos uma análise da tessitura textual através da análise do modo como a sociedade paulistana se referia à comunidade Mackenzie, e como

\footnotetext{
${ }^{6}$ Adotamos o nome Mackenzie para englobar a Escola Americana e o Mackenzie College.

7 Neste trabalho analisamos, entre outros gêneros, o Discurso de paraninfo, gênero discursivo cujo texto escrito é elaborado para ser veiculado na modalidade falada da língua. ( $\mathrm{N}$ do $\mathrm{A}$ )
} 
esta se referia a si mesma, a fim de construir seu ethos ${ }^{8}$ e, consequentemente, se afirmar no meio social em que se inseria.

Finalmente, no quarto capítulo, o foco de análise se concentrará na história social da língua portuguesa. Teceremos algumas considerações acerca da implementação e do uso da língua portuguesa no Mackenzie já em sua origem visto se tratar de uma escola estrangeira cuja língua nativa de seus fundadores era o inglês. Em seguida, será feita uma análise de cunho sociolinguístico cujo foco será a variação na posição de clíticos pronominais em orações infinitivas preposicionadas (OIP's), com o objetivo de compreender que gramática ou padrão gramatical de colocação pronominal era utilizado por essa comunidade linguística, procurando resgatar a contribuição do Mackenzie para a fixação de uma norma culta escrita da língua portuguesa em São Paulo no entresséculos XIX-XX. Essa análise será complementada pelas outras, feitas nos capítulos anteriores, que contemplam áreas do conhecimento com a história social, antropologia, sociologia, análise do discurso, linguística textual e literatura.

\footnotetext{
${ }^{8}$ A palavra ethos provém do grego antigo ñं0ऽ, que, para Aristóteles, tinha o significado de "caráter moral do orador" (ARISTÓTELES, 2005, 1356a). Neste trabalho, no entanto, adotaremos a concepção de ethos discursivo entendido como identidade, i.e., o enunciador constrói para o seu destinatário a imagem que ele quer que os outros tenham de si:

"As 'idéias' suscitam a adesão por meio de uma maneira de dizer que é também uma maneira de ser. Apanhado num ethos envolvente e invisível, o coenunciador faz mais que decifrar conteúdos: ele participa do mundo configurado pela enunciação, ele acede a uma identidade de algum modo encarnada, permitindo ele próprio que um fiador encarne. O poder de persuasão de um discurso deve-se, em parte, ao fato de ele constranger o destinatário a se identificar com o movimento de um corpo, seja ele esquemático ou investido de valores historicamente especificados" (MAINGUENEAU, 2008, p.29).
} 


\section{CAPÍTULO I - Projetos educacionais protestantes na luta pela hegemonia ideológico-cultural}

\subsection{Origens do Protestantismo}

Em um cômico depoimento sobre a repulsa em estudar em um colégio sob a regência de uma sebenta batina de padres e o desejo de estudar em um colégio protestante que incluía o esporte em seu programa, em respeito à máxima "mens sana in corpore sano", Pedro Nava desfia de suas memórias o diálogo entre sua mãe e uma amiga rica, dona Mariquinhas, sobre a difícil decisão de matricular o filho no colégio católico Claret ou no Colégio Metodista Anglo-Mineiro ${ }^{9}$ criado por ingleses.

[Minha mãe] tinha ouvido falar no [colégio] duns ingleses, que estava para se abrir e queria saber, de pessoa de confiança, se valia a pena o sacrifício de matricular-me nele. É que era caro como o diabo. Enfim... Vamos ver o que diz a Mariquinhas. Fomos e logo a d. Mariquinhas foi esculachando minha Mãe. Nada disso, Diva. Você está doida? Enfiar seus filhos no meio de metodistas? Os meus vão para o Claret e é lá que você vai pôr os seus. Eu, que estava doido pelo Anglo, quase ajoelhei para pedir a $\mathrm{D}$. Mariquinhas que calasse a boca e afastasse de minha vida da sombra sebenta da batina dos padres que ela inculcava. Saímos da visita meio enfiados e fomos andando pelo passeio. Na esquina, quem aparece? O próprio marido da D. Mariquinhas, o Dr. Lourenço Baeta Neves, com aquele seu riso franco e jovial e aquele jeitão que eu classificaria mais tarde como de um tipo que ficasse equidistante do Carlito e de Osvaldo Cruz. Por aqui? D. Diva. E vindo lá de casa? Que pena eu não ter chegado mais cedo. Não vê? Fui longe da cidade, dos lados do Cruzeiro, ao Ginásio Anglo-Mineiro. É. Fui matricular o Cecinho e o Roberto. Ah! A Mariquinhas fizera questão... Estou voltando entusiasmado com o colégio e com o diretor. Um cavalheiro admirável. É o Dr. Sadler, master of arts oxoniano. Nada, absolutamente nada! melhor para a mocidade que a educação que eles estão pretendendo dar. Mens sana in corpore sano. Minha Mãe não entendeu nem o inglês do Dr. Lourenço, nem o latim, tampouco que negócio era aquele de oxoniano. Mas o que ela bispou imediatamente é que a d. Mariquinhas, na sua posição de esposa de engenheiro ilustre, estava indignada de ver a amiga viúva e pobretona, pretender educar seus filhos sudras as mesmas condições dos pequenos brâmanes dela, Mariquinhas. Minha mãe chorando de raiva tomou o bonde Cruzeiro, recém-inaugurado para servir ao novo colégio, foi recebida pelo secretário-tesoureiro, Mr. Rose, pediu os estatutos, as instruções para o enxoval e matriculou-me imediatamente (NAVA, 2000, p.125).

\footnotetext{
9 Joseph Thomas Wilson Sadler, responsável pelo colégio anglo-mineiro de Belo Horizonte, pretendia suplantar o Ginásio Anglo-Brasileiro que existia na ocasião em São Paulo (NAVA, 2000).
} 
O testemunho de Nava mostra que a atuação dos protestantes no campo educacional era envolta em uma atmosfera ambígua de atração e desconfiança, derivada das tensões entre as confissões religiosas que disputavam pela formação ideológico-cultural da elite brasileira, as quais eram incorporadas pela população. Mas o mais interessante é que a desconfiança se desfazia pelo fato de que $d$. Mariquinhas deu informação falsa à mãe de Nava e já havia matriculado dois de seus filhos. Ao perceber ter sido enganada pelo capricho da amiga rica que criara uma fronteira entre seus filhos por meio dos colégios, recorreu ao secretáriotesoureiro a quem pediu os estatutos, que talvez nem leu, e igualmente matriculou o filho no colégio metodista.

A mãe de Pedro Nava não tinha tanta certeza sobre a mudança de escola, mas, por ter sido enganada pela amiga, optou imediatamente pela escola protestante (de viés metodista) em lugar do colégio católico. A educação protestante surgia, então, como opção de avanço e modernidade, como aliás acontecia com outros aspectos da vida social no Ocidente já cristianizado, desde os primórdios do reformismo europeu, como veremos abaixo.

A Reforma Protestante, movimento religioso iniciado na Alemanha no século $\mathrm{XVI}$, tinha por objetivo a priori remover da Igreja Católica algumas práticas e restrições estabelecidas pela Cúria Papal Romana, o que não foi alcançado de fato, pois os promotores da Reforma provocaram um cisma com o Catolicismo, de onde se derivaram as primeiras igrejas protestantes (ZACHMAN, 2004, p.23-24).

Outra linha de interpretação histórica afirma que a Reforma protestante do século XVI não passou de uma entre tantas tentativas de reformas ocorridas durante a Idade Média, reformas nas quais padres, monges, frades e outros representantes da Igreja católica se rebelaram contra o autoritarismo e as arbitrariedades promovidas pelo alto escalão católico, em busca de experiências religiosas baseadas em concepções teológicas do Cristianismo primitivo. Segundo essa linha de estudos, houve reformas nos séculos $X, X I I, X I V$ e $X V$, em lugares diferentes e fomentadas por grupos diferentes dentro do Catolicismo. Mesmo após a Reforma desencadeada por Lutero $^{10}$, muitas outras se propalaram pela Europa, dentre as

\footnotetext{
${ }^{10}$ Entre os religiosos e intelectuais que iniciaram o movimento protestante, destacam-se o padre, professor universitário e símbolo da Reforma Martinho Lutero [1483 - 1546], Andreas Bodenstein von Karlstadt [1480-1541], Philip Melanchthon [1497-1560], Ulrich Zwingli [1484-
} 
quais, podemos destacar o que alguns chamam de Protestantismo reformado, realizado por João Calvino. Foram "diversos movimentos teológicos e políticos com rumos e projetos próprios", mas a insurgência luterana foi que ganhou mais ressonância na historiografia oficial (MARSHALL, 2017, p.37). Talvez, o destaque que se dá à Reforma protestante seja porque esse movimento religioso ocorreu simultaneamente a outros movimentos culturais, sociais e políticos, como o aprimoramento da imprensa de Gutemberg, culminando no período histórico que alguns historiadores chamam de Renascença ou Renascimento. A esse propósito, deve-se salientar que há controvérsias sobre a ideia de que este tenha sido um movimento religioso antirrenascentista e reacionário e que tenha tido um verdadeiro impacto na sociedade europeia como um todo, visto que alguns autores afirmam não ter havido nenhum tipo de renascimento nas províncias germânicas onde se deu a Reforma luterana (CARPEAUX, 2008, p.480-481).

Em sua estruturação formal, a Reforma não visava a uma ruptura com a Igreja Católica. Os reformistas apenas almejavam implementar alguns ajustes que aproximassem o Catolicismo de princípios genuínos do Cristianismo. O foco da discórdia se referia a alguns dogmas provenientes de Roma que eram compreendidos como arbitrários pelos reformistas. Entre essas arbitrariedades, destacam-se as que se referem ao abuso na venda de indulgências; à multiplicidade de meios para entrar em contato com a divindade (as cartas de indulgência e toda a literatura hagiográfica medieval, por exemplo), que extrapolavam os ensinamentos bíblicos verificáveis nas Sagradas Escrituras judaico-cristãs; a intermediação entre Deus e seus fiéis por meio do uso de imagens de santos ou ícones que pudessem ser idolatrados (prática esta considerada feitiçaria pagã pelos protestantes); o voto de castidade dos padres; a hierarquia burocrática dos católicos - considerada

\footnotetext{
1531] entre outros. Todos eles frequentadores da Universidade de Wittemberg e simpatizantes de ideais que se contrapunham aos preceitos estabelecidos pela igreja Católica que tinha Roma como sua sede (ZACHMAN, 2004, p.25). Lutero está entre as figuras mais marcantes e controversas da história ocidental. Sua força insurgente, usada intensivamente contra a alta cúpula da igreja católica, se confundia com sua indiferença diante das grandes revoltas populares que ele mesmo ajudou a fomentar na Alemanha quinhentista; sua exímia capacidade de sensibilizar a nobreza alemã em favor de uma nova igreja reformada se misturava com a hipocrisia condescendente de aceitar, em sua velhice, o autoritarismo monárquico de príncipes germânicos (CARPEAUX, 2008, p.481-2). Em suma, a complexidade de um homem de formação medieval, movido por um sentimento religioso inabalável, que colocou a fé à frente e acima de qualquer outra coisa e que, no dia 31 de outubro de 1517 - ao expor suas 95 teses contra a venda de indulgências por parte da igreja católica - teve seu nome associado às revisões e mudanças de diversos conceitos e paradigmas culturais, políticos e sociais no mundo ocidental moderno.
} 
desnecessária pelos protestantes - pois envolvia uma estrutura de poder extremamente complexa, formada pelo Papa, cardeais, bispos, padres etc. Ademais, a índole muitas vezes considerada corrupta de alguns líderes católicos que, por meio da simonia, do nepotismo, do absenteísmo e da concubinagem clericais, por exemplo, obtinham vantagens simbólicas e materiais, defasando a imagem do Catolicismo do ponto de vista moral e ético (WALKER, 1985, p.419-420).

Como propostas para corrigir essas arbitrariedades, os reformistas sugeriram uma série de mudanças, dentre as quais se destacam a ampliação das liberdades individuais (um valor muito estimado, sobretudo por Lutero, que acreditava na compreensão individual da Bíblia e no conceito de livre arbítrio como elementos de conversão e formação do verdadeiro cristão); o trabalho como vocação ou dom transmitido por Deus (o que tornaria o cristão um ser produtivo do ponto de vista intramundano e o que, segundo Weber (1996), viria a contribuir enormemente para o desenvolvimento do capitalismo moderno); a possibilidade de uma vida conjugal para monges e padres (extinguindo assim o voto de castidade); a dedicação integral e exclusiva aos preceitos prescritos na Bíblia; e a crença de que Jesus Cristo era o Deus vivo responsável pelo começo de uma nova era e de um novo concerto, maior que o próprio Deus épico do Velho Testamento hebraico.

Entretanto, a nova Igreja Católica vislumbrada por Lutero e seus 3 a correligionários não floresceu, ao contrário disso, os reformistas foram violentamente rechaçados pela cúria romana, e decidiram romper definitivamente com o Catolicismo. Lutero - uma das mentes mais engajadas no movimento de reforma religiosa propôs as mudanças que havia teorizado em suas 95 teses Figura 1: Martinho Lutero

sobre o poder e a eficácia das indulgências a uma parcela significativa da nobreza alemã que o acatou, promovendo-as junto com guerras sangrentas que foram desdobramentos dessas mudanças.

Dentre todos esses nomes, um se destaca e interessa diretamente a este trabalho: João Calvino (1509 - 1569). Diferentemente de Lutero, que fora padre católico e tinha profunda convicção em seus princípios religiosos, Calvino passou boa parte de sua vida leigo e, muito provavelmente, tornara-se religioso por conveniência da revolução protestante já em andamento quando ele surgiu no 
cenário intelectual franco-suíço como um humanista prodigioso. "Onde Lutero era grosseiro e inconsistente, Calvino era lógico e metódico. A teologia daquele era uma arma disparando para todos os lados; a deste, um rifle preciso de um atirador de elite" (MARSHALL, 2017, p.46) ${ }^{11}$.

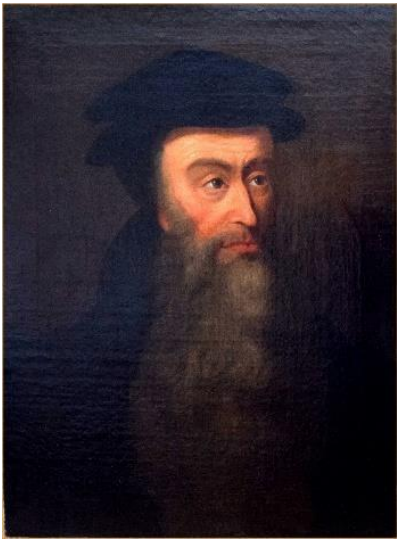

Figura 1: João Calvino

Conhecido principalmente por sua doutrina da eleição ou predestinação, na qual impera a máxima bíblica de que "Muitos são chamados, mas poucos escolhidos" (Mateus 22:14, BÍBLIA SAGRADA, 2000, p.759), Calvino acreditava que Deus concebia dois tipos de pessoa: aquelas que herdariam a "vida eterna" e aquelas que estariam condenadas à "eterna danação" (MCGRATH, 2004, p.62-3). Esse princípio de organização metafísica serviria, pois, como base para segmentos religiosos como os Metodistas, Batistas e os Presbiterianos estadunidenses (estes últimos estudados neste trabalho) reformularem parte da cosmovisão ocidental no que diz respeito a aspectos da conduta social e à maneira como Europa, Estados Unidos e, principalmente, América Latina se inseririam na cultura moderna decorrente do modo de produção capitalista a partir do final do século XIX.

\subsubsection{A política linguística na Reforma}

Até o século $\mathrm{XVI}$, na Europa, o latim era a língua predominante nos trabalhos religiosos da Igreja Católica, legitimando a hegemonia dessa instituição. Foi em latim que a alta intelectualidade católica realizou e difundiu sua interpretação da Bíblia no Ocidente medieval. Língua ascética e artificial, o latim eclesiástico buscava gerar a sensação de distância da vida cotidiana junto a uma sensação de universalidade transcendental, por isso, sua presença era restrita a espaços sociais relacionados a esses estados de espírito, como igrejas, conventos e universidades. Não sem razão, a participação dos fiéis europeus nos trabalhos religiosos católicos, até o século

\footnotetext{
${ }^{11}$ Fundador da Universidade de Genebra, em 1559, Calvino foi um profundo conhecedor das artes, ciências e filosofia, tendo-as como base de sua conturbada formação religiosa e de seus escritos sobre a religião reformada. Para ele, a educação teológica deveria se basear na imersão em estudos bíblicos, tradutológicos e no profundo domínio da retórica como prérequisito essencial para uma pregação evangélica efetiva, o que disciplinaria a conduta cristã, enrijecendo-a. Dentre suas obras teológicas, destacam-se as Institutas e Christianae religionis institutio, de 1536 (MCGRATH, 2004, p.53-64; MENDONÇA, 2008, p.57-63).
} 
XVII, consistia em assistir passivamente a missas e sermões em latim, geralmente, acomodados em naves ou capelas laterais que sequer Ihes davam acesso visual ao altar, obstruído por púlpitos e tribunas, não Ihes sendo "necessário ver o celebrante nem ouvir a voz do padre" (LEBRUN, 1986, p. 73-74).

A Reforma protestante e, na sequência, a Contrarreforma católica colaboraram para a afirmação das línguas europeias vernaculares na Idade Moderna (BURKE, 2004, p.49).

Dentre todas as propostas reformistas, a tradução da Bíblia e a substituição da liturgia em latim pelas línguas vernaculares são tidas como uma das mais importantes mudanças sociolinguísticas observadas nesse período. Em reação aos ritos católicos profundamente latinizados e, por isso mesmo, herméticos, os reformistas passaram a pregar a necessidade de o cristão ler a Bíblia traduzida para sua língua materna, ao invés de depender da intermediação dos padres e representantes do Catolicismo para ter acesso à palavra divina. Afinal, por mais que à época o latim fosse a língua franca de comunicação internacional, a grande maioria da população não o dominava e, em particular o eclesiástico, razão pela qual fez-se mister vulgarizar a comunicação religiosa por meio das línguas e dialetos europeus modernos (BURKE, 2004, p.51).

Como assinalado acima, a Igreja Católica não ficou atrás dos protestantes na questão linguística: desde o Concílio de Trento, realizado entre 1545 e 1563, promovia, gradativamente, algumas mudanças concernentes ao uso e à disseminação de textos religiosos em línguas vernaculares europeias, especialmente o francês. Sermões e leituras de partes do Evangelho, preces, missas, cânticos e orações passaram a ser traduzidos para línguas vulgares devido à necessidade de uma melhor interação entre fiéis e celebrantes dos ritos da igreja romana. Era já uma inclinação a uma cosmovisão neoclássica e iluminista que, no caso da França, promovia em larga escala a impressão de libretos bilíngues - latim e francês utilizados em ritos e festas religiosos (LEBRUN, 1986, p.75-77).

Com a grande demanda por novas interpretações do texto sagrado, incitadas tanto pela Reforma protestante quanto pela Contrarreforma católica, processou-se a cotidianização da religiosidade como estratégia para aproximar o Cristianismo dos princípios de humildade estipulados por Jesus Cristo, integrando assim populações 
camponesas ao Protestantismo, reorganizando a comunidade católica e retomando os conceitos de nação (Canaã) e nacionalidade presentes no Velho Testamento (BURKE, 2004, p.52; WEBER, 1996, p.120-122).

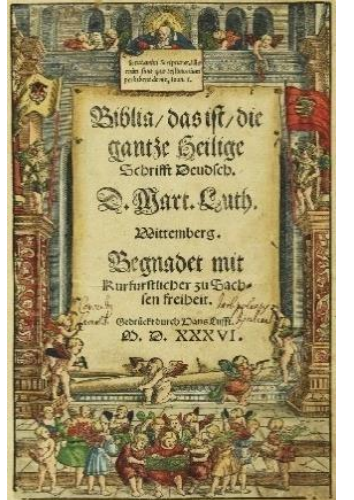

Figura 2: Bíblia

traduzida por Lutero em 1536

A Bíblia foi, portanto, na transição do Renascimento para a Idade Moderna, o principal meio de estandardização das línguas vernaculares europeias, sendo o primeiro e mais difundido livro a ser reproduzido pela imprensa tipográfica gutemberguiana. Nesse contexto, entre 1522 e 1534, o próprio padre reformista Martinho Lutero foi o primeiro a traduzi-la para um padrão regional do alemão, uma espécie de koiné utilizada na Alemanha central e oriental, baseando-se na versão latina das Sagradas Escrituras, a Vulgata12 (BURKE, 2004, p.103).

Parte da revolução linguística promovida pelas diversas traduções da Bíblia na Europa consistia na revolução das mentes e da cosmovisão de todos os povos que entravam em contato, pela primeira vez, com a cosmogonia judaico-cristã em toda sua extensão épica e lírica. A partir do momento em que os indivíduos liam e compreendiam o texto bíblico em línguas vernaculares, um outro mundo pronto para ser vivido, praticamente desconhecido da maioria até então, com início, meio e fim, se apresentava.

Por fim, a oposição por parte dos protestantes aos preceitos católicos, desde os conceitos éticos e morais mais abstratos até o meio linguístico utilizado para expressá-los, estava colocada na arena onde disputavam mentes e espaços sociais, glória, honra e poder em torno da questão religiosa universal. Como aludido acima, a Igreja Católica não permaneceu impassível diante da ameaça reformadora nascida dentro de seus quadros eclesiásticos na Alemanha, promovendo, também, reformas relacionadas a seu modus operandi cujos objetivos eram ampliar sua esfera de atuação. É, pois, problemático afirmar que somente a Reforma protestante foi responsável pela série de mudanças religiosas, políticas e sociais verificadas na

\footnotetext{
${ }^{12}$ A versão da Bíblia utilizada pela Igreja Católica, até então, era a chamada Vulgata, traduzida do hebreu e do grego para o latim, por São Jerônimo, no ano de 405. Suas primeiras edições impressas foram organizadas pela Universidade de Paris, no século XIII. Em 1546, o Concílio de Trento decretou a Vulgata como versão latina exclusiva da Bíblia e, em 1592, o Papa Clemente VIII reconheceu-a como único texto bíblico autorizado para uso em toda a Igreja Católica. (Fonte: https://pt.wikipedia.org/wiki/Biblia Acesso em 27 jun 2021)
} 
modernidade da Europa ocidental, afinal, nesse caso, "o fosso entre protestantes e católicos é menos profundo do que se poderia imaginar." (LEBRUN, 1986, p.104).

\subsection{A cultura protestante nos Estados Unidos}

Não estenderemos a explanação do que é e do que significa a cultura protestante no mundo ocidental desde a sua origem na Europa quinhentista, com Lutero e Calvino, visto que o tipo de protestantismo que chegou ao Brasil — pela via dos missionários estadunidenses - já era muito diferente daquele preconizado pelos líderes pioneiros da Reforma, pois já se compunha de diferentes famílias: luteranas, presbiterianas, metodistas, congregacionais, batistas etc.

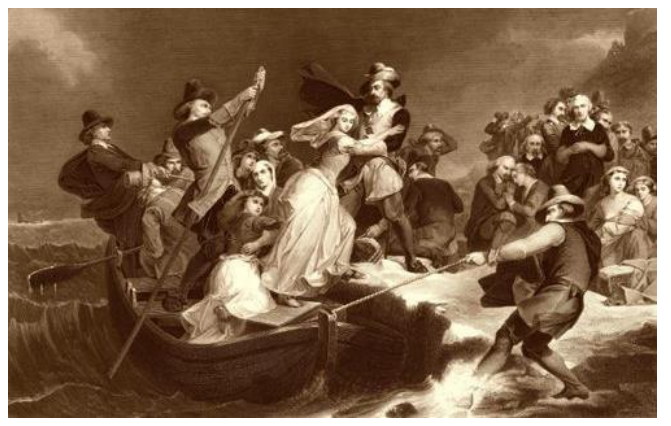

Figura 3: Landing of the Pilgrims on Plymouth, de Peter Rothermel, 1869
Os primeiros colonos puritanos chegaram da Inglaterra à América do Norte no início do século XVII. Apesar de a perseguição religiosa ter sido o principal motivo para essa imigração, o desalinhamento político-ideológico com o

governo inglês com e dificuldades econômicas conduziram levas de famílias às novas terras americanas. Eram indivíduos cultos, altamente escolarizados - sobretudo na Universidade de Cambridge - que em solo americano, fundaram o que viria a ser as Universidades de Harvard e Yale, em 1636 e 1701, respectivamente, além de se demonstrarem extremamente comprometidos com a religião protestante e com 0 bem-estar social de seus pares (ALGEO, 2001, p.08).

Movidos por um sentimento de diferenciação e superioridade, eles acreditavam que, a partir da ideia calvinista de predestinação, haviam sido escolhidos por Deus para habitarem uma nova terra prometida; um "admirável mundo novo" de onde a fé cristã reformada se espalharia aos quatro cantos do planeta. Outros grupos religiosos continuaram chegando até o início do século XVIII quando, finalmente, constituíram-se as chamadas "Treze colônias do norte". Em meados desse século já havia, nos Estados Unidos, congregacionalistas, luteranos, membros da Igreja reformada alemã, quakers, católicos, presbiterianos, anglicanos e 
calvinistas provenientes de diversas partes da Europa (CORRIGAN, 2004, p.167168).

Sobrepondo-se às características peculiares a cada ramo, o protestantismo estadunidense do século XIX obedecia a um sistema teológico mais ou menos uniforme denominado Avivamento ou Grande Despertamento, regido por dois princípios básicos: o da conversão que, pela regeneração entendida como novo nascimento, prometia a salvação individual; e o da devoção ao trabalho e à disciplina moral, que alimentariam a ideologia do progresso (MENDONÇA, 2005, p.51-52).

Do ponto de vista político, o protestantismo foi determinante para a consolidação da democracia estadunidense, pois a multiplicidade de seitas cristãs propiciava uma livre concorrência entre elas e, consequentemente, uma postura relativista e tolerante perante as diversas formas de expressão da fé cristã. Fosse o indivíduo protestante ou católico, o importante era que não negasse sua fé em alguma religião cristã para que, desse modo, integrasse a república como um cidadão exemplar, sendo que àqueles que não seguissem essa espécie de lei subliminar, estaria reservada a marginalidade (TOCQUEVILLE, 2010, p.472-473).

Apesar da separação entre religião e estado - promulgada pela Constituição estadunidense, em 1787 - estadistas e homens públicos estadunidenses se deixavam reger pelos princípios de filosofia e moral cristãs. As liberdades individuais eram respeitadas e estimuladas, porém, balizadas pela cosmovisão cristã que impedia às pessoas fazerem aquilo que lhes aprouvesse. N'alguns casos, por exemplo, o crédito bancário era associado, de forma anedótica, à frequência à igreja. É nesse sentido que o cristianismo foi de facto et de jure a primeira e principal instituição política estadunidense, revelando-o, desde sua colonização, como o país mais cristão e, ao mesmo tempo, mais capitalista do mundo (TOCQUEVILLE, 2010, p.472-473).

Dentro da ética protestante, a fé incondicional no Cristianismo, sobretudo no Cristianismo reformado, traz consigo a crença em valores da modernidade como o racionalismo cientificista, a noção de individualismo, o nacionalismo, o trabalho como vocação divina e a família (branca e heterossexual) como princípio formador da sociedade. Ademais, a crença convicta na palavra escrita impossibilitava ao protestante realizar acordos e tratados apenas por meio de conversas. A ética 
protestante previa o registro escrito, a crença convicta na lei e nos códigos de conduta, o que gerava um efeito de sentido de verdade inconteste, legitimando seus atos (ALGEO, 2001, p.09).

A ética protestante não se restringia a incentivar o trabalho incessante visando apenas o acúmulo de capital. Havia o desejo de ampliar seus espaços de atuação política e religiosa: levar a "Palavra do Senhor" aos quatro cantos do mundo como pretexto para colonizar territórios inóspitos e recolonizar outros que outrora foram dominados por potências imperialistas europeias:

[...] A profunda convicção alimentada pelos americanos de que sua nação tinha sido escolhida para uma missão universal foi nutrida e sustentada através da Guerra Civil, e recebeu um novo batismo de poder no período que se seguiu. Muitas forças se combinaram para exaltar o papel do "Destino Manifesto" na consciência americana. $A$ partir do darwinismo, os americanos tiveram a intuição de que pela seleção natural os Estados Unidos tinham se tornado uma nação superior destinada a dirigir os povos mais fracos. As filosofias idealistas enfatizavam a capacidade natural do homem e, interpretada a história em termos de progresso, tudo vinha favorecer a ideologia expansionista. Num período em que as nações europeias expandiam seus interesses imperialísticos pela África, Ásia, América Latina e Pacífico, os americanos se sentiram comissionados para estender as bênçãos da civilização cristã e o governo democrático. (OLMSTEAD, 1961, p.133 apud MENDONÇA, 2008, p.94 - Grifo nosso).

A criação do mito do "Destino Manifesto" incitava os cristãos estadunidenses a expandirem seus domínios como raça pretensamente superior às outras. Motes bíblicos como "Vós sois a luz do mundo; não se pode esconder uma cidade edificada sobre um monte" (BÍBLIA SAGRADA, 2000, p.739), serviram para legitimar o desejo estadunidense de tornar seu povo guardião da "receita correta" de organização social e portadores de uma suposta "verdadeira religião cristã". Por conseguinte, esses protestantes se viam como o povo escolhido por Deus para propagar os valores civilizadores de uma sociedade cristã, projetando, de antemão, o que viria a ser o imperialismo neocolonialista estadunidense do século $X X$ :

[...] Para o protestante americano, parecia bem claro que Deus o havia escolhido para ser, política e religiosamente, mestre da raça humana. [...] antes do fim do século XIX, os empreendimentos missionários haviam dado provas de invulgar importância, talvez 
inconsciente, de sua aliança com o imperialismo americano.

(OLMSTEAD, 1961, p.70-71, apud MENDONÇA, 2008, p.99).

Apesar do sistema teológico mais ou menos comum às diferentes igrejas, a laicização dos Estados Unidos levou ao modelo de "mercado aberto de missões". Sem o apoio exclusivo do poder, as igrejas tiveram que se reinventar e trilhar caminhos próprios para conquistar a adesão dos fiéis (CAVALCANTI, 2001, p.62).

Para realizarem semelhante empresa, os protestantes expandiram seu campo de atuação, partindo em missões a países da América Latina, a partir da segunda metade do século XIX. Desse modo, eles deram início a uma discreta campanha no Brasil, que passaria despercebida não fosse a relativa importância de algumas instituições por eles fundadas, dentre as quais, destacam-se aquelas relacionadas à educação formal, uma vez que parte do protestantismo estadunidense está ancorado em uma "inflexível fé na educação" (RAMALHO, 1975, p.79).

\subsection{O Catolicismo brasileiro}

Antes de apresentarmos a maneira como se deu a inserção dos protestantes no Brasil, com suas atividades religiosas e educacionais, vamos conhecer um pouco do contexto religioso brasileiro existente desde o princípio da colonização da América portuguesa, no século XVI. Esse contexto está diretamente ligado à Igreja Católica Apostólica Romana que foi instaurada como primeira religião do Brasil com a chegada definitiva dos portugueses a essa região. Daí em diante, trabalhou em parceria com a Coroa portuguesa vindo a remodelar-se por meio da Contrarreforma, movimento que promovia ajustes e mudanças nas práticas católicas, sobretudo, após o cataclismo promovido pelo protestantismo questionador de práticas católicas milenares. A própria "descoberta" do chamado "Novo Mundo" contribuiu para o questionamento dos dogmas católicos, pois era preciso adicionar essa novidade não prevista nas Sagradas Escrituras à cosmovisão cristã e, especificamente, à concepção de mundo católica.

Estruturalmente, a Igreja Católica no Brasil era demasiadamente complexa, às vezes, resvalando em julgamentos e condenações arbitrários, autoritarismo por 
parte de seus líderes e seguidores, ao mesmo tempo em que, por outro lado, agia como assessora da elite administrativa portuguesa no processo de colonização e aculturação de índios e colonos, legitimando, dos pontos de vista simbólico e ideológico, o modo escravagista, patriarcal e oligárquico como a metrópole lusitana produzia riquezas e conduzia o estado brasileiro.

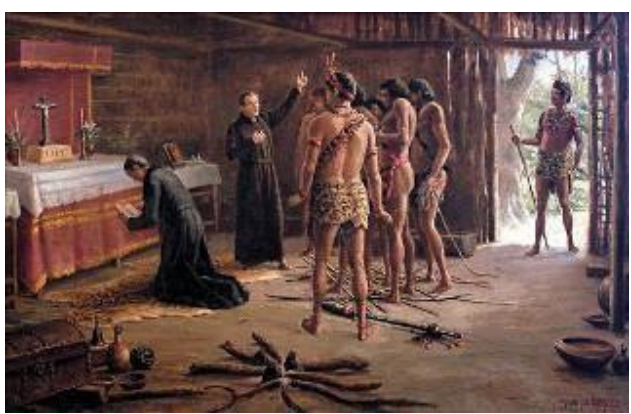

Figura 4: Anchieta e Nóbrega na cabana do Pindobuçu, Benedito Calixto (1920)
Sua complexidade está no fato de que, ao mesmo tempo em que opositores eram considerados hereges e punidos severamente por isso, toda sorte de raças e castas era aceita no culto católico brasileiro, via de regra, bastante

informal e supersticioso se comparado ao ritualismo protocolar demonstrado nos trabalhos religiosos católicos europeus. Picos de intolerância conviviam lado a lado com a mais permissiva tolerância. A falta de rigor ético e a corrupção também eram comuns entre os clérigos brasileiros que nesses quesitos se pareciam com os administradores públicos e privados coloniais (FREYRE, 2003; HOLANDA, 1995; RIBEIRO, 1995).

Acerca da relação da igreja com o estado, representantes do Catolicismo, não raramente, envolviam-se em polêmicas com a Corte. Devido ao chamado Padroado régio, ${ }^{13}$ o clero chegou a atuar como coadjuvante no processo de colonização brasileira, disputando com a Coroa o controle das finanças eclesiásticas. Nesse aspecto, um episódio significativo foi a expulsão compulsória de todos os jesuítas da Companhia de Jesus em meados do século XVIII, quando esses religiosos já haviam promovido a gramatização e difusão da língua geral, junto a suas práticas educativas de catequização entre grandes contingentes de índios Tupinambás. Ao se deparar com o recrudescimento da força política e ideológica dos jesuítas, a Coroa portuguesa não hesitou em extirpá-los imediatamente por meio de um decreto, mantendo assim o monopólio do poder no processo de implementação da língua portuguesa como idioma oficial em todo o território nacional, além de regular os costumes e hábitos das populações indígena, negro-africana, europeia e mestiça

13 "O Padroado régio implicava o direito às rendas eclesiásticas por parte da Coroa portuguesa. Rendas essas que provinham essencialmente dos dízimos. Cabia, portanto, à Coroa arrecadálos no Brasil. Nem sempre, porém, esses dízimos eram revertidos para a Igreja" (LIMA, 2014, p.48). 
objetivando com isso formar e consolidar, à sua maneira, a sociedade brasileira (MARIANI, 2004; RIBEIRO, 1995).

Não obstante alguns eventos como o supracitado, a importância estratégica da religião católica foi imprescindível para a formação do Brasil como maior estado católico da América Latina. Daí a constituição da unidade brasileira em torno de uma religião considerada única instituição simbólica que, ao ver de toda a sua população, até o começo do século XIX era incontestável. A partir desse arquétipo de nacionalidade foi possível combater um inimigo comum, a saber, o não católico (FREYRE, 2003, p.91-92).

Após o processo de independência política do Brasil, em 1822 - no qual o país continuou sendo uma monarquia - e com o empoderamento do império inglês e do republicanismo democrático dos Estados Unidos, a Igreja Católica se reformulou mais uma vez, mas não conseguiu conter os avanços de teorias políticas e cientificistas como o liberalismo, o racionalismo empiricista, o evolucionismo darwiniano, o positivismo etc. Assim como não conseguiu evitar que diversas denominações protestantes se instalassem no país e construíssem suas comunidades.

Diante da ameaça do enfraquecimento da influência espiritual da igreja romana pelo avanço das ideias liberais e do protestantismo, ao longo do século XIX, diferentes ordens religiosas católicas se instalaram no Brasil, motivadas pela "necessidade de fortalecer o prestígio da Santa Sé" (CORDEIRO, 2005, p.113). Deuse início ao movimento de "romanização" dos bispos reformadores e de "ultramontanismo" da ala conservadora da Igreja Católica na tentativa de reorientar o catolicismo popular pelas diretrizes romanas, em atitude claramente contrária às aspirações liberais que iam na direção de uma sociedade mais secularizada. Nesse contexto de resistência ressurgem as ordens católicas jesuíticas e aparecem as lazaristas e salesianas.

Apesar das investidas da Igreja Católica, as ideias liberais foram ganhando solidez à medida que a preocupação com a unificação do território - após as várias rebeliões no período das Regências, no bojo das questões escravistas e migratórias - cedia lugar para a formação da identidade nacional pautada por um projeto civilizatório formador do cidadão por meio da educação. Essas novidades já circulavam entre intelectuais ligados à incipiente burguesia citadina, sendo 
reforçadas pela presença e atuação de uma ala protestante (NOVAES, 2001, p.161204).

Ainda no império, e com uma lenta e gradual laicização do estado, a lgreja Católica foi se afastando do monopólio dos atos cívicos (registro civil, casamento, sepultamento etc), o que representou perda de poder político para legitimar a cidadania (SCHWARTZMAN, 1986, p.112). A conjuntura de laicização do estado e do projeto civilizatório em curso, aprofundados com a instauração da república, levou à corrida de abertura de colégios por diferentes confissões religiosas ${ }^{14}$, colocando lado a lado as de ordem católica e as de perfil protestante.

É nesse contexto sociopolítico que a educação - bandeira republicana (CARVALHO, 1990, p.32-33) - torna-se o foco de diferentes confissões religiosas, na "disputa pela formação das elites dirigentes do país" com a finalidade de difundir modelos culturais provenientes não apenas da Europa - como ocorrera durante os períodos colonial e imperial — mas também dos Estados Unidos (CORDEIRO, 2005, p.111; REIS FILHO, 1995, p.145).

\subsection{A inserção dos protestantes no Brasil no século $X I X$}

Desde a reforma pombalina, no século XVIII, que resultou na expulsão, do Brasil, dos jesuítas, as relações entre o estado brasileiro e a Igreja Católica se tornaram bastante conturbadas, chegando mesmo a alguns momentos de hostilidades. O estado, na figura da Coroa portuguesa, passou a controlar a igreja, combatendo a supremacia papal e deixando o Vaticano à mercê da situação religiosa brasileira. Esse movimento de controle, denominado Regalismo, além de submeter e enfraquecer a Igreja Católica no que se referia às decisões políticas mais importantes dentro de seu campo de atuação, acabou por se tornar um dos fatores facilitadores da entrada do Protestantismo no Brasil. Não obstante, o Catolicismo

14 Os jesuítas se dedicaram ao ensino no período colonial, atividade rompida com a sua expulsão em meados do século XVIII. Reingressando ao Brasil no segundo império instalaram o colégio de meninos em Itu (COLSATO, 2016, p.79-80). A propósito do ensino, também é digna de nota a contínua e tradicional atuação da ordem beneditina no Mosteiro de São Bento, polo de instrução da elite paulista. 
resistiu e continuou a existir com seus dogmas, ritos, variações e aversão à Reforma (RIBEIRO, 1973).

Além do Regalismo, outro fator crucial que contribuiu para que os protestantes ganhassem seus "vistos de entrada" no Brasil foram as forças políticas e econômicas do liberalismo inglês, a partir da abertura dos portos às nações amigas e do Tratado de aliança e amizade, ambos em 1810, que garantiam liberdade religiosa aos ingleses que se instalassem nesse país. Seduzidas pela ideologia do progresso, as elites locais, em momento da laicização do estado, recepcionaram os protestantes (e a Maçonaria) principais representantes do liberalismo social, político e econômico à época (MENDONÇA; VELASQUES FILHO, 1990).

O século XIX foi decisivo para a entrada definitiva do Protestantismo no Brasil. ${ }^{15}$ Pistas de natureza político-social levam à identificação de dois fluxos protestantes distintos que chegaram ao país numa perspectiva complementar: o protestantismo de imigração e o de missão. O primeiro está correlacionado à presença de ingleses da Igreja Anglicana; além de estadunidenses, suecos, dinamarqueses, escoceses, franceses e, principalmente, alemães da Igreja Luterana que começaram a chegar no Rio de Janeiro em 1822, logo depois da independência. O fluxo protestante imigrantista criou condições facilitadoras da inserção do movimento missionário no Brasil — por isso a complementaridade. Os imigrantes solicitavam, junto às autoridades brasileiras, garantias legais de liberdade religiosa que permitiam a difusão de missões religiosas não-católicas (MATOS, 2011, p. 812).

Entre os que integravam o primeiro fluxo, a literatura menciona os "confederados" estadunidenses que, na fuga da Guerra Civil de 1865, se dirigiram em parte para o interior de São Paulo, estabelecendo-se em Santa Bárbara $d^{\prime}$ Oeste $^{16}$. Provenientes principalmente dos estados do sul dos Estados Unidos,

15 Os protestantes já haviam estado no Brasil no período colonial. Em 1555, Huguenotes franceses liderados por Nicolas Durand de Villegaignon desembarcaram na Baía de Guanabara, Rio de Janeiro, iniciando um projeto de colonização chamado "França Antártica", que duraria efêmeros doze anos até que fossem expulsos pelos portugueses em 1567. Em 1621, chegaram a Salvador as primeiras levas de calvinistas holandeses lideradas por João Maurício de Nassau Siegen, que viriam a fundar as cidades de Recife e Olinda, em 1630. Essa ocupação protestante também durou muito pouco tempo, pois os holandeses foram expulsos do Brasil, pelos portugueses, em 1654 (MATOS, 2011, p.4-6).

16 O Brasil recebeu cerca de duas mil pessoas que fundaram colônias nas províncias de Pará, Bahia, Espírito Santo, Rio de Janeiro, São Paulo e Paraná (RIBEIRO, 1973, p.67). 
esses imigrantes fundaram a cidade de Americana e presbiterianos, também sulistas, se concentraram em Campinas. Nesse movimento migratório, metodistas e batistas $^{17}$ também adentraram o território brasileiro. Apesar de não terem projetado uma igreja com finalidades civilizatórias embutidas na ideia da propagação da fé, esses imigrantes, que se limitavam à prática do culto, formaram a primeira camada protestante no Brasil, implantando um novo estilo de vida na região (MATOS, 2011, p. 8-9).

O segundo fluxo diz respeito ao protestantismo de missão ou conversão. Iniciado com os metodistas ${ }^{18}$, em 1836, o movimento se adensou a partir da segunda metade do século com a entrada de presbiterianos, episcopais, congregacionais ${ }^{19}$ e luteranos, filiados ao protestantismo religioso estadunidense, os quais se instalaram no Brasil como "arautos do liberalismo, do pragmatismo e do progresso", promotores da educação voltada para a ciência e para a técnica (CORDEIRO, 2005, p.116). Os primeiros missionários estadunidenses a adentrarem no país eram nortistas, mas em meados do século XIX o protestantismo brasileiro foi hidratado por sulistas. Nessa composição, os pastores Edward Lane e George N. Morton, da Igreja Presbiteriana do Sul ${ }^{20}$, foram encaminhados para o Brasil em 1868.

Para divulgar e propagar a fé protestante distribuíam-se bíblias e hinários gratuitamente por extensas regiões do país, sobretudo, nos rincões mais afastados dos centros urbanos. Esses instrumentos ideológicos funcionavam como pilares de sustentação do pensamento reformista e principal arma para a conversão de novos adeptos. Em um ambiente de baixo nível de instrução, a distribuição de bíblias e hinários era a riqueza simbólica à disposição dos protestantes para atingir o

\footnotetext{
17 Os batistas priorizavam a evangelização em lugar da educação (CAVALCANTI, 2001, p.83). Em 1882 o batista William Bagby apresentou proposta de educação como instrumento de evangelização (CALVANI, 2009, p.61-62; CRABTREE, 1962, p.38, 135, 187). Para os batistas a educação não é uma preocupação central, mas apenas um apêndice da missão.

18 A metodista Martha Watts, com ajuda da família Moraes de Barros, fundou o Colégio Piracicabano em 1881. Watts teria sido hospedada por Manoel Moraes de Barros, irmão de Prudente de Moraes. Esse colégio, em que estudaram os Moraes, foi a "célula-mater da reforma da instrução pública de São Paulo" (MESQUIDA, 1994, p.67).

${ }^{19}$ Os congregacionistas se ligavam ao missionário e médico escocês Robert Reid Kalley (18091888) responsável pela evangelização e conversão de alguns integrantes da nobreza de Petrópolis, o que the rendeu ameaças e perseguições por seus opositores (SANTOS, 2010, p.20-21).

20 A Igreja Metodista do Sul também iniciou suas atividades no Brasil nesse período, com o envio do pastor Junius E. Newman. Já os batistas do sul demoraram mais uma década para se deslocarem para o Brasil (CALVANI, 2009, p.55).
} 
imaginário popular. Como forma de conquistar adeptos, era 0 ato performativo do chamamento. Para os grupos que tinham uma relativa educação formal, essa doação os legitimava como escolhidos; para os demais, sinalizava a aceitação de não terem sido escolhidos. Se pensarmos na dádiva como fato simbólico e que, no folclore germânico, o presente se transforma em veneno (MAUSS, 2013, p.185), podemos pensar, no caso do Brasil que tinha um baixíssimo índice de alfabetizados (ver adiante), na distribuição de bíblias e hinários como uma chave para uma porta sem fechadura ${ }^{21}$.

Entre os pioneiros nessa atividade, destaca-se a dupla de missionários metodistas Daniel Parish Kidder e Justin Spaulding que desempenhou uma importante função de evangelização durante os anos de 1837 a 1841, distribuindo bíblias e evangelizando em diversas cidades brasileiras. Em 1838, Kidder conseguiu estabelecer relações com alguns membros da elite paulista, embora de maneira tacanha e um tanto efêmera. Outro missionário que se destacou no cenário político e intelectual do Segundo Império foi o pastor presbiteriano James Cooley Fletcher que estabeleceu amizade com o imperador D. Pedro II e influenciou pessoas de destaque na sociedade brasileira. De origem calvinista e filho de banqueiro, Fletcher integrava atividades científicas, comerciais e políticas ao seu ministério, sendo responsável por promover exposições industriais no Rio de Janeiro. Foi correspondente do Instituto Histórico e Geográfico Brasileiro (IHGB); promovia os métodos educacionais estadunidenses e apresentava os Estados Unidos como modelo de progresso cultural e econômico para o Brasil (SANTOS, 2010, p.17-18).

A atmosfera sociopolítica propiciada pelos intelectuais republicanos em torno de 1870, que afrouxou a resistência à liberdade de crença e, com isso, favoreceu a entrada dos missionários, encontrava alinhamento com o projeto expansionista estadunidense:

Era o imperialismo em sua forma cultural que lançava seus tentáculos pelo mundo civilizado, e plantava, pela via religiosa, as raízes de uma civilização que se considerava o exemplo de um sistema político democrático e que queria expandir-se como nação e, por meio dessa expansão, divulgar e implantar seu modo de vida. (ALMEIDA, 2007, p.329)

${ }^{21}$ Marilza de Oliveira (Comunicação pessoal). 
Apesar da diferenciação entre os dois fluxos, não se pode dissociar um do outro, pois os imigrantes são a porta de acesso para os missionários. Foi com a imigração populacional que as igrejas protestantes sulistas passaram a enviar missionários para o Brasil (CALVANI, 2009, p.59). Foi por meio dos imigrantes estadunidenses que os missionários aprenderam as diferenças culturais e regionais e ganharam o domínio da língua portuguesa que lhes permitiu "desenvolver uma estratégia de expansão no território nacional" (CAVALCANTI, 2001, p.82).

A missão protestante no Brasil foi um investimento das igrejas setentrionais e meridionais dos Estados Unidos. A implantação do Presbiterianismo, por exemplo, se deu por meio de duas denominações estadunidenses: a Igreja Presbiteriana do Norte (PCUSA) cuja agência missionária era a Junta de Missões Estrangeiras, sediada em Nova lorque; e a Igreja Presbiteriana do Sul (PCUS), cujo Comitê de missões estrangeiras tinha sede em Nashville, Tennessee. Dividida já no solo que Ihe deu origem, em função das conjunturas socioeconômicas e culturais entre o norte e o sul daquela nação ${ }^{22}$, a missão protestante traz em sua bagagem diferenças estruturais:

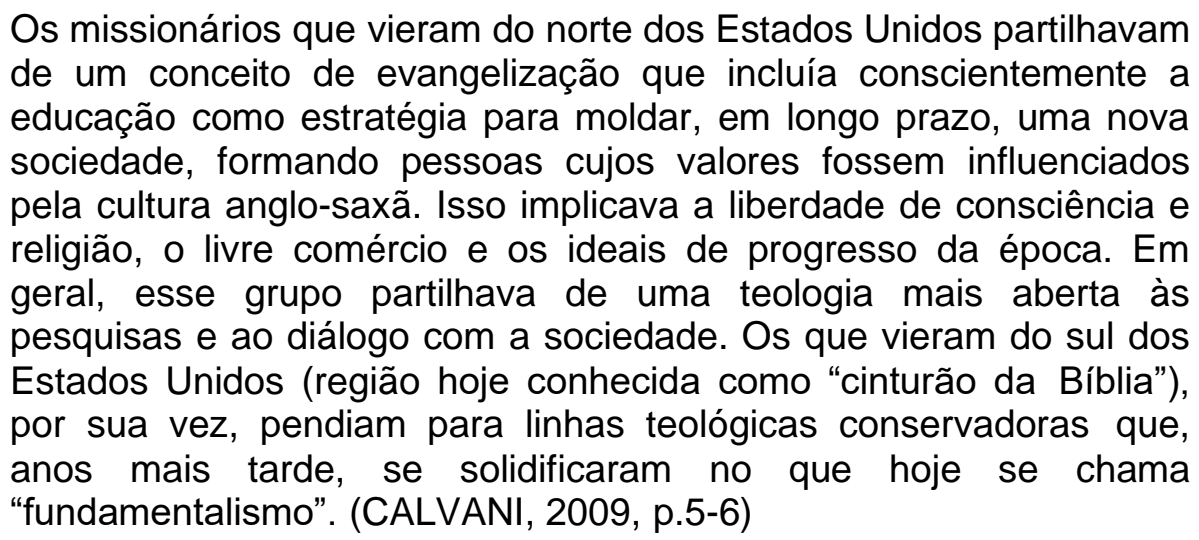

A diferença cultural entre norte e sul é visivelmente marcada no âmbito da educação. Orientado pelo pragmatismo, o norte privilegiava a preparação profissional para atender as demandas do país. Valorizando a livre-iniciativa, a

\footnotetext{
22 O norte dos Estados Unidos era industrializado, atendia as demandas de uma classe média emergente, abrigava várias universidades e era favorável à abolição da escravatura. O sul tinha sua economia ancorada nos latifúndios, era dependente da mão de obra escrava e era considerado atrasado também do ponto de vista cultural. O rio Ohio é indicado por Tocqueville como a fronteira entre o sul de economia escravagista, homem ocioso e sociedade adormecida e o norte de economia industrializada, homem trabalhador e sociedade rica (CALVANI, 2009, p.57-59).
} 
formação religiosa e a constituição da cidadania. A lgreja Protestante do Norte tinha em sua agenda perseguir os ideais do Reino de Deus na Terra, o que seria feito por meio do suporte ao projeto de uma nação republicana. Por esse viés, o protestantismo foi amplamente recepcionado pela elite brasileira que pretendia se aliar aos crescimentos econômicos estadunidense e inglês.

A partir da segunda década do século $X X$, as igrejas protestantes brasileiras ganharam autonomia financeira e independência política em relação às matrizes estadunidenses, mas se deixaram enredar pelos conflitos de poder nas cúpulas eclesiásticas e nos colégios e, como se não bastasse, gradativamente foram ganhando uma expressão mais conservadora com a penetração dos missionários fundamentalistas do sul dos Estados Unidos. Os sulistas entendiam que a "escravidão era uma instituição ordenada diretamente por Deus e legitimada pelas Escrituras", consideravam a si mesmos como os verdadeiros "guardiões da pureza bíblica" (CALVANI, 2009, p.59) e viam a escola tão somente como estratégia de alfabetização para a leitura bíblica. Essa vertente protestante investia exclusivamente no proselitismo, alegando que as iniciativas sociais e educacionais eram inócuas, porque não levavam à conversão evangélica e que se devia passivamente aguardar a vinda de Jesus Cristo à terra. Essa concepção levou esses protestantes a privilegiar as frentes missionárias e a construção de igrejas, o que fez arrefecer os investimentos na área educacional e estancar o processo de construção de colégios protestantes. ${ }^{23}$

Apesar da tolerância à presença protestante pela elite brasileira, a consolidação da missão presbiteriana foi bastante tumultuada. Um dos grandes problemas enfrentados foi "o choque entre a racionalidade da fé anglo-saxônica e do (sic) misticismo latino-americano no que se refere à experiência do sagrado" (CAVALCANTI, 2001, p.76). A disciplina, o pragmatismo e a racionalidade dos presbiterianos não combinavam com a religiosidade supersticiosa e com 0 misticismo autóctone dos católicos, fator estruturante da elite paulista que se pretendia conquistar, de sorte que já em seu primeiro Sínodo de 1879 provocou uma clivagem no protestantismo de fundo presbiteriano, culminando na criação da Igreja Evangélica Brasileira.

\footnotetext{
${ }^{23} \mathrm{~A}$ igreja católica também foi acometida pelo conservadorismo no início do século $X X$ e, com a instalação da república, na qual revigorava a separação entre estado e igreja, a questão educacional perdeu importância política e deixou, assim, de receber investimentos da igreja (SCHWARTZMAN, 1986, p.118).
} 
Outro problema com o qual os protestantes, de um modo geral, tiveram de se ver foi a onda nacionalista que tomou conta da sociedade brasileira, de modo que os templos evangélicos foram atacados pela imprensa local. Nessa conjuntura, os pastores nacionais, liderados por Eduardo Carlos Pereira, passaram a refutar a liderança estrangeira da Igreja Presbiteriana e, no Sínodo de 1903, procuraram afastar a Maçonaria do meio protestante e assumir o controle do seminário, do que resultou a criação da Igreja Presbiteriana Independente 24 .

Como saldo dessas pressões, teve-se a perda da identidade anglo-saxônica e, com ela, o afastamento dos líderes flexíveis e menos dogmáticos em sua forma de pensar. O resultado é que o sistema representativo e democrático da administração da lgreja se transformou de tal maneira que a sua organização se centralizou nos clérigos de formação mais ortodoxa, criando-se, assim, a lgreja Presbiteriana do Brasil.

\subsection{A missão presbiteriana: divisões de lá e cá}

A literatura historiográfica do protestantismo no Brasil tem colocado a educação como uma estratégia da "empresa" missionária dos presbiterianos (HACK, 2000; MENDONÇA, 2008; JARDILINO, LIMA; PROENÇA LOPES, 2011), pontuada na necessidade de criação de escolas "para assegurar o futuro da lgreja evangélica no Brasil”, proposta por seus líderes em 1867 (HACK, 2000, p.59). Buscava-se a propagação do evangelho - em particular entre as classes superiores - para melhorar "a cultura e o progresso da nação", "exercer melhor influência na sociedade" e "preparar líderes para a igreja" (PIERSON apud MATOS, 1999, p.4).

A estratégia expansionista adotada pelos presbiterianos ${ }^{25}$ foi a criação de uma rede educacional que se estendia largamente pelo território nacional e a construção de seminários ${ }^{26}$ para a formação teológica dos clérigos nacionais. Além

24 Em 1907 foi fundado um seminário em São Paulo; em 1908 foi instalado o Sínodo, inicialmente com três presbitérios. Por esse período, essa vertente que não tinha qualquer vinculação com instituições estrangeiras já havia construído 56 igrejas (SANTOS, 2010, p.27) 25 A expansão pelo território nacional foi estratégia dos presbiterianos e dos batistas. Os metodistas e os congregacionais se concentraram na região centro-sul e os luteranos se restringiram à região sul (LÉONARD, 1981; CAVALCANTI, 2001).

${ }^{26}$ Os presbiterianos criaram seminários para a formação de clérigos brasileiros no Rio de Janeiro, Vitória e Recife (CAVALCANTI, 2001, p.83). 
da edificação de escolas, os presbiterianos atuaram na divulgação de suas atividades por meio da imprensa de circulação local e nacional, e por meio da distribuição de bíblias, panfletos e livros doutrinários, como já foi dito anteriormente.

A primeira missão presbiteriana no Brasil data de 1859, com a vinda do reverendo Ashbel Green Simonton ao Rio de Janeiro. A partir desse momento, criaram-se igrejas presbiterianas no Rio de Janeiro (1862), São Paulo (1865) e Brotas - SP (1865), além da colocação em circulação do jornal Imprensa Evangélica (1864-1892) e da formação do Seminário ${ }^{27}$ do Rio de Janeiro (1867). Na sequência, São Paulo recepcionou a Escola Americana (1870) e os presbiterianos criaram os Presbitérios de Campinas e de Minas Gerais, ambos em 1886, e o de Recife em 1888, ano que marca também o Sínodo do Brasil (1888), que acarretou em autonomia eclesiástica à Igreja Presbiteriana do Brasil (MATOS, 1999, p.9). Os presbiterianos criam suas primeiras escolas justamente na década da cisão entre intelectuais, ou seja, no período em que começam a surgir grupos de intelectuais que não pertenciam à classe política (ALONSO, 2002, p.87-88), fator relevante para a discussão sobre a norma linguística selecionada pela comunidade protestante. Dentro do esquema estrutural da luta pelo controle social entre aqueles que faziam parte do establishment local - o grupo que tinha acesso a instituições políticas formais - e os outsiders, não havia muita margem de escolha para os novos forasteiros ${ }^{28}$. A construção do sentido social do poder se faria sentir na escolha da norma linguística a ser adotada como modelo a ser seguido pela comunidade protestante.

Com o advento da República, os missionários presbiterianos do norte avançaram enormemente até a década de 1910. Invertendo a ordem missionária, que tinha por prioridade a expansão da igreja protestante pela conversão, esses presbiterianos passaram a focar na necessidade de "educar para civilizar", dedicando-se, portanto, à atividade educacional, caminho que os aproximava do projeto civilizatório das elites brasileiras. É por esse viés que os presbiterianos conquistaram aliados entre os membros dessa elite, como as famílias do Marquês do Paraná, do Barão de Antonina e dos Souza Barros (CAVALCANTI, 2001, p.75),

27 Em 1865 ordena-se o primeiro pastor evangélico brasileiro, José Manoel da Conceição (LÉONARD, 1981, p.144-145).

${ }^{28}$ Remetemos a Elias e Scotson (2000) a discussão sobre os esquemas estruturais do controle social. 
alianças essas que se concentravam mais na busca de uma educação moderna do que na conversão religiosa da elite dominante.

\title{
1.6. A educação formal protestante no Brasil
}

Naturalmente, as escolas protestantes não avançaram sem embaraço. A igreja católica que, com a ruptura da relação estado-igreja, havia perdido o domínio do regramento da vida civil, buscava a qualquer custo ampliar o seu campo de atuação, ao menos, no mercado educacional. Para monopolizar esse mercado, os padres católicos ${ }^{29}$ envidavam todos os esforços para desconstruir as propostas do oponente. Em geral cravavam suas críticas no modernismo do programa educacional protestante que se realizava sem latim, sem catecismo e com excesso de esportes ${ }^{30}$. Além disso, as campanhas contrárias às escolas protestantes feitas pelos padres procuravam difamar a imagem do pastor, visto como um elemento autóctone, sem o respaldo de uma formação tradicional, legendária ou por ingleses sem escrúpulos que jogavam, bebiam e tinham vida sexual ativa:

\begin{abstract}
Estava dando resultados a terrível campanha que lhe moviam os padres do Arnaldo e do Claret. Os alunos escasseavam diante da propaganda feita pelos reverendos contra o nosso aprendizado sem latim, com futebol demais e oferecendo os perigos de ser ministrado por protestantes. De mais a mais, a casa desfalcara-se das figuras legendárias da primeira hora e procedia sua troca por elementos autóctones ou então por uns ingleses encanacados de Morro Velho avacalhados por uma longa convivência nacional - já jogando no bicho, bebendo cachaça e comendo negra. (NAVA, 2000, p.190)
\end{abstract}

Não obstante as celeumas e desconfianças, a escola protestante resistiu às investidas e adentrou o novo século legitimamente com o apoio do novo regime do governo. É que o governo paulista convida - salientemos o discurso de chamamento - o diretor Lane para auxiliar na estruturação da Escola Complementar e este

\footnotetext{
29 As críticas eram feitas na imprensa local ou em cartas pastorais nas quais os bispos exortavam os católicos a afastarem seus filhos dos colégios protestantes (NAVA, 2000, p.192). 30 Outra inovação protestante que despertou oposição nos círculos católicos foi a mistura de crianças de ambos os sexos na mesma sala de aula, alegando uma "educação promíscua", como ocorreu na Escola Americana (presbiteriana) de Lages e no Porto Alegre College [metodista]. (TAPIA, 2007, p.4).
} 
apresenta as pedagogas americanas que passam a atuar na Escola-Modelo ${ }^{31}$ (RIBEIRO, 2010, p.19)

Particularmente importante foi a função da escola protestante como um espaço social distinto e distintivo, à medida em que colaborava para o desenvolvimento cultural, social e econômico de um estado como São Paulo. A contribuição dos missionários protestantes advinha da ancoragem em textos escritos de seu culto, doutrina e hinos, que exigiam, por sua vez, o adestramento às práticas de leitura. Por esse viés, os protestantes ingressariam na luta contra o analfabetismo que grassava a sociedade brasileira.

O discurso da atuação distintiva da prática educativa usado para fins propagandísticos da atuação dos protestantes no projeto de civilização da nação brasileira tinha como meta a ser alcançada a ampliação do quadro de adeptos ao protestantismo. Nesse sentido, a educação era o instrumento por meio do qual se pretendia entrar na disputa da hegemonia ideológico-cultural da sociedade brasileira pela introdução de novos modelos culturais (CORDEIRO, 2005, p.110). Os missionários pretendiam atuar na transformação de mentalidade, ou seja, na formação de um ethos protestante voltado ao processo civilizatório com reorientação para o estilo de vida estadunidense - o American Way of Life - isto é, para o modelo burguês vitoriano que correlaciona a ética do trabalho à ideologia do progresso (MENDONÇA, 2008, p.144-167). Por outro lado, a inter-relação entre evangelização e civilização do protestantismo estadunidense impediu o diálogo com a cultura local. A contraparte linguística desse asseptismo moral e cultural está, a nosso ver, no descarte do vernáculo brasileiro (PVB), o que não seria uma novidade, pois no processo de construção do sentido social do poder de que faziam parte as camadas sociais privilegiadas - sejam os estabelecidos sejam os outsiders - o vernáculo era uma carta fora do baralho (OLIVEIRA, 2021).

A propósito do asseptismo, convém lembrar que colonizadores portugueses quinhentistas aculturaram índios e negros africanos e, de maneira muito parecida guardadas as devidas proporções — os missionários estadunidenses da igreja presbiteriana, ao chegarem no Brasil, consideraram a população local como amorais

${ }^{31}$ A abrangência das escolas normais e seus métodos de ensino serviu de modelo, inclusive, para outras escolas de outros estados brasileiros além de São Paulo, nos níveis da educação infantil (jardim de infância) e primário (MARCíLIO, 2005). 
e incivilizados. Trazendo consigo a crença convicta do Destino Manifesto, os protestantes tinham por projeto a correção da rota religiosa para educar a população brasileira dentro dos valores estadunidenses, conformando a nação brasileira como uma sucursal - à "Grande América", como observa Horace Lane ${ }^{32}$ :

O povo americano, embora esteja aguçadamente animado com a crescente importância do Brasil como ponto de referência comercial e político, parece ignorar o fato essencial de que esta nação deve ser educada nos ideais americanos para que, desse modo, se identifique com a Grande América. Os padrões de vida devem ser elevados, concepções errôneas de liberdade, autonomia e práticas cristãs devem ser corrigidas. O Cristianismo Protestante, entendido de um ponto de vista puramente político, é indispensável à república [...] Não é certo dizer que a massa populacional no Brasil é imoral, mas sim amoral - despossuída de uma percepção moral clara, segundo a nossa visão de moralidade - sem violar viciosamente ou frouxamente padrões éticos estabelecidos ela simplesmente faz o que seus guias espirituais têm feito por séculos. ${ }^{33}$

Os protestantes criticavam a elite oligárquica brasileira pelo fato de que esta não explorava o potencial industrial e econômico da população por meio da instrução e do acesso à educação formal. Até meados do século XIX, o Brasil só havia se destacado como grande potência mercantilista na produção e exportação de monoculturas como o açúcar e o café, mas ainda não havia se desenvolvido industrialmente. Daí o interesse dos missionários presbiterianos, de um modo geral, e dos educadores do Mackenzie, especificamente, em fomentar os métodos de educação estadunidense no Brasil (GOMES, 2001, p.161-171).

Os presbiterianos que fundaram o Mackenzie acreditavam numa ideologia baseada em princípios calvinistas de pureza moral e salvação individual, somada a um discurso liberal-republicano calcado em princípios democráticos e individualistas

\footnotetext{
32 De origem estadunidense (New England), Horace Manley Lane exerceu a medicina em Smithfield, Missouri. Foi presidente da Sociedade Médica do Condado de Jasper (1881 - 1882) e secretário da Sociedade Médica do Sudoeste do Missouri (1883 - 1884). (MATOS, 2004, p.104-105)

33 Tradução livre de: "The American people, while keenly alive to the growing importance of Brazil from a commercial and political standpoint, seem to ignore the essencial fact that the nation must be educated in American ideals in order to become identifield with Greater America. The standards of life must be raised, erroneus conceptions of liberty, self-government and Christianity must be corrected. Protestant Christianity considered from a purely political standpoint, is indispensible to the Republic [...] It is not safe to say that the masses in Brazil are immoral, but rather ammoral - without clear moral perception, according to our view of morals - not viciously or loosely violating established standards of ethics, but simply doing what their spiritual guides have done for centuries. "(MACKENZIE COLLEGE, 1909, p.3-4.)
} 
propalados nos Estados Unidos desde a sua independência política. Era o pensamento capitalista par excellence. Em contrapartida, não houve, por parte desses missionários, uma tentativa de ajustamento à cultura local já existente que contribuísse efetivamente para o estreitamento das relações entre protestantes e brasileiros como fizera - ou deixara-se fazer - o catolicismo em alguns pontos de sincretismo com as culturas cabocla, caipira, indígena e negro-africana:

O protestantismo que chegou ao Brasil jamais se identificou com a cultura brasileira. Continua sendo um protestantismo norteamericano com suas matrizes denominacionais e dependência teológica. Por isso, prefiro falar em 'protestantismo no Brasil' e não em protestantismo brasileiro. (MENDONÇA, 2005, p.51)

Além disso, quando as primeiras missões protestantes chegaram ao Brasil, a grande maioria da população - em torno de $90 \%$ - era analfabeta, o que dificultava muito o trabalho dos missionários que tinham como pressuposto básico de evangelização a leitura da Bíblia ${ }^{34}$. Este, ao que parece, foi um ponto fulcral que colocou o protestantismo em desvantagem, se comparado ao Catolicismo que exigia pouca leitura da Bíblia em seu culto, prosperando independentemente do grau de instrução de seus fiéis:

A carência de instrução [...] era um notável empecilho ao aprendizado da doutrina protestante, todo ele calcado na leitura da Bíblia, livros, revistas e jornais que logo começaram a ser publicados por iniciativa das missões. O culto protestante, especialmente como foi introduzido aqui, é, ao contrário do católico, essencialmente simbólico e ritualizado, caracteristicamente informal e discursivo. $\mathrm{O}$ informal supõe improvisação (que requer atenção e certa vivacidade mental), e o discursivo uma progressiva aquisição de vocabulário para entender a prédica do pastor. Além disso, o cântico dos hinos sagrados exige leitura relativamente rápida, embora a memorização possa ser largamente usada. De qualquer modo, o livro e o discurso estão sempre presentes na prática religiosa protestante. Daí não ser difícil concluir que a evolução do protestantismo dependia, em

\footnotetext{
34 "Os primeiros dados gerais sobre instrução no Brasil mostram enormes carências nessa área. Em 1872, entre os escravos, o índice de analfabetos atingia 99,9\% e entre a população livre aproximadamente $80 \%$, subindo para mais de $86 \%$ quando consideramos as mulheres. Mesmo descontando-se o fato de que os percentuais se referem à população total [estimada nesse recenseamento em 4,6 milhões], sem excluir crianças nos primeiros anos de vida, eles são bastante elevados. Apurou-se ainda que só $16,8 \%$ da população entre 6 e 15 anos frequentavam escolas. Havia apenas 12 mil alunos matriculados em colégios secundários. Entretanto, calcula-se que chegava a 8.000 o número de pessoas com educação superior no país. Um abismo separava, pois, a elite letrada da grande massa de analfabetos e gente com educação rudimentar" (FAUSTO, 1994, p.237).
} 
grande dose, da alfabetização de seus adeptos atuais, e em potencial da criança. (MENDONÇA, 2005, p.148 - grifo do autor)

A dificuldade de aderência do presbiterianismo no Brasil também deve ser creditada à conjuntura política e à suposta modernidade das religiões reformadas. $\mathrm{A}$ imigração dos protestantes os colocava exclusivamente na esfera da vida privada, visto que legalmente só a esse âmbito fora permitida sua participação na vida social brasileira - o Brasil ganhou o estatuto de Estado laico somente a partir da Constituição de $1891 .{ }^{35}$ Esferas pública e privada já eram dominadas pelo Catolicismo desde que os portugueses iniciaram a colonização do Brasil no século $\mathrm{XVI}$, por isso os presbiterianos sentiram dificuldades de se assentarem no Brasil. Aos protestantes restava então, respeitar a legislação brasileira como indício de modernidade republicana (uma de suas principais características) para serem relegados a um segundo plano:

[...] Paradoxalmente, nisso está a força do protestantismo. Força enquanto se apresenta como religião especificamente moderna, pois respeita a liberdade de consciência; fraqueza, que justamente por ser moderna precisa deixar a esfera pública para refugiar-se na esfera privada. [...]. ou seja, o protestantismo brasileiro tornou-se "invisível" ou um "ponto morto", não porque não fosse suficientemente moderno ou porque carregasse em si as diluições teológicas da América, mas justamente porque foi uma religião moderna. (FERREIRA, 2010, p.107)

Assim, pode-se considerar que 0 aparente insucesso das missões protestantes no Brasil se deveu menos à hegemonia da religião católica e a toda a cultura monárquico-colonial herdada de Portugal, e mais à própria cosmovisão dos missionários estadunidenses que demonstravam dificuldade de adaptação cultural às condições adversas com as quais se depararam aqui. Ademais, o alto nível intelectual exigido para integrar o grupo dos protestantes comprometeu, em parte, o

35 "Art. 115. A Constituição garante a inviolabilidade dos direitos concernentes a liberdade, segurança individual e propriedade, nos seguintes termos:

$\S 20$. E' livre o exercício de qualquer religião, desde que não offenda a moral ou a paz publica; Art 129. A inviolabilidade dos direitos relativos á liberdade, segurança individual e de propriedade, é garantida pela presente Constituição aos nacionaes e estrangeiros residentes no Estado, nos termos seguintes:

§ 3o. O Estado não adopta nem subvenciona religião alguma." (CONSTITUIÇÃO, 1896, p.34). 
projeto neocolonizador dos missionários presbiterianos do norte (MENDONÇA, 2005, p.53-55).

\title{
1.7. A educação presbiteriana em São Paulo
}

A segunda metade do século XIX marca a grande mudança pela qual, em pouco tempo, passou a província de São Paulo. O monótono planalto de Piratininga - que desde a chegada dos padres jesuítas servia basicamente como ponto de encontro e passagem de tropeiros e viajantes - ganhava a partir de então contornos urbanos que se delineariam rapidamente até surgirem os primeiros esboços de um grande centro populacional e administrativo. Entre esses contornos urbanos de "edifícios modestos e tristes", surgia na década de 1870 a Escola Americana:

\begin{abstract}
Nesta hora, e no meio desta ruidosa festa; entre tantas luzes e flores, o meu espirito se concentra e evoca uma época bem longínqua de minha vida, há quarenta annos passados, em que surge na minha imaginação esta querida cidade onde nasci; sem electricidade e telephones, sem tramways e viaductos; sem asphalto e jardins; sem gramophones e jazz-bands; e lembro-me do São Paulo de então, cidade das rotulas e da edificação colonial com seus prolongados beiraes; a clássica garoa e noites de neblina; os carros de bois e tropas pelas ruas mal calçadas; os edifícios modestos e tristes; e em um recanto da cidade, na esquina da rua de São João, hoje avenida sumptuosa, e então rua estreita, e a rua Ipiranga; no mesmo prédio ainda alli existente, nessa época ainda menor do que hoje, levantava-se a Escola Americana, povoada de meninos, que hoje são velhos, onde íamos procurar as primeiras noções do saber. (STEIDEL, 1923, p.01)
\end{abstract}

Influenciados pela grande quantidade de imigrantes protestantes de origem alemã e inglesa que chegavam àquela região, em 1863, os reverendos presbiterianos Ashbel Green Simonton, Alexander Blackford e George Chamberlain instalaram o primeiro núcleo presbiteriano paulista.

Antes de 1870, a Academia de Direito exercia hegemonia cultural e intelectual na região. Tanto que São Paulo era conhecida nacionalmente por ser uma espécie de cidade universitária; "burgo dos estudantes" (BRUNO, 1954, p.77) provenientes de diversas partes do país, em busca do valiosíssimo diploma de bacharel em 
Direito (HOLANDA, 1995, p.156-157). Como contraponto à Academia de Direito e ao Seminário dos padres católicos, e no entremeio dessas instituições, a Escola Americana é instalada entre as Ruas São João e Ipiranga:

[...] Todas as minhas reminiscências desses tempos oscillam entre as fazendas do Jaguary e do Pimenta e o scenario dessa obra paciente e colossal que foi a construcção da Estrada de Ferro Mogyana, balouçam entre o Seminario da Luz e a Faculdade de Direito, entre a figura emprehendedora, calma e realmente nobre do conde da Parnaíba e a de meu pae, de cuja incessante actividade, vós paulistas, sois juízes insuspeitos.

[...]

Pelo meu sentimento esta festa tem uma significação muito maior que o commum de celebrações semelhantes. Ella é a primeira formatura ostensiva da vossa Escola, e do exame attento da sua organisação se deve presumir que este facto são as primeiras folhas de uma planta destinada a ser arvore frondosa, propicia a dar fructos sazonados.

Esboçando as suas feições principaes porei em relevo desde já o contraste deste com os demais institutos do paiz.

Primeiramente há a notar o seu regimen de "Academia Livre" fundada pela iniciativa individual e por Ella custeada sem a dependência dos poderes públicos. (LISBOA, 1915, p.57, 59)

Em pouco tempo, na esteira das mudanças que rapidamente vinham ocorrendo em São Paulo a partir da década de 1870, os presbiterianos se inseriram profundamente nesse ambiente, difundindo seus princípios de "aperfeiçoamento ético, intelectual e espiritual dos indivíduos, das famílias e das instituições" (SANTOS, 2010, p.23). Intelectuais, políticos, fazendeiros e pessoas influentes não só passaram a enxergar com bons olhos suas iniciativas, como também passaram a apoiá-los e, no limite, a se converterem à religião protestante. ${ }^{36}$

\footnotetext{
36 Entre as famílias aristocráticas brasileiras que aderiram ao protestantismo presbiteriano e foram membros da Igreja Presbiteriana da capital paulista podem ser citadas:

- D. Gabriela e D. Henriqueta de Couto Esther, irmã e sobrinha do Marquês de Paraná (convertidas por intermédio do Dr. Kalley e recebidas por transferência em São Paulo) Admissão em 4/1878;

- D. Rosa Edite de Souza Ferreira (filha do Dr. Miguel Vieira de Ferreira) e alguns parentes, D. Ana Rita Vieira Ferreira Pinto, e suas filhas, D. Luiza e D. Estefânia - Admissão: 5/1878;

- D. Maria Antonia da Silva Ramos, filha do senador Barão de Antonina - Admissão: 6/1878;

- D. Ernestina Rudge Ramos, neta de D. Maria Antonia da Silva Ramos - Admissão: 9/1882;

- Luís Antônio de Souza Barros, família convertida entre os anos 1870-1890 (LÉONARD, 1963 apud SANTOS, 2010, p.67).
} 


\section{CAPÍTULO II - CONSTITUIÇÃO DA COMUNIDADE MACKENZIE}

\subsection{A missão educacional presbiteriana no projeto civilizatório}

O discurso do protestantismo era desfavorável a qualquer manifestação de preconceito e dava a entender que a educação, enquanto direito do indivíduo, deveria ser garantida indistintamente. Esse foi o caminho que os presbiterianos fundadores do Mackenzie encontraram para se colocarem na sociedade paulista, pois a propositura em garantir o ensino da classe dominante se coadunava com os ideais da classe emergente na formação de uma nova elite para o nascente país republicano ${ }^{37}$. Nesse sentido, a crença de que novas elites dirigentes se formariam pelo processo educacional foi a porta de acesso da missão protestante na sociedade paulista, ainda que esta não tenha dado aderência ao seu projeto originário. Afinal, a ocupação de bancos escolares não franqueava a conversão à nova fé. Em outras palavras, apesar de as elites não se filiarem às igrejas evangélicas, foi nessas classes - sobretudo na maçonaria - que os protestantes do Mackenzie encontraram seus parceiros ideológicos ${ }^{38}$.

Presos às bases estadunidenses, seu "ensino enfatizava o individualismo ético incutindo valores como honra, virtude, respeito mútuo, liberdade, solidariedade e cidadania, o que agradava intelectuais republicanos da época e formadores de opinião que, mesmo sem nunca terem aderido ao protestantismo, viam com bons olhos essas iniciativas, tais como Rui Barbosa, Rangel Pestana, Caetano de Campos, Prudente de Morais e outros" (CALVANI, 2009, p.64).

Apesar de propagandearem a heterogeneidade de sua clientela, a maior parte do público atendido pelo Mackenzie provinha da classe social economicamente dominante. É verdade que, dentro da propaganda inovadora promovida pelos presbiterianos de uma educação democrática e igualitária, havia espaço para segmentos marginalizados da sociedade, como filhos de escravos, mascates e vendedores ambulantes - imigrantes ou não -, mas se tratava de um espaço

\footnotetext{
${ }^{37}$ A cidade de Itu, "tida na época como quartel-general republicano, situava-se em uma região com forte concentração protestante" (CALVANI, 2009, p.66).

${ }^{38}$ Além dos ideais políticos (sistema republicano com estado laico), os protestantes partilhavam com as elites emergentes os ideais filosóficos (positivismo), econômicos (liberalismo) e religiosos (anticlericalismo e anticatolicismo) (CALVANI, 2009, p.66).
} 
restrito, que se fecharia cada vez mais à medida que o tempo passasse e a escola se transformasse num grande centro educacional de excelência.

A partir de 1886, muito embora fossem distribuídas bolsas de estudos e feitas matrículas a preços reduzidos ${ }^{39}$, a grande maioria dos alunos já era constituída por gente abastada que pagava altas cifras, sobretudo para alojarem seus filhos nos internatos do Mackenzie. Essa clientela era constituída, em sua maioria, por brasileiros filhos de imigrantes, filhos da aristocracia cafeeira e, notadamente, pela nova burguesia citadina que despontava com o advento da república. Abaixo, uma relação parcial de alguns "eminentes" alunos e suas respectivas filiações [18891895]:

Quadro 1: Alunos eminentes do Mackenzie durante o período de 1889 a 1895.

\begin{tabular}{lll}
\hline Livro de matrícula $^{40}$ & Aluno & Filiação \\
\hline 1889 & Estanislau de Oliveira & Barão de Araraquara \\
1889 & Ismael dos Santos & Baroneza de Tatuhy \\
1889 & Leonor Salles & Dr. Campos Salles \\
1889 & Vicentina de Moraes & Dr. Domingos de Moraes \\
1890 & Albertina de Campos & Dr. Bernardino de Campos \\
1890 & Antonio Eugenio Dávila & A $^{\text {to Ávila Rebouças }}$ \\
1890 & Gustavo Schaumann & Dr. Henrique Schaumann \\
1895 & Dario Rudge Ramos & E.M. Silva Ramos \\
1895 & João Correa & Barão do Rio Pardo \\
1895 & José de Barros & Viscondessa de Guaratinguetá
\end{tabular}

Fonte: Prado (1999, p.46)

No início do século XX, o já reconhecido Mackenzie College contribuiu significativamente para estabelecer as bases intelectuais da industrialização paulista,

${ }^{39}$ Cerca de $10 \%$ do alunado mackenzista era contemplado por esses benefícios (STEWART, 1932, p.26-27).

40 Outros nomes paternos que figuravam nas listas de alunos são: Manoel E. de Azevedo Marques, Joaquim Candido de Azevedo Marques, C.E. de Azevedo Marques, Dr. Américo de Campos, Cláudio Martins da Cunha, Manoel Joaquim do Amaral, Dr. João B. de Araújo Lopes, João L. do Nascimento Nóbrega, Rodrigues A. Monteiro de Barros, Guilherme Telles Rudge, Dr. Augusto de Almeida Lima, Dr. Antonio Pinto do Rego Freitas, João Maxwell Rudge, Dr. João Augusto Ribeiro da Silva, Dr. João de Toledo Pisa e Almeida, Dr. Laurindo Abelardo de Brito, Dr. Raymundo Pennaforte Blake, Joaquim José do Rego Rangel, Dr. Alfredo Silveira da Morra, Dr. Joaquim José Vieira de Carvalho, Comendador Reis França, Dr. João C. de Moraes, Dr. Augusto Cincinato de Almeida Lima, Dr. Aquilino L. do Amaral, Cap. Antonio B. Quartim, Dr. Eulálio da Costa Carvalho, Dr. Francisco Eugenio Pacheco e Silva, Dr. Miguel Vieira Ferreira, Dr. Francisco de Assis Moura, Martinho Prado Jr., Antonio de Barros Pouyares, Comendador Luiz Antonio de Souza Barros. (RIBEIRO, 1981 apud SANTOS, 2010, p.67). Sophie Miller Capps, que estudou no Mackenzie a partir de 1894, cita outras famílias, entre as quais os Moraes e Moraes Barros. (PRADO, 1999, p.47). 
formando quadros dirigentes que atuaram tanto na política quanto nas administrações empresariais pública e privada, em grande parte, devido a seus cursos de engenharia, comércio, química e arquitetura ${ }^{41}$ (GOMES, 2001, p.176-186).

\subsection{De Escola Americana a Mackenzie College}

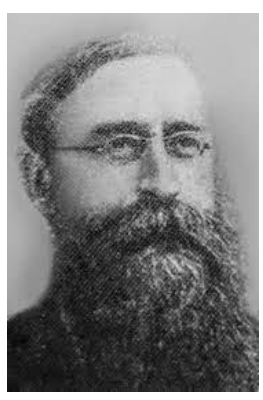

Figura 6: George Chamberlain

São imprecisos os primeiros relatos que versam sobre a origem da Escola Americana de São Paulo. Entretanto, a literatura historiográfica pontua a atuação de um pastor missionário da igreja presbiteriana do norte dos Estados Unidos, George Whitehill Chamberlain, que teria começado suas atividades educacionais entre 1870 e 1871, à rua Visconde de Congonhas do Campo, nos Campos Elíseos, onde Mary Ann Annesley, sua esposa, ministrava aulas para algumas meninas em sua residência ${ }^{42}$ (GARCEZ, 2004, p.47-48). As primeiras menções a essas aulas são identificadas nas atas da Igreja Presbiteriana, mais especificamente, nos Relatórios anuais da Igreja Presbiteriana, escritos por Chamberlain em 1871:

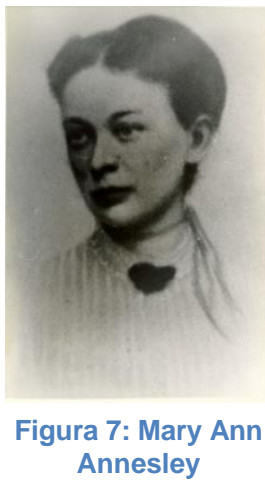

[...] Desde março de 1871 tem funccionado sob a direcção da Snra Mary Dascomb 2 aulas, sendo 1 frequentada por 23 meninos e meninas. (RELATÓRIOS, 1871, p.18)

Nesse mesmo ano, houve a primeira mudança de endereço para a rua Nova de São José - atual Líbero Badaró - com o nome de Colégio Protestante. Aí foi organizada a primeira diretoria da escola, cujos membros eram "Diretor: reverendo Chamberlain; vice-diretor: reverendo Roberto Lenington; diretora interna: Miss Mary Dascomb auxiliada pela professora Palmyra Rodriguez" (GARCEZ, 2004, p.64).

\footnotetext{
${ }^{41}$ Apesar de o comando do Mackenzie estar na mão de um médico (Horace Lane) essa escola não se dedicou à área médica, não obstante o discurso e as práticas higienistas do período. ( $\mathrm{N}$. do $A$.).

42 É curioso notar que o modo como a Escola Americana iniciou seus trabalhos se assemelhava muito a maioria das iniciativas educacionais dos períodos colonial e imperial no Brasil: pequena casa isolada, um único professor para todos os alunos, nenhuma autorização ou regulamentação governamental nem currículos pedagógicos (N. do A.).
} 
De 1872 em diante, a Eschola Americana passou por um intenso processo de ampliação devido ao aumento do número de alunos:

Durante este anno [de 1872] a escola tem tido grande incremento e os exames que tiverão lugar no dia 12 deste mez acreditaram-na muito no conceito publico. Acharam-se matriculados 56 meninos e meninas na escola portuguez. Funcciona em outra sala uma aula de 18 alumnos filhos de pais ingleses. (RELATÓRIOS, 1872, p.273-274)

Em 1875, aconteceu uma nova mudança de endereço para a avenida São João, devido à compra de um terreno por Chamberlain. Nesse momento, a escola passou a se chamar Instituto de São Paulo. É interessante observar que aí se deu a criação de um internato feminino antes do masculino. Curiosamente, em Itu também se construiu, primeiramente, uma escola feminina para, em seguida, os jesuítas fazerem a masculina (Garcez, 2004, p.83-84). Hipoteticamente, sugerimos que, como as meninas seriam donas de lares, era interessante instrui-las nas regras protestantes ou mesmo católicas para disseminarem o credo em suas casas entre seus familiares. O prédio abrigava uma "Sala Grande" usada para o culto religioso da Igreja Presbiteriana e para o Training School (Escola Normal) que se dedicava ao "preparo de pregadores e professores" (LESSA, 1938 apud PRADO, 1999, p.67).

A partir de 1881, com o nome de Escola Americana, deu-se início à edificação de prédios na esquina da Rua Maria Antonia com a Rua Itambé que abrigou o internato masculino e as residências de professores e diretores.

Em 1890, morreu nos Estados Unidos o advogado John Theron Mackenzie, deixando em testamento uma quantia de cinquenta mil dólares para a construção de uma faculdade de engenharia no Brasil. Esse legado seria utilizado anos depois na construção do prédio que abrigaria a Escola de engenharia - inaugurada em 1896 que, em homenagem ao referido advogado estadunidense, recebeu o nome de Mackenzie College. Foi esse também o pontapé inicial para o que futuramente viria a ser o complexo educacional, o instituto e, finalmente, a Universidade Presbiteriana Mackenzie (GARCEZ, 2004, p.137). Nas décadas subsequentes a Classe de commercio se transformaria no bacharelado em Sciencias Commerciaes do Mackenzie College (SANTOS, 2010, p.44-46). 
Desse modo, a Escola Americana, sob o mesmo regime disciplinar e metodológico, passou a contar com cursos que se dedicavam às crianças de mais tenra idade, com o jardim de infância, e aos adultos que ingressavam nos cursos superiores de comércio e de engenharia do Instituto Mackenzie. Assim, formou-se a comunidade Mackenzie, marcada pela padronização dos processos de ensinoaprendizagem graças à confecção de compêndios e à preparação de materiais que seguissem o método intuitivo e objetivo oriundo dos Estados Unidos. Além disso, houve uma homogeneização do quadro docente dos cursos primários e secundários, graças à criação da Escola Normal, de onde saíam levas de professores com formação no emprego do método de ensino adotado pela escola.

\subsection{Percalços na caminhada protestante da Escola Americana}

Aos poucos, a Escola Americana foi ganhando espaço na sociedade paulistana devido, em parte, à sua aceitação por uma parcela da elite citadina. Grandes nomes da alta sociedade que simpatizavam com os ideais progressistas dos presbiterianos e aprovavam seu trabalho educacional colaboraram - tanto com dinheiro quanto com suporte técnico - como é o caso da baronesa de Antonina, Dna. Maria Antonia, que segundo Garcez (2004, p.73-74) vendeu, a preço de custo, o principal terreno onde se instalou o Mackenzie College e fez doações à escola de altas quantias, em espécie, que garantiam os estudos dos filhos de suas escravas. Além dela, outros incentivadores da nova sociedade brasileira contribuíam com doações, como é o caso de alguns superintendentes da Estrada de Ferro São Paulo Railway e de políticos importantes - que viriam a ser presidentes da província e da república - como Bernardino de Campos, Prudente de Morais, Rangel Pestana e Campos Salles.

A utilização da metodologia estadunidense que levava em conta o desenvolvimento da vida prática dos estudantes, junto à adoção de critérios liberais na escolha dos professores - além de presbiterianos, encontravam-se maçônicos, positivistas, abolicionistas, republicanos etc - e a admissão de crianças provenientes das mais diversas crenças (inclusive católicos), sexo e posição política dos pais fez com que, já em seu início, a Escola Americana fosse indicada como referência em educação primária, além de ser elogiada por jornais da cidade: 
Escola Americana - Denominaremos assim a importante escola para meninos e meninas fundada nesta capital, á rua de S. José n. 1, pelo pastor evangelico presbyteriano sr. Chamberlain [...]. A escola assim organisada funcciona apenas ha 5 mezes [...]. Entretanto mostraram todos [os alunos] maravilhoso desenvolvimento, como não estamos nós brazileiros habituados a presenciar nas nossas escolas rotineiras do tempo colonial. [...] Encontra-se ali o ideal americano - escola mixta, regida por mulher. [...] Como os americanos sabem que a palavra é uma arma, e arma indispensável aos cidadãos de um paiz livre, vão desde já sendo applicados a exercicios oratorios os discipulos da escola a que nos referimos (CORREIO PAULISTANO, 1872, p.02. Disponível em: http://memoria.bn.br/DocReader/DocReader.aspx?bib=090 972_03\&pagfis=7882. Acesso em: 12 fev 2021).

Em 1878, acontece a visita de uma grande personalidade à Escola Americana: o imperador Dom Pedro II. Em alguns relatos, o "velho rei filósofo" é descrito como compreensivo, empolgado e satisfeito à medida que vai se inteirando dos procedimentos republicanos e progressistas adotados pela Escola Americana. A visita do monarca fornece alguns indícios do grau de aprovação da Escola Americana na sua primeira década de existência e ainda na época do império (GARCEZ, 2004, p.97-100).

Apesar do grande sucesso da escola, Chamberlain, preocupado com as missões evangélicas, sugere à Junta Missionária de Nova lorque que crie "uma entidade leiga para administrar o Departamento de Educação da Igreja" (SANTOS, 2010, p.47). Daí a instituição do médico estadunidense Horace Manley Lane como o segundo presidente e diretor da escola.

Somente a partir de 1886 - com a administração de Lane - é que surgem registros e documentos oficiais acerca da Escola Americana. Da leitura dos documentos esparsos e de trabalhos como os de Santos (2010) e Garcez (2004), extraímos que de 1870 a 1886 essa instituição passou por diversas modificações principalmente as mudanças de endereço, que ocorreram algumas vezes. Nesse período, a Escola Americana ganhou prédio próprio, abrigando o internato feminino e o externato misto, ainda que tivesse sido necessário "implantar um sistema disciplinar interno com regulamentos e vigilâncias entre estudantes ${ }^{43}$ " (PRADO,

${ }^{43}$ Ao tratar do recreio, Sophie Miller Capps lembra da existência de "um muro [que] separava este recreio do das meninas que ficava na parte interna" (Revista da Associação dos antigos alunos do Mackenzie, 1970 apud PRADO, 1999, p.87) 
1999, p.95). Inauguraram-se o Curso Normal (Training school), o Curso de Filosofia para formação de professores, o "Kindergarten" (educação infantil), o Departamento de Cultura Física para a prática de esportes e ginástica, o Curso Preparatório e a Classe de commercio (LESSA, 1938 apud PRADO, 1999, p.77).

Como já foi mencionado, apesar de todo progresso material e "espiritual" observado nesses anos, os objetivos de Chamberlain em relação à Escola Americana haviam se mostrado muito diferentes do que viriam a ser a partir de Horace Lane, seu sucessor.

\subsubsection{Novos rumos}

Em seus primórdios, a Escola Americana estava associada à necessidade de formação de pastores, evangelistas e à conversão de pessoas comuns ao protestantismo presbiteriano, assim como ocorria nas escolas dominicais anexadas aos templos presbiterianos nos Estados Unidos e nas igrejas presbiterianas imigrantistas no sul do Brasil. O protestantismo precisava obter representatividade política no Brasil e, à época, nada mais prático que investir na educação formal dos cidadãos para cooptá-los. Contudo, devido à grande necessidade de um trabalho educacional sistemático principalmente no âmbito da alfabetização — visto que apenas por este viés seria possível a evangelização - a Escola Americana trilhou um "caminho de mão dupla" no que diz respeito a sua atuação pedagógica: ao mesmo tempo em que era preciso evangelizar e converter novos adesionistas, era necessário educar "laicamente" 44 as pessoas com o intuito de civilizá-las:

O fim do edificio, que se acaba de construir no bairro da Consolação, é receber os moços que se destinam ao ministerio das Igrejas evangelicas e ao magisterio, bem como dar educação leiga aos que quizerem utilizar-se do methodo e disciplina da Eschola Americana. (CHAMBERLAIN, 1885)

\footnotetext{
${ }^{44}$ É preciso lembrar que estamos no período imperial em que se tem a relação estado-igreja católica. Assim como a Igreja Presbiteriana não podia ter templos não podia se constituir como escola confessional. Daí declararem que o ensino era leigo voltado àqueles que quisessem aderir ao método e disciplina da escola. Desvia-se a atenção da religião para a questão disciplinar. (N. do A.)
} 


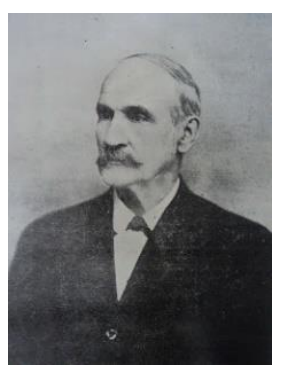

Figura 5: Horace Lane

Com a direção de Lane, a Escola Americana foi profundamente reestruturada e ganhou o estatuto de Mackenzie College. Lane - que se converteu ao presbiterianismo ao receber o convite de Chamberlain para dirigir a Escola - era uma figura controversa no meio presbiteriano paulistano, muito embora fosse considerado um excelente pedagogo e um grande administrador escolar. ${ }^{45}$ Ele não media esforços para realizar seu sonho de construir uma escola de alto-padrão e, por conseguinte, buscava apoio em diversos setores da sociedade, inclusive naqueles mal vistos pela igreja, como é o caso da Maçonaria. Se, de um lado, a proximidade com esses setores contribuiu para a realização do projeto, de outro, gerou polêmicas e discussões sobre a efetiva missão religiosa e educativa do Mackenzie.

Alguns ideólogos logo se opuseram a Lane, como o professor, gramático e pastor da Primeira Igreja Presbiteriana Paulista Eduardo Carlos Pereira, cuja postura mais ortodoxa e nacionalista condenava o modo como o novo diretor encaminhava os trabalhos no Mackenzie. Vale lembrar que Pereira foi professor da Escola Americana antes da chegada de Lane, compartilhando com Chamberlain os princípios evangelizadores da educação presbiteriana. Para o professor Eduardo Carlos Pereira, esta escola deveria atuar na expansão e consolidação das bases evangélicas no Brasil, sobretudo com as crianças, o que implicaria o trabalho de formação de pastores e missionários "pela igreja e para a igreja", excluindo assim aqueles que não tivessem vínculo ou intenção de promover o presbiterianismo no Brasil. Por outro lado, o pastor Pereira acreditava na educação básica pública, onde inclusive lecionou por longo período de tempo, logo após ter saído da Escola Americana. Isso faz com que imaginemos que sua discordância com o Mackenzie esteja relacionada ao financiamento desta instituição pela Igreja Presbiteriana dos Estados Unidos e pela Universidade de Nova lorque, mormente no que toca ao

\footnotetext{
45 Horace Manley Lane nasceu em Readfield, no Estado do Maine, nos Estados Unidos, em 29 de julho de 1837, se mudando logo a seguir para o estado de Massachussets onde teve sua formação inicial. Veio ao Brasil, pela primeira vez, em 1859, dando aulas de inglês em algumas escolas do Rio de Janeiro e São Paulo. Em 1862, no Rio de Janeiro, abandonou o magistério para trabalhar no comércio. Em 1870, encerrou suas atividades como comerciante para viajar à Europa com o intuito de conhecer os modelos educacionais do velho continente. Em 1870, retornou a seu país de origem, onde se formou em medicina, em 1878, pela Universidade de medicina do Missouri. Nos Estados Unidos, exerceu a medicina e trabalhou num jornal como redator-chefe até 1884, quando retornou ao Brasil, sendo convidado por George Chamberlain para assumir a direção da Escola Americana. (SANTOS, 2011).
} 
ensino superior, pois, segundo Pereira, o Mackenzie deveria ser sustentado com recursos brasileiros e não do exterior, como veremos adiante:

[...] houve uma discordância entre o professor Lane e o professor Eduardo Carlos Pereira, referente ao projeto da educação a ser realizada por grandes colégios, pois Eduardo Carlos Pereira era favorável à educação pública ginasial e ao cuidado com a primeira infância por meio das chamadas escolas paroquiais e contrário ao investimento nos grandes colégios confessionais como estratégia de evangelização indireta. Essa discordância gerou uma profunda discussão interna no presbiterianismo brasileiro. (GUTIERRES, 2010, p. 26)

Não obstante as controvérsias criadas pelo professor Eduardo Carlos Pereira, Lane seguiu o programa de sua agenda que previa a aplicação dos métodos pedagógicos e dos princípios éticos e morais provenientes de seu país nas práticas educativas do Mackenzie, com vistas a fortalecer as bases do incipiente capitalismo brasileiro e construir uma república democrática moderna nos moldes da que se verificava nos Estados Unidos. Diferentemente de Eduardo Carlos Pereira, Horace Lane considerava que a religião embasava tais princípios, mas deveria agir apenas indiretamente sobre as coletividades. Para Lane era necessário, antes de qualquer coisa, civilizar o Brasil educando e fortalecendo o mercado interno por meio de um modelo educacional que, segundo ele, e com diversas restrições, era composto "por todos e para todos" (MATOS, 1999, p.16).

Entre essas duas personagens centrais para a compreensão dos primórdios da educação protestante em São Paulo deflagrou-se outro conflito, que opunha o princípio nacionalista à intervenção estrangeira. A Escola Americana e, posteriormente, o Mackenzie College, foi projeto desenvolvido e posto em prática por missionários presbiterianos originários do norte dos Estados Unidos. Esse projeto político era financiado por uma missão nova-iorquina responsável pela implementação do trabalho evangélico e educacional fora dos Estados Unidos. Essa organização missionária já atuava no Rio de Janeiro desde 1859, organizando, além de igrejas, instituições educacionais. Através da Missão Brasileira (Brazilian Mission), como era denominado inicialmente seu órgão de missões estrangeiras no país, a Igreja Presbiteriana do Norte dos Estados Unidos agiu não só no cenário religioso brasileiro, mas, principalmente no educacional, instalando uma rede de 
escolas no país e formando gerações de pessoas propagadoras do seu modelo educacional. Pela extensão territorial, em 1896, a Missão do Brasil dividiu-se em Missão Sul do Brasil, compreendendo os Estados de São Paulo, Rio de Janeiro, Paraná e Santa Catarina ${ }^{46}$ e em Missão Central do Brasil, incluindo Bahia, Sergipe, Goiás, Mato Grosso e Norte de Minas Gerais ${ }^{47}$.

O Mackenzie, desde sua fundação, recebeu ajuda financeira e recursos humanos de uma Junta de Síndicos a que Chamberlain e Horace Lane chamavam The board of trustees, podendo com isso adquirir terrenos, construir prédios e as instalações do colégio:

\begin{abstract}
A organização do Mackenzie College é a seguinte: as propriedades pertencem a uma corporação composta de "trustees" (junta de Syndicos), sendo a responsabilidade delles estabelecida pelas leis que regem a Universidade do Estado de New York. Basta dizer que Ihes é proibido comprar ou vender propriedades do estabelecimento sob o seu cuidado, auferir qualquer lucro ou emolumento dos seus fundos, ficando-lhes em materia de finanças unicamente o direito de fazer doações ao estabelecimento. Esta corporação tem a responsabilidade de manter no Brasil uma organização de conformidade com as normas da Universidade, empregando para esse fim os dinheiros ao seu dispor. Os "trustees" operam por meio do presidente, que é o procurador da junta de syndicos e por meio do conselho no Brasil, que assim não passam a formar uma parte dos fundos pelos quaes a Junta de Syndicos de New York é responsavel. [...] A esta relação para com a Universidade de New York é que devemos as doações que constituem o nucleo de nosso patrimonio e a protecção continuada de amigos estrangeiros. [...]. (STEWART, 1932, p.26)
\end{abstract}

Como mencionado acima, Eduardo Carlos Pereira era um crítico ferrenho do financiamento estrangeiro da obra presbiteriana instalada no Brasil, o que o colocava ainda mais contra Horace Lane - que intermediava o financiamento do Mackenzie pela missão nova-iorquina. A oposição foi tal que, com o passar dos anos, Eduardo Carlos Pereira se afastou do grupo missionário ligado às raízes estadunidenses e fundou a Igreja Presbiteriana Independente - dissidência da primeira igreja presbiteriana — fundada por este último em 1903:

\footnotetext{
46 Em 1906, a Missão da Igreja Presbiteriana do Sul dos Estados Unidos se subdividiu em Missão Leste, com sede em Lavras, Minas Gerais, e Missão Oeste, sediada em Campinas, São Paulo (MATOS, 2004, p. 17).

47 Não obstante afirmar que a Missão Central do Brasil era formada pelos Estados da Bahia e de Sergipe, o Livro de Atas registra que inicialmente, a Missão Central do Brasil, partindo da Bahia, se irradiou para Sergipe, Goiás, Mato Grosso e Norte de Minas Gerais. (Idem, p. 19)
} 
Em 1903 o Rev. Eduardo Carlos Pereira (1855-1923) e seus companheiros fundaram a Igreja Presbiteriana Independente do Brasil. Eduardo Carlos Pereira representava um elemento divisor no presbiterianismo, como criador de um novo ramo. Acredita-se que o cisma ocorreu devido a divergências entre Eduardo Carlos Pereira e os líderes do Mackenzie, especialmente o Dr. Horace Manley Lane. Por questões pessoais, além de divergências relacionadas à educação e ao papel dos missionários americanos, à autonomia do presbiterianismo brasileiro e à questão maçônica. (GUTIERRES, 2010, p.39)

Tomando a religião como princípio formador da ética e da moral e não como fim a ser alcançado, Lane propunha a educação secularizada como objetivo maior da instituição presbiteriana que dirigia, estratégia que lhe serviu para abrir espaços na comunidade paulista de tradição católica:

Não é o objetivo principal nem primário das escolas ensinar religião, i.e., ensinar credos. Considerada em sua relação com os cursos escolares, a instrução religiosa é um meio para o desenvolvimento do caráter e para dar-se fundamento seguro ao treinamento moral; mas em relação com o aluno, é um fim absoluto; deve dar-lhe, de modo que ele as compreenda, as verdades salvadoras do cristianismo. (RIBEIRO, 1987, p.396)

Desse modo, Horace Lane focou o fortalecimento da estrutura do Mackenzie, investindo cada vez mais na empresa educacional, afastando-se, também ele cada vez mais, da Igreja Presbiteriana do Brasil, justamente por razões opostas às de Pereira:

O Mackenzie College secularizou-se progressivamente. O ensino era de excelente qualidade e a escola gozava do mais alto prestígio, mas os propósitos originais dos seus fundadores, no sentido de que a instituição tivesse uma orientação nitidamente cristã e evangélica, eram difíceis de ser mantidos. Nos seus escritos, ao longo dos anos, Horace Lane insistiu no caráter religioso da escola. Em junho de 1898, ele lançou uma publicação denominada The Brazilian Bulletin Organ of Mackenzie College. No primeiro número, Lane diz que o propósito do boletim é chamar atenção para o Brasil e o seu povo e despertar o interesse pelo sistema de educação americana, com fundamento cristão, que está sendo experimentado em São Paulo. Mais além, ele observa que esse sistema leva em consideração o indivíduo integral, treinando a mente, o coração e a consciência para o desenvolvimento do caráter, um caráter cristão, e que as Escrituras Sagradas, como fundamento da educação, fornecem a única base ética sobre a qual se pode organizar a sociedade com segurança. (MATOS, 1999, p.15) 
Através de Horace Lane, a Escola Americana de Chamberlain - criada como extensão de uma Escola paroquial e fundada simultaneamente à instalação da igreja presbiteriana com fins de evangelização - se secularizou nos seus primeiros anos de existência, pois a conjuntura sócio-histórica assim determinava, i.e., a união entre estado e igreja católica pela Constituição Imperial. Com a república consolidada, Lane se sentiu à vontade para declarar finalmente que o ensino não era leigo, pois a Constituição republicana, quebrando o vínculo estado-igreja, eliminou o monopólio católico do ensino e dos templos. Nesse novo cenário sócio-histórico, Lane pôde finalmente declarar as diretrizes protestantes do ensino e propulsionar a cultura protestante, que vem a ser a marca distintiva do Mackenzie College: complexo educacional que toma corpo com ensino em diferentes graus, inclusive no nível superior. Essa marca, porém, passa a ser o seu calcanhar de Aquiles, pois o Mackenzie é acusado de propaganda religiosa, provavelmente, feita por meio da imprensa local por padres católicos que procuravam conter os avanços dos protestantes. ${ }^{48}$ As críticas devem ter se intensificado, pois, como se pode ver abaixo em trecho de um discurso de paraninfo, a própria retórica cientificista dos oradores da época, calcada em sua maior parte nas correntes de pensamento evolucionista e positivista, se esforça em rebater essa afirmação:

Nem podia ser a propaganda religiosa de uma seita a causa deste emprehendimento, pois desde logo se vê que a instrucção por si, não é instrumento efficaz de pregação.

$[\ldots]$

No regulamento interno desta casa eu encontro uma disposição onde há referencia á questão religiosa, e é aquella em que se estabelece que diariamente os alumnos do curso gymnasial superior reúnem-se no salão nobre do edifício Lane para ouvir a leitura das Escripturas e render culto a Deus.

$[\ldots]$

É muito pouco para justificar uma suspeita de propaganda religiosa, e é o mínimo a exigir para que não fosse inteiramente abandonada a moral, mas em todo o caso o sufficiente para demonstrar que aqui não se ensina o atheísmo. (STEIDEL, 1923)

48 Ver texto de Nava (2000), no capítulo 1, em que o autor fala sobre a campanha de hostilização promovida por padres contra o ensino protestante. 
Outra acusação de que o Mackenzie teve que se defender a ferro e fogo foi a de ser um órgão do imperialismo estadunidense, mácula desencadeada pela verba de 50 mil dólares deixada em legado por John Theron Mackenzie para a construção do prédio do curso de engenharia - pontapé para o estabelecimento do complexo educacional - , pela presença de docentes estadunidenses em seus quadros e pelo vínculo cooperativo e colaborativo que fez com a Universidade do Estado de Nova lorque ${ }^{49}$, com equiparação dos diplomas: um prato cheio para as agitações nacionalistas que se manifestavam no período.

No final do século XIX, o sentimento nacionalista verificado em São Paulo extrapolava até mesmo aquele verificado para o Brasil ${ }^{50}$. Os paulistas do entresséculos se viam, eles mesmos, como um grupo coeso que se destacava do restante do país e, por isso, pretendiam a emancipação política. Daí o crescimento de movimentos separatistas que, do ponto de vista historiográfico, ainda não são ao certo considerados monarquistas ou republicanos, escravocratas ou abolicionistas (ADDUCI, 1999, p.119-120). Todavia, no início do século XX, o desejo separatista perde espaço para o anseio de difundir o que a elite ${ }^{51}$ considerava como grandeza e modernidade paulista para outras regiões do Brasil, com o objetivo de estabelecer uma hegemonia política paulista.

O projeto paulista se baseava em princípios modernos que se enrijeciam à medida que novas teorias higienistas e eugenistas provenientes da Europa eram incorporadas. Em linhas gerais, pode-se dizer que a educação - não como forma de promoção do indivíduo, mas sim como promoção da defesa da pátria - e sua higienização constituiam as bases desse projeto, sendo esta última dividida em higienização da urbe (saneamento urbano) e do corpo (miscigenação e consequente branqueamento) (ADDUCI, 2002, p.67). Junte-se a isso a ideia de integridade

\footnotetext{
49 Por sugestão de Ruy Barbosa, o curso de engenharia ficou sob jurisdição da universidade estadunidense. (SANTOS, 2010, p.68)

50 Estudando o item "nação" no vocabulário político desde 1830, Chauí (2000) periodiciza o processo histórico da invenção da nação brasileira: i. "princípio da nacionalidade": o discurso vincula nação e território (1830-1880); ii. "ideia nacional" articula-se à língua, religião e raça (1880-1918); iii. "questão nacional" sublinha a consciência nacional (1918-1960).

51 "A homogeneidade da 'elite política paulista' no período entre 1889 e 1937 [era uma] homogeneidade determinada, em primeiro lugar, pela ausênc ia de qualquer elemento de origem trabalhadora. Em segundo, pela lenta incorporação de imigrantes ou de seus filhos no seio do grupo. Um terceiro ponto seria sua formação educacional, com elevado índice de educação superior, realizada, notadamente, na Faculdade de Direito de São Paulo. O quarto critério é o estreito vínculo familiar entre os elementos do grupo, implicando "uma complexa rede de interligações econômicas e de parentesco" (ADDUCl, 2002, p.05).
} 
territorial e a pretensa unidade da língua portuguesa neste território para se obter uma receita básica do que a elite paulista considerava ser seus princípios nacionalistas.

Nesse período da segunda fase do nacionalismo, em que estavam em jogo as discussões sobre raça, língua e religião (CHAUÍ, 2000), a defesa do Mackenzie vinha pela voz dos paraninfos que, em discurso na solenidade da formatura dos cursos superiores, enfatizavam a necessidade de romper com o regionalismo característico do radicalismo de alguns ideólogos nacionalistas ${ }^{52}$ a fim de incorporar a novidade e, desse modo, despontar à frente dos outros. O orador Arrojado Lisboa assinalava que o progresso se fazia pela ciência e o Mackenzie visava essencialmente a formar uma elite de cientistas. Steidel ${ }^{53}$ lembrava que a ciência não devia ser encapsulada pela noção de nação, pois estando "ainda acima da camada atmospherica da patria e do nacionalismo" não se podia atribuir-Ihe o rótulo de ciência inglesa, americana ou nacional (LISBOA, 1915; STEIDEL, 1923).

Além de se inserir no projeto de formação científica propalado pelo positivismo, o Mackenzie - dentro da proposta de higienização - alardeava o estudo da fisiologia para a saúde do corpo. A partir da prática de exercícios físicos e competições, o Mackenzie formou uma equipe de futebol - Associação Athlética Mackenzie College, em 1898 - e participou dos primeiros campeonatos de futebol paulista. (PRADO, 1999, p.67). Em 1896 introduziu-se o basquete e logo depois outros esportes como voleibol, tênis, handebol, esgrima, atletismo e remo surgiram como opções aos alunos (SANTOS, 2010, p.71).

A participação em competições externas deveria fomentar mais críticas negativas à sua presença na cidade ao mesmo tempo em que rendia propaganda positiva à comunidade mackenzista.

\footnotetext{
52 "Além de conservadores, evolucionistas e elitistas, os nacionalistas liberais paulistas eram indisfarçavelmente racistas e autoritários. Todas essas características, é importante frisar, não foram exclusivas deste grupo. Ao contrário, marcaram, em grande medida, diversos segmentos da intelectualidade brasileira envolvidos no desafio de restaurar o estado e a nação. A diferença principal foi seu acentuado caráter liberal" (ADDUCI, 2002, p.8).

53 "Paulistas em sua grande maioria, os ideólogos nacionalistas tinham ainda frequentemente em comum a passagem pela Faculdade de Direito de São Paulo, onde muitos deles inclusive lecionaram, como é o caso de Vergueiro Steidel" (ADDUCI, 2002, p.4).
} 


\subsection{Centro educacional Mackenzie: a estrutura dos cursos}

A escola protestante trazia na bagagem uma sistemática de ensino que se contrapunha ao método dedutivo e de memorização dos colégios existentes no Brasil imperial, em sua maioria católicos. Os métodos de ensino dos colégios protestantes reproduziam o modelo estadunidense que privilegiava 0 ensino graduado. Em vez da leitura em voz alta e a memorização do conteúdo, o Mackenzie introduziu a leitura silenciosa e o método intuitivo, que seguia o princípio de que o desenvolvimento das faculdades mentais se dá pela observação. Para tanto, a escola investiu em material didático como pedras de ardósia, ábacos, globos, mapas de anatomia, modelos de cabeça, retratos de homens ilustres, microscópios, aparelhos de física e química, aparelhos para ginástica, aparelho telegráfico entre outros utilizados em cursos denominados "Lições de coisas" que tinham como meta implementar um ensino prático e objetivo, no qual cada aluno aprendesse empiricamente e chegasse a suas próprias conclusões:

As aulas são extremamente animadas pela riqueza do material ilustrativo. Pois, cada noção a ser transmitida deve estar apoiada em viva impressão sensorial. Daí os quadros murais de geografia, história, mapas, objetos e figuras de toda ordem para objetivar 0 ensino. A lição de coisas deve permitir à criança contemplar a ocorrência de inúmeros fenômenos naturais reproduzidos por aparelhos usados pelo professor (REIS FILHO, 1995, p. 81).

O Mackenzie também implementou o sistema de ensino misto (ou coeducação) no qual meninos e meninas estudavam juntos. Além disso, não foram adotados castigos físicos como meio de punição a alunos que demonstrassem desvios de conduta (BARBANTI, 1981; AZEVEDO, 1958). No decorrer de suas atividades, o Mackenzie aboliu os "exames apparatosos e espetaculosos do fim do semestre ${ }^{54 "}$ e instituiu os exames mensais "despidos de todo apparato e formalidade":

...não podemos preparar alumnos para os "exames de pontos", nem admittir os exames forçados, e apparatosos, tão queridos dos antigos. Sobre este ponto temos convicções tão profundas, tão certos estamos de que estes espectaculos escholares são altamente prejudiciaes aos alumnos do lado moral e intellectual, que não nos

\footnotetext{
54 Há aí uma crítica velada aos exames realizados nas escolas confessionais de vertente católica que tinham na bancada pessoas ilustres, inclusive o Imperador. (Marilza de Oliveira, comunicação pessoal)
} 
demovem, nem a critica dos adversários nem os rogos de amigos. (ESCHOLA AMERICANA, 1890, p.2)

Em 1877, o Mackenzie fundou o jardim de infância, cujas aulas práticas podiam ser seguidas e ministradas pelas alunas da Escola Normal:

Esta parte do nosso systema, baseado no, hoje bem conhecido, systema Froebel, tem por fim o desenvolvimento intellectual desde a mais tenra idade, por methodos intuitivos e naturaes, tendo sempre em vista as necessidades physicas das crianças, attrahindo-as aos conhecimentos e desenvolvendo as faculdades observadoras, sem fadigas, sem desgostos, sem estudos forçados, sem constrangimento dos corpos e sem lagrimas, mas com alegria e contentamento; aprendendo dos próprios brinquedos e alcançando assim os benéficos effeitos da disciplina, e o uso acertado dos sentidos. (PROGRAMA da Escola Americana 1885-1886 apud PRADO, 1999, p.67)

A grade curricular do Curso Normal contemplava as disciplinas que serviriam de apoio para o ensino dos cursos primário e secundário como métodos de geografia, escrita, gramática, economia escolar, aritmética, história, estudos naturais, desenho, gravuras, música e cultura física. Na constituição do repertório de leitura salta aos olhos a introdução de fábulas gregas, romanas e escandinavas as quais eram usadas como mote para atingir o universo infantil e estimular a aprendizagem por meio da brincadeira. Do ponto de vista da formação do pedagogo, o curso permitia que o normalista tivesse conhecimentos de métodos de ensino e princípios de pedagogia, higiene escolar, psicologia aplicada ao desenvolvimento intelectual das crianças, organização escolar e direção prática das aulas.

A adoção do método intuitivo e de trabalho manual visava a habilitar o aluno a "observar e estudar por si", de modo a desenvolver diferentes espaços mentais:

São já bem conhecidos nossos methodos e processos escholares, no que diz respeito aos princípios pedagógicos, á base ethica e ao objectivo da eschola. Tratamos da educação (E-DUCERE) e não do ensino somente; do desenvolvimento symmetrico de todo ser, physica, intellectual e moral, e não do cultivo de uma ou algumas das faculdades intellectuaes sómente.

Pelo lado PHYSICO. Há seis annos adoptamos o systema do ensino do TRABALHO MANUAL, cuidadosamente graduado em aulas especiaes. Esta parte da eschola moderna, hoje tão generalizada, nos paízes cultos, é de incontestável valor educativo, quando organisada scientificametne com o fim de alargar a base da 
educação, desenvolver o corpo physiologicamente e ao mesmo tempo educar os sentidos e adestrar a mão, cultivar o juízo e dar ensejo ao alumno de apreciar praticamente as qualidades, dimensões e propriedades das cousas que entrão na vida diária, - e não com o fim de ensinar um officio ou substituir a gymnastica.

Pelo lado INTELLECTUAL. Seguimos o systema Americano, tanto nos cursos e na phylosophia pedagogica de Pestallozi, Froebel e Herbart, applicada vantajosamente na America do Norte, como nos intuitos civicos, sociaes e Moraes:

Procuramos despertar e disciplinar toda a intelligencia, habilitando o alumno a PODER SABER, e não a cultivar a memória somente, carregando-a de formulas estéreis e de conhecimentos desconnexos. Calculamos os valores educativos, não pelo que o alumno pode INGERIR, mas pelo que pode DIGERIR e ASSIMILAR. (ESCHOLA AMERICANA, 1895, p.2)

Interessado na construção do imaginário da ordem e do trabalho, o Mackenzie introduziu oficinas de trabalhos em diferentes artes industriais direcionadas aos meninos do internato e do externato, perseguindo a ideia de que a aprendizagem de trabalhos manuais era o caminho para o desenvolvimento intelectual e físico. No firme propósito da construção do imaginário, as Cartas aos pais assinalavam que o trabalho manual e corporal não poderia ter um caráter meramente utilitário, pois "o corpo está tão intimamente relacionado com o espírito que o antigo rifão mens sana in corpore sano encerra verdade importante" (ESCHOLA AMERICANA, 1898, p.1).

O Mackenzie se propunha a ir além da instrução e da técnica, a perseguir a cultura científica que "pressupõe [pressupunha] a posse de um ideal e o habito de avaliar criticamente o valor das coisas por comparação com um padrão theorico". 0 programa da escola de 1904 salientava que a criação das oficinas não visava direcionar os alunos para a aprendizagem de ofícios, mas para o trabalho como um todo (PRADO, 1999, p.104).

No entanto, não se pode excluir o interesse em desenvolver também o ensino técnico-profissionalizante em que o estudante do sexo masculino entraria em contato com trabalhos manuais e administrativos com o objetivo de ingressar no recente mercado de trabalho livre, então instaurado:

[O ensino técnico e profissionalizante tinha como objetivo] preparar profissionais para atuarem no comércio cafeeiro de São Paulo e Santos e atender às necessidades de pessoal especializado nos 
escritórios das fábricas de tecido, cerâmica, metalúrgica e curtumes que se instalavam na capital paulista (SANTOS, 2010, p.49).

Em vez de contrariar a busca pelo desenvolvimento científico, essa leitura, colhida também no depoimento do ex-aluno Alexandre Samuel Malfatti, de que os alunos não saíam bacharéis, mas preparados "modestamente para procurar emprego" (PRADO, 1999, p.87), remete à máxima bíblica de que "Muitos são chamados, mas poucos escolhidos" (BíBLIA SAGRADA, 2000, p.759).

Ressalte-se que o imaginário da ordem e do trabalho também era fomentado pelo movimento positivista que, em São Paulo, nasceu na Escola Normal da Praça e, posteriormente, disseminou-se timidamente entre alguns membros da Escola Politécnica e da Academia de Direito. Tratava-se de um grupo fechado que manifestava uma postura ortodoxa e se desenvolveu, principalmente, no segmento menos abastado da elite intelectual não proveniente de famílias tradicionais. Os positivistas buscavam ascensão política e social através do magistério, daí sua posição um tanto marginalizada dentro da sociedade paulista (ALONSO, 2002, p.120-126). Enquanto corrente ideológica, os positivistas se assemelhavam um pouco aos protestantes, pois eram em sua maioria republicanos, abolicionistas, racionalistas, cientificistas e defensores da inserção dos segmentos populares na vida política e econômica do país. ${ }^{55}$ Defendiam, por exemplo, "a separação da igreja do estado, a implantação do casamento e do registro civis e a secularização dos cemitérios" (BOSI, 2004, p.174). No início do século XX, com a abolição da escravatura e a instauração da república, o positivismo foi perdendo força enquanto movimento organizado, mas por outro lado, devido à implementação em grande escala do ensino técnico e da militarização do estado, seus preceitos racionalistas e cientificistas se ampliaram entre militares, técnicos e engenheiros, como se pode ver no discurso do paraninfo do curso de engenharia em 1916:

A expressão é mais lata, o sentido é mais amplo, e quer dizer, sobretudo no vosso caso, fazer guerra á ignorancia, ou, si preferirdes, menos modestamente, augmentar a vossa cultura,

55 "O positivismo comtiano é o mais difundido no Brasil, principalmente devido à formulação das leis dos três estados. Segundo a formulação comtiana, o espírito humano percorre três etapas sucessivas e ascendentes: a teológica/fictícia - estado em que dominam as forças sobrenaturais; a metafísica/abstrata - estado caracterizado pela crítica vazia e desordem espiritual; e a positiva/real - estado de superação das críticas insuficientes e substituição das explicações religiosas ou metafísicas pelas leis científicas" (MONARCHA, 1999, p.131). 
multiplicar os vossos conhecimentos, enriquecer a vossa erudição scientifica. [...] dia não haverá em que surprezas interessantes, minucias, desconhecidas não se antolhem ao vosso espirito culto, e não sejam por elle apreciadas e estudadas com os elementos que grangeastes neste novo tabernaculo da sciencia, que tanto honra a nossa terra e ennobrece a nossa gente... (KESSELRING, 1916, p.58)

Nas sciencias, muitas das quaes compõe o vosso curso, maximé no domínio da mathematica, que é, no dizer de Augusto Comte, o alicerce de todos os conhecimentos positivos, e, por isso mesmo, a primeira e a mais perfeita das sciencias... ${ }^{56}$ (KESSELRING, 1916, p.60)

O estudo prático e técnico, quando o positivismo e a importância da ciência ganhavam corpo, era o repertório do período (ALONSO, 2002, p.120-126) e o diretor do Mackenzie, Horace Lane, inserido nesse ambiente intelectual, fazia um exercício de futurologia ao vislumbrar uma mescla entre as escolas públicas e as escolas de ensino industrial, seguindo o modelo americano:

E talvez annexas ás escholas publicas havera - á imitação da republica da outra America - escholas de ensino manual-industrial. Um dos resultados immediatos e directos dessa eschola seria fazer respeitar e ennobrecer o trabalho... (ESCHOLA AMERICANA, 1889, p.2)

Seguindo o princípio protestante do enobrecimento do cidadão pelo trabalho (WEBER, 1996), a proposta pedagógica do Mackenzie era, no período, justamente aquela de lidar com "questões práticas" e de "alargar as officinas, logo que for possível, para abrangerem todas as artes industriaes", declaração que deixa entrever clara intenção de se vincular/anexar às escolas públicas, ou seja, de ganhar espaço na organização educacional do estado. Essa interpretação se pauta no fato de que a declaração propositiva do Mackenzie em "alargar as oficinas" faz parte do mesmo texto em que estava a informação sobre as escolas públicas que, por sua vez, se encontrava numa das Cartas aos pais sobre a Escola Americana. A sutileza do apagamento do adjetivo no sintagma preposicionado "dessa escola" cria ambiguidade: o demonstrativo pode remeter ao modelo de escola na "outra América"

\footnotetext{
${ }^{56}$ É interessante observar que o Mackenzie investiu nos cursos de engenharia e de comércio, deixando de lado as áreas de ciências humanas e biológicas, não obstante o diretor, Horace Lane, tivesse formação em medicina (N. do A.).
} 
em que escolas técnicas são vinculadas às escolas públicas, mas, considerando o cotexto, o demonstrativo também pode remeter à Escola Americana. Se o significado imediato do sintagma é a escola pública, o cruzamento de planos referenciais aponta um outro sentido: a Escola Americana. Essa estratégia retórica criava no imaginário da sociedade a equação desejada pelos protestantes ${ }^{57}$ : Escola [Americana] > escola técnica $>$ escola pública $=$ escola. Tal leitura é reforçada sobretudo pelo princípio da ética do trabalho que caracteriza o protestantismo e, dada a conjuntura, se confunde com o laicismo do ensino público do período em questão.

Dentro do espírito da ordem e do trabalho, o programa de 1915 solicitava colaboração dos pais para acompanharem os boletins que traziam informações sobre o progresso do desenvolvimento e os convidava a atentarem para o quadro de aulas dos alunos, de modo a estarem informados das atividades realizadas na escola, e se certificarem da realização das lições de casa. O acompanhamento dos pais visava a "firmar a solidariedade que deve existir entre a família e a escola" (PRADO, 1999, p.75).

Atividades físicas e militares também eram tidas como prioridade no Mackenzie - principalmente entre os homens - partindo da premissa de que a eles fosse garantida a possibilidade de "serem bons pais, maridos, cidadãos respeitáveis preparados para defender sua pátria, fazendo-a crescer e se modernizar" (PRADO, 1999, p.110). Assim, o Mackenzie aparecia também entre os pioneiros no esporte paulista, como foi demonstrado anteriormente. ${ }^{58}$

Para as mulheres, entretanto, havia atividades distintas daquelas realizadas pelos homens, tanto no que toca ao uso do corpo quanto da mente, como sugerem os cronogramas de atividades diárias estabelecidos pelo Mackenzie para ambos os sexos:

\footnotetext{
57 Vale lembrar que em uma das cartas aos pais, Horace Lane afirma ter sido chamado para colaborar com o estado para melhorar o ensino público. (ver adiante)

58 "No internato para o sexo masculino, haverá ginástica, exercícios ao ar livre, passeios e banhos frios, e, se as circunstâncias permitirem, exercícios militares que oferecem um meio excelente de desenvolvimento muscular." (PROGRAMA da Escola Americana, 1914 apud PRADO, 1999, p.68)
} 
Internato para o sexo feminino

\begin{tabular}{c|c|c}
\hline $5 h 45$ & 30 minutos & Chamado para se vestir e fazer orações \\
$6 h 15$ & 15 minutos & Café da manhã \\
$6 h 30$ & 50 minutos & Estudo \\
$7 h 20$ & 25 minutos & Ginástica ou passeio com a diretora \\
$7 h 45$ & 30 minutos & Serviços domésticos \\
$8 h 15$ & 45 minutos & Almoço e culto doméstico \\
$9 h$ & 30 minutos & Serviços domésticos e liberdade e recreio \\
$9 h 30$ & 30 minutos & Aulas \\
$12 h 30$ & 2 horas & Refeição e recreio \\
$13 \mathrm{~h}$ & - & Aulas \\
$15 \mathrm{~h}$ & & Encerramento das atividades diárias \\
& & \\
\end{tabular}

Quadro 3: atividades masculinas

Internato para o sexo masculino

\begin{tabular}{c|c}
\hline $6 h 15$ às $7 h 15$ & exercícios físicos \\
$7 h 15$ às $8 h 15$ & estudo \\
$8 h 15$ às $9 \mathrm{~h}$ & almoço e culto doméstico \\
$9 h 30$ às $12 \mathrm{~h} 30$ & aulas \\
$15 \mathrm{~h} 30$ às $16 \mathrm{~h} 30$ & jantar \\
$16 \mathrm{~h} 30$ às $18 \mathrm{~h}$ & estudo \\
\hline
\end{tabular}

Fonte: Prado (1999, p.110)

Como se vê nos dois cronogramas acima, às mulheres eram reservados parcos 25 minutos de "ginástica ou passeio com a diretora" (o que permanece vago, 
pois não se sabe em que consistem essas duas atividades e qual delas, de fato, era realizada), enquanto que para os homens havia uma hora de "exercícios físicos". Além disso, o item "serviço doméstico" figura exclusivamente no cronograma feminino, o que dá a entender que às mulheres eram ensinados tarefas e afazeres que lhes seriam úteis no interior de seus lares, onde elas se destacariam como boas esposas, mães e donas de casa, o que consistia, possivelmente, no reflexo de uma nova exigência social por parte das famílias da elite paulistana naquele momento.

Ainda que esses afazeres se fizessem presentes nas classes mais populares, - Mackenzie, seguindo o preceito de realizar as "coisas com ordem e exatidão" introduzia como novidade os conhecimentos nutricionais no ensino de arte culinária, tendo realizado inclusive alterações no edifício para as aulas de culinária. Essa iniciativa era condizente com a construção do imaginário da mulher ordeira e trabalhadora presente nas revistas femininas do início do século $X X$, que servisse de modelo para infundir no espírito do filho o sentimento da ordem e do trabalho (PRADO, 1999, p.112):

Se nos temos afastado muito da antiga educação subjectiva, é porque Ella já não satisfaz as exigências justas da civilisação moderna; se não cultivamos, com o enthusiasmo dos outros tempos, a oratória, a rhetorica e o lado ceremonial da vida escholar, é porque achamos estas cousas já bastante desenvolvidas e procuramos equilibrar as forças cultivando os "RES NON VERBA", isto é, o lado objectivo e practico, dando em logar destas artes os conhecimentos do mundo e suas actividades, indispensáveis para habilitar o alumno a enfrentar, do melhor modo, as responsabilidades da vida pratica. $\mathrm{Na}$ coordenação de seus cursos a eschola de hoje é obrigada a considerar não somente a ordem lógica das matérias, o valor relativo dos conhecimentos e da destribuição justa delles; a psychologia do desenvolvimento da criança e seus direitos inolvidáveis, mas também a relação que tudo isto tem com a vida pratica nesta sociedade, tal e qual se acha constituída. Pois o alumno não estuda exclusivametne porque tem de aprender certas matérias, nem exactamente porque tem de cultivar a intelligencia, mas principalmente porque tem de se fazer homem, occupar um lugar e desempenhar um papel qualquer na sociedade; satisfazer as justas exigências industriaes, sociaes e políticas; Moraes e religiosas do meio em que vive. (ESCHOLA AMERICANA, 1895, p.2)

Apesar de todas as inovações já apontadas, grandes mudanças internas da escola que levaram à criação do complexo educacional Mackenzie College estão vinculadas à estrutura dos cursos. Baseados no modelo estadunidense de Grammar School, Training Class, High School e College, no início do século XX, o Mackenzie 
estabeleceu em sua sucursal paulistana cursos seriados/graduados em níveis de dificuldades diferentes. Em princípio, tem-se o curso primário, depois o intermediário, o secundário, o curso normal e os cursos superiores ${ }^{59}$.

Quadro 4: Grade curricular Mackenzie College a partir de 1896

\begin{tabular}{|c|c|c|}
\hline Grau / estágio de aprendi & Tipo de orient & Conteúdos abordados \\
\hline $\begin{array}{l}\text { Primeira seção (3 anos e } \\
\text { português; } 4 \text { anos em ingl }\end{array}$ & $\begin{array}{l}\text { Professor } \\
\text { polivalente }\end{array}$ & $\begin{array}{l}\text { Conhecimentos mecânicos de leitura e rudimentos } \\
\text { processos numéricos adquiridos automaticamen }\end{array}$ \\
\hline $\begin{array}{l}\text { Segunda seção (varia entre } \\
2 \text { anos) }\end{array}$ & $\begin{array}{l}\text { Professor } \\
\text { polivalente }\end{array}$ & $\begin{array}{c}\text { Aprofundamento dos conhecimentos iniciados } \mathrm{n} \\
\text { primeira seção }\end{array}$ \\
\hline Terceira seção (2 anos & $\begin{array}{l}\text { Professor } \\
\text { polivalente }\end{array}$ & História pátria, geografia, aritmética, organização c \\
\hline $\begin{array}{l}\text { Curso inferior de preparatór } \\
\text { anos) }\end{array}$ & $\begin{array}{l}\text { Um professor } \\
\text { cada matér }\end{array}$ & $\begin{array}{c}\text { Ênfase nos estudos preparatórios para os cursc } \\
\text { superiores }\end{array}$ \\
\hline $\begin{array}{l}\text { Curso superior de preparat } \\
\text { (3 anos) }\end{array}$ & $\begin{array}{l}\text { Um professor } \\
\text { cada matér }\end{array}$ & $\begin{array}{l}\text { Estudos de cultura geral com ênfase no programa } \\
\text { carreira escolhida }\end{array}$ \\
\hline $\begin{array}{l}\text { Curso geral ou superior of } \\
\text { especialização ( } 5 \text { anos }\end{array}$ & $\begin{array}{l}\text { Um professor } \\
\text { cada matér }\end{array}$ & $\begin{array}{c}2 \text { anos básicos para todas as carreiras e } 3 \text { de } \\
\text { especialização (no caso das engenharias) }\end{array}$ \\
\hline
\end{tabular}

No curso primário, dedicavam-se à leitura, à caligrafia, à gramática portuguesa e à doutrina cristã, com atenção especial à disciplina, pois

Se na aula primaria não houver disciplina, e se ahi não se dirigir logicamente o processo mental, será mui difficil fazel -o nos estudos secundários, quando os maos costumes já se acham arraigados. (PROGRAMA da Escola americana 1885-86, apud PRADO, 1999, p.115)

A doutrina cristã, a caligrafia e o estudo da gramática continuavam presentes no curso secundário nos dois primeiros anos, introduzindo-se aí a leitura de autores modernos e de clássicos portugueses e as atividades de composição. No último ano, seguia-se a leitura dos clássicos e ganhavam espaço no currículo a literatura nacional, a retórica e a declamação em português (PRADO, 1999, p.80). É curioso o

59 No colégio metodista piracicabano estudavam-se: latim, português, inglês, francês, gramática, caligrafia, aritmética, matemática, álgebra, geometria, astronomia, cosmografia, geografia, história universal, história do Brasil, história sagrada, literatura, botânica, física, química, zoologia, mineralogia, desenho, música, piano, costura, bordado e ginástica. (ELIAS, 2005, p.82). 
fato de que introduziam o ensino de instrumentos de argumentação e oratória que tipificavam o ensino jesuítico, o que sugere que a disputa por fatias do alunado levava à remodelação do conteúdo programático e de metodologias ofertadas pelo oponente, a saber, pelos colégios católicos ${ }^{60}$.

No tocante à organização disciplinar dessa escola, algumas regras de comportamento verificadas em manuais, provavelmente, orientavam tanto a conduta dos alunos quanto a dos pais. Nesse ponto, é possível perceber alguns traços de puritanismo tradicionalmente observáveis nos protestantes:61

\begin{abstract}
"No regimen interno tem-se em vista a mesma boa ordem que deve reinar no seio de uma familia bem organisada, procurando infundir nos animos dos alumnos os principios de honradez, amor á verdade, e obediencia sem que seja preciso fazer muitas regras. As leis inflexivas são sómente as necessarias á moralidade, á conservação da saude e á manutenção de perfeita disciplina. $E$ absolutamente prohibido em todo o estabelecimento o fumo, e o uso de bibidas alcoolicas, sob qualquer pretexto. Exige-se obediencia ás auctoridades constituidas da eschola." (PROSPECTO Mackenzie College, 1893, p.9)
\end{abstract}

No trecho acima, fica bem clara a restrição clássica feita pelos puritanos ao fumo e ao álcool. Noutro ponto, ao prescrever que "Não é permittido passar o domingo fora do internato", a direção do colégio restringe também a circulação dos estudantes pela cidade aos fins de semana, mostrando com isso o grau de confinamento a que o internato - que recebia grandes levas de estudantes do interior - submetia seus alunos. ${ }^{62}$

\footnotetext{
60 Essa competição que levava à renovação, atualização e ampliação dos saberes teve por efeito a melhoria do ensino com reflexo nas escolas públicas do período (RIBEIRO, 2015).

61 "Os valores, ideias e atitudes da Ética Puritana, aproximam-se da ideia familiar de 'vocação'. Deus, acreditavam os puritanos, convocou todo e qualquer homem para servi-Lo, servindo à sociedade e a si próprio em ocupações úteis e produtivas apenas. Antes de ingressar no comércio ou em qualquer outra profissão, o indivíduo deve conferir se ele realmente tem vocação para aquilo, se ele tem talento e pode ser útil à sociedade, se aquele exercício é compatível com o estágio de vida pelo qual ele passa e se ele se sente confiante de que Deus o convocou para tal. Deus não chama ninguém para uma vida de orações e conforto ou a uma existência que não acrescente nada ao bem comum. Seria uma desordem grosseira em qualquer sistema de bem-estar social ser constituído por bandidos, mendigos e vagabundos. [...] por outro lado, 'miséria e danação são os estados daqueles cujo enriquecimento se dá às custas de uma boa vida e do dinheiro público arrecadado pelo governo, gastando seus dias em comer e beber, na prática de esportes e passatempos, sem empregar seu tempo dedicando-se à Igreja e ao bem comum. (MORGAN, 1967, p.37 - Tradução nossa)

62 Embora as proibições e restrições de conduta supracitadas sejam características puritanas, não se pode deixar de lado o fato de que escolas e internatos católicos também estabeleciam
} 
Àqueles que, por uma série de motivos, não conseguissem se conformar aos padrões de comportamento estabelecidos, restava a expulsão, o que, paradoxalmente, aumentava o prestígio e afirmava o ethos do Mackenzie perante a sociedade paulista como instituição de ensino justa e democrática:

"O Director reserva para si o direito de a todo o tempo expulsar qualquer alumno ou alumna dos internatos ou externatos, que recusar obedecer os respectivos regulamentos internos ou por qualquer outro motivo justo." - Não é logar para amansar meninos perversos, nem refugio de meninos expulsos de outras escholas e não se permittem ficar no estabelecimento meninos de maus costumes que, depois de admoestados convenientemente, não se corrigem. (PROSPECTO Mackenzie College, 1901, p.36 - Grifo do autor)

Se os que não se adequavam às regras comportamentais eram convidados a abandonar a escola, outros podiam aspirar voos altos. Com efeito, os cursos superiores do Mackenzie eram comparados aos de algumas universidades do norte dos Estados Unidos, e o aluno que lá tivesse formação básica estava credenciado a ingressar nestas últimas se esse fosse o seu desejo:

O Instituto Mackenzie é uma sucursal da Universidade do Estado de Nova-York e portanto os seus cursos são equivalentes aos das Academias Cornell, Columbia, Union etc. Os estudantes de qualquer curso do "Mackenzie College" serão admittidos à matricula em qualquer Academia dos Estados Unidos no anno correspondente ao que estiverem cursando. (PROGRAMMA do curso superior da Eschola Americana, 1894, p.04)

Do mesmo modo, os professores do Mackenzie eram provenientes de diversos países da Europa, dos Estados Unidos e do Brasil, o que Ihes atribuía um caráter cosmopolita e produzia o efeito de sentido de diversidade de ideias que ali circulavam. O material didático era, em sua maior parte, produzido pelos próprios professores ou traduzido por eles. Além de estrangeiros das mais diversas nacionalidades, também havia personalidades intelectuais e políticos brasileiros que integraram seu quadro docente:

Realmente a Escola Americana reunia uma plêiade de mestres com grande preparo cultural: Júlio Ribeiro (autor da afamada gramática da

limitações parecidas a seus alunados - como evitar o contato entre internos de institutos diferentes (Marilza de Oliveira, comunicação pessoal). 
Língua Portuguesa), Eduardo Carlos Pereira (autor da Gramática Expositiva da Língua Portuguesa), Antonio Bandeira Trajano (que acabava de publicar sua famosa Aritmética), Santos Saraiva (organizador do Dicionário de Língua Latina), Carvalho Braga, Zacarias de Miranda. Alguns, estranhos ao credo protestante: o grande jornalista republicano e abolicionista dr. Francisco Rangel Pestana que fundara o jornal $A$ província de São Paulo (hoje $O$ Estado de S. Paulo), drs. Aquelino do Amaral, Antônio Veloso, Melquiades Trigueiro e o celebrado poeta Theóphilo Dias. Nas classes primárias, as missionárias: Miss Dascomb e Miss Kuhl, e as distintas professoras Adelaide Molina (vice-diretora interna), Alexandrina Braga e Mary Chamberlain, esta a fundadora da Escola e introdutora do método intuitivo do ensino silencioso (GARCEZ, 2004, p.97-98).

O investimento no preparo dos professores era salientado na Carta aos Paes em que o diretor expressava o desejo de extensão ao Brasil de congressos de educação, como as "Escholas de Verão" americanas "onde se reunem annualmente milhares de educadores, passam-se os methodos e processos de ensino em severa revista critica, eliminando-se o ruim e apurando-se o que tem de bom qualquer que seja a sua procedencia." (ESCHOLA AMERICANA, 1897, p.2).

O Mackenzie alcançou estar entre os principais colégios do país como o Colégio Pedro II e o Colégio Abílio, ambos na Capital de então, Rio de Janeiro. Ganharia ainda um certo destaque quando, em 1890, o então presidente da província de São Paulo, Prudente de Morais e o diretor da Escola Normal, Caetano de Campos, convidaram Horace Lane, a professora miss Márcia P. Browne e a professora Maria Guilhermina Loureiro de Andrade - todos do Mackenzie College para colaborarem na implantação de uma escola pública modelo em São Paulo, com a intenção de formar quadros que pudessem atuar nos ensinos primário e normal do estado (SANTOS, 2010, p.50-51). De acordo com as palavras do próprio Horace Lane:

[...] A escola [Americana] de São Paulo tem tido o privilégio de fornecer planos e métodos para a organização de duas Escolas Normais do Governo, bem como professores para o treinamento em uma delas. Há constante atendimento em nossas escolas primárias de professores jovens e professores de escolas normais, ansiosos por aprender o trabalho prático de nossos métodos. Durante o ano passado, muitos professores da Escola Normal do Governo de São Paulo foram alunos em nossas classes de botânica, música vocal e desenho (LANE apud HACK, 2003, p. 86). 
O ensino público paulista e os cursos para formação de professores para atuarem nos popularmente conhecidos grupos escolares se apropriaram de alguns aspectos do modelo estadunidense do Mackenzie, entre outras coisas, porque grandes líderes intelectuais e mentores da reforma educacional advinda da proclamação da república - como o entusiasta republicano Rangel Pestana acreditavam que o modelo de ensino mais adequado para a construção de uma república bem sucedida era o modelo protestante do Mackenzie.

\subsection{A recepção do Mackenzie pela sociedade paulistana}

\subsubsection{A perspectiva mackenzista}

À época do início da república, havia em São Paulo poucas escolas que davam conta do ensino básico e elementar. Até o ano de 1900, eram aproximadamente 30 estabelecimentos públicos em todo o estado, sendo 11 na capital, número exíguo para uma população de aproximadamente 240 mil habitantes. ${ }^{63}$ Além dos escassos colégios e grupos escolares públicos, pessoas abastadas do estado de São Paulo e de outros estados, podiam contar com alguns colégios particulares (todos católicos) como o Colégio São Luís, Colégio Diocesano, Colégio Nossa Senhora de Sion e Liceu Coração de Jesus. A escassez de vagas escolares era muito grande, o que as tornava concorridas e atribuía prestígio às instituições que as fomentavam.

A prática da reserva de vagas era comum na Escola Americana desde seus primórdios, motivada pela falta de equilíbrio entre oferta e procura pelas escassas matrículas oferecidas:

Os logares dos alumnos já matriculados serão reservados sómente até o dia 03 de fevereiro: desta data em diante, não havendo pedido em contrário, serão dados a outros. (ESCHOLA AMERICANA, 1890, p.1)

Os logares dos actuaes alumnos serão reservados até o dia 06 de Fevereiro sómente. Se por qualquer motivo os Paes não poderem mandal-os antes desta data, terão a bondade de avisar o director, por escripto, pedindo que lhes sejam reservados os lugares,

${ }^{63}$ Disponível em: < http://www.crmariocovas.sp.gov.br> Acesso em 19 set 2018. 
correndo, neste caso, as despezas por sua conta, como se os alumnos estivessem presentes. (ESCHOLA AMERICANA, 1898, p.1)

Ao longo dos anos, houve um aumento considerável do número de alunos no Mackenzie. Já em 1890, é salientado que muitas matrículas foram recusadas devido à falta de espaço físico para comportar um número crescente de alunos:

[...] Os edificios não comportam maior numero sem prejuízo das condições hygienicas, e não nos tem sido possivel augmenta-los como esperavamos. Por esse motivo temo nos visto obrigados, como nos annos anteriores, a recusar muitos alumnos, tanto para o externato como para os internatos. [...] (ESCHOLA AMERICANA, 1890, p.1)

[...] A Eschola foi fundada em 1870, começando a funccionar regularmente em 1871. Conta, pois, 29 annos de existência. Ao passar para o novo século, seja-nos permittido completar aqui a pequena estatística da actual administração, dada em 1895. Durante este período, de 14 annos apenas, temos recebido não menos de 6077 alumnos, dos quaes tiveram educação gratuita, 1571 externos e 223 internos. [...] (ESCHOLA AMERICANA, 1899, p.1)

Do total de alunos nos primeiros 14 anos de atuação, aproximadamente 10\% tiveram educação gratuita no Mackenzie em regime de bolsa de estudo. Considerando o complexo Mackenzie, o perfil do alunado era bem diversificado. Além da variação etária - de 3 a 25 anos (1889) e de 6 a 25 anos (1899) a diversidade é marcada pela língua e pela religião. A tabela a seguir apresenta a evolução quantitativa do alunado mackenzista:

Quadro 5: Matrículas de alunos no Mackenzie de 1889 a 1899

\begin{tabular}{c|c|c}
\hline \multicolumn{2}{c}{ Data } & \multicolumn{2}{c}{ Idade } & $\mathbf{N}^{\circ}$. de alunos \\
\hline 1889 & 3 a 25 anos & 393 \\
1890 & 3 a 25 anos & 447 \\
1891 & - & - \\
1892 & 3 a 25 anos \\
1893 & 4 a 20 anos \\
1894 & 5 a 22 anos \\
1895 & 5 a 25 anos & 513 \\
\end{tabular}




\begin{tabular}{c|c|c}
1896 & 5 a 25 anos & 501 \\
1897 & 5 a 25 anos \\
1898 & 5 a 25 anos \\
1899 & 6 a 25 anos & 522 \\
\multicolumn{2}{|c}{ Fonte: Eschola americana (1889-1899) }
\end{tabular}

Entre as críticas feitas contra o velho regime imperial, estava aquela concernente ao excesso de feriados. A assiduidade na frequência das aulas não era um ponto forte, principalmente nos dois primeiros anos da República, devido aos frequentes festejos:

Notar-se-há que o termo médio de frequencia é relativamente pequeno; procuramos combater, no que é licito nossa interferencia, este mal, que attribuimos ao facto de observarem com rigor descomunal todos os dias de festa do antigo, bem como todos os do novo regimen. O mal parece irremediável e não deixa de prejudicar a marcha do trabalho. (ESCHOLA AMERICANA, 1892, p.2)

Embora enfeixasse a crítica do excesso de festejos ${ }^{64}$ de súditos e de cidadãos dentro do "desenvolvimento do espírito de patriotismo e civismo", o diretor não deixava de registrar que o calendário de feriados era imutável e que isso prejudicava o andamento dos cursos no Mackenzie.

Além de apontar os números que mostram a aceitação do Mackenzie, o diretor Horace Lane fazia questão de assinalar o seu envolvimento com a construção do ensino público do estado de São Paulo:

...e se tambem pedimos para nós um pequeno quinhão de gloria pela
revolução que se tem operado na instrucção publica de S. Paulo, de
certo não nos será levado isto em conta de reclame, que nunca
fazemos, mas a uma pequena e natural expansão que sentimos ao
celebrar o vigésimo quinto anniversario da eschola. (ESCHOLA
AMERICANA, 1895, p.2)

${ }^{64}$ As comemorações das festas do antigo e do novo regime repercutiam a instabilidade política do período. A participação popular que tinha sido "cosmética" na proclamação da República ganhava uma nova dimensão que ia desde passeatas e greves a atentados contra Prudente de Morais (CARVALHO, 1997, p.70). 
O seu "quinhão de gloria" é salientado quando registra a influência dos métodos do Mackenzie não somente nas escolas públicas como nas demais escolas particulares:

O grande desenvolvimento da instrucção publica em S. Paulo tem influído beneficamente sobre as escholas particulares, obrigando-as a melhorar os processos e o material; a adaptal-os á educação moderna, e a respeitar os verdadeiros interesses do alumno e da sociedade. A Eschola "Modelo" não sómente tem despertado novo interesse, e creado mais dicidida tendência á moderna educação, mas, ao mesmo tempo, tem estabelecido pontos de comparação, por onde os Paes podem avaliar melhor os resultados. (ESCHOLA AMERICANA, 1896, p.2)

Assim, o diretor faz questão de mostrar que, em efeito cascata, o Mackenzie vinha se colocando como modelo para as escolas públicas e particulares de todo o Estado.

\subsubsection{A recepção da perspectiva externa ao Mackenzie}

A literatura memorialista bem como a historiográfica da cidade paulistana no entresséculos pontuam o surgimento de escolas estrangeiras e nacionais, entre as quais situa-se o Mackenzie:

Surgiram várias escolas criadas por elementos de colônias estrangeiras radicadas na cidade, desenhando-se particularmente 0 ensino alemão e depois o americano, com métodos novos e abolição dos castigos corporais. Nos últimos anos do século passado estabeleceram-se a Escola Politécnica e a Escola de Engenharia do Mackenzie College, e a Escola Normal foi transferida para um edifício de grandes proporções. No começo do século atual fundaram-se as primeiras escolas de comércio e a Faculdade de Medicina. (BRUNO, 1954, p.1254)

O autor fornece dados históricos e destaca o anúncio promovido por Lane apontando que a escola visava o estudo obrigatório da fisiologia para fins de saúde, "desenvolvimento físico e formação de costumes puros" e que o ensino era regido pelo método "intuitivo e objetivo", declinando o estudo "em voz alta, a decoração excessiva com pouco estímulo para o pensamento. 
Jorge Americano também recupera o Mackenzie no momento da implantação dos cursos superiores e da ampliação de seu locus social estabelecido no bairro de Higienópolis:

\begin{abstract}
A Escola Americana, fazendo parte do grupo Mackenzie, quando a conheci, era na Rua S. João, lado ímpar, numa esquina, construção em tijolo aparente. Quando se instalaram o Mackenzie College e a Escola de Engenharia Mackenzie, no terreno limitado pelas Ruas Maria Antônia, Itambé, Piauí e chácara Lane que dava para a Rua da Consolação, mudou-se, com eles a Escola Americana. (AMERICANO, 1957, p.447)
\end{abstract}

O Mackenzie é lembrado por ter auxiliado o governo republicano por ocasião da criação das Escolas-Modelo para as quais foram escolhidas pedagogas que pudessem assumir a sua direção:

Graças, porém, à intervenção do Dr. Lane, diretor da Escola Americana, o problema foi resolvido a contento. O Dr. Lane indicou as duas pessoas que deveriam dirigi-las. Eram duas senhoras portadoras de valiosas credenciais: D. Maria Guilhermina Loureiro de Andrade e Miss Márcia P. Browne. (MOTTA, 1947, p.87)

Como já relatado mais acima, Miss Browne, pedagoga do Mackenzie, auxiliava Caetano de Campos na reforma da Instrução. Essa proximidade entre o Mackenzie e as Escolas-Modelo da Escola Normal do Estado contribuiu para a organização do ensino primário da cidade de São Paulo, intervindo indiretamente na organização das escolas particulares que implementaram reformas no conteúdo programático, metodologia e organização disciplinar que se assemelhavam ao modelo educacional mackenzista.

\title{
2.6. O Mackenzie e a construção do ethos da nova elite paulistana
}

As inspirações republicana e democrática, aliadas ao discurso modernizador advindo dos Estados Unidos contribuíram para criar um status quo privilegiado para aqueles que frequentavam e mantinham algum contato com o Mackenzie. Por isso, o propósito religioso original e o caráter filantrópico dessa instituição que oferecia bolsas de estudos no início de suas atividades, num determinado momento, foram relegados a um segundo plano, mais especificamente a partir da administração de 
Horace Lane, como mencionado anteriormente, quando o Mackenzie se transformou gradativamente numa instituição de ensino de ponta, o que exigiu cada vez mais o reconhecimento e formas de recompensa a seus alunos, resultando no reconhecimento e na consagração social do próprio Mackenzie enquanto instituição de ensino:

Nos podemos offerecer aos nossos alumnos privilégios especiaes ou regalias senão os que resultam da convicção intima de terem feito honestamente seu curso, e, com exames sérios, conquistado seu titulo, seja o de Madureza ou o diploma de Bacharel. Estes documentos, dados sob a responsabilidade d'um corpo tão respeitavel e antigo, como é o dos "Regents of the University of the State of New York", embora não tragão proventos ou isensões, não deixam de ser titulos de honra de alto valor moral, mas não dão nem tiram as qualidades pessoaes ou as aptidões com que se conquistam as altas posições sociaes (PROSPECTO Mackenzie College, 1900, p.31)

Nessa segunda fase do Mackenzie, sob a direção de Lane, era plausível que os aptos a ingressarem, se manterem e a se formarem no Mackenzie constituíssem uma módica parcela da elite paulistana, a saber, aqueles que adquiriram ainda na primeira infância e de maneira inconsciente, boa parte dos princípios morais e da cultura erudita exigida pela instituição escola em seus moldes iluministas (BOURDIEU, 2007b, p.258). A estes estaria reservado o sucesso social e postos estratégicos de trabalho e direção da elite. A perspectiva do racionalismo industrial adotada de um modo provinciano da Europa e dos Estados Unidos por políticos e intelectuais da Belle Époque paulistana e o quadro social que se delineava no entresséculos, como pitorescamente é apresentado abaixo, fornecem indícios dessa polarização, resultante, entre outras coisas, de uma profunda desigualdade social observada naquele contexto histórico:

O aprimoramento da vida urbana no sentido europeu em detrimento das raízes culturais locais, seduzem amplos seguimentos de uma burguesia recém-endinheirada, à procura de refinamento e formação de gosto pessoal e empenhada na aquisição de traços distintivos. [...] Vista de longe, a silhueta urbana adquire o brilho de cartão -postal. [...] Sonho de pesadelo, a imagem de cartão-postal mistura-se com outras imagens desagregadoras: colunas de fumaça negra produzidas pela combustão do carvão coque, multidões errantes de despossuídos, ascensão das greves e explosões espontâneas. A pobreza urbana e as massas despossuídas ganham uma visibilidade ameaçadora, originando um estado de alerta e inquietação entre os observadores sociais (MONARCHA, 1999, p.225-226). 
Os "títulos de honra de alto valor moral" a que se referem os prospectos do Mackenzie e que garantiriam aos mackenzistas laureados "altas posições sociais" denunciam a intenção escolar de conservar os privilégios da elite, o que de certa forma já era feito pelo sistema escolar imperial brasileiro, apesar de sua precariedade.

Desse modo, embora mantivesse um discurso pautado em ideais de justiça e igualdade, em que princípios liberais privilegiariam todos aqueles que tivessem livre iniciativa e competência para alcançar bons resultados "sem distinções"; apesar do discurso de que a educação, enquanto direito do indivíduo, deveria ser garantida indistintamente, é clara a intenção de criar uma elite "de fato e de direito" que obtivesse todas as distinções possíveis a partir das credenciais educacionais fornecidas pela instituição Mackenzie, elite esta capacitada para dirigir o desenvolvimento de São Paulo:

O nosso método essencialmente democrático presta-se à formação de uma elite de facto e de jure. [...] No sistema verdadeiramente democrático, que procuramos praticar, o aluno que 'naturalmente pode', vai adiante. Quem não pode, cai. [...] Para aqueles que têm capacidade e vontade o curso está aberto desde o princípio até o fim e é nas diferenças naturais de capacidade intelectual e ainda mais nas de caráter, que se desenvolve uma diferença entre um estudante que alcançou simplesmente e o que alcançou distinção. Essa diferença faz uma base sólida e justa para uma elite verdadeira. [...] Esta elite de esforço e de caráter é a honra de todos os países civilizados e abrir seu rol a todos os pretendentes de qualquer classe social é dever da nação. (STEWART, 1932, p.23 - Grifos do autor)

Percebemos, nesse tipo de comentário, uma alusão às teorias evolutivas de Darwin e Spencer. Quando é dito que "... o aluno que 'naturalmente pode', vai adiante. Quem não pode, cai...", a referência a uma possível seleção natural na qual só os mais fortes sobrevivem mostra-se evidente. Além disso, a concepção meritocrática se explicita quando é dito que "... Para aqueles que têm capacidade e vontade o curso está aberto desde o princípio até o fim...", deixando subentendido que democracia - do ponto de vista do Mackenzie - não seria um sistema político "essencialmente" agregador e inclusivo (como se verificava em seus discursos), mas sim um modelo voltado essencialmente para aqueles que já integravam a elite, estendendo-Ihes ad infinitum os privilégios em convergência com a máxima bíblica, 
já citada anteriormente, "Muitos serão chamados, mas poucos escolhidos" (BÍBLIA SAGRADA, 2000, p.759).

Em relação à igualdade de acesso - sempre enfatizada nos textos e discursos do Mackenzie - verificamos a tentativa de se manter uma postura neutra diante da questão do mérito a ser alcançado pelo alunado. Busca-se um efeito de imparcialidade que dá a entender ao leitor que todos os indivíduos poderiam atingir o grau máximo de exigência solicitado pelo Mackenzie caso quisessem realizar esse feito. Entretanto, o que de fato ocorria era o estabelecimento de uma nova cultura escolar com a qual o público brasileiro (mesmo aqueles provenientes dos estratos mais abastados) não estava acostumado. Parte de uma elite propensa a conhecer ou, no limite, já minimamente conhecedora de traços da cultura protestante estadunidense poderia usufruir com algum êxito dos serviços oferecidos pelo Mackenzie. Daí que, oferecer de modo igualitário algo que não era conhecido em pé de igualdade por todos, acabava por reforçar a ideia de desigualdade. Nesse campo de atuação, os estudos do sociólogo francês Pierre Bourdieu trazem à tona alguns esclarecimentos:

\begin{abstract}
A igualdade formal que pauta a prática pedagógica serve como máscara e justificação para a indiferença no que diz respeito às desigualdades reais diante do ensino e da cultura transmitida, ou melhor dizendo, exigida. [...] a tradição pedagógica só se dirige, por trás das ideias inquestionáveis de igualdade e universalidade, aos educandos que estão no caso particular de deter uma herança cultural, de acordo com as exigências culturais da escola. Não somente ele exclui as interrogações sobre os meios mais eficazes de transmitir a todos os conhecimentos e as habilidades que a escola exige de todos e que as diferentes classes sociais só transmitem de forma desigual, mas ela tende a desvalorizar como "primárias" (com o duplo sentido de primitivas e vulgares) e, paradoxalmente, como "escolares", as ações pedagógicas voltadas para tais fins. (BOURDIEU, 2007b, p.53)
\end{abstract}

Partindo da premissa acima, podemos afirmar que alguns fatores sociais seriam determinantes para a excelência escolar. Dentre eles, destaca-se a lei geral que rege os processos de seleção e eliminação. Assim, aqueles que se distinguem, se distinguem devido a um conjunto sistemático de vantagens sociais que os coloca na dianteira em relação a seus concorrentes, e pertencem, se comparados à maioria 
das pessoas, "a ambientes mais favorecidos tanto do ponto de vista do prestígio social como do ângulo do capital cultural":

Como vemos, não há distinção propriamente escolar que não possa ser relacionada a um conjunto de diferenças sociais sistematicamente associadas. Na verdade, a hierarquia no interior da elite escolar - ela mesma separada por diferenças sociais da população no interior da qual ela é recrutada mediante uma extração socialmente comprometida - pode ser associada a diferenças sociais. (BOURDIEU, 2007a, p.238)

O alcance da distinção por parte do alunado era a grande meta do Mackenzie College que, nesse sentido, colocava em prática os preceitos de uma cultura protestante, liberal e aristocrática, incipiente no Brasil, a serviço da formação de uma nova elite de laureados. Historicamente, essa elite cujo habitus escolar fora estruturado no Mackenzie College - constituída majoritariamente por contadores, administradores de empresa e engenheiros - seria, então, responsável por dirigir os rumos dos desenvolvimentos econômico e social de São Paulo ao longo do século $\mathrm{XX}$. 


\section{CAPÍTULO III - A tessitura do texto e a referenciação: a construção do ethos da comunidade Mackenzie}

\subsection{Apresentação do corpus}

Para acessarmos a elaboração do imaginário e construção do ethos da comunidade Mackenzie, realizamos o estudo da tessitura do texto e de processos de referenciação. Para tanto, compusemos uma amostra formada por dois tipos de documentos produzidos no ambiente administrativo:

i. Cartas do diretor Horace Lane aos pais de alunos, por meio das quais dá as diretrizes da escola, focando no ensino inovador baseado em metodologia estadunidense;

ii. Prospectos em que são fornecidas orientações sobre o funcionamento da escola.

Compusemos uma segunda amostra constituída por dois documentos de maior formalidade:

iii. Discursos de paraninfos e discursos de formandos.

Uma terceira amostra é constituída por textos extraídos de três revistas acadêmicas, a saber:

iv. Revista de Engenharia, Revista Avatar e Revista Progresso.

\subsubsection{Cartas aos Paes}

Trata-se de dez cartas de administração privada, datadas de 1889 a 1899 e escritas pelo diretor da escola à época, Horace Manley Lane, dirigidas aos pais dos alunos da Escola Americana. Nessas cartas, por meio de uma escrita enxuta e pragmática, Lane expõe questões relacionadas a matrículas de alunos, resultados de desempenho e apresenta diversas avaliações do que era a escola naquele momento, além de relatar suas ambições para o futuro. Chama a atenção, nessas cartas, as comparações feitas por seu autor entre o modelo educacional europeu e o americano, sendo este último, segundo ele, o caminho ideal a ser trilhado pelos 
brasileiros para alcançarem um alto grau civilizacional por meio de princípios republicanos e democráticos estadunidenses:

Na Europa achamos na organisação do ensino popular, muito pouco que possa, com proveito, ser transplantado para o Brasil, quer nos methodos quer no objectivo. Nos paizes onde existe a melhor organização escholar, o resultado corresponde exactamente aos desejos dos respectivos governos - fazer cidadãos adaptáveis ao complicado mechanismo dos systemas antigos, creando um espírito de sujeição e subordinação tão severo que chega a ser quase servil. N'outros paizes, onde a organisação parece theoricamente boa, 0 producto não é o que ideamos para um paiz livre. (ESCHOLA AMERICANA, 1894, p.2)

Essas cartas serviam como propaganda da escola para a elite paulistana. Por meio delas, as famílias recebiam informações sobre um centro educacional "inovador", cuja proposta pedagógica "era o que havia de mais moderno e sofisticado no mundo" no tocante ao modelo de ensino e ao desempenho dos alunos, tomando-os como parte importante do processo de organização do plano de ensino:

É longo e penoso o trabalho de aproveitar todos os detalhes, conglobando-os em um todo acessível á intelligencia de todos os alumnos e coordenal-os com os sãos princípios da pedagogia; tomar, como é necessário, o alumno como factor indispensável do plano; estudar as suas necessidades e possibilidades physiologicas, a ordem natural do seu desenvolvimento intellectual; construir em torno delle os cursos, e preparar, deste modo, o material para elle. (ESCHOLA AMERICANA, 1889, p.2)

Essa proposta de ensino considera as peculiaridades dos alunos, de forma a graduar o conhecimento e dá-lo a conhecer por via intuitiva:

O desenvolvimento e a applicação de novos methodos ao ensino primário, a confecção de compêndios pelos mesmos methodos, e o preparo de novos materiaes para o ensino objectivo intuitivo, têm progredido a passos vagarosos, mas seguros. É este o trabalho mais importante, e ao mesmo tempo mais difficil da Eschola. (ESCHOLA AMERICANA, 1889, p.2)

O método intuitivo se faz pela dedicação ao trabalho sistemático e metódico, visando a desenvolver e explorar holisticamente os sentidos e os "atributos físicos e intelectuais": 
Este nosso ensaio, apezar de imperfecto, tem mais do que correspondido á expectativa, mostrando claramente o grande valor educativo do trabalho manual systematicamente ensinado, e a practicabilidade de consagrar um certo numero de horas ao trabalho methodico, sem prejuízo, antes em beneficio, dos estudos formaes. O fim deste trabalho não é tanto fazer officiaes dos diversos officios, ampliar as bases da educação, desenvolver o uso accurado dos sentidos e dar maior desenvolvimento aos atributos physicos e intellectuaes, simultânea, symetrica e harmoniosamente. (ESCHOLA AMERICANA, 1889, p.2)

Escrita dias após o evento da Proclamação da República, a carta datada em 6 de dezembro de 1889 já traz uma crítica ao passado recente e às práticas de usufruto de privilégios que o novo regime se propõe a desfazer:

Um dos resultados immediatos e directos dessa eschola seria fazer respeitar e ennobrecer o trabalho, aviltar e tornar deshonrosa a vadiação, augmentar o numero dos productores e diminuir o dos consumidores, elevar o nível da vida social, e destruir os preconceitos nascidos dos systemas tacanhos do passado. (ESCHOLA AMERICANA, 1889, p.2)

Dez anos após a Proclamação da República, quase a comemorá-la - carta de 17 de novembro de 1899 - dá-se continuidade ao alerta sobre a necessidade de homens preparados para a construção do país, com a ressalva de que as virtudes cívicas devem se sobrepor à ciência. Já salientamos mais acima que inicialmente a escola se dizia laica, mas que, uma vez consolidado o novo regime de governo, se declarou confessional:

A Republica precisa de homens aptos, capazes de prestarem a attenção séria ás cousas sérias e de pôr em pratica as virtudes cívicas. Conhecimentos sem caracter constituem um verdadeiro perigo. Os tempos exigem que a sciencia seja subordinada á pratica do bem. (ESCHOLA AMERICANA, 1899, p.2)

As cartas do diretor revelam algumas informações estatísticas como o número de alunos matriculados naqueles respectivos anos e a origem pátria dos mesmos, assim como a quantidade de bolsas de estudo oferecidas e também o perfil de alguns cursos como o Kindergarten, a oficina de trabalhos manuais, o curso normal e alguns cursos superiores (ver itens 2.4, 2.5.1, 3.2.1 e seguintes). 
A origem vária do alunado, em termos étnicos, sociais e de gênero, espelhava a conjuntura social paulista do período, marcada por fortes correntes imigratórias. Por conseguinte, fornecia o desafio de construir o sentimento de uma comunidade, de uma identidade coletiva, por meio de um programa de homogeneização educacional. Apesar desses propósitos homogeneizantes, a proposta reverberava a máxima bíblica e calvinista da seleção de alguns escolhidos em meio a muitos chamados:

Os novos processos não estabelecem uma formula de ferro que obrigue todos a dar os mesmos passos do mesmíssimo modo [...] a marcha accomoda-se á capacidade e idiosyncrasia de cada um. Tanto o mais talentoso como o menos intelligente deve adquirir bom methodo de trabalho e investigação [...] (ESCHOLA AMERICANA, 1899, p.1)

O método intuitivo, que empregava holisticamente competências, habilidades, sentidos e capacidades mentais e intelectuais, era a estratégia metodológica usada pelos protestantes para atender as peculiaridades de cada aluno, tomando como certo que somente alguns se sobressairiam, ainda que na propaganda da escola, esses poucos dissessem respeito ao universo da comunidade mackenzista.

\subsubsection{Prospectos da Eschola Americana/Mackenzie College}

Os Prospectos configuram uma espécie de cartilha com orientações sobre o funcionamento da instituição como um todo: internato ${ }^{65}$ e externato, Kindergarten, cursos primário e secundário, oficina de trabalhos manuais, curso normal e cursos superiores. Assim como as cartas sobreditas, esses prospectos foram assinados por Horace Lane. Neles se encontram informações detalhadas sobre os preços das mensalidades, prazos para matrículas, pagamentos e período letivo. Também são apresentados os programas de alguns cursos, bem como a grade letiva, corpo docente, material didático utilizado e regras de conduta para os alunos.

Como propaganda de suas atividades e como forma de mostrar a existência ou construção de uma comunidade coesa, traz fotografias dos prédios, de

65 O Internato feminino foi criado em 1874 e o masculino foi construído a partir de 1885, mas desde 1880 a Escola Americana recebia alunos de outras províncias (SANTOS, 2010, p.73). 
laboratórios e de estudantes. Considerando que a fotografia é "um poderoso instrumento para a veiculação das ideias e da consequente formação e manipulação da opinião pública" e que o fotógrafo "seleciona o assunto em função de uma determinada finalidade/intencionalidade" (KOSSOY, 2009, p.187), pode-se afirmar que a fotografia do grupo de estudantes é emblemática da comunidade Mackenzie, no sentido de que congrega público heterogêneo nas faixas etárias, gênero, origem e formações. É uma microcomunidade que representa a macro, a cidade paulista que naquele momento era uma sociedade marcadamente plural em sua origem e com comportamentos variados.

Figura 6: Estudantes e professores do curso superior do Mackenzie em 1905

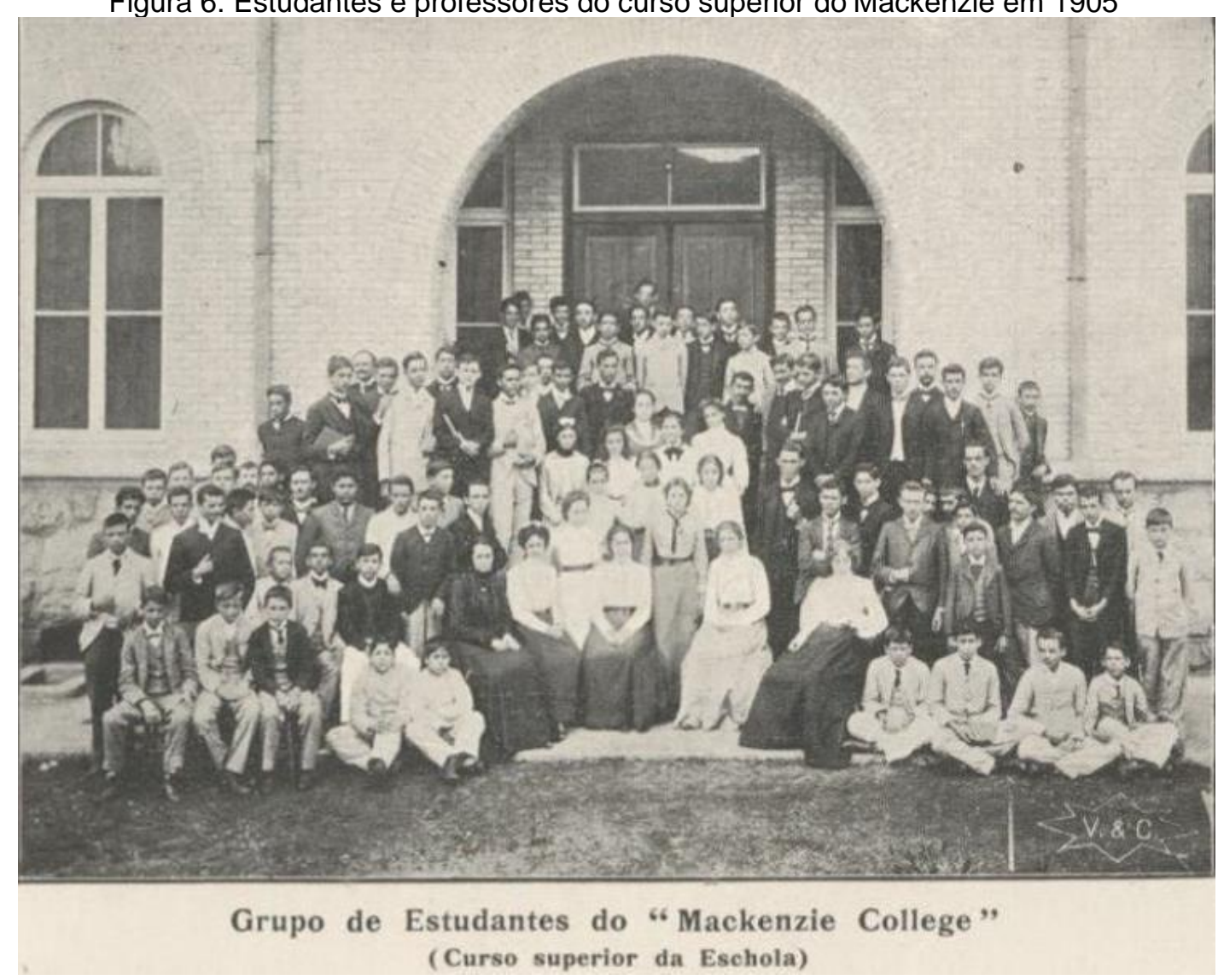

Fonte: Prospecto do Mackenzie College (1905)

Os homens não portam nem carregam em suas mãos um chapéu, mas alguns poucos, reverberando a reiterada máxima bíblica calvinista, seguram firme uma bíblia sinalizando os escolhidos do chamamento. As vestimentas não são uniformes em suas cores. Há casos em que o terno é claro e a calça escura ou o contrário. As 
saias das mulheres também não trazem um único tom. As gravatas são de diferentes tipos. A postura também não é única: homens em linha reta ou curva, braços para trás, caídos lateralmente ou na frente do corpo, mãos soltas, cruzadas ou dentro do paletó. Meninos em pé ou sentados em bancos ou no chão, quase dispostos à vontade. Essas posturas longe de serem rígidas, e menos ainda aleatórias, propagandeiam a flexibilidade da proposta da Escola Americana que vinha quebrar alguns padrões de comportamento, com a implementação da escola mista, o fim dos castigos e a prática de exercícios físicos, por exemplo. O alinhamento das figuras acompanha o desenho arquitetônico do prédio que as abriga de forma a, simultaneamente, comungar o público plural e expandir ou dar vida à simbologia que está nas bases da construção do edifício: o colégio Mackenzie, cujos tijolos são expostos no interior de uma arcada, sinalizando a formação educacional - tijolo sobre tijolo - caminho sólido para o acesso ao vestíbulo, tomando como contraponto à Academia de Direito do Largo de São Francisco, locus intelectual mais prestigiado em São Paulo. ${ }^{66}$

\subsubsection{Discursos de paraninfos e oradores}

Foram escolhidos para exame 6 discursos de paraninfos de formatura dos cursos de Engenharia e de Ciências Comerciais publicados na Revista de Engenharia. Coletaram-se também discursos de formandos, identificados como oradores oficiais da Colação de Grau de cursos superiores. Os discursos de paraninfos e dos oradores oficiais são relativos ao período que vai de 1915 a 1923.

Discursos de Paraninfos:

- Miguel Arrojado Lisboa - A instrucção scientifica e o caracter (Escola de Engenharia do Mackenzie College - 1915). Nasceu no Rio de Janeiro em 1872. Geólogo e engenheiro de Minas e Civil pela Escola de Minas de Ouro Preto (1894), foi diretor da estrada de ferro Central do Brasil.

- Dr. Rudolf Oscar Kesselring - (Escola de Engenharia do Mackenzie College 1916), engenheiro nascido em Florianópolis (1872), está entre os engenheiros brasileiros responsáveis pela construção da ferrovia Madeira-Mamoré, na Região

${ }^{66}$ A faculdade de Direito do Mackenzie seria inaugurada somente em 1955 (GARCEZ, 2004, p.243). 
Norte, entre 1907 e 1912; foi superintendente da Sorocabana Railway de 1915 a 1919.

- Dr. Arthur Motta - (Escola de Engenharia do Mackenzie College,1918), diretor da Repartição de Águas e Esgotos de São Paulo de 1906 a 193667.

- Isaltino Costa - (Ciências Comerciais do Mackenzie College, 1922).

- Christiano Stockler das Neves - (Escola de Engenharia do Mackenzie College, 1922). Nascido em Casa Branca (1889), estudou na Escola Politécnica de São Paulo e foi docente da Escola de Engenharia e fundador do curso de Arquitetura do Mackenzie College. Projetou a Estação Júlio Prestes, a Estação da Estrada de Ferro Sorocabana e a Estação da Luz.

- Dr. Frederico Vergueiro Steidel - (Ciências Comerciais do Mackenzie College, 1923). Nascido em 1867, era filho de banqueiro e ocupou a cátedra de Direito comercial da Academia de Direito do Largo de São Francisco, SP.

Saudação e discursos de oradores oficiais (formandos):

- Saudação feita pelo Dr. Mario Prado (1916);

- Dr. Heitor de Vargas Cavalheiro (1915);

- Dr. Ricardo Medina Filho (1916);

- Snr. Astor Azevedo - Turma de engenharia de 1918;

- Snr. Megalvio Rodrigues - Turma de engenharia de 1919.

Os discursos foram proferidos por alunos, ex-alunos, professores e convidados da Escola Americana em formaturas dos cursos de engenharia e ciências comerciais do Mackenzie College, publicados nas revistas dos alunos ${ }^{68}$,

\footnotetext{
${ }^{67}$ Correio Paulistano, 9/11/1920 - anúncio de Colação de Grau do Mackenzie College.

68 As revistas de Engenharia, Progresso e Avatar são publicações de associações estudantis do Mackenzie, apresentando características semelhantes entre si. Trata-se de revistas científico-literárias nas quais se encontram textos como artigos técnico-científicos, poesia, contos, crônicas, artigos sobre curiosidades, atualidades e história, além de informações sobre o cotidiano acadêmico dos Mackenzistas.
} 
vêm precedidos de uma notícia do evento, trazendo nomes de convidados ilustres e atividades como entrega de diplomas, visitas a exposições e a diversos estabelecimentos da capital.

A notícia, aparentemente singela, do oferecimento de um banquete de 20 talheres, na Rotisserie Sportman para a recepção dos hóspedes, recupera a função do banquete como cenário para a exposição "de aventuras passadas ou a profecia de conquistas futuras" (TEIXEIRA, 2011, p.67), o que aqui se faz por meio do discurso. Com efeito, à mesa em forma de $\mathrm{T}$,

"Ao champagne, falou o Snr Dr. João F. de Camargo e Silva, que, em nome de seus collegas, num bellissimo e eloquente discurso offereceu um mimo a s. excia - o paranympho". (REDACÇÃO, 1915, p.55) ${ }^{69}$

Em seu discurso, o orador oficial - Dr. Heitor de Vargas Cavalheiro discorreu sobre as funções e a importância da engenharia, historicizando-a, e procurou justificar a escolha do paraninfo, engenheiro de minas e civil, legitimando as atividades acadêmicas do Colégio Mackenzie:

"De intenso jubilo nos achamos possuídos, com a presença do nosso illustre Paranympho o Dr. Miguel Arrojado Lisbôa. Este nome sempre foi por nós pronunciado com respeito, como soem ser os dos homens de valor, no civismo, na sciencia e no trabalho impoluto e desinteressado.

Escolhendo-vos, illustre Paranympho, outro desejo não nos guiou, que não fosse o de ouvirmos de vossa autorisada competência, as palavras salutares e de animo, que sempre cabem ao Paranympho proferir em occasiões como esta, e que brilhantemente proferistes.

Queríamos a paranumphar o acto da nossa formatura, um engenheiro de solido valor, que fosse simultaneamente um profissional acatado e um scientista consummado". (CAVALHEIRO, 1915, p.67)

Em tom laudatório e ufanista, repletos de advérbios e adjetivações, os discursos versam sobre as dificuldades e os atrativos oferecidos pelas carreiras dos

\footnotetext{
${ }^{69}$ Agradecimento especial à Priscila Barbosa Ribeiro pelo alerta à importância do banquete. Comunicação pessoal.
} 
recém-formados, e, além disso, apresentam um panorama do momento histórico e social vivido pelo Brasil no início de sua experiência republicana.

Influenciados pela retórica clássica, esses discursos - que se enquadrariam naquilo que Aristóteles chama de "gênero epidítico" - tendem a seguir um padrão formal pré-estabelecido, algo aproximado do modelo greco-romano que apresentava partes que compunham o discurso (sobretudo a dispositio que diz respeito à organização interna do texto). Ademais, chamam a atenção pelo tom veemente de seus oradores - em geral intelectuais conhecidos da época - que versam sobre a herança e a missão de estudantes, intelectuais, políticos, religiosos entre outros na expansão da ordem e do progresso civilizatório nesse ambiente marcado pela instabilidade política e pela miséria material e intelectual da maioria da população:

Meus caros collegas, ao vosso paranympho conferis uma honra excelsa [...] eu venho principalmente dar-vos a lição que vos ensinará a julgar-nos amanhan, a nós os vossos maiores em edade, aos vossos mestres. Hoje, aqui, representaes de facto a geração que nos vae succeder, a herdeira dos thesouros incessantemente enriquecidos que nos transmittiram os nossos avós através dos millenios imcommensuraveis. (LISBOA, 1915, p.56)

Constantemente ressoam aqui e acolá fortes apelos ao auditório em prol de valores morais tradicionais que afirmariam o ethos socialmente conservador e, ao mesmo tempo, tecnologicamente progressista da elite cafeeira que investia muito dinheiro para industrializar a cidade:

A classe que assimila a cultura forma a mais elevada "elite" de uma nação e é nella que se deve consubstanciar os seus ideaes. A formação das elites directoras é uma das consequencias do desenvolvimento da acção collectiva. (LISBOA, 1915, p.65)

O sentimento nacionalista, a fé cristã, a doutrina positivista em voga, a exaltação das máquinas advindas da "Grande América" e da Europa, a eugenia e a higienização dos centros urbanos, além da instrução pública como meio de controle das massas são alguns dos ideais civilizatórios que eram propalados nesses discursos, muitas vezes, por meio de citações diretas provenientes de pensadores da época como o biólogo evolucionista Thomas Huxley e o filósofo positivista 
Auguste Comte, sinalizando que o Mackenzie estava no mesmo compasso da ciência moderna.

\subsubsection{Revista de engenharia}

As 21 edições que compõem a Revista de Engenharia do Mackenzie College, de 1915 a 1920, trazem um vasto conjunto de textos técnicos sobre ciência e tecnologia industrial, envolvendo áreas do conhecimento como a física, a química e a matemática. Esses textos foram escritos, em sua maioria, por alunos, ex-alunos, professores dos cursos e por especialistas brasileiros e estrangeiros convidados.

\subsubsection{Revista Progresso}

A revista Progresso aponta para uma tendência simbolista, parnasiana — em que se leem escritores como Raimundo Correia —, ademais, boa parte da produção literária da revista é feita por seus próprios colaboradores, em geral, alunos dos cursos de Letras e Ciências históricas, Ciências comerciais e Engenharia.

\subsubsection{Revista Avatar}

A revista Avatar apresenta, como já foi dito, muita semelhança com a Progresso, publicando escritores como Olavo Bilac, Coelho Netto e Machado de Assis, além das produções realizadas pelos próprios mackenzistas. Todavia há em Avatar uma forte inclinação ao sentimento nacionalista e a assuntos de cunho militar, talvez devido à existência, nesse momento, de uma companhia de guerra no Mackenzie regida por instrutores militares na qual os alunos treinavam para eventualmente servirem à pátria numa situação bélica. $O$ esporte também ganha destaque nessa revista que dedica várias seções a esse assunto.

As revistas constituem outra forma de mostrar a comunidade mackenzista e sua coesão interna, além de integrá-la à comunidade mais ampla, por meio da escrita de especialistas brasileiros e estrangeiros. 


\subsection{Estratégias de referenciação: a perspectiva Mackenzista}

O estudo da referenciação nos discursos de autoridades proferidos pelo diretor, paraninfos e oradores dos cursos do Mackenzie no entresséculos XIX-XX é apropriado para observar as construções de sentido que essa comunidade procurou compor como estratégias para legitimar suas atividades em uma sociedade de longa tradição católica. Como vimos na seção anterior, uma análise superficial de parte do corpus mackenzista nos possibilita apreender as situações histórica e social observadas em São Paulo no momento que o Mackenzie se afirmava, linguisticamente e simbolicamente, naquela sociedade. Essa conjuntura the era favorável no que concerne à possibilidade de se unir a uma modesta multiplicidade de vozes presente no seio da elite paulistana reinvindicante de modernização e progresso para si mesma. Por outro lado, a dificuldade em se livrar de amarras arcaizantes e autoritárias que prendiam essa mesma elite, provenientes de um passado lastreado pela escassez e precariedade de processos de educação formal e pela escravidão brutal, exigia exímias habilidades de construir uma imagem positiva por parte da comunidade Mackenzie.

Para tal estudo, utilizamos a definição de referenciação como "processo de construção de um caminho ligando diferentes denominações aproximadas que não são excluídas pela última escolha" (MONDADA; DUBOIS, 2013, p.30). Essa instabilidade de planos referenciais se deve às versões intersubjetivas que modificam os descritores:

[...] o processo de produção das sequências de descritores em tempo real ajusta constantemente as seleções lexicais a um mundo contínuo, que não preexiste como tal, mas cujos objetos emergem enquanto entidades discretas ao longo do tempo de enunciação em que fazem a referência. $O$ ato de enunciação representa o contexto e as versões intersubjetivas do mundo adequadas a este contexto. (MONDADA; DUBOIS, 2013, p.34)

É necessário observar que o processo de referenciação é uma atitude colaborativa e, nesse sentido, é construído por diferentes atores que apreendem a realidade não como etiquetagem, mas como construção de sentido. (KOCH; MARCUSCHI, 2006; MONDADA; DUBOIS, 2013)

Essa definição de referenciação é, de certo modo, o correlato linguístico dos símbolos e de seu conteúdo cuja compreensão pode auxiliar a desvelar o imaginário 
social. A atitude colaborativa do processo de referenciação se aproxima da ideia de que a relação entre dois objetos ou entre duas imagens depende da negociação e da eficácia política depreendidas de uma comunidade de imaginação, ou comunidade de sentido (CARVALHO, 1990).

Partindo da ideia de que por trás das expressões nominais relacionadas a "escola" há uma mobilização simbólica, pretendemos, por meio do estudo da referenciação dos discursos, depreender as negociações de cunho valorativo e ideológico do elemento estadunidense e, consequentemente, da religião protestante que vão sedimentando a comunidade mackenzista por meio da construção de seu ethos e de seu lugar nas teias que configuravam a sociedade paulista.

Para compreender um pouco a maneira como a instituição Escola Americana / Mackenzie College se referia a si mesma e, deste modo, construía seu ethos perante a sociedade paulistana, analisaremos uma pequena amostra das Cartas aos Paes e dos Discursos de paranymphos supracitados. Além disso, verificaremos quais argumentos e imperativos eram utilizados para legitimar a instauração e o modus operandi do Mackenzie em São Paulo.

A escolha das Cartas aos Paes, prospectos e discursos de alunos e paraninfos está relacionada à recepção que se dava a esses gêneros discursivos. Supõe-se que seus leitores extrapolavam os limites do Mackenzie, sendo eles pais de alunos, jornalistas, autoridades governamentais, ou seja, a elite paulistana de uma maneira geral, além dos próprios alunos e professores desse estabelecimento.

\subsubsection{A referenciação no prospecto de 1893}

O prospecto de 1893 traz entre parênteses o termo "Instituto de S. Paulo" como subespecificação da Escola Americana e o ano de sua fundação — 1870. As informações sobre a organização da escola são fornecidas sob o título Condições Hygienicas, correlacionando o processo de higienização ambiental com o social, com o qual a instituição pretende colaborar:

ESCOLA AMERICANA

(INSTITUTO DE S.PAULO)

FUNDADO EM 1870

$\overline{\text { Condições Hygienicas }}$ 
Collocado no planalto mais saudável do império e possuindo edifícios pråprios, construídos especialmente para INTERNATOS e AULAS e arranjados segundo as regras da moderna sciencia sanitária, este estabelecimento offerece para a saude dos alumnos garantias que não se acham no litoral.

Comprehende-se este estabelecimento de instrucção primaria, secundaria e superior, dois internatos e um externato a saber:

INTERNATO PARA MENINOS - Rua de D. Maria Antonia, Consolação.

(Com os arrabaldes mais apprazíveis da cidade acerca de um kilometro do Externato.)

INTERNATO PARA MENINAS - Rua de São João n.71

(Casa construída e montada com todos os acessårios modernos.)

EXTERNATO MIXTO - Rua de S. João, Esquina da do Ypiranga (PROSPECTO, 1893, p.1)

Ressignificada como "Instituto de São Paulo", a Escola Americana é posta como um produto da sociedade paulista e, como tal, reúne as melhores condições higiênicas, por ser sediada no "planalto mais saudável do império", ou seja, no bairro nobre de Higienópolis, longe das intempéries vincadas no litoral e da febre amarela que assolava o interior. Lido na conjuntura das discussões a respeito da mestiçagem brasileira, o prospecto parece se filiar à posição euclidiana ${ }^{70}$ que via no mestiço do interior um indivíduo "retrógrado", mas "não um degenerado" (SEVCENKO, 2003, p.243), passível, portanto, de domesticação/conversão, de modo que a sociedade paulista parecia reunir as condições propícias para a absorção da sofisticação técnica propagandeada pelos presbiterianos.

O conjunto das atividades é subsumido pelo termo "estabelecimento" que, além de englobar os sistemas de internato e externato, cria a integração entre instrução primária, secundária e superior, e a coeducação de ambos os sexos, pois as aulas são mistas e ministradas no externato, lugar de reunião dos alunos internos. A recategorização da Escola Americana como "estabelecimento" no prospecto é emblemática da nova pedagogia que procura pôr em vigor o ensino conjugado para ambos os gêneros, a homogeneização de regras para os diferentes cursos e o ensino graduado. Ecoando a ideia de especialização em algum produto ou ferramento, "estabelecimento" aqui, portanto, deve ser entendido como

\footnotetext{
70 Sevcenko (2003) opõe o mestiço de Euclides da Cunha encontradiço no interior do país aos do litoral, a quem, seguindo Foville, chama de "mestiços histéricos".
} 
instauração de nova pedagogia que se desenvolve nos dois eixos: se verticaliza nas séries escolares e se horizontaliza na oferta de cursos.

O mesmo prospecto informa sobre o ensino moral e religioso, com a especificação do viés evangélico: "As Escripturas Sagradas tem o lugar de honra como fonte pura da verdade, e os dez mandamentos da Lei de Deus, são a norma do ensino moral". Segue-se a informação da obrigatoriedade do "estudo da physiologia, necessário à conservação da saúde, ao desenvolvimento physico e à formação de costumes puros" para todos os alunos. Além dos cursos regulares, o estabelecimento contempla o curso de estudo, estudos preparatórios para as diferentes academias e anuncia a criação do curso normal, dedicado ao "ensino prático da pedagogia".

Quanto à disciplina, espera-se que os alunos a prestem "de boa vontade e sem aviltamento", pois "os castigos corporaes são absolutamente prohibidos em todas as repartições do estabelecimento", ou seja, em todas as instâncias de ensino. Apesar de o anúncio do veto aos castigos corporais ser bastante significativo na Escola Americana (BRUNO, 1954, p.1269) - a varada, o puxão de orelha, o bolo de palmatória - alguns professores, em desrespeito às disposições internas, lançavam mão dos tais castigos. Sophie Miller Capps relata que a professora de francês "sapecava nas cabeças dos meninos" uma vara comprida e a batia nas cadeiras para assustar as meninas. Em outro episódio, uma professora substituta "despejou o chá pela boca e vestido" de uma interna que se recusara a tomá-lo71.

A considerar o processo de referenciação no prospecto de 1893, a Escola Americana é um instituto paulista que estabeleceu o ensino por via de uma pedagogia nova - aulas mistas e graduadas - em um conglomerado que, pela assinatura do diretor, Horace Lane, emula o sistema estadunidense dos colleges.

Gradativamente, houve uma mudança nos quadros de referência que reverberava os deslizamentos socioculturais pelos quais a instituição passava ainda no período do regime monárquico. Criada pelos Chamberlains para atender "as crianças não-católicas [que se achavam impossibilitadas] de frequentar as escolas públicas por questões de intolerância religiosa" (BRUNO, 1954, p.1270), a escola

\footnotetext{
${ }^{71}$ Revista da Associação dos antigos alunos do Mackenzie, São Paulo, 1970, apud PRADO,
} (1999). 
recebeu um número crescente e heterogêneo de alunos ao longo dos anos, marcadamente quanto à nacionalidade paterna:

Tabela 1: Alunos pela nacionalidade paterna (1875-1885)

\begin{tabular}{l|l|l|l|l|l|l|l|l|l|l|l}
\hline País / ano & $\mathbf{1 8 7 5}$ & $\mathbf{1 8 7 6}$ & $\mathbf{1 8 7 7}$ & $\mathbf{1 8 7 8}$ & $\mathbf{1 8 7 9}$ & $\mathbf{1 8 8 0}$ & $\mathbf{1 8 8 1}$ & $\mathbf{1 8 8 2}$ & $\mathbf{1 8 8 3}$ & $\mathbf{1 8 8 4}$ & $\mathbf{1 8 8 5}$ \\
\hline Brasil & 42 & 46 & 85 & 145 & 157 & 122 & 179 & 222 & 170 & 244 & 231 \\
Alemanha & 34 & 39 & 23 & 13 & 4 & 5 & - & - & 12 & 4 & 1 \\
E.U.A. & - & - & 3 & 14 & 6 & 4 & - & 7 & 9 & 1 & 7 \\
Inglaterra & - & 1 & 6 & 5 & 4 & 2 & 1 & - & 3 & 2 & 7 \\
Portugal & 2 & 1 & 3 & 18 & 21 & 9 & 1 & 2 & - & 1 & 5 \\
Itália & 1 & 1 & - & 1 & 3 & 2 & 1 & 2 & 11 & 6 & 11 \\
Hungria & 11 & 10 & 7 & 8 & 6 & 13 & 5 & 19 & 15 & 6 & 7 \\
\hline
\end{tabular}

Nos primeiros anos é mais forte a presença de alunos cujos pais eram de nacionalidade estrangeira, muito provavelmente porque também atendiam aos protestantes de imigração, mas a partir de 1877, apesar de continuar a ser marcada como plural, a escola é procurada por um público marcadamente brasileiro, criandose um novo espaço social.

Além da presença de grupos nacionais, o quadro revela a procura da escola, como assinala Ribeiro (1981), por indivíduos de nacionalidades reconhecidamente católicas, como é o caso dos portugueses e dos italianos que eram, possivelmente, imigrantes republicanos expulsos de seus respectivos países por pressões ideológicas. O que era totalizante - as crianças não-católicas - passou a ser uma parcela da população. Essa reconfiguração da paisagem social exigia uma reformulação do quadro de referência que the fornecesse coerência orientacional (CERTEAU, 2011). O nome Instituto de S. Paulo, além de "nacionalizar" as atividades da Escola Americana, integralizava o público alvo originário de diversos países, e não somente dos EUA. 
Pluralizado o alunado, a alteridade se insinuava também pela distribuição de bolsas de estudo. A esse respeito, a análise da religião dos pais de alunos em livros de matrículas de 1890 revelou a presença maciça de católicos (287/447), dos quais apenas $15 / 126(11,96 \%)$ eram bolsistas, pois o grosso das bolsas de estudo estava concentrado nas mãos dos filhos dos missionários presbiterianos e dos filhos de professores e/ou funcionários da escola (PRADO, 1999, p.58), seguindo a recomendação do Board of trustees of New York de atribuir bolsas a candidatos ao ministério evangélico (GARCEZ, 2004, p.67).

A clivagem no protestantismo ocorrida no primeiro Sínodo, em 1879, de que deriva a Igreja Evangélica Brasileira é mais um elemento a ser considerado no conjunto de mudanças operadas no locus presbiteriano paulista, deixando marcas nas práticas sociais do grupo que gere a Escola Americana, como se colhe na elasticização do quadro de referências dos anúncios e prospecto de 1886, o qual oscila entre Escola Americana, um instituto paulista e Instituto Paulista.

Em anúncio ${ }^{72}$ veiculado na Revista de Engenharia do Mackenzie College, a partir de 1915, período em que a regência sai das mãos do diretor Horace Lane para as do presidente $\mathrm{W}$. Waddell, colhe-se mais uma mostra de referências à Escola Americana, por ocasião do recebimento do legado de John Mackenzie para a criação do instituto de engenharia: os diferentes cursos estão subsumidos ao "Mackenzie College", recategorizado como "Academia do tipo americano", vinculado à Universidade de Nova lorque:

\section{Mackenzie College}

Academia do typo americano pertencente á Universidade do Estado de Nova-York

\section{LETRAS}

Offerece 5 cursos:

SCIENCIAS

ENGENHARIA CIVIL

ENGENHARIA ELECTROTECHNICA

E CHIMICA INDUSTRIAL

Mantem debaixo do seu cuidado: um

CURSO DE PREPARATORIOS de 4 annos, dividido em duas secções: uma inferior, de 2 annos, e uma Superior, também de 2 annos; e um

CURSO COMMERCIAL, de 3 annos, dos quaes o $1^{\circ}$. é annexo ao Curso Inferior de Preparatorios.

A ESCOLA AMERICANA, annexa ao College, tem um curso

72 Revista de Engenharia do Mackenzie College, Orgam dos Academicos, Anno I, n.4, dez. 1915; Anno II, no.8, dez. 1916; Anno V, no. 18, abril 1919; Anno VI, no. 21, junho 1920. 
de 7 annos principiando com as primeiras letras.

Para facilitar morada aos estudantes de fora, existem um internato para moças e meninas e dois para moços e meninos. $[\ldots]$ Para prospectos e mais informações dirigir-se ao Presidente W.A. WADDELL
Rua D. Maria Antonia, 79
S. PAULO

De acordo com o anúncio, o Mackenzie College oferecia cursos superiores (Letras, Ciências, Química e Engenharia), preparatórios, para além do curso Comercial e a Escola Americana. Se no anúncio de 1886, a Escola Americana era um conglomerado que se espelhava no sistema americano de ensino, o anúncio acima a realoca como um braço do complexo educacional rebatizado de Mackenzie College, o qual não se espelha, mas "pertence" à Universidade do Estado de Nova lorque.

A recategorização Mackenzie College e o seu vínculo com Nova lorque, ao mesmo tempo em que ilustram atitudes imperialistas, satisfazem "o desejo de ser estrangeiros" que paira sobre a sociedade exibicionista e "sedenta de modelos de prestígio" no período republicano (SEVCENKO, 2003, p.51) que importa figurinos, móveis, comportamento, lazer e títulos universitários, dentro da atmosfera de hierarquização maniqueísta, opondo o progresso a formas nacionais de resistência.

Em comparação com o quadro do alunado das duas primeiras décadas, nos últimos anos do século XIX a escola apresenta índice de crescimento do número de alunos de línguas inglesa e alemã (estadunidenses, ingleses e alemães):

Tabela 2: Alunos por nacionalidade:73 1896 a 1899

\begin{tabular}{c|c|c|c|c}
\hline País & 1896 & 1897 & 1898 & 1899 \\
\hline Brasil & 358 & 379 & 364 & 339 \\
Alemanha & 34 & 46 & 45 & 48 \\
E.U.A. & 12 & 14 & 17 & 18 \\
Inglaterra & 11 & 12 & 10
\end{tabular}

73 Quadro composto pelas informações extraídas das Cartas aos Paes. As cartas anteriores a 1896 não trazem especificações sobre a nacionalidade paterna dos alunos. É possível que o crescimento da pressão sobre a Escola Americana tenha levado o diretor a mostrar que atendia um público plural e não apenas estadunidense. 


\begin{tabular}{c|c|c|c|c} 
Portugal & 36 & 20 & 26 & - \\
Itália & 19 & 26 & 33 & 38 \\
França & 16 & 14 & 11 & 14 \\
Diversos & 15 & 17 & 16 & 17 \\
\hline Total & 501 & 528 & 522 & 486 \\
\hline \multicolumn{2}{|c}{ Fonte: Eschola Americana (1896, 1899) }
\end{tabular}

O Mackenzie começava a se destacar, também, por certa tradição cultivada ao longo das décadas entre ex-alunos e seus filhos:

Após estes 29 annos de persistentes esforços e não pequenos sacrifícios, - já na segunda geração, pois temos entre os alumnos de hoje não pequeno numero de filhos de ex-alumnos, - é que podemos ver completada a organização dos nossos cursos... (ESCHOLA AMERICANA, 1899, p.1)

A vasta procura por vagas e pelo método estadunidense de ensino por diversos segmentos étnico-sociais que movimentavam o verdadeiro "caldeirão cultural" em que se transformou São Paulo naquele entresséculos, somada à certeza de continuidade dos trabalhos educacionais dessa instituição que já se achava na segunda ou terceira geração, contribuiu para sedimentar o status quo do Mackenzie que já fazia parte da paisagem paulistana seja pela absorção de imigrantes, seja pela construção do "campus"74, cujos prédios se destacavam por apresentarem uma forma arquitetônica tipicamente estadunidense, com tijolos e madeiramento à vista, grandes vidraças e vestíbulos centrais.

${ }^{74}$ Essa palavra não aparece nos registros da Escola Americana/Mackenzie College. 
Figura 10: Dormitório do Mackenzie College construído entre 1904 e 1905

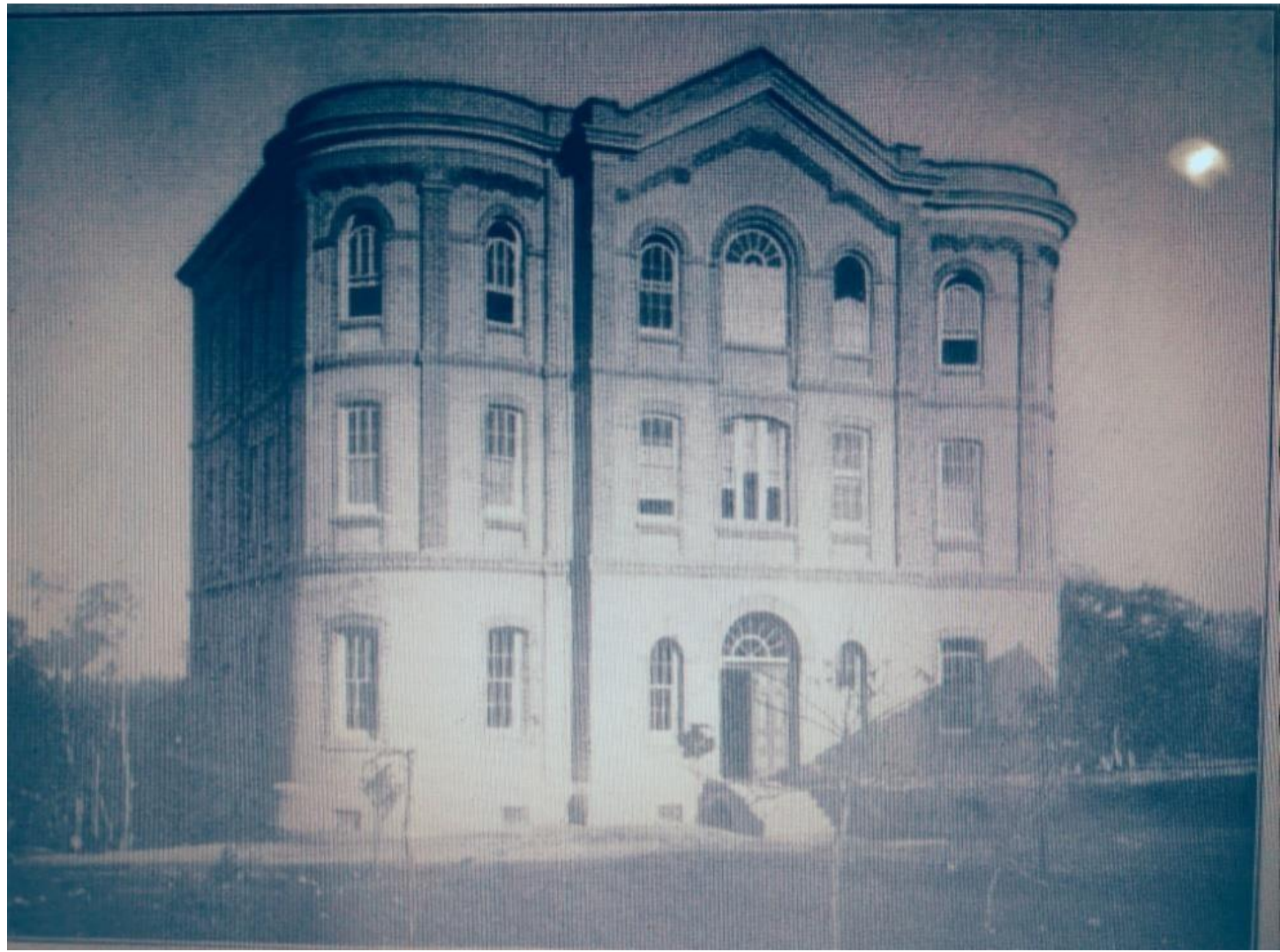

Fonte: Prospecto do Mackenzie College (1905)

Por fim, o estudo da referenciação nos prospectos aponta a instabilidade descritora entre Instituto de S. Paulo e Escola Americana, resolvida por Mackenzie College, a partir do agraciamento do legado deixado por John Mackenzie e da sua vinculação à Universidade de Nova lorque. Essa solução referencial opaciza a Escola Americana, que é colocada como um apêndice (remetendo à escola primária) de um complexo educacional com cursos superiores que passa a ser nomeado como Mackenzie College.

\subsubsection{A referenciação nas Cartas aos Paes}

Algumas especificidades giram em torno de Horace Lane, autor das Cartas aos Paes e autor / organizador dos Prospectos Mackenzie. Trata-se de um médico imigrante estadunidense que tinha o português como segunda língua. É possível que tenha aperfeiçoado sua escrita por meio da colaboração de grandes professores de português da época que, inclusive, trabalharam com ele no Mackenzie como é o 
caso de Santos Saraiva (professor de latim e português nos primórdios da Escola Americana); Eduardo Carlos Pereira e Júlio Ribeiro (que, além de gramáticos reconhecidos nacionalmente, também lecionaram língua portuguesa nessa escola).

Nas Cartas aos Paes é perceptível o vislumbre por um modelo educacional voltado para a vida prática, no qual o estudante adquirisse tanto o conhecimento de "palavras" como de "coisas". Por isso, não são poucas as vezes em que Lane critica o modelo educacional imperial encontrado no Brasil, com suas técnicas tidas por ele como obsoletas, nas quais a repetição e a memorização - práticas essencialmente teóricas - tinham como objetivo exclusivamente treinar a mocidade para realizar testes oficiais e, consequentemente, ingressar nas escassas faculdades brasileiras ou nas distantes universidades europeias:

Se a eschola apenas tem por fim dar aos alumnos conhecimento de certos e determinados compendios para satisfazer certas exigencias formaes, então este conhecimento de PALAVRAS e idéas alheias talvez seja sufficiente. Nós, porém, temos seguido outro plano que visa o desenvolvimento e aperfeiçoamento do alumno, afim de habilital-o a observar e estudar por si, tornando-o mais forte, quer pelo lado moral, quer pelo mental ou physico; por isso, não preparamos alumnos para os exames de pontos. O nosso plano põe em completa subordinação a este chamado "adiantamento", tão querido dos mestres antigos que geralmente consiste em decorar compendios sem a minima comprehensão do assumpto de que tratam; procuramos reduzir ao minimo perda de tempo e de trabalho, dando a tudo quanto se faz na eschola um character educativo. (ESCHOLA AMERICANA, 1890, p.2 - grifos nossos)

Na Carta aos Paes de 1890, sob o título "Escola Americana" são expressas as propostas mackenzistas: implementação de métodos práticos em lugar da memorização; investimento na construção de edifícios largamente propagandeados pelas fotografias que acompanham os prospectos; o investimento na formação dos professores ${ }^{75}$ colocando "os methodos e processos de ensino em severa revista crítica, eliminando-se o ruim e apurando-se o que tem de bom" (ESCHOLA AMERICANA, 1897, p.1). Dentro da filosofia protestante, essas atividades são

75 A esse propósito, Rangel Pestana, que ministrou aulas na Escola Americana, assinalava que: "Não basta dar palacetes-escolas e mestres; convém forçosamente atender às qualidades dos mestres e à proficuidade da instrução. Sou pela liberdade de ensino em todos os seus graus e entendo que tanto mais científico ele se torna, quanto mais livre deve ser". A Província de São Paulo, 09 de agosto de 1889. Disponível em: http://acervo .estadao.com.br/pagina Acesso em: 05 jul 2017. 
realizadas procurando otimizar o tempo, procurando "reduzir ao mínimo a perda de tempo".

Nesse sentido, Lane ressalta o sucesso do modelo educacional dos Estados Unidos que investiram pesado na construção de prédios escolares, na produção de material didático e na valorização do professorado sugerindo a emulação dessas práticas pela Escola Americana - respeitando os traços culturais locais - postura que o coloca em consonância com os defensáveis ideais republicanos:

[...] cremos mais que nunca que é na outra América, onde durante um seculo se tem estudado por todos os lados a magna questão da educação do povo, buscando especialistas e material de toda parte, sem olhar a sacrificios de qualidade alguma, - onde a maior preoccupação dos estadistas e pensadores tem sido a eschola publica e onde se tem, sem duvida alguma, elaborado o melhor systema de educação popular que ha hoje no mundo, em relação aos fins que tem em vista, - tanto nos methodos e resultados práticos como nos edificios e material escholares, na elevada posição do professorado e na abundancia de bons compendios, que o Brazil, cujas aspirações e instituições politicas são até certo ponto analogas, achará maior copia de auxilios, podendo facilmente aproveitar as longas e dispendiosas experiencias feitas e adaptar à parte dos resultados liquidos que convem. Nesta convicção continuamos em busca do nosso ideal, quanto ás nossas escholas, seguindo o caminho que temos trilhado ha quasi um quarto de seculo, não imitando, mas adaptando à indole do povo, ás melhores tradições sociaes e ás necessidades desta America, o que ha de melhor na outra. (ESCHOLA AMERICANA, 1894, p.2)

No entender de Lane, o deslocamento do ponteiro civilizacional da Europa para a América seria uma estratégia para superar o modelo europeu de ensino cujo "resultado corresponde exactamente aos desejos dos governos, - fazer cidadãos adaptaveis ao complicado mechanismo dos systemas antigos, creando um espirito de sujeição e subordinação tão severo que chega a ser quase servil." (ESCHOLA AMERICANA, 1894, p.2). Pelo viés do diretor, era necessário abandonar a imitação randômica e aprumar o ensino às peculiaridades locais.

O exibicionismo e a apropriação de modelos europeus de prestígio (SEVCENKO, 2003, p.51) não eram o único "inimigo" que a Escola Americana viria a enfrentar. O período é também marcado por ondas nacionalistas na imprensa local e pela falta de identidade coletiva do país (CARVALHO, 1990, p.195), não sendo favorável a instituições com nomes que remetem a países estrangeiros. A sugestão 
do nome Escola Americana - e este seria o seu calcanhar de Aquiles - tinha sido dada por José Carlos Rodrigues, diretor do Jornal do Comércio do Rio de Janeiro: "Não a chamem de colégio, nem instituto e sim Escola que abrange tudo o que se pretende. [...] Proponho a denominação de Escola Americana" (GARCEZ, 2004, p.56), cujo diferencial estava na inovação da proposta pedagógica, no ensino misto e no veto aos castigos corporais. Essas inovações deviam cair no gosto da sociedade da época, sedenta que era pelo banho civilizacional vindo de fora, entretanto, a especificação da escola com o patronímico anglo-saxônico incomodava os grupos nacionalistas.

Em nenhum momento, a Escola Americana foi ressignificada como colégio, termo largamente usado para referir as escolas católicas ${ }^{76}$. Para evitar a repetição do sintagma nominal inteiro e, mais importante, a denúncia do "estrangeiro" no patronímico, a Escola Americana, sob força da conjuntura, obriga o apagamento do adjetivo para ser referenciada como Escola e, como tal, se aproxima do imaginário que estava sendo criado em torno da Escola Normal e da Escola Complementar, símbolos do novo regime político. Já mostramos mais acima a instabilidade dos planos referenciais responsável pela sobreposição de sentido a significado, tendo por efeito o entrelaçamento de Escola (Americana) e escola (pública, seja ela Escola Normal ou Escola Complementar):

O desenvolvimento e a applicação de novos methodos ao ensino primário, a confecção de compendios pelos mesmos methodos, e o preparo de novos materiaes para o ensino objectivo intuitivo, têm progredido a passos vagarosos, mas seguros. É este o trabalho mais importante, e ao mesmo tempo mais difficil da Eschola. (ESCHOLA AMERICANA, 1889, p.2)

Continuamos a ligar a máxima importância ao ENSINO NORMAL, da Eschola. (ESCHOLA AMERICANA, 1894, p.1)

\footnotetext{
76 Ressaltemos a diferença etimológica entre esses dois termos: a palavra escola tem origem na língua grega antiga, na qual significava algo em torno dos conceitos de "tempo livre", "lazer", "descanso" e "liberdade do trabalho"; "repouso"; "ócio criativo"; "ocupação de um homem ocioso", "livre do trabalho servil", que exercia profissão liberal, ou seja, ocupação voluntária de quem, por ser livre, não era obrigado a nada; escola, lugar de estudo. Aquele que tinha o tempo ocioso/livre podia dedicar-se aos estudos). Já a palavra colégio tem origem no latim, com os significados aproximados de "comunidade", "sociedade", "associação", "corporação"; literalmente "associação de colegas". (Disponível em: https://www.etymonline.com Acesso em: 23 fev 2021).
} 
De novo o director se congratula com Paes e alumnos pela continua prosperidade da Eschola... (ESCHOLA AMERICANA, 1894, p.1)

Os logares de alumnos que já frequentam a Eschola, serão guardados até o dia 6 de Fevereiro... (ESCHOLA AMERICANA, 1898, p.1)

A Eschola foi fundada em 1870, começando a funcionar regularmente em 1871. (ESCHOLA AMERICANA, 1899, p.1)

Todas as Cartas aos Paes trazem como título, em posição central, o nome Escola Americana, mas o desenho gráfico não é o mesmo ao longo dos anos. Nos dois primeiros anos (1889-1890) usa-se a fonte courier, em 1892-1893 os caracteres são próximos aos de Old English Text; de 1894 a 1899 usa-se uma fonte próxima à french script:

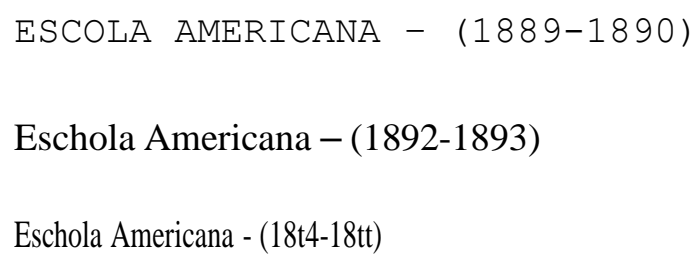

Essas letras expressam a manipulação simbólica na reorganização do imaginário mackenzista: a fonte courier em caixa alta repercutia o "estabelecimento", ou seja, a Escola Americana como um complexo educacional, já a fonte french script, cujo desenho gráfico era comum em cartilhas e livros primários, capta a sua reconfiguração, reduzida a escola primária.

À troca das fontes seguia-se o apagamento do adjetivo Americana, como mostra o quadro abaixo:

Tabela 3: Quadro referencial ao longo dos anos: Escola X Escola Americana ${ }^{77}$

\begin{tabular}{r|rrrrrrrrrr|l}
\hline & 1889 & 1890 & 1892 & 1893 & 1894 & 1895 & 1896 & 1897 & 1898 & 1899 & Total \\
\hline ESCOLA & 1 & 1 & 2 & 3 & - & 2 & 1 & 2 & - & - \\
AMERICANA & 1 & & & & & & & & & & \\
ESCOLA & 2 & 1 & 3 & 2 & 5 & 2 & 2 & 1 & 1 & 3 & 21 \\
\hline
\end{tabular}

Fonte: Eschola Americana (1889-1899)

$77 \mathrm{Na}$ primeira linha de todas as Cartas aos paes, foi eliminado o título Eschola Americana, aparecendo o ano de exercício da instituição seguido do nome isolado, Eschola (N. do A.). 
Como efeito colateral da eliminação do modificador, o nome Escola, única forma usada nos textos de 1894, 1898 e 1899, se universaliza e se "uniciza", em contraposição às demais que passam a ser lidas por suas especificações reducionistas como em Escola Normal, Escola Modelo, escolas particulares etc.

A ressignificação não causa danos aos protestantes. Sendo a escola uma das fortes propagandas do regime republicano (CARVALHO, 1990), o apagamento do adjetivo Americana, além de descolar a atividade educacional da expansão estadunidense, acaba por lhe dar amplitude, mesclando, no imaginário do local e do período, a Escola [Americana] à escola [republicana]. A esse respeito, consideremos a proximidade entre os prédios da Escola Americana, na esquina da rua S. João e rua Ipiranga, e da Escola Normal do Estado78, na Praça da República. Curiosa e coincidentemente, ou não, na Carta de 1894, ano em que se inaugura o prédio da Escola Normal do Estado, não se faz referência a Escola Americana, mas apenas a Escola!

Além da convergência nominal, a Escola Americana se "confundia" com a escola republicana por the ceder o dirigente como consultor educacional. Em 1890 Horace Lane foi convidado pelo Presidente do Estado de São Paulo, Dr. Bernardino de Campos, como consultor educacional para a implementação de uma escola pública modelo. Rangel Pestana, professor da Escola Americana, foi indicado para auxiliar no projeto de organização da Escola Normal do Estado ${ }^{79}$. A colaboração do Mackenzie com o ensino público se fez ainda pelas ações das pedagogas Márcia P. Brown e Guilhermina Loureiro de Andrade que assumiram as Escolas-modelo masculina e feminina, respectivamente, (MOTTA, 1947) como vimos no capítulo 2.

Provavelmente, as dificuldades encontradas pelos protestantes na sociedade de tradição católica, bem como os fundamentos puritanos do protestantismo, levaram o diretor a definir o que entende por eschola, colocando-a sob o regime da instituição família:

Sendo a eschola apenas uma extensão da familia, onde o director e os professores exercem sómente a authoridade que, para fins especiaes Ihes é outorgada pelos pais ou tutores: julgamo-nos

\footnotetext{
${ }^{78}$ A Escola Normal do Estado mudou-se para o prédio construído na Praça da República em 1894. (RIBEIRO, 2010, p.20)

79 Decreto no. 27, de 12 de março de 1890. (RIBEIRO, 2010, p.19)
} 
obrigados a dar, de tempos em tempos, contas dos nossos trabalhos. Juncto vae o "Boletim Semestral" feito durante o semestre. Este boletim é dirigido especialmente aos Paes, e para elle pedimos a devida attenção. (ESCHOLA AMERICANA, 1889, p.1 - Grifos nossos)

A instituição eschola é uma extensão da instituição família com a diferença de que a autoridade é outorgada aos professores e diretor pelos pais dos alunos. Relatórios e boletins semestrais fazem a "prestação de contas" das atuações dos alunos e marcam as tarefas a serem realizadas em casa, para as quais se solicita a atenção dos pais, a fim de envolver as famílias com o projeto educacional:

Os boletins, enviados no princípio de cada mez, dão conta do progresso, applicação, comportamento e frequência de cada alumno, durante os respectivos mezes. _ a marcha progressiva nos estudos de todos os mezes _ que teem sido no geral altamente satisfactoria, ver-se-á nos boletins semestraes que hoje vão pelo correio, dirigidos aos Paes, e para elles pedimos especial attenção. (ESCHOLA AMERICANA, 1896, p.1)

Logo em seguida, colocam-se os dados da aceitação da escola pela sociedade paulista. Mas não é de qualquer escola e sim da Escola Americana,

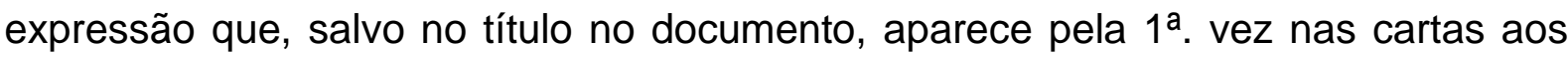
pais:

Durante o anno de 1889, a Eschola Americana tem prosperado. A matricula accusa uma frequência de 393 alumnos... (ESCHOLA AMERICANA, 1889, p.1)

A última carta é datada de 17/11/1899, ou seja, quase como comemoração dos 10 anos do regime republicano. Apesar de a Escola Americana ser ainda referenciada como Escola, já aparece o nome do propulsor financeiro da instituição, Mackenzie, ligado, porém, aos cursos superiores:

Toda correspondência relativa á matricula nos Internatos ou Externatos e no Mackenzie deverá ser dirigida ao director..... Durante as férias o director será encontrado na sua residência [ ] para todos os negocios da Eschola. (ESCHOLA AMERICANA, 1899, p.1) 
O fato de o diretor, no período de férias, se colocar disponível em sua residência é outra estratégia de criação de uma comunidade "familiar", afastando a pecha de estabelecimento comercial.

Como explicitado acima, as Cartas de 1898 e 1899 não trazem no corpo do texto o nome integral da instituição. Retém-se apenas o termo Eschola, usado não somente para dar informações positivas sobre o andamento de suas atividades como para marcar o tempo de atuação, de forma a criar uma tradição:

Folgamos em poder dizer que, em geral, a marcha da Eschola foi, durante o anno, altamente satisfactoria (ESCHOLA AMERICANA, 1899, p.1)

Termina hoje o segundo semestre de 1899 (o $58^{\circ}$ da Eschola)... A Eschola foi fundada em 1870... (ESCHOLA AMERICANA, 1899, p.1)

Após afirmar que "A Republica precisa de homens aptos, capazes de prestarem a attenção ás cousas sérias e de pôr em prática as virtudes cívicas" e que "Os tempos exigem que a sciencia seja subordinada á pratica do bem", o diretor questionava o encaminhamento dado à escola pelo estado, como podemos depreender do uso da caixa baixa de "escola" - em oposição à caixa alta que remetia ao nome próprio da Escola (Americana) - para marcar as escolas em geral, especificamente as públicas:

Qual o fim das escholas? _ Qual o resultado procurado? [...] Terá a eschola por fim simplesmente encher, por algum processo, as cabeças dos alumnos de conhecimentos formulados com mais ou menos exactidão, afim de habilital-os a tirar do mundo as maiores vantagens materiaes; um fim puramente commercial e utilitario? (ESCHOLA AMERICANA, 1899, p.2)

$[\ldots]$

Que qualidade de homens e mulheres produz a eschola? Qual o caracter delles? [...] Que leva comsigo o alumno quando deixa a eschola? (ESCHOLA AMERICANA, 1899, p.2)

A proposta de escola que o diretor da Escola Americana entendia ser importante vem na forma de pergunta retórica, seguida do perfil de homem necessário à república: 
Ou terá por fim fazer d'elles HOMENS rectos, desenvolver-lhes as forças moraes, intellectuaes e physicas, sem deixar atrophiarem-se os sentimentos religiosos e antes robustecel-os [...] fazer bons cidadãos, fortes, amantes da liberdade, obedientes ás leis e tementes a Deus?

A Republica precisa de homens aptos, capazes de prestarem a attenção séria ás cousas sérias e de pôr em pratica as virtudes cívicas. Conhecimentos sem caracter constituem um verdadeiro perigo. Os tempos exigem que a sciencia seja subordinada á pratica do bem. (ESCHOLA AMERICANA, 1899, p.2)

Veja como, no trecho acima a acepção etimológica da palavra escola é importante. Nele, a boa conduta moral, intelectual e física dos cidadãos está associada aos "amantes da liberdade", i. e., homens livres e ociosos que se dedicarão à empresas cívicas.

$\mathrm{Na}$ visão do diretor, o investimento na religião e no trabalho manual era uma das principais saídas para a formação do homem republicano. Podemos extrair daí uma crítica ${ }^{80}$ velada ao ensino laico promovido pelas escolas do governo como estratégia propagandística da Escola Americana/Mackenzie College que investiam na religião, no trabalho manual e no tratamento corporal:

O homem educado que não for bom cidadão, valente na defeza do bem, independente, com ambições viris, temente a Deus e amante da justiça, pouco valor tem para a sociedade; portanto não é possível separar o cultivo moral e religioso do intellectual. Tambem o corpo está tão intimamente relacionado com o espírito que o antigo rifão mens sana em corpore sano encerra verdade importante.

Temos, porisso, procurado addicionar ao trabalho manual nas officinas os jogos athleticos, racionalmente dirigidos para evitar abusos. (ESCHOLA AMERICANA, 1898, p.2)

Com a instituição do Mackenzie College, que se dedicava aos estudos superiores e era vinculado à universidade estadunidense, $\mathrm{o}$ isolamento do modificador Mackenzie vem marcar uma repaginação da Escola Americana, uma escola de tradição na cidade paulistana - 30 anos - conveniada com uma universidade novaiorquina que representava o progresso.

80 Essa crítica é clara no relatório de 1907: "As escolas públicas, em muitas das grandes cidades do Estado, são bem conduzidas, porém todas as referências são mal administradas. Elas simplesmente instruem, não educam [...]" (Annual Report to the Board of Trustees, 1907 apud PRADO, 1999, p.125). 
Em um primeiro momento, o nome Mackenzie College parece se associar exclusivamente aos estudos superiores, seja para internacionalizá-lo por meio de sua filiação à Universidade do Estado de Nova Iorque, seja para Ihe dar um prédio apropriado, com vistas à criação de um locus social:

O CURSO SUPERIOR funciona no internato dos meninos, emquanto não se completa o edifício do "Mackenzie College", já em construcção.

Sobre os cursos d'esta instituição, suas relações com a Universidade de Nova York e a connexão com a Eschola, daremos opportunamente os esclarecimentos precisos. (ESCHOLA AMERICANA, 1894, p.1)

Num segundo momento, o nome Mackenzie College é recategorizado como estabelecimento, um complexo educacional como campus - descritor não adotado pelo diretor — visando a integrar prédios com diferentes funções:

Os três annos do Curso Geral dos Estudos Superiores, e o curso de engenharia estão funcionando no Mackenzie College a medida que os estudantes se preparam. (ESCHOLA AMERICANA, 1898, p.1)

Resta-nos ainda elaborar os últimos passos dos cursos superiores, construir o dormitório novo para Mackenzie... (ESCHOLA AMERICANA, 1899, p.1)

À falta de espaço e de condições para a anexação da Escola Americana às escolas republicanas - ou vice-versa, pois a Constituição Republicana separava igreja de estado - os protestantes se filiam à universidade nova-iorquina como forma de pontuar sua presença na cidade que começava a ganhar cosmopolitismo. Se, porém, o anúncio trazia o pertencimento da Academia à Universidade de Nova lorque, na pena de Lane, o que havia era uma inespecificada "relação entre o estabelecimento de ensino e a Universidade do Estado de New York".

\subsection{Tessitura e referenciação no discurso do orador oficial}

Iniciamos a análise da referenciação no discurso do formando, representante da norma linguística em vigor no Mackenzie, em situação de alta formalidade. $O$ exórdio do discurso epidítico elaborado pelo orador oficial - Dr. Heitor de Vargas 
Cavalheiro - é dirigido ao público em geral, evocado, na abertura e na apresentação do paraninfo, como Exmos. Snrs. Exmas. Senhôras, e caracteriza-se pela repetição de estruturas sintáticas e pela construção do quadro referencial por meio do uso de demonstrativos, os quais permitem criar efeito de afastamento ou aproximação de lentes, obtendo, com esse mecanismo, oposição entre o mundo interno e o externo ao Mackenzie, entre os ciclos evolutivos da vida do mackenzista dentro e fora da comunidade:

Quis a benevolência dos meus prezados collegas, escolher-me para interprete dos meus sentimentos ao partirmos desta casa, onde por longos annos nos dedicamos ao trabalho,

onde por não menos longos annos preparamos a promessa do que deveremos ser.

[...]

Fecha-se hoje

Senhôres e Senhôras

o cyclo evolutivo dos nossos estudos práticos e abstratos, abre-se porém, um novo cyclo de trabalhos, o da nossa p.f. vida pratica.

Si aquelle já foi bastante fadigoso, este ainda nol-o será muito mais. Naquelle tivemos sempre ao nosso lado

quem nos guiasse,

quem nos mostrasse carinhosamente o caminho

a seguirmos,

desviando-nos o mais possível dos roteiros árduos,

evitando na medida de suas forças que esbarrássemos com um obstáculo

que nos pudesse fazer vacillar, que nos pudesse incutir o desanimo.

(CAVALHEIRO, 1915, p.66 - grifo nosso)

O aproveitamento das regras gramaticais sobre o uso anafórico e catafórico de aquele e este, respectivamente, cai como uma luva no discurso do formando, pois, ao retomar o antecedente - o sintagma complexo "ciclo dos estudos práticos e abstratos" realizados no Mackenzie - o pronome demonstrativo aparece na forma singular e, associado ao pronome indefinido em repetição e na sequência, catalisa relações equativas [naquele: Mackenzie e, metonimicamente, quem: Mackenzie] ao mesmo tempo em que evoca a máxima bíblica "Tudo posso naquele que me fortalece" (Filipenses 4:13). O cruzamento dos planos referenciais cria, como efeito 
de sentido, a equação [naquele: quem :: Mackenzie: Aquele], de modo a projetar e percolar o imaginário social do Mackenzie dentro dos valores protestantes ${ }^{81}$.

A apresentação do paraninfo, Dr. Miguel Arrojado Lisboa, em comparação com o que ocorre no exórdio, é pouco marcada pela repetição de estruturas sentenciais, ainda que se verifique a reiteração do sintagma preposicionado e da oração relativa, e a oposição dos dêiticos "aqui" e "ali" para marcar as atividades do engenheiro, tratado por "vós":

Este nome sempre foi por nós pronunciado com respeito, como sôem ser os dos homens de valor, no civismo, na sciencia e $[\ldots]$ no trabalho impoluto e desinteressado.

Como engenheiro, tendes dado as provas mais flagrantes do vosso alto saber, que de todos são conhecidas,

[..] que por todos são apreciadas.

Por quantas vezes não tendes desbravado os nossos ínvios sertões [...]

Aqui, demarcando por meio dos fosseis encontrados, os terrenos que elles caracterisam,

alli, estudando efficientemente por meio de córtes geológicos o intimo do nosso solo e subsolo...

(CAVALHEIRO, 1915, p.67)

Terminada a apresentação do paraninfo, o orador se dirige aos colegas ("Caros Collegas!") para enaltecer a profissão da engenharia e faz uso da repetição de perguntas retóricas:

Quem põe os povos civilisados em perene communicação [...]?

Quem por meio das vias de communicação desenvolve as industrias e o commercio?

Quem [...] promove o intercambio intellectual das nações?

Quem ergue a casa que habitamos, a escola em que nos edificamos?

$O$ engenheiro é a resposta.

(CAVALHEIRO, 1915, p.69 - grifos nossos)

\footnotetext{
${ }^{81}$ Marilza de Oliveira (Comunicação pessoal).
} 
O epílogo é marcado pela saudação de autoridades locais e estrangeiras, respectivamente, "Senhor Dr. Director", "Exmo. Snr. Doutor Embaixador dos Estados Unidos da América do Norte", "Dignissimo Snr. Dr. Inspector da Universidade de N. York", encerrando-se com a fórmula afetuosa "Caros Professores" e a retomada da saudação geral: "Exmos. Snrs. e Exmas. Senhôras".

No que diz respeito aos itens lexicais, há uma aparente instabilidade dos planos referenciais, como se depreende do quadro referencial, distribuído na seguinte ordem:

Quadro 6: Referenciação no discurso do orador oficial

\begin{tabular}{l|r|r|r}
\hline casa $_{1}$ & & \\
casa $_{2}$ & estabelecimento $_{1}$ & instituição $_{1}$ & \\
estabelecimento $_{2}$ & instituição $_{2}$ & \\
estabelecimento $_{3}$ & & escola $_{1}$ \\
& casa $_{3}$ & & \\
\hline
\end{tabular}

Quis a benevolência dos meus prezados collegas, escolher-me para interprete dos seus sentimentos ao partirmos desta casa ${ }_{1}$, onde por longos annos nos dedicamos ao trabalho ${ }^{82}$ (CAVALHEIRO, 1915, p.66).

Que a vossa presença venha estimular ainda mais os estudos de geologia desta casa ${ }_{2} \ldots$ (CAVALHEIRO, 1915, p.68)

Bastante penhorados, agradecemos também, ao illustre homenageado, Dr. Geo. Smith provecto lente deste estabelecimento $_{1}(\mathrm{sic}), \quad \mathrm{O}$ gentil tratamento que sempre nos dispensou... (CAVALHEIRO, 1915, p.68)

Quero me referir ao illustre e venerando Dr. Lane, o extincto fundador desta instituição ${ }_{1}$ (CAVALHEIRO, 1915, p.70)

Em bella herma, acha-se a sua memória perpetuada no espírito dos estudantes deste estabelecimento ${ }_{2}$ que o conheceram, e, no espírito daquelles que, não tendo pertencido a esta instituição 2 tiveram a dita de com elle privar. (CAVALHEIRO, 1915, p.71)

82 Nesse contexto, a palavra "casa" pode ser interpretada como alinhamento com os republicanos (Instituto Paulista) em oposição à "Casa de Bragança", representação máxima do império português que, subliminarmente, simbolizava o Império brasileiro até 1889 e suas instituições, entre elas, o Colégio Dom Pedro II (Comunicação pessoal, Marilza de Oliveira). 
Senhor Dr. Director, mil congratulações pela solida e proveitosa direcção que vindes imprimindo a este Estabelecimento ${ }_{3} \ldots$. (CAVALHEIRO, 1915, p.71)

Que todas as gerações que por esta escola ${ }_{1}$ tenham de passar, saibam se curvar diante da augusta imagem ... (CAVALHEIRO, 1915, p.71)

Exmo. Snr. Doutor Embaixador dos Estados Unidos [..] abrilhantando com a vossa egregia presença o acto da nossa despedida desta casa $_{3 .}$ (CAVALHEIRO, 1915, p.71)

Como se pode observar, em nenhum momento é referido o nome Escola Americana, Colégio Mackenzie ou Mackenzie College e em todos os casos o item nominal é precedido de um pronome demonstrativo. Embora todos os itens possam remeter à Escola de Engenharia, pois o evento comemora a formatura de seus alunos, em alguns casos as expressões nominais podem remeter ao complexo educacional, nos diferentes graus de conhecimento (primário, secundário e superior), como, por exemplo, casa e casa $_{3}$ em que a despedida parece ter como fonte a casa como extensão da família. Por outro lado, embora casą possa também remeter à casa-família, o estudo da geologia é específico da Escola de Engenharia, o que a coloca como uma primeira leitura. A leitura específica se dá para o item estabelecimento 1 (o lente homenageado pertence ao quadro de docentes da Engenharia), para o item instituição ${ }_{1}$ pelo fato de o Dr. Lane ter sido fundador da Escola de Engenharia e para estabelecimento3, pois o diretor presente está na gestão dessa mesma escola de formandos. Já no caso dos itens estabelecimento ${ }_{2}$, instituiçãon e escola1, eles parecem guardar memória do complexo educacional, acompanhando a linha do tempo marcada desde os bancos do ensino primário da Escola Americana.

Apesar de haver algumas possíveis interpretações para os itens lexicais repetidos no discurso do orador oficial, é evidente a ambiguidade na leitura desses termos. Essa ambiguidade não é aleatória, se levarmos em consideração a ausência dos nomes próprios das instituições. Mais do que assinalar a Escola de Engenharia, o orador parece ter pretendido tornar opacas as diferenças e marcar a presença dos formandos em todas as instâncias de educação mackenzista. Afinal, "em regra, criança que entra, fica até o final do curso, e os irmãos menores vêm todos, cada um 
por sua vez; daí repetir-se o nome do pai, ano após ano, nas relações de filiação83" (RIBEIRO, 1981, p.67)

\subsection{A tessitura dos discursos dos paraninfos}

Para a análise do quadro referencial escolhemos os discursos dos paraninfos Arrojado Lisboa, por ocasião da formatura da Escola de Engenharia (1915) e Vergueiro Steidel, por ocasião da formatura do curso superior de Ciências Comerciais (1923), pois são os dois únicos oradores que versam caudalosamente sobre a história e as atividades da Escola Americana e/ou do Mackenzie College.

Miguel Arrojado Ribeiro Lisboa ${ }^{84}$ (1872-1932), nascido no Rio de Janeiro, geólogo e engenheiro de Minas e Civil pela Escola de Minas de Ouro Preto (1894), foi diretor da estrada de ferro Central do Brasil e evoca em seu discurso reminiscências da construção de estradas de ferro, o Seminário da Luz e a Faculdade de Direito (ver cap.1), que, citados uma só vez no exórdio do discurso, serão o contraponto para tecer considerações sobre as propostas inovadoras da comunidade mackenzista.

O discurso do paraninfo faz saudação aos presentes na forma "Meus senhores. Meus caros collegas" e usa a $2^{\text {a }}$. pessoa do plural como forma de tratamento. Ao longo do texto, evoca os colegas evoluindo de "Meus caros collegas" para "Meus snrs., eu vos convido...", "Mas caros collegas" e finalizando com um simples "Caros collegas", como se não fosse mais necessário o uso de possessivo de 1a․ pessoa para criar proximidade, pois, ao finalizar o discurso, os formandos já haviam - com o diploma em mãos - se transformado em verdadeiros colegas do orador.

83 O irmão de Sophie Miller, Roberto Miller, formou-se engenheiro. Também estudaram no Mackenzie seus quatro filhos, um neto e um sobrinho. (PRADO, 1999, p.48)

84 Foi também fundador da Sociedade de Cultura Artística e um dos colaboradores da instalação da 1a . emissora de rádio paulista em 1923. Fonte: Revista da Faculdade de Direito. Em comemoração ao sesquicentenário da Fundação dos cursos jurídicos no Brasil. Disponível em: www.obrasraras.usp.br. Acesso: 01 nov 2019. 
A estrutura textual é permeada de construções correlatas, construções clivadas e repetições. As construções correlatas são constituídas de diferentes tipos, que vão desde as chamadas orações coordenadas aditivas às subordinadas comparativas e proporcionais (MÓDOLO, 2008; OITICICA, 1952):

As gerações humanas têm

tanto maior comprehensão da subordinação do homem á natureza quanto mais elevada a sua cultura ou maior a sua civilisação. (LISBOA, 1915, p.57)

A instrucção e a educação não sómente conduzem o homem á descoberta rápida das suas necessidades como também o ensinam a bem suppril-as. (LISBOA, 1915, p.63)

A natureza da instrucção não só deve mudar com o tempo mas também com os paizes pela razão simples de que as necessidades variam com os seus recursos naturaes. (LISBOA, 1915, p.64)

A medida que o poder do homem se eleva sobre as forças naturaes mais necessários se tornam os princípios Moraes... (LISBOA, 1915, p.65)

No ensino technico e scientifico moderno a parte material é tão importante quanto a selecção de professores e este principio está incorporado ao methodo de ensino norte-americano.

(LISBOA, 1915, p.61)

Mais do que um emparelhamento, as construções correlatas acrescentam peso a um dos pratos da balança, de modo a adicionar informações cujo sobrepeso não dispensa ou despreza o lado oposto: o homem de cultura compreende estar subordinado à natureza, mas, com instrução e educação, a domina. A instrução deve acompanhar o ritmo do tempo e se ajustar às necessidades locais. A intervenção na natureza requer a obediência a princípios morais e depende de professores bem preparados, o que a Escola Americana fornece.

As construções clivadas criam o mesmo efeito de sobrelevar uma informação, mas não coloca de forma explícita, ao contrário das correlatas, informações paralelas ao alcance do ouvinte/leitor. As construções clivadas colocam em 
evidência as práticas adotadas pela Escola Americana sem a necessidade de retomar os nomes de outras escolhas que lhe servem de contraponto:

Assim, foi antes pela subordinação ao instincto e não pelas inducções da reflexão

que tivestes a minha acquiescencia pressurosa.

É restringindo o numero [de alunos] ao compativel com o apparelhamento material que os vossos mestres querem chegar á perfeição.

É da instrucção científica que depende o desenvolvimento do trabalho technino e profissional...

Do desenvolvimento dado a essa sciencia foi que resultou, pela maior parte, a prosperidade da Allemanha e da America do Norte...

O caracter é innato mas se aperfeiçoa pelo exemplo e pela vontade. Elle sempre se impõe quando perfeito porque torna-se então uma força considerável, resiste tanto ao conceito injusto como a claque e é por elle que os homens se medem entre si no fundo das suas consciências.

É a consciência da responsabilidade que nos obriga a pensar para bem agirmos e é por esse motivo que somos obrigados a ter um ideal.

A classe que assimila a cultura forma mais elevada "elite" de uma nação e é nella que se deve consubstanciar os seus ideaes. (LISBOA, 1915, p.56-66)

O emprego das construções correlatas e das clivadas é uma manipulação sintática criadora de ritmos que suscitam relações sem que elas sejam evidenciadas nominalmente (ZUMTHOR, 1993, p.67). Todo o texto é permeado pelas duas construções de modo a provocar no ouvinte a ideia de pesos nos pratos de uma balança, evocada pela constituição de estruturas correlatas, e a adição de um peso suplementar em uma das balanças, efeito produzido pelas estruturas "é que". Naturalmente, essa sobressaliência de peso é atribuída à Escola Americana, ainda que o seu nome não seja pronunciado uma vez sequer, bem como a Academia de Direito e o Seminário da Luz - seus contrapontos - que são mencionados uma só vez no exórdio. 
As repetições também são numerosas, mas se restringem aos verbos dever e precisar e aos sintagmas nominais ou preposicionais. Os primeiros aparecem na função deôntica, apontando a necessidade e urgência da intervenção:

A natureza da instrucção não só deve mudar com o tempo mas também com os paizes [...]A instrucção scientifica deve aqui, pois, começar elementarmente na escola primaria [...]O nosso ensino, a nossa instrucção não deve pois ser a copia ou a transplantação do já usado em nações antigas [...] Devemos pois difundir a instrucção scientifica, á feição do nosso tempo e da nossa terra. [...]

A cultura é indispensável as nações porque ella determina as directrizes da actividade social e deve ser original deve ser nacional [...] É á falta de cultura que devemos a maioria dos nossos erros. (LISBOA, 1915, p.56-66)

A repetição da temática do sintagma nominal (senhor/possuidor/dono) e do sintagma preposicional ecoa a ideia de assenhoramento da riqueza natural, entre disposição e motivação para a instrução das "ciências físicas e naturais":

Qual é a instrucção mais conveniente para um paiz

muito vasto mas pouco povoado,

novo mas de recursos naturaes muito variados,

senhor da mais rica fauna terrestre conhecida,

possuidor da maior superfície florestal continua,

da flora mais original e diversa,

dos mares e rios mais piscosos de toda a terra,

dono de cadêas de montanhas de ferro,

de terrenos mineraes sortidos,

força hydraulica incommensuravel, terras e climas para todas as

culturas e para alimentar a mais variada industria pastoril?

Para um paiz dessa natureza, senhores, a necessidade máxima está na instrucção das sciencias physicas e naturaes.

É uma verdade que precisa ser

repetida,

repetida diariamente,

repetida com e sem opportunidade,

repetida por toda parte até ser comprehendida.

É da instrucção scientifica que depende o desenvolvimento do trabalho technico e profissional sem os quaes não será possível explorarmos nossa riqueza. (LISBOA, 1915, p.56-66)

O núcleo da tópica "país novo mas de recursos naturais muito variados" é retomado pela recategorização em "senhor", "possuidor" e "dono", produzindo rupturas rítmicas que exemplificam e ilustram os recursos naturais que exigem o 
investimento na instrução das "ciências físicas e naturais", fato que deve ser realçado incessantemente, o que se faz pela reiteração da síntese "verdade que precisa ser repetida". A reiteração do particípio, forma verbal que designa o aspecto perfectivo, no evento solene de formatura de alunos da Escola de Engenharia, evoca o ato performativo da reflexão de uma onda sonora.

Por meio dos vários expedientes linguísticos acima, o orador sobreleva a agenda mackenzista sem precisar lançar mão das instituições tomadas por contraponto - Academia de Direito e o Seminário da Luz - a todo instante para, a partir da alteridade, construir a identidade da comunidade Mackenzie, em período em que estava em operação a busca de uma identidade coletiva para o país (CARVALHO, 1990, p.32).

O segundo orador cujo texto tomamos para exame é Frederico Vergueiro Steidel (1867-1926), filho de banqueiro alemão (Ernesto Conrado Steidel). Nascido em São Paulo, estudou no Colégio Moretzesohm e parece ter frequentado os bancos da Escola Americana, como se pode depreender do exórdio de seu discurso (capítulo 2) e pela forma de saudar o público a que se dirige: "Caros Jovens", os quais são tratados pela $2^{a}$. pessoa do plural, e, ao longo do texto, evocados como "meus jovens amigos" e "meus velhos amigos".

O convite para paraninfo do curso superior em Ciências Comerciais do Mackenzie, em 24 de novembro de 1923, parece se justificar pelo fato de ocupar a cátedra de Direito Comercial da Academia de Direito do Largo de São Francisco, o cargo de presidência da Liga Nacionalista e por seu papel de cofundador do Liceu Franco-Brasileiro, entidade que servirá de contraponto para sustentar a importância da colaboração científica entre os países. A sua presença em sessão solene de formatura vinha legitimar as atividades mackenzistas em meio às agitações dos jacobinos, as quais vinham sendo atacadas devido ao seu nome e à sua vinculação com a Universidade de Nova lorque.

Tomando o Liceu Franco-Brasileiro como contraponto para o Mackenzie, o orador discorre sobre a entidade francesa várias vezes salientando o espírito de cooperação e colaboração entre França e Brasil, e colocando a questão na moldura que encerra o reconhecimento do valor dos diplomas estrangeiros, haja vista que o Liceu aspirava a equivalência de seus cursos ao da Universidade de Paris. Jogando 
luz no quadro (figura usada pelo orador), o diploma estrangeiro devia colocar o Mackenzie, "sucursal" da Universidade de Nova lorque, no alvo das querelas nacionalistas, motivando o orador a explicitar uma definição de nacionalismo ampla e integradora:

Notae que eu vos fallo do verdadeiro nacionalismo, tal como o comprehendem os nossos homens mais notáveis e a mocidade das nossas escolas, e não do regionalismo absurdo, ao qual se tem dado o nome de jacobinismo.

O nacionalismo não repelle a collaboração scientifica estrangeira, desde que ella não venha molestar a integridade nuclear

dos nossos sentimentos de amor á patria,

de democracia,

de integridade nacional e intangibilidade do nosso território,

da nossa língua e

da nossa historia. (STEIDEL, 1923, p.12)

Para retirar a sombra negra da afronta ao nacionalismo que deveria pairar sobre o Mackenzie, o orador faz uso da repetição para assinalar que a instituição se encontrava nos trilhos da "pátria amada salve salve":

Se eu precisasse de uma prova material de que aqui dentro se presta um justo culto ao nosso estremecido Brasil,

bastaria levantar os olhos para a nossa bandeira [...]

bastaria olhar para a farda do patriótico soldado brasileiro, vestido por alumnos que formam a garbosa Companhia de Guerra deste estabelecimento [...]

bastaria lembrar que em todas as salas de aula desta casa, o trabalho de cada dia começa pelo desfraldar da bandeira brasileira, saudada por cantos patrióticos [...]

Solemnidade de liturgia patriótica, que a Escola Americana foi a primeira a introduzir em nossas escolas...

Aqui todos são brasileiros, alguns pelo coração, outros pelo nascimento, e nem eu comprehendo que aquelle

que abrio os olhos pela primeira vez ao sol radioso deste paiz,

que balbuciou a palavra mãe no harmonioso idioma dos nossos poetas;

que uma vez contemplou a pujança das nossas florestas; verdes;

que se deixou embalar pelas ondas mansas de nossos mares do sul;

que scismou á noite ouvindo estrellas e adorando o Cruzeiro

que sentio a magestade dos nossos rios e cacahoeiras;

que admirou o valor dos nossos heroes na guerra e na paz; possa pensar em ter uma segunda patria. (STEIDEL, 1923, p.16)

O plano de organização da repetição engendra ritmos diferentes. O verbo bastaria no futuro do pretérito repetido em número de três, ao mesmo tempo em que 
anuncia a desnecessidade de efetuar os movimentos, convoca o público que performatiza os movimentos mnemônicos da lectio divina de levantar os olhos, olhar e lembrar. Por sua vez, as sete orações relativas que restringem o demonstrativo "aquelle" reverberam o sétimo dia para o descanso de Deus após o trabalho da criação do mundo e o trabalho de sete anos do pastor Jacó, que, encantado por Raquel, foi obrigado a se casar com a irmã, mas tinha ideia fixa no primeiro e único amor.

Se entendermos, com Zumthor (1993), que "é a voz e o gesto que propiciam uma verdade" e que a voz intervém no texto, podemos interpretar a série de repetições acima como estratégia de acionar gestos concretos e movimentos abstratos do orador os quais seriam acompanhados pelo público de forma a marcar a sua anuência - com a cabeça, o olhar e a mente - com o conteúdo de cada enunciado evocado.

O orador encerra o discurso clamando os formandos a cultivarem o verdadeiro nacionalismo, reconhecido e defendido pela autoridade máxima do país evocado para legitimar a definição que pretende expressar:

Cultivae sempre o verdadeiro nacionalismo, tal como o define o expresidente da Republica, o Sr. Epitacio Pessôa;

o nacionalismo que colloca o Brasil antes e acima de tudo, e o faz a divindade inspiradora de todos os nossos pensamentos;

o nacionalismo que se orgulha de ser brasileiro, e, por isso mesmo não tolera, que dentro das suas fronteiras sejamos relegados á posição de estranhos;

o nacionalismo que resguarda o carinho pela terra contra o contagio dissolvente de um cosmopolitismo desfibrado, em uma palavra Brasil,

o nacionalismo feito de amor e ternura por tudo o que é do

de zelo pelo seu nome,

de sacrifícios pelo seu progresso,

de sonhos pela sua gloria.

(STEIDEL, 1923, p.20-21)

A recorrência ternária do segmento "o nacionalismo que" seguido de definições explicativas e a repetição ternária do sintagma preposicionado, introduzidas a partir de um modelo inicial remetem ao simbolismo bíblico do número três (levantar os olhos, olhar e lembrar), conformando e confirmando as proposições 
do orador e do público, uma vez que "nas profundezas antropológicas, existe um laço vivo entre as formas rítmicas e as mnemônicas" (ZUMTHOR, 1993, p.173).

\subsection{A referenciação nos discursos dos paraninfos}

Após o desenvolvimento da tópica da humildade que toma todo o exórdio de seu discurso, o paraninfo dos formandos de engenharia, Arrojado Lisboa, discorre sobre a evolução da civilização para adentrar na organização e nas atividades do Mackenzie, referenciado pela primeira vez pelo termo "Escola", que, ao adotar o regime de "Academia Livre", "resguardou a instituição das injunções nem sempre benéficas da política", o que lhe garantiu a adoção de métodos de ensino norteamericanos:

Ainda mais, essa iniciativa notável para o nosso meio, permittiu a adopção entre nós dos methodos norte-americanos de ensino, a feição mais característica deste instituto. (LISBOA, 1915, p.59)

Dentro do quadro de referências do discurso, o método de ensino americano é uma particularidade que recategoriza a escola como instituto. Apesar de não fazer nenhuma menção explícita à Escola Americana, restringindo suas reflexões aos ensinos secundário e superior do Colégio Mackenzie, depreende-se que a ressignificação da escola como instituto que adota o método de ensino americano remete subliminarmente à Escola Americana:

Ella é a primeira formatura ostensiva da vossa Escola, e do exame attento da sua organisação se deve presumir que este facto são as primeiras folhas de uma planta destinada a ser arvore frondosa [...] Não há então aqui a preoccupação de abarrotar as salas da Escola de alumnos para a multiplicação crescente e annual dos diplomas! (LISBOA, 1915, p.61)

O isolamento do substantivo "Escola" cria uma ambiguidade referencial que não é aleatória, podendo remeter tanto à Escola de Engenharia de que tinha sido designado paraninfo quanto à escola - de planta a árvore - entendida em seu processo contínuo e gradual de construção do saber do qual deriva mais uma inovação dessa instituição de instrução cujo "espírito educador" restringe o número de alunos "ao compatível com o apparelhamento material". 
Tomando como contraponto as universidades americanas que tiveram seu início em uma "Escola - 'college' - modelada pelas inglezas de Oxford ou Cambridge" e se desenvolveram com a concentração de estabelecimentos variados como escolas, capelas, bibliotecas, laboratórios, casas de estudantes, formando um só instituto, o orador introduz pela primeira vez o nome "Collegio Mackenzie", mas, observe, não Mackenzie College:

Outro traço do Collegio Mackenzie é que elle abrange sob as mesmas regras o ensino secundário e o superior. Isso permite que a Escola de Engenharia receba alumnos com preparo adequado e sufficiente. (LISBOA, 1915, p.62)

O emprego do pronome "outro" toma por pressuposição a existência de um primeiro elemento, que, no caso, foi a exposição das universidades americanas, como se o Mackenzie fosse sua extensão ou cópia.

A recategorização de escola como "Collegio Mackenzie" se deve à inclusão do curso superior e à unificação das regras de ensino para os diferentes níveis, com ênfase na instrução científica, o que favorece o "preparo [e] suficiente" dos alunos para os cursos superiores, de que a Engenharia foi o primeiro:

A instrucção scientifica deve aqui, pois, começar elementarmente na escola primaria, porque principalmente terá poder para desenvolver o sentido de observação de criança em um meio de uma natureza tão estimulante.

$[\ldots]$

A instrucção do povo se faz por camadas e estas se aperfeiçoam até alcançarem a cultura.

$[\ldots]$

A classe que assimila a cultura forma mais elevada "elite" de uma nação e é nella que se deve consubstanciar o seus ideaes." (LISBOA, 1915, p.65)

Em uma segunda rodada, a expressão "Collegio Mackenzie" é tomada para expressar a "sua filiação á Universidade do Estado de Nova York", de tal forma que esse termo passa a referir a um só tempo o ensino, sob as mesmas regras, de diferentes níveis de instrução - o que configura a comunidade Mackenzie - e sua associação a uma universidade americana como estratégia de valorização de seu diploma e como garantia, por meio da fiscalização dos trustees, do "desvio [de seus 
fundos] para outro objecto que não o da educação", além da "rigorosa applicação do padrão universitário americano aos trabalhos escolares":

Esse instituto contem pois em sua organização preceitos muito notáveis [...] Essa preoccupação elevada de bem ensinar sem ostentações espalhafatosas é o melhor elogio que se póde fazer aos vossos mestres. Serviço algum neste país póde ser mais relevante que esse de ministrar instrucção adequada e san. (LISBOA, 1915, p.62)

A recategorização do Colégio Mackenzie como instituto insere 0 conglomerado constituído por escolas de diferentes níveis de instrução sob um mesmo regime educacional que, legitimado e assistido por uma universidade americana, garante o padrão de ensino americano.

Em suma, a estratégia de evitar nomear a Escola Americana e as instituições que lhe servem de contraponto - Academia de Direito e Seminário da Luz permite que o orador se delongue sobre as ações da Escola expressas pelas construções correlatas, construções clivadas e repetições, sem violentar a tradição, sem agredir o público que pretende atingir.

Diferente é o caso do discurso do paraninfo do curso Superior em Ciências Comerciais, Vergueiro Steidel, co-fundador do Liceu Franco-brasileiro, que tem como ponto de partida a expressão "Escola Americana" caudalosamente reiterada, pontuando a sua especialização nos ensinos primário e secundário:

...no mesmo prédio ainda alli existente, [...] levantava-se a Escola Americana, povoada de meninos, que hoje são velhos, onde íamos procurar as primeiras noções do saber [...]

Eis porque me compraz voltar de novo á modesta Escola Americana, fundada em 1870, há 53 anos, portanto, pelo bondoso Chamberlaim, "um velho de aspeito venerando" [...]

O curso de instrucção primaria e secundaria da Escola Americana desde o primeiro anno até o sétimo (STEIDEL, 1923, p.16).

Desse modo, Steidel não deixa de legitimar o liceu do qual faz parte. Além de fazer inúmeras referências à Escola Americana, nome que não foi sequer mencionado pelo orador anterior, Steidel cria um paralelismo entre a Escola 
Americana e o Mackenzie College - nunca traduzido por Colégio Mackenzie marcados pelo pioneirismo e pela tradição de ensino:

Pensae [que] a Escola Americana e o Mackenzie College representam um trabalho ininterrupto, em prol da instrução durante 53 annos; que esse trabalho se vae avolumando de anno a anno, pelos seus aperfeiçoamentos, pela sua elevação, pelo numero de seus alumnos, e pelo augmento do corpo docente, e que hoje esta academia é um modelo no seu gênero [...]

...esse programma apresentado como uma aspiração a ser realisada pelo lyceu franco-brasileiro, já é uma realisação pratica levada a effeito pela Escola Americana e pelo Mackenzie College há muitos annos, e com resultados satisfactorios (STEIDEL, 1923, p.15).

O crescimento do número de alunos e de professores, e a verticalização do ensino com suas especializações são elementos que subsumem a academia, uma ressignificação tanto da Escola Americana quanto do Mackenzie College, separados pelo nível de ensino. Este último é usado para marcar a introdução do ensino de nível superior e a sua filiação à universidade americana:

Eis ahi claro o pensamento dominante, o traço de união que nos approxima da França pelo Lyceu S. Paulo; que nos liga aos estados unidos da America do Norte pelo Mackenzie College [...]: cooperação e collaboração. [...]

...o Mackenzie College formando engenheiros brasileiros capazes de planejar e executar os grandes emprenhendimentos [...] fornecerá meios de equilibrar a influencia estrangeira (STEIDEL, 1923, p.19).

A integração das duas entidades - Escola Americana e Mackenzie College em uma academia é ressignificada como instituto instrucional fornecedor de elementos para a administração do governo estadual. Apesar de estrangeiras no nome, estão a serviço do governo paulista:

Seria curioso saber a quantos brasileiros este instituto tem dado instrucção, e quantos de nossos homens, uteis á administração e ao progresso do Estado de São Paulo aqui fizeram seus primeiros estudos. (STEIDEL, 1923, p.19)

Mas não se trata de um instituto de instrução qualquer e sim de um complexo educacional que agrega diferentes cursos em prédios que se edificam com o 
propósito de integralizar a formação do alunado, dando origem a um estabelecimento de complexidade organizacional, em cuja casa os alunos rendem culto a Deus:

Quando contemplamos e admiramos a grandiosidade e a complexidade da organisação actual deste estabelecimento, não devemos esquecer a somma enorme das difficuldades que foram vencidas $[\ldots]$

No regulamento interno desta casa eu encontro uma disposição onde há referencia á questão religiosa, e é aquella em que se estabelece que diariamente os alumnos do curso gymnasial superior reúnem-se no salão nobre do edifício Lane para ouvir a leitura das Escripturas e render culto a Deus. (STEIDEL, 1923, p.10)

O orador defende o "empreendimento" de duas "ideias" que se lhe poderiam associar: a primeira delas diz respeito à religião e a segunda ao reconhecimento do ensino pela instituição novaiorquina. Na sua visão, as práticas religiosas da leitura das "Escripturas" são provas de que a instituição não se pauta no ateísmo, mas também não configuram propaganda religiosa, que parecia se aplicar à atmosfera em torno das atividades mackenzistas relacionadas à religião.

Desconstruído o argumento de que a propaganda religiosa alicerça o empreendimento, Steidel ataca o rótulo "órgão de imperialismo" associado ao Mackenzie College anexado ou filiado à universidade americana. A larga presença de professores estadunidenses e a cooperação e colaboração da Universidade de Nova lorque, com equiparação dos diplomas, parecem estar entre as motivações à crítica ao Mackenzie College, visto, à época, como base do imperialismo americano. Pela sua ótica, o imperialismo americano não estava na motivação do empreendimento, pois a instrução é libertadora:

...eu considero a diffusão da instrucção como um meio de evitar e impedir o imperialismo de uma nação, e não como instrumento de expansão.

$[\ldots]$

....pela instrução é que poderemos nos revoltar contra qualquer Idea de sujeição ou dominação sobre a nossa pátria. (Steidel, 1923, p.1011)

Seguindo as palavras de Vergueiro Steidel, ao contrário do que se propagandeava, o Mackenzie College oferecia instrução como arsenal de defesa 
contra o imperialismo das nações. Desse modo, a sua regência por estrangeiros não deveria ser um entrave às suas atividades, antes, deveria ser encarada como uma forma de expurgação de regionalismos e, portanto, de projeção da sociedade por meio da "divulgação da sciencia".

A defesa do Mackenzie elaborada pelo paraninfo se pauta em quatro argumentos: i. o reconhecimento dos estudos feitos por uma universidade estrangeira acionado pelo Mackenzie College passou a ser projetado por outras entidades de instrução, como o Lyceu franco-brasileiro; ii. o número de professores estrangeiros não supera o de brasileiros; iii. o programa de ensino primário e secundário tem a língua, a geografia e a história brasileira como disciplinas nucleares; iv. a escola introduziu os cantos patrióticos e o hasteamento da bandeira brasileira. Ao desenvolver esses quatro argumentos, o orador atualiza a Escola Americana no quadro de referência:

...esse programma [reconhecimento do ensino] apresentado como uma aspiração a ser realisada pelo lyceu franco-brasileiro, já é uma realisação pratica levada a effeito pela Escola Americana e pelo Mackenzie College há muitos annos, e com resultados satisfactorios $[\ldots]$

Os professores estrangeiros collaboram com os professores brasileiros, e no corpo docente da Escola Americana a maioria de professores é formada por senhoras brasileiras, da mesma forma que no corpo docente do Mackenzie College, eu encontro nada menos que 16 nomes brasileiros, par aum total de 22 professores [...]

O curso de instrucção primaria e secundaria da Escola Americana desde o primeiro anno até o sétimo, dá importância capital ao estudo da nossa língua materna, da geographia do Brasil e da história patria, feito em livros brasileiros dos nossos melhores escriptores, e em língua nacional $[\ldots]$

Solemnidade de liturgia patriótica, que a Escola Americana foi a primeira a introduzir em nossas escolas. (Steidel, 1923, p.16)

Ao fazer ecoar o nome Escola Americana - e Mackenzie College relacionando-o à instrução de elementos nacionais e ao patriotismo brasileiro, o orador o transformava em mero rótulo, dissociando-o de projetos imperialistas americanos, tomando como ilustração o caso do Lyceu Franco-Brasileiro, reiteradamente recuperado ao longo do discurso, para franquear as atividades mackenzistas. Entretanto, a doação da terça parte da fortuna de John Mackenzie 
para a criação da Escola de Engenharia e ampliação das instalações da escola bem como a adoção de seu nome para os cursos superiores foi mais uma munição para a tese de imperialismo americano, que o orador desmonta a partir da ideia de que a formação de "engenheiros brasileiros capazes de planejar e executar os grandes emprehendimentos industriaes de que necessita o Brasil" deve ser lido como "resistência, á expansão econômica que se desenha no futuro" e que o Mackenzie College, nesse sentido, vinha proporcionar o "estabelecimento do equilíbrio entre duas forças opostas".

Os discursos dos dois paraninfos são praticamente opostos no que diz respeito ao quadro de referenciação: enquanto Arrojado Lisboa se restringe ao uso de elementos nominais comuns, como "escola", "instituição", "instituto", "estabelecimento", exclui o nome "Escola Americana" de suas reflexões e adota o nome português "Collegio Mackenzie", Vergueiro Steidel abre o peito e evoca o primeiro nome não menos do que nove vezes e o segundo, cinco. A inibição e o escancaramento que diferenciam os dois quadros são reveladoras das tensões e da atmosfera opressora que se desenvolveu, no entresséculos, em torno de atividades de entidades estrangeiras de que o Mackenzie é um dos personagens. É provável que, no incômodo causado pela ausência de uma identidade coletiva (CARVALHO, 1990, p.67), o timbre do estrangeiro, ao mesmo tempo que dava o tom do cosmopolitismo do período marcado pela forte presença de imigrantes na cidade de São Paulo, era um ruído que precisava ser eliminado para abrir o caminho da forja da identidade paulistana.

\subsection{As teias de referenciação: o ETHOS MACKENZISTA}

A manipulação simbólica na construção do imaginário mackenzista se faz de dentro para fora, pelas palavras do diretor Horace Lane, e de fora para dentro, pelos discursos proferidos por ocasião de colação de grau dos estudantes. Como uma estratégia defensiva contra os ataques nacionalistas do período, que criticavam a atuação de protestantes americanos, e como resultado de suas colaborações consultivas no âmbito da política educacional do estado, o diretor, ao apagar o modificador "americano", por pressão dos nacionalistas, destaca a expressão "Escola" criando o efeito não proposital de formar no imaginário coletivo a ideia de 
que as instituições escolares [estaduais] fossem partes ou especializações da Escola, efeito ampliado pela localização da Escola Americana - a um passo da Escola Normal na Praça da República e entre esta e o Ginásio da Capital, alocada no prédio da pinacoteca (RIBEIRO, 2015, p.69).

Os quadros referenciais dos discursos dos paraninfos também captam as tensões nacionalistas. Enquanto o orador Arrojado Lisboa omite o nome da escola e usa o termo aportuguesado "Collegio Mackenzie", opacizando o americanismo, o orador Vergueiro Steidel faz ecoar os nomes Escola Americana e Mackenzie College inúmeras vezes, vinculando-os a um repertório de tradição e pioneirismo, que tem o Lyceu Franco-Brasileiro como exemplo licenciado e legitimado. Nos dois textos, 0 termo "instituto" é correlato de escolas especializadas ao passo que o termo "instituição" aparece como sinônimo de "estabelecimento" com organização complexa, a qual, se torna "Escola" / College a partir da associação com os valores culturais americanos, por meio do reconhecimento da universidade de Nova lorque. Independentemente de participação dos poderes públicos, tal "Escola" se projeta como um ambiente familiar que por ter regulamentos de base religiosa e estar vinculada ao animus ganha o estatuto de "casa". 


\section{CAPÍTULO IV - COLOCAÇÃO PRONOMINAL PAULISTANA: O CASO DA COMUNIDADE MACKENZIE}

\subsection{A língua portuguesa nos primórdios da Escola Americana}

No início da década de 1870, a presença cada vez maior de missões religiosas protestantes no Brasil fez com que, em seus trabalhos, os missionários estrangeiros se deparassem com a questão do multilinguismo. No estado de São Paulo, os cultos presbiterianos eram proferidos em línguas como o inglês e o alemão para colonos provenientes de países como a Inglaterra, Estados Unidos e Alemanha. O primeiro serviço religioso desse tipo de que se tem notícia em São Paulo, em língua portuguesa, se deu na cidade de Rio Claro, no dia 29 de novembro de 1863 (RIBEIRO, 1973, p.141-142).

O principal instrumento dos missionários presbiterianos era a palavra. Fosse ela falada ou escrita. Era preciso, pois, definir quais idiomas seriam priorizados em cultos e reuniões religiosas e, o mais importante, qual seria o lugar da língua portuguesa nesses trabalhos.

O exemplo do missionário presbiteriano George Whitehill Chamberlain estadunidense e cofundador ${ }^{85}$ da Escola Americana - refletia a problemática das línguas em suas pregações:

Afóra o tempo occupado nas viagens indicadas e outras que tinha de fazer a esta Corte nos mezes de Janeiro e Abril tenho permanecido na cidade de S. Paulo mantendo culto público aos Domingos 2 vezes em Portuguez e uma vez em Inglez [...] (RELATÓRIO, 1871, p.18)

Sua preocupação com a vulgarização da língua portuguesa era considerável, sobretudo, num ambiente cosmopolita como a cidade de São Paulo onde, na segunda metade do século XIX, já havia grande número de imigrantes estrangeiros provenientes de países como Itália, Espanha, Portugal, Alemanha e outros (BACELLAR, 2006; BASSANEZI, SCOTT et al, 2008, p.19).

\footnotetext{
${ }^{85}$ A esposa de George Chamberlain, Mary Dascomb, foi a primeira professora daquilo o que viria a se transformar na Escola Americana. Portanto, não há sentido nenhum em não considerá-la, junto a seu marido, cofundadora dessa escola (N. do A.).
} 
Em ambientes de culto religioso - frequentados predominantemente por imigrantes compatriotas, como era o caso dos confederados estadunidenses de Americana e Santa Bárbara D'oeste - a postura linguística do religioso era diferente daquela adotada na praça pública, onde raças, etnias e línguas diversificadas circulavam:

Logo em seguida á ultima reunião do Presbyterio dirigi-me ao interior pregando em Inglez entre os colonos que existem na visinhança de Santa Barbara e em Portuguez nessa praça onde houve grande concorrencia durante varias noites [...] (RELATÓRIO, 1871, p.28)

Outro momento interessante é aquele em que o pastor presbiteriano relata a primeira proferição de um culto evangélico em língua portuguesa numa determinada localidade: "Dirigimo-nos a capella nova de Patrocinio e ahi pela primeira vez celebramos culto Evangelico na lingua do paiz" (RELATÓRIO, 1871, p.35). Fazendonos inferir que o culto em língua nacional era um avanço em relação aos cultos em línguas estrangeiras comuns nas colônias de imigrantes, e, mais do que isso: o fato de se celebrar um culto em língua portuguesa representava avanço no processo de evangelização presbiteriana no Brasil, visto a dificuldade de conversão e proselitismo para o protestantismo de um povo aculturado pela religião católica dominante e hegemônica no país. Ademais, a população brasileira rural, nesse período, era praticamente analfabeta, o que desfavorecia a adesão aos protestantes que se baseavam, principalmente, na leitura da Bíblia para converterem seus fiéis (MENDONÇA, 2008, p.179-185).

Ao fundarem o Mackenzie como escola que se presumia moderna e inovadora, os presbiterianos estadunidenses poderiam ter imposto a língua inglesa como língua oficial de ensino. No entanto, não foi isso o que aconteceu:

[...] E a língua inglesa crescia em importância, igualando-se à francesa no campo cultural, superando-a, até, no campo comercial. Por que, então, não se deveria empregar a língua inglesa oficialmente na Escola Americana? A ideia cresceu, tomou vulto e empolgou a assembleia. Só a muito custo Chamberlain conseguiu demover a tendência dos presentes, argumentando que o uso da língua portuguesa foi estabelecido como princípio fundamental desde a hora em que a primeira menina chegou à residência da sra. Chamberlain. (GARCEZ, 2004, p.57) 
Esse ponto é muito importante e chama a atenção por uma série de razões. Em primeiro lugar, por que a opção de uma escola estadunidense, como era o Mackenzie, pelo português como língua oficial de ensino? Além do que, não era a tônica das instituições de ensino brasileiras da época ensinar língua portuguesa. As escolas preferiam ensinar francês, italiano, alemão etc. relegando, desse modo, o português ao uso familiar e doméstico, sendo que mesmo neste ambiente as elites adotavam o francês em alguns casos (BINZER, 1994, p.67).

Outro fator interessante é um certo desprezo explicitado pelos presbiterianos estadunidenses, em alguns escritos, ao que dizia respeito a instituições oriundas da cultura portuguesa. A religião católica figurava como um empecilho aos protestantes, até pelo fato de ter sido a religião oficial do estado brasileiro por todo o período imperial. Em seguida, o modelo de governo monárquico que, muito embora tenha sido superado pela proclamação da república, em 1889, ainda "reinava" subrepticiamente em boa parte das práticas políticas e diplomáticas brasileiras. Por fim, e não menos importante, foi o fato de que, assim como o império monárquico, a escravidão havia acabado de ser proibida legalmente em 1888, o que num período de tempo de 30 anos - pensando que o recorte temporal deste trabalho se estende aproximadamente entre 1890 e 1920 - mantém aberta a ferida da condição indigna e desumana dos negros africanos e de seus descendentes naquele momento histórico:

Sabe-se que o Brasil foi colônia de Portugal por muitos anos. $O$ pequeno e pobre Portugal saiu da corrida das nações há duzentos anos - o Brasil permaneceu dentro, mas muito prejudicado pela monarquia, escravidão, e por um estado religioso. Hoje, ele se libertou dos seus três pesos mortos e demanda um novo lugar entre as nações livres. [...] Mas mesmo com todas as suas fraquezas e vícios, e apesar de sofrer uma influência espiritual ruim por gerações, os brasileiros são uma raça generosa e hospitaleira, muito melhores que seus ancestrais portugueses. ${ }^{86}$ (MACKENZIE COLLEGE, 1909, p.19 - Grifos nossos)

O legado português ao Brasil funcionou como um obstáculo à implementação do protestantismo estadunidense de um modo geral, exceto no que se refere à

\footnotetext{
86 Tradução livre de: "It is well known that Brazil was for many years a colony of Portugal. Poor little Portugal dropped out of the race of nations two hundred years ago - Brazil remained in, but heavily handcapped by monarchy, slavery and a state church. To-day she has thrown off her three dead weights, and demands a new place among free nations. [...] But with all their weaknesses and vices, and in spite of bad spiritual guindance for generations, the brazilians are a generous, warm-hearted race, far better than their portuguese ancestors."
} 
língua portuguesa. A escolha de qual língua deveria ser adotada oficialmente na impressão de material de ensino e nos cursos ministrados, em sua maioria, por professores estrangeiros é, portanto, um dos pontos chave do programa da escola:

O Estabelecimento toma em especial consideração o estudo theorico e pratico da lingua nacional, a que dará todo o possivel desenvolvimento. (PROGRAMMA DO CURSO SUPERIOR DA ESCHOLA AMERICANA, 1894, p.08)

Houve alguns protestos por parte de famílias e de pais de alunos que, talvez, desejassem que o curso fosse ministrado em francês, devido ao prestígio dado a esse idioma pelas elites do período ${ }^{87}$. Sabemos que, no auge da Belle Époque paulistana, as famílias oligárquicas não se interessavam muito pelo aprendizado consciente e metódico da língua portuguesa. Muitos pais contratavam preceptoras estrangeiras com a intenção de tornar seus filhos bilíngues ou poliglotas, sempre privilegiando línguas estrangeiras como o francês, inglês, italiano ou alemão, almejando se colocar no mesmo patamar dos países civilizados, já que falavam e liam notícias em português, língua aprendida espontaneamente em casa, como se observa nos relatos memorialísticos de Maria Paes de Barros:

As lições ministradas por Mademoiselle eram todas em francês e alemão. Dindinha, dotada de excelente ouvido musical, ensinava piano e português. Pobre vernáculo! Enquanto a gramática francesa era decorada a fundo, limitava-se $\mathrm{o}$ ensino do português a minguados estudos no pequeno volume da Enciclopédia. (BARROS, 1998, p.14)

Apesar desses impasses envolvendo a cultura e língua portuguesas, George Chamberlain optou pela língua portuguesa tanto como veículo de comunicação quanto como instrumento de ensino-aprendizado em sua recém constituída escola:

A língua na qual a instruç̧ão devia ser ministrada [...] Devia ser, salvo no caso particular do estudo de línguas estrangeiras, a língua portuguesa. Tal não foi a esperança de muitas famílias, facto que causou o cancellamento de nove dos primeiros doze matriculados. Apesar disto, a resolução foi mantida e assim foi possível responder, muitos annos depois, á circular do Departamento de Instrucção

87 "Era comum no Brasil o emprego da língua francesa na instrução escolar, principalmente nos colégios religiosos, pois o francês era o idioma das elites. A poderosa França estendia sua influência em todos os ramos da atividade humana. A língua francesa oferecia, por isso, um fascínio irresistível" (GARCEZ, 2004, p.57) 
Pública do Estado de São Paulo (estabelecendo o emprego da língua portuguêsa como vehiculo de ensino) que, desde a sua fundação, havia cerca de cincoenta annos, tal tinha sido o costume da escola. (STEWART, 1932, p.17)

Os protestantes do Mackenzie não impuseram o inglês como língua oficial em sua escola e não hesitaram em tecer elogios à língua portuguesa que encontraram no Brasil, com a intenção de usá-la para implementarem o complexo educacional de orientação estadunidense e presbiteriana e parte de sua influência cultural em São Paulo:

A língua do país é o português - uma língua irmã do espanhol, mas claramente, uma língua distinta. Trata-se de uma bela língua, apropriadamente chamada de "a filha mais velha" do latim. Ela é compacta, expressiva, flexível e bem adaptada à oratória e à literatura ${ }^{88}$

O conceito de língua oficial, como era compreendido pelos mackenzistas, estava atrelado à ideia de institucionalização através da lei. Desse modo, somente instituições reconhecidas pela lei seriam capazes de oficializar o uso de uma língua. Para isso, de acordo com Bourdieu (2008), é necessário que seja mobilizada uma rede de difusores autorizados para tal. O primeiro é aquele relacionado à codificação linguística, ou seja, os gramáticos com suas gramáticas normativas, filólogos e estudiosos da linguagem. 89 O segundo componente difusor - talvez o mais importante - é a figura do professor responsável pela decodificação e implementação do código linguístico oficial numa dada comunidade linguística. Finalmente, é possível afirmar que cada integrante dessa comunidade linguística é, também, um agente responsável por implementar e, mais que isso, legitimar esse código entre seus pares por meio de avaliações sobre a língua em situações de uso

\footnotetext{
88 Tradução livre de: "The language of the country is the Portuguese - a sister language to the Spanish, but clearly a distinct language. It is a beautiful language, and has been appropriately styled the eldest daughter of Latin. It is compact, expressive, flexible, and well adapted for oratory and literature." (LANE, 1890, p.19).

${ }^{89}$ Vale ressaltar que ao menos quatro dos grandes gramáticos brasileiros da virada do século XIX para o XX estavam ligados ao Mackenzie diretamente: Júlio Ribeiro, Eduardo Carlos Pereira e Santos Saraiva, que foram professores dessa escola no início de sua atividade; e indiretamente, como é o caso de João Ribeiro, que teve sua gramática adotada pelo Mackenzie por vários anos. (mais informações sobre os gramáticos do Mackenzie em 4.2.2).
} 
específicas capazes de proporcionar um alto grau de coesão normativa em torno da língua numa comunidade inteira.

A esse respeito, Bourdieu fala sobre a constituição das comunidades linguísticas através da coesão proporcionada pelo uso da língua oficial. Coesão verificável entre aqueles que já possuem capital simbólico elevado, ao qual a língua oficial só é confirmada como mais um bem simbólico entre outros - por meio do acesso mais facilitado a livros, escolas e instituições que zelam pela manutenção e reprodução desse bem cultural. Essa elite letrada, detentora da norma linguística que será difundida em sua comunidade, o faz verticalmente, sempre regulando seu acesso por meio de aprovações e reprovações baseadas em críticas e juízos de valores. A partir dessa regulação, cria-se um verdadeiro mercado de bens linguísticos ao qual se poderia muito bem aplicar a máxima bíblica e calvinista "Muitos são chamados, mas poucos escolhidos" como metáfora esclarecedora para definir aqueles que conseguem ter acesso à língua oficial:

Produzida por autores com autoridade para escrever, fixada e codificada pelos gramáticos e professores também incumbidos de inculcar seu manejo [...] a língua oficial está enredada com o Estado, tanto em sua gênese como em seus usos sociais. É no processo de constituição do Estado que se criam as condições da constituição de um mercado linguístico unificado e dominado pela língua oficial: obrigatória em ocasiões e espaços oficiais (escolas, entidades públicas, instituições políticas etc.), esta língua de Estado torna-se a norma teórica pela qual todas as práticas linguísticas são objetivamente medidas. Ninguém pode ignorar a lei linguística que dispõe de seu corpo de juristas (os gramáticos), e de seus agentes de imposição e de controle (os professores), investidos do poder de submeter universalmente ao exame e à sanção jurídica do título escolar o desempenho linguístico dos sujeitos falantes. (BOURDIEU, 2008, p.32 - Grifo do autor)

Paralelamente à inovação de seus métodos de ensino e de sua concepção de mundo, o Mackenzie tentou inovar na escolha da língua a ser usada dentro das aulas de diferentes disciplinas e fora delas. Atentos à força da imprensa e movidos pelo interesse em ampliar o rol de adesionistas, provavelmente, eles lançaram mão desse feito como estratégia para se aproximar da nova burguesia que ascendia em São Paulo, construindo, com isso, sua aceitação por parte de algumas das principais esferas políticas e sociais com as quais tinham interesse de "negociar". O uso de uma nova estratégia linguística pode, também, ter levado o Mackenzie a instaurar 
suas bases simbólicas sempre de olho no futuro e no progresso desenvolvimentista, dois de seus principais leitmotivs.

Por meio da investida do ensino do português como língua oficial, os mentores do Mackenzie intuíam ganhar o apoio de uma elite republicana cujo ímpeto nacionalista se tornava cada vez mais arrebatador. Elite esta que se deixava influenciar - no entresséculos - pela ascendência de um forte sentimento nacionalista já observável em escala mundial. ${ }^{90}$ Por isso o uso do termo "língua nacional91" - e não "língua portuguesa" - pode ser interpretado como uma estratégia de aproximação do Mackenzie a um Brasil emergente cuja incipiente burguesia nacionalista almejava seu desenvolvimento social, político e econômico internamente. Era o início de um novo ciclo no qual as novidades nos campos político e científico demandavam a fixação de uma língua inovadora que fosse capaz de descaracterizar o conceito de nação estabelecido até então pela oligarquia brasileira ligada ao mundo rural.

Uma das principais questões deste trabalho é saber como funcionava, em termos específicos, a língua oficial da qual a comunidade Mackenzie se apropriou ao se instalar no Brasil e com a qual visava preparar as gerações futuras da elite paulistana.

Qual gramática ou padrão gramatical do português era utilizado por eles?

É pouco provável que os presbiterianos do Mackenzie tenham optado por usar o Português Europeu (PE), visto que a cultura portuguesa lastreada nos preceitos católicos era um obstáculo aos avanços protestantes. Se considerarmos a

\footnotetext{
90 "A crescente significação da 'questão nacional' nos quarenta anos que precederam 1914 não é medida simplesmente por sua intensificação nos velhos impérios multinacionais austrohúngaro e turco. Havia se tornado uma questão importante da política interna de quase todos os Estados europeus. [...] Os EUA e a Austrália são exemplos evidentes de Estados-nações nos quais todas as características nacionais específicas e critérios de existência de nação foram estabelecidos desde o final do século XVIII" (HOBSBAWM, 1990, p.128)

91 O último quartel do século XIX é marcado pela discussão sobre a denominação do português falado no Brasil. A insistência de filólogos portugueses em rotular essa variedade linguística como "dialeto brasileiro" e a apresentar os seus traços como vícios de linguagem, em época de forte antilusitanismo, provocou antagonismo da parte de brasileiros que entendiam o termo dialeto como forma inferior de língua. Após alguns impasses, tanto os filólogos portugueses quanto os brasileiros passaram a usar "língua nacional", cada um "puxando a sardinha para a sua brasa", naturalmente. (Charlotte Galvez e Marilza de Oliveira, no prelo)
} 
relação entre língua e cultura, não é de se estranhar o afastamento da matriz europeia da língua portuguesa. Similarmente, embora por outros motivos, também é pouco provável que os presbiterianos do Mackenzie tenham optado pelo Português Vernacular Brasileiro (PVB) - que fora enfatizado sobremaneira pela literatura modernista e que é considerado por alguns estudiosos a variedade linguística genuinamente brasileira - por se tratar da "língua solta do povo"; das classes "inferiores" com as quais a comunidade Mackenzie não se identificava.

Restam as possibilidades de que a comunidade Mackenzie tenha se identificado com o Português da Elite Paulista Republicana (PEPR), visto que aquela comungava dos ideais políticos do grupo usuário dessa norma e, finalmente, com o Português Literário Brasileiro (PLB), visto ser usado por escritores de literatura que apoiavam e problematizavam a questão da língua nacional, ao mesmo tempo em que se mantinham ao lado de uma elite modernizadora e, simultaneamente, conservadora. ${ }^{92}$

A questão central é, pois, além de definir as diferentes gramáticas do português reconhecidas na Belle époque paulistana, descobrir que variedade de português culto era usada no Mackenzie.

\subsection{A Colocação pronominal em orações infinitivas preposicionadas}

Para descobrir qual era a língua portuguesa usada no Mackenzie, traçaremos um perfil da colocação pronominal em orações infinitivas preposicionadas doravante OIP's - no período da Primeira República, que servirá de embasamento para a análise desse mesmo tipo de colocação pronominal em textos produzidos pela comunidade Mackenzie.

\footnotetext{
92 "No entresséculos estudado neste trabalho, a literatura brasileira caracterizou-se predominantemente pelo sincretismo estético e pelo entrecruzamento de várias correntes artístico-literárias. Nesse período, alguns autores mostravam certo inconformismo perante aspectos políticos e sociais, incorporando conceitos próprios que abririam o caminho para o movimento modernista de 1922. Em contrapartida, muitas obras ainda mostravam influência das escolas literárias do passado como o Realismo, o Naturalismo, o Parnasianismo e o Simbolismo. A essas tendências, cuja dicotomia era renovadora e conservadora, chamou-se de Pré-modernismo" (BURKARD, 2014, p.59-60).
} 
A partir dos pressupostos teórico-metodológicos da teoria variacionista laboviana, serão levantados alguns grupos de fatores linguísticos e extralinguísticos com a finalidade de observar o condicionamento da colocação pronominal em OIP's na amostra mackenzista. Em seguida, serão apresentados os resultados da análise da referida amostra, procurando identificar o padrão linguístico que teria servido de modelo para a comunidade presbiteriana Mackenzie que se instalou na cidade de São Paulo no final do século XIX.

Dentre os padrões linguísticos de colocação pronominal em OIP's analisados, destacam-se quatro, a saber:

1) Aquele que condiz com o $P E$, ou seja, uso categórico de ênclise com a preposição a e uso categórico de próclise com as demais preposições (OLIVEIRA, 2011);

2) Aquele condizente com o PVB que significa, grosso modo, o uso generalizado da próclise (CYRINO, 1993);

3) Aquele condizente com o PEPR, que se refere ao uso generalizado da ênclise (SANTOS SILVA, 2012; OLIVEIRA, 2013);

4) Aquele condizente com o PLB, que prevê o uso elevado de ênclise, mas com margem de variação (SCHEI, 2002; OLIVEIRA, 2013).

\subsubsection{A ênclise como símbolo de prestígio}

A colocação pronominal sempre foi uma questão sociolinguística central na construção da norma culta escrita brasileira. A partir de meados do século XIX, houve um grande movimento no sentido de legitimar e difundir o modelo europeu de colocação pronominal no Brasil. Por conseguinte, a norma lusitana, essencialmente enclítica, passou a obter bastante prestígio entre acadêmicos e intelectuais brasileiros. Um exemplo disso é a Constituição da república dos Estados Unidos do Brasil, promulgada em 1891. Como observa Pagotto (1998), esse texto se opõe, radicalmente, à Constituição política do império do Brasil, de 1824, por ser predominantemente enclítico no que concerne à colocação pronominal, ao passo 
que a constituição imperial é predominantemente proclítica, o que refletiria ainda o português europeu clássico instaurado no Brasil no século XVI.

As questões que colocamos e que se relacionam diretamente com a colocação de clíticos pronominais em orações infinitivas preposicionadas, portanto, dizem respeito aos seguintes temas relevantes quando se discute a colocação pronominal brasileira no período estudado:

i. O que levou a norma brasileira de colocação dos clíticos pronominais a se tornar enclítica no final do século XIX?

ii. Por que a ênclise se tornou marca de prestígio entre os letrados?

iii. Qual era o estatuto da próclise na escrita brasileira?

Como dissemos, o português europeu moderno passou por profundas transformações no século XIX, se consolidando como uma língua essencialmente enclítica (MARTINS, 1994, p.67). Na leitura de Pagotto (1998), essa norma teria sido importada e imposta ao Brasil, criando uma situação dicotômica entre a língua escrita - europeia e enclítica - e o vernáculo falado - brasileiro e proclítico. Mais que uma dicotomia, essa divisão entre escrita e fala configuraria uma verdadeira diglossia que segregava a pequena elite alfabetizada das massas populares analfabetas.

De acordo com essa leitura, um fator preponderante teria levado a classe dirigente brasileira a usar a norma escrita do português europeu: o processo de europeização da Belle Époque (SEVCENKO, 2003, p.29-32).

Com o advento da república, várias mudanças de ordem cultural e social foram promovidas pela elite no sentido de consolidar o sistema republicano e "renovar" a sociedade em relação ao antigo regime. Essas reformas se baseavam em modelos culturais europeus, principalmente o francês, e foram realizadas com os excedentes da economia cafeeira que investiu na urbanização e higienização de grandes cidades como São Paulo e Rio de Janeiro. A industrialização no Brasil só começou a impulsionar o mercado interno em meados da década de 1910; até esse momento, a maioria dos bens duráveis, maquinários e artigos de luxo eram importados da Europa e dos Estados Unidos (NAGLE, 2009, p.24-25). Além disso, a 
partir da república, as relações sociais deixaram de ser do tipo senhorial - como eram no império - para se tornarem burguesas, o que pressupunha a estigmatização de toda e qualquer manifestação de brasilidade autóctone relacionada aos períodos colonial e imperial, assim como a criminalização e, no limite, a eliminação daqueles que as propagavam. Daí que, na Belle Époque brasileira, foram evitadas e até mesmo caçadas por força de lei, manifestações artísticas, religiosas e linguísticas provenientes de estratos marginalizados da sociedade compostos em sua maioria por índios, negros e mestiços (SEVCENKO, 2003, p.33).

A seguir, ilustraremos como se deu parte desse processo com o depoimento de um cronista carioca acerca da presença de índios, em meio a embaixadores, no Congresso Pan-Americano realizado no Rio de Janeiro em 1908:

A figura do índio nos perseguia com a tenacidade do remorso. A sua
cara imóvel interpunha-se à dos embaixadores e à nossa. As suas
plumas verdes e amarelas quebraram a uniformidade negra das
casacas. Broncas sílabas tupis pingaram, enodoando o primor
das línguas educadas (JORNAL DO COMMERCIO, "A semana",
30.3.1908 apud SEVCENKO, 2003, p.36 - Grifo nosso).

Reforçando o intenso processo de europeização que caracterizou a transição do império para a república, a presença de imigrantes portugueses também teria contribuído para a implementação, legitimação e difusão da norma escrita do português europeu como norma linguística prestigiada no Brasil. É provável que, entre 1890 e 1920, mais de 800 mil portugueses tenham ingressado no Brasil como imigrantes. Em termos de nacionalidade, os portugueses foram os que mais emigraram da Europa para o Brasil, seguidos dos italianos, espanhóis e alemães. Apesar de a maioria da população ser analfabeta, um bom número de portugueses imigrados eram pessoas cultas perseguidas pela adesão às ideias republicanas e monarquistas, quando da proclamação da república em Portugal (BACELLAR, 2006; ROCHA, 2007).

No caso da colocação pronominal, a próclise era associada tanto ao período pré-republicano - ver o predomínio da próclise na constituição imperial — quanto às classes populares marginalizadas que a utilizavam na fala. Por isso, seu uso era considerado impróprio e desprestigiado se comparado ao uso da ênclise. 


\subsubsection{A colocação pronominal nas OIP's em gramáticas normativo-prescritivas}

Poucos são os gramáticos, filólogos e linguistas que abordaram os clíticos em OIP's na virada do século XIX para o XX. Talvez por se tratar de um ambiente sintático que ora apresenta variação na ordem de colocação do clítico ora se encontra em distribuição complementar. Do ponto de vista da ordem sintática, a posição do clítico nesse constituinte pode variar da seguinte maneira:

- $\mathrm{P}+\mathrm{Cl}+\mathrm{V}^{93}$, em que o clítico ocupa a posição pré-verbal (próclise: "de te falar");

- $\quad \mathrm{P}+\mathrm{V}+\mathrm{Cl}$, em que o clítico ocupa a posição pós-verbal (ênclise: "de falar-te").

Das gramáticas normativas brasileiras do entresséculos poucas apresentam as OIP's como um contexto saliente para o estudo da colocação pronominal. Aquelas que tratam desse ambiente trazem prescrições que deitam raízes na Grammatica Expositiva do presbiteriano Eduardo Carlos Pereira ${ }^{94}$, segundo o qual a ênclise do clítico acusativo de $3^{a}$. pessoa em presença da preposição é motivada pela eufonia:

7. ${ }^{\text {a }} \mathrm{E}$ ' mais commummente enclitico com os infinitivos regidos da preposição a, exs.: "Correu a levar-lhe as boas novas" - "O meu (phantasma) tinha sido a Primavera, e continuava a sel-o" (A. C.) "Talleyrand o aconselhou a crucificar-se" - "Elle resolveu a compral-a ou compral-o".

Nota. - O ultimo exemplo revela a razão porque se generalizou a ênclise com os infinitivos regidos de $a$ : foi a tendencia para evitar o hiato, a que levaria a proclise: "Elle resolveu a a comprar, ou a o comprar" E' anti-euphonico este passo de Vieira “...para que não continuem a o ser". Com as outras preposições é commum a proclise: "Os paes de famílias os depositariam, para se tornarem muitas vezes a reler" (A. C.) - "Estuda-as sem pensar em as dissecar" (C. A) - "Desejoso de me empregar nelle." (A. V.) (PEREIRA, 1907, p.244).

93 Entendemos por clítico o pronome átono. $\mathrm{P}$ corresponde à preposição, $\mathrm{Cl}$, ao clítico pronominal e V, ao verbo.

94 Eduardo Carlos Pereira foi professor de língua portuguesa da Escola Americana de 1878 a 1894 (GARCEZ, 2004; GUTIERREZ, 2010) e articulador do projeto de nacionalização da Igreja Presbiteriana, tendo-se tornado o primeiro pastor nacional da Igreja Presbiteriana de São Paulo. (Ver a polêmica envolvendo Eduardo Carlos Pereira e Horace Lane no capítulo 2 deste trabalho, em Gutierrez (2010) e também em Gomes (2001)). 
Na mesma linha de raciocínio, Sousa da Silveira95 apresenta a eufonia como motivação da ênclise no contexto da preposição a:

\begin{abstract}
A ênclise é de praxe:
Nos infinitivos regidos da preposição $a$, quando o pronome átono tem a forma $O(l o)$. [...] Vimos que com o infinito regido de preposição tanto ocorre a próclise como a ênclise. No próprio caso de que estamos tratando aparecem na língua antiga exemplos de próclise [...] A seleção em favor da ênclise parece devida a eufonia. (SILVEIRA, 1983, p.255-256)
\end{abstract}

O ambiente sintático da preposição a seguida dos diferentes clíticos, sem estar restrita aos clíticos acusativos de 3a․ pessoa, também é apontado como favorecedor da ênclise por Said Ali96:

A particula $a$, regendo o infinitivo e precedendo-o imediatamente, não desloca, no falar hodierno, nem os pronomes $0, a$, os, as, nem os demais pronomes atonos. (SAID ALI, 1927, p.280-282)

Diferentemente daqueles que viriam a ser seus sucessores, Julio Ribeiro ${ }^{97}$ preceituara a variação na colocação dos clíticos em OIP's sem atentar para a questão da eufonia. Todavia, esse autor apenas fizera uma breve menção acerca desse tipo de colocação pronominal, se concentrando, assinala Oliveira (2011), numa análise com viés mais morfológico e menos sintático da colocação pronominal:

8) Com o verbo no infinito pessoal, estando o sujeito occulto, é indifferente antepôr ou pospôr o pronome objecto, ex.: "Sem o ter ou Sem tel-o".

\footnotetext{
95 Sousa da Silveira, concursado como docente de Português na Escola Normal do Distrito Federal (Colégio D. Pedro II), publicou As Lições de Português em artigos na Revista de Língua Portuguesa, entre 1921 e 1923.

${ }^{96}$ Foi professor de alemão na Escola Militar e do Colégio Pedro II. Lecionou também francês, inglês e geografia. Destacou-se nos estudos linguísticos, inovando o campo ao discutir questões sintáticas e, no âmbito da história da língua portuguesa, dar importância ao período clássico e não medieval da língua (MARTINS, 1996).

97 De forma análoga ao que aconteceu com Eduardo Carlos Pereira, Júlio Ribeiro figura entre os primeiros professores brasileiros da Escola Americana de São Paulo, no momento mesmo de sua fundação, em 1870, por George Chamberlaim. Segundo Lessa (1938), Júlio Ribeiro foi recebido por profissão de fé e batismo pelo Reverendo Chamberlain em 17 de abril de 1870, em São Paulo. Além de presbiteriano, era maçônico, seguidor do Evolucionismo de Darwin e do Positivismo de Comte. Em 1881, lança sua Grammatica Portugueza que, segundo Vidal Neto (2010), foi "a primeira gramática brasileira fundamentada no histórico-comparativismo, método de estudo gramatical que analisa e prova empiricamente os fenômenos linguísticos, isto é, uma gramática científica. Segundo os prospectos do Mackenzie College, esta gramática foi utilizada na Escola Americana de 1904 a 1914, aproximadamente.
} 
9) Com dous verbos no infinito, colloca-se o pronome objecto ou antes do primeiro, ou depois do segundo, ou entre ambos, ex.: "Sem nos poder vêr, ou Sem poder vêr-nos, ou Sem poder-nos vêr" (RIBEIRO, 1881, p.254).

Excentuando-se Said Ali (1927), esses apanhados nas gramáticas da Primeira República indiciam que, lá onde ocorre, a prescrição pela ênclise pronominal no ambiente de OIP's é adstrita ao contexto da preposição a seguida de clítico acusativo de 3a. pessoa (o/a). Entretanto, essas regras parecem se constituir a partir do século XX, visto que a gramática de Júlio Ribeiro, de 1881, não apresenta esse tipo de restrição nem a gramática de João Ribeiro (1900)98, que sequer faz menção a esse ambiente sintático. Esses preceitos que, à primeira vista, parecem estar em consonância com a gramática do português europeu, entretanto, apresentam algumas particularidades linguísticas que não confirmam esse alinhamento, como se verá adiante. Há que se ressaltar que a gramática de João Ribeiro foi adotada pelo Mackenzie entre 1893 e 1904 e substituída pela gramática de Júlio Ribeiro, entre 1904 e 1914 (PROSPECTO, 1909). Como nenhuma das duas gramáticas faz prescrições sobre a colocação pronominal no contexto das orações infinitivas preposicionadas, podemos supor hipoteticamente que os textos produzidos na comunidade Mackenzie adotem a variação linguística em OIP's, como veremos adiante.

${ }^{98}$ A primeira edição da Grammatica Portugueza, de João Ribeiro, data de 1887. Assim como a de Júlio Ribeiro, a gramática de João Ribeiro também seguia o método histórico-comparativo. Segundo os prospectos do Mackenzie College, esta gramática foi utilizada no Mackenzie de 1893 a 1904, nos cursos de nível superior. Sobre a postura de João Ribeiro acerca do problema da colocação pronominal: "[...] sua luta mais constante, travada desde seus começos como escritor e estudioso da linguagem, foi contra as regras de colocação dos pronomes, que escravizam o escritor brasileiro a normas vigentes na época em Portugal, e que não encontravam apoio sequer na linguagem portuguesa mais antiga. [...] apresentando um estudo histórico sobre o assunto, [João Ribeiro] afirma: 'Ora, é no século XV que, em Portugal se notou o fenômeno tão acremente censurado no Brasil a anteposição nas orações principais dos pronomes oblíquos. Basta-nos citar a Crônica do Condestável onde noventa e nove por cem vêzes é observada a sintaxe dita brasileira'. [...] 'A nossa gramática não pode ser inteiramente a mesma dos portuguêses. As diferenciações reclamam estilo e métodos diversos'" (SCHNAIDERMAN, 1971, p.65-93). 


\subsubsection{A colocação pronominal em OIP's: alguns perfis}

Os estudos sobre colocação pronominal no Português Brasileiro (PB), com base em peças teatrais e na literatura do romantismo, têm apontado a tendência crescente ao uso da próclise em todos os contextos linguísticos - início de sentença, grupos verbais, presença de advérbios e negação, etc. (CYRINO, 1993; SCHEI, 2002). Entretanto, na produção textual de alguns escritores da literatura brasileira, mormente romances narrativos do final do século XIX, dentre os quais podemos destacar José de Alencar, Visconde de Taunay e Machado de Assis, o uso da ênclise ocorre categoricamente diante da preposição a; ao passo que, diante das outras preposições, há variação:

Quando o infinitivo é preposicionado, a próclise ocorre em $28 \%$ dos casos e a colocação é em parte determinada pela preposição: com a há sempre ênclise, mas com as demais preposições há variação entre próclise e ênclise, esta última colocação sendo mais frequente com o pronome 0 do que com os demais pronomes. (SCHEI, 2002, p.74)

Galves e Abaurre (1996), analisando a fala culta urbana no final do século XX, aproximam o uso dos clíticos em orações infinitivas preposicionadas àquele que caracteriza a escrita modernista brasileira e o próprio falar hodierno, predominantemente proclíticos. A única exceção vai para os clíticos acusativos de $3^{a}$. pessoa, pois as autoras se centram no tipo de pronome e não fazem menção ao tipo de preposição, assim "a próclise ao verbo no infinitivo é a regra, menos para o/a, nos contextos em que o verbo é regido por preposição" (GALVES; ABAURRE, 1996, p.291).

Não obstante esses achados, uma tendência muito forte em direção à colocação pronominal enclítica no Brasil, no século XIX, é observada por Pagotto (1998) quando este analisa o estilo de dois exemplares do gênero discursivo considerado a expressão mais alta da elite do país: o texto constitucional. Como corpus, ele utiliza as Cartas constitucionais de 1824 e de 1891, que equivaleriam às cartas após a independência política, em 1822, e à proclamação da república, em 1889, respectivamente. Como já foi dito anteriormente, o autor identificou tendência proclítica da colocação pronominal na primeira constituição e enclítica na segunda. Na leitura de Pagotto (1998), o recrudescimento da ênclise na Constituição 
Republicana indicaria a adoção da variedade europeia da língua portuguesa do século XIX como modelo linguístico pela elite brasileira. A elite letrada do período republicano, extremamente europeizada e lusitanizada ${ }^{99}$, em atitude de conservadorismo linguístico, fixara como norma o modelo português de língua escrita:

[...] a gramática da constituição do Império é basicamente a norma do português clássico. [...] Dadas as características do português brasileiro atual, como explicar os resultados na constituição republicana [essencialmente enclítica]? É mais ou menos óbvio que eles refletem a norma culta lusitana atual, a mesma pela qual se guiam nossos manuais de gramática. O que chama a atenção é que, uma vez que os dois textos são de mesma natureza discursiva, espera-se que ambos tenham o mesmo grau de monitoração do uso linguístico. Por conseguinte, o texto da constituição do Império é uma mostra de que até 1824 a norma portuguesa para o texto escrito era uma; no final do século, já era outra. (PAGOTTO, 1998, p.39-40)

Da comparação dos dois textos, o autor registra o crescimento da ênclise no final do século XIX nas infinitivas:

Uma olhada agora nos resultados a partir do século XIX nos mostra um comportamento bastante semelhante aos verbos finitos no mesmo período. Repare-se como cresce a ênclise, apresentando-se a posição dos clíticos de maneira inversa à que seria esperada, se se parte de um PB atual essencialmente proclítico. (PAGOTTO, 1992, p.142)

A ênclise no texto constitucional republicano encontrada por Pagotto (1998) vai na contramão do crescimento da próclise apontado por Galves e Abaurre (1996), que analisaram amostras da fala culta. A opção das classes dirigentes por uma norma conservadora, que Pagotto interpreta como de matriz europeia, se opõe, portanto, à trajetória do vernáculo que se orienta pela próclise.

No que concerne mais especificamente ao PE, Martins (1994) descreve o comportamento dos clíticos em OIP's - considerando apenas as preposições $a$, de e pera, devido à escassez de dados referentes às outras preposições - tendo como corpus uma miscelânea de dados não literários dentre os quais predominam os

99 Ver seção 4.2.1. 
documentos notariais. Nesse trabalho, a autora analisa o português medieval dos séculos XIII e XIV, chegando a conclusões que mostram algumas similaridades entre este e o português do Brasil na virada do século XIX para o XX. Em relação à colocação dos clíticos em infinitivas com a preposição $a$, ela mostra ter havido uma mudança de posição da ênclise categórica, no século XIII, para a posição da próclise categórica já na segunda metade do século XIV. Em relação aos clíticos em infinitivas com a preposição de, há um uso categórico da próclise por todo o período analisado. Em infinitivas com a preposição pera, registrou-se variação entre próclise e ênclise por todo o século XIII, havendo uma mudança para a próclise categórica a partir da segunda metade do século XIV. Assim, a autora conclui que a colocação de clíticos em OIP's no português medieval se torna predominantemente proclítica já em meados do século XIV.

Ainda sobre os clíticos em OIP's no português europeu, o trabalho de Godoy (2006), que se concentra em autores clássicos do português europeu, mostra que houve uma mudança da próclise para a ênclise na colocação dos clíticos em infinitivas regidas pela preposição a, ao longo dos séculos XIV ao XIX:

[...] o comportamento do clítico nos casos das infinitivas preposicionadas também apresenta diferença em relação ao tipo de preposição. Com a preposição $a$, vemos que os clíticos saíram de um contexto de variação onde a próclise se fazia dominante, como era tendência no português arcaico, para um quadro essencialmente enclítico, sendo essa a norma no português europeu contemporâneo. Já observando a evolução no uso da ênclise nos outros ambientes, o das orações infinitivas introduzidas pelas preposições de, para, com, até, sem, em e por, podemos notar, entre eles, certa similaridade. Em todos os casos, encontramos inicialmente um ambiente proclítico, à imagem do que ocorria no português arcaico, e chegamos, por fim, a um ambiente de variação, onde as ênclises se fazem mais presentes que outrora. (GODOY, 2006, p.49)

O estudo diacrônico de Godoy (2006) aponta claramente o condicionamento do tipo de preposição na colocação pronominal, atentando para o crescimento do uso da ênclise em contexto da preposição "a", e a predominância do uso da próclise com as outras preposições em textos produzidos por escritores portugueses: 
Gráfico 1: Ênclise em OIP's ao longo dos séculos em Portugal

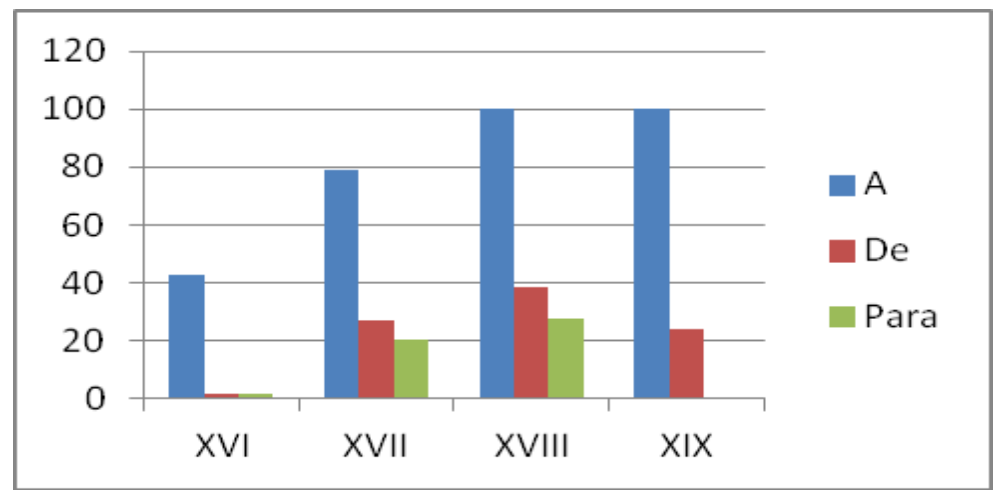

Adaptado de Godoy (2006, p.26-36)

Tomando por base os resultados de Godoy (2006), Oliveira (2011), que elabora análise comparativa de amostra constituída de cartas de escritores portugueses e brasileiros, revê a hipótese de Pagotto (1992) de que a elite brasileira do final do século XIX teria adotado a norma portuguesa de matriz europeia para a colocação pronominal. A análise aponta a ênclise como sendo categórica em infinitivas regidas pela preposição a entre escritores portugueses da virada do século $\mathrm{XIX}$ para o XX, enquanto a próclise seria usada com as preposições de e para; continuação da mudança iniciada nos dois séculos anteriores (Godoy, 2006):

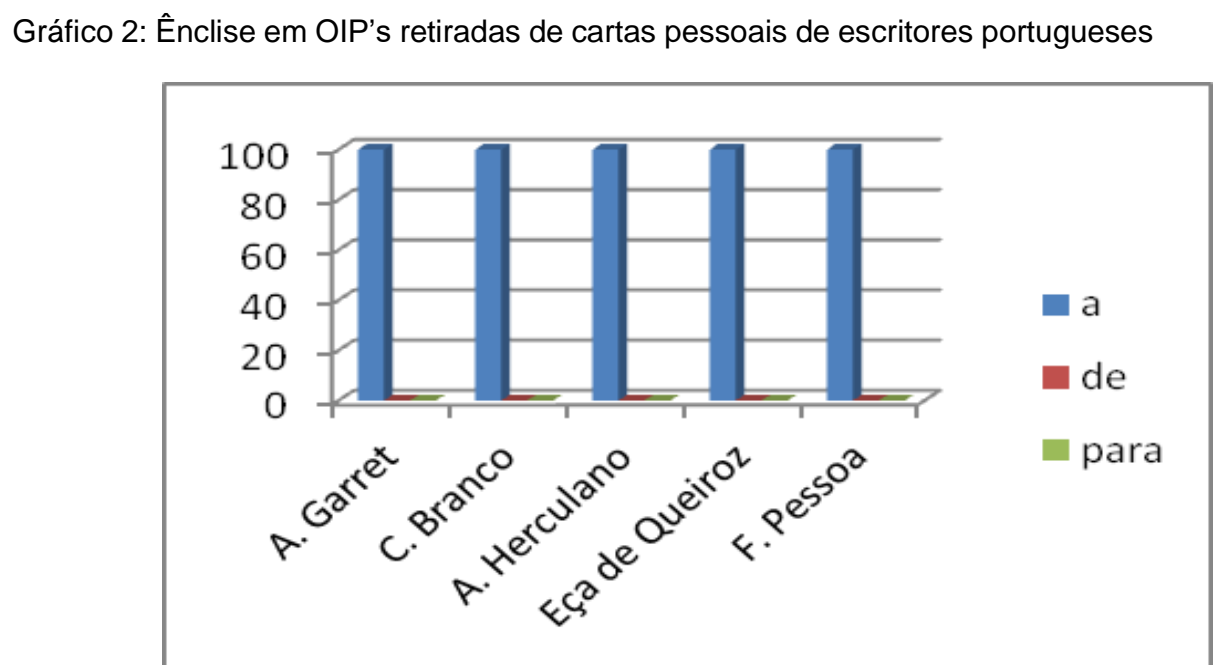

Fonte: Oliveira (2011, p.4)

Já o estudo da colocação pronominal em textos produzidos por escritores brasileiros, nesse mesmo período, mostra a preferência por um movimento que vai gradativamente da ênclise à próclise, com tendência a esta última à medida em que 
se aproxima o século XX (OLIVEIRA, 2011, p.5). Entre os modernistas, já no início do século $X X$, a próclise passa a ser categórica, o que reflete o vernáculo brasileiro e a escolha deliberada, por parte deles, para refutarem a norma linguística portuguesa de matriz europeia como modelo de língua:

Gráfico 3: Ênclise em OIP's retiradas de cartas pessoais de literatos brasileiros

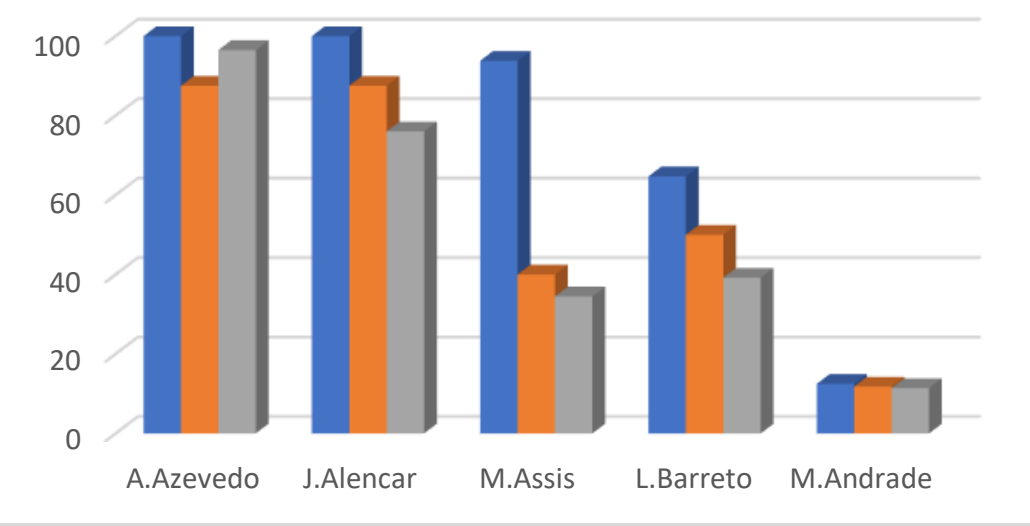

Fonte: Oliveira (2011, p.5)

O gráfico acima mostra a queda vertiginosa do emprego da ênclise no período final do Império e início da República observável nas cartas de Machado de Assis, Lima Barreto e Mário de Andrade, contrastando com a forte preferência pela ênclise na Constituição Republicana de 1891 e nos documentos produzidos por segmentos políticos republicanos, como mostra o resultado do trabalho de Santos Silva (2012):

Gráfico 4: Ênclise em OIP's entre os intelectuais republicanos paulistas

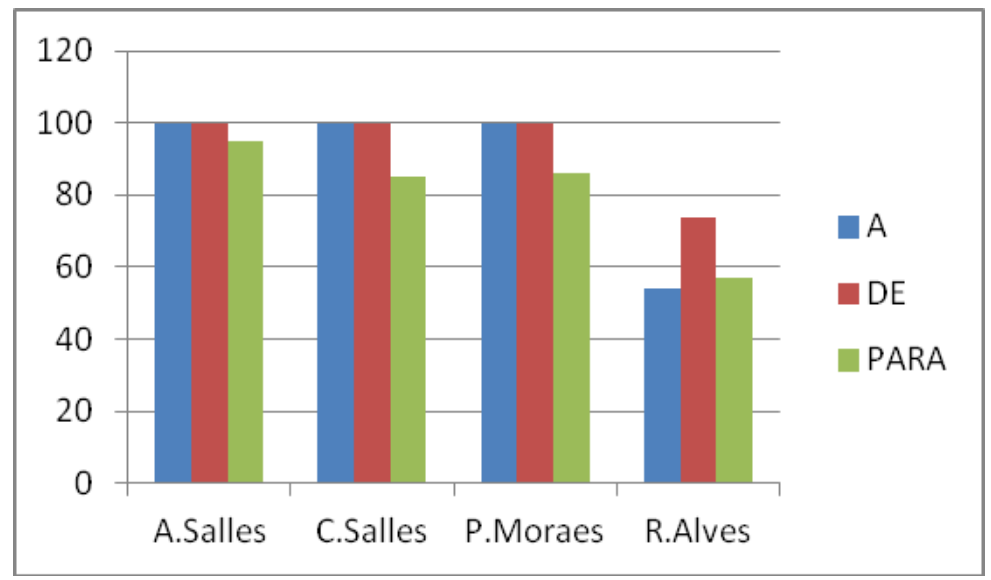

Fonte: Santos Silva (2012, p.274-276) 
O gráfico acima mostra claramente a preferência pela ênclise em qualquer contexto, ou seja, independentemente do tipo de preposição empregada. Esse fenômeno ocorre na escrita de um grupo de republicanos paulistas ${ }^{100}$, dos quais dois, Campos Salles e Prudente de Moraes $^{101}$, chegaram à presidência da República. A potencialização da ênclise nas produções escritas pela elite política republicana mostra que não seguia nem o PVB nem a norma linguística do PE. ${ }^{102}$ Não regulada nem condicionada por fatores linguísticos, a gênese da ênclise nesses textos deve ser tributária a fatores sociais. De fato, seus autores são políticos republicanos paulistas que encontraram um espaço nas fileiras do poder naquele entresséculos (ALONSO, 2002). A diferença no papel social dos autores dos textos está, portanto, na motivação da alta taxa de ênclise no período em que se verifica o avanço da próclise nesse mesmo contexto linguístico na variedade linguística vernacular.

Para melhor explorar a colocação pronominal na norma linguística adotada no Brasil, Oliveira (2013) analisou corpus de cartas de circulação pública de personagens pertencentes à classe política brasileira, tomando por base o período anterior à Independência (século XVIII), o Segundo Império e a virada do Império para a República, cujos resultados são apresentados a seguir:

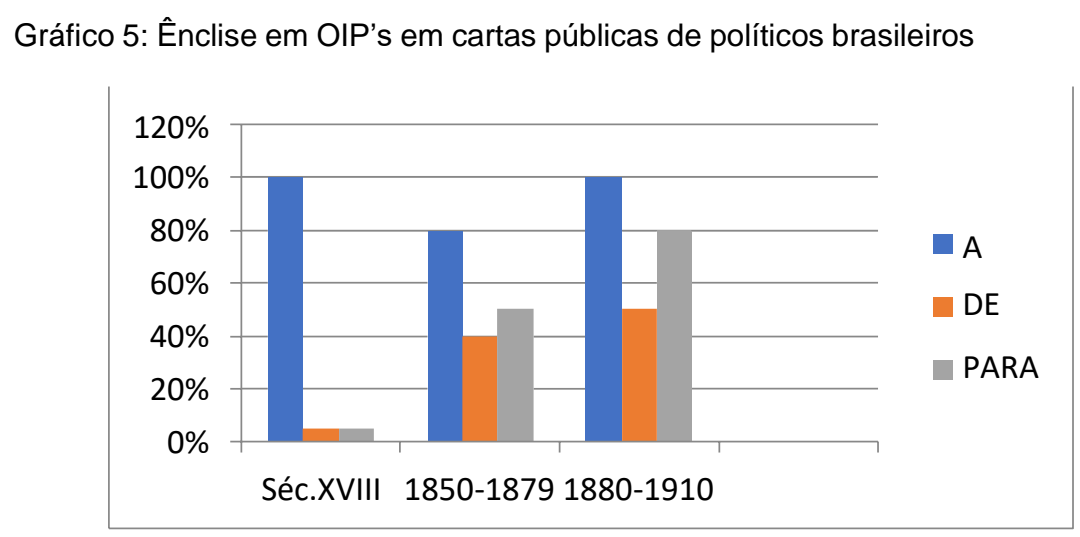

Fonte: Oliveira (2013, p.6)

\footnotetext{
100 Os irmãos Salles e Prudentes de Moraes pertenciam ao quadro de federalistas científicos de São Paulo. Apesar de a colocação pronominal de Rodrigues Alves apresentar ênclise indiferentemente do tipo de preposição que a rege, percebe-se claramente que a frequência da ênclise é bem inferior à dos federalistas científicos. Entretanto, é de se salientar que, ao contrário dos demais que estavam alijados do poder no período imperial, Rodrigues Alves foi conselheiro do Império e presidente da Província de São Paulo. (ALONSO, 2002, p.160)

${ }^{101}$ A família de Prudente de Morais esteve envolvida na criação de escolas protestantes como a Escola Metodista de Piracicaba.

102 Em Hack (2000) e Gomes (2001) é apresentado como Alberto Salles, Campos Salles, Prudente de Morais e Rodrigues Alves contribuíram para a instalação e o desenvolvimento da Escola Americana em São Paulo (Ver cap.2).
} 
O gráfico 5 demonstra a diferença de norma linguística entre os períodos colonial e imperial. Enquanto colônia, os textos de grupos políticos seguiam a norma linguística portuguesa - ênclise em presença da preposição "a" e próclise no contexto das demais preposições; os textos dos políticos no período imperial e republicano formam um quadro bastante heterogêneo, escapando da polarização do modelo português - colonial neste caso. A curva ascendente da ênclise no gráfico 5 se contrapõe à do gráfico 3, mostrando claramente dois modelos de escrita na virada do século XIX para o XX: a dos literatos e a dos políticos. A diferença de norma linguística adotada pelos escritores brasileiros, que adotaram a próclise, e pelos grupos políticos que adotaram a ênclise a partir do último quartel do século XIX, é explicada por Oliveira (2013) em termos de cisão nas atividades intelectuais, no sentido de que, a partir da década de 1870, os grupos políticos deixavam de se dedicar à literatura e os escritores não se lançavam mais à carreira política (Alonso, 2002, p.87). No âmbito linguístico, tal especialização é colhida na colocação pronominal: aqueles que se dedicam exclusivamente à política, adotam a ênclise; os que se dedicam à literatura, a próclise. ${ }^{103}$

Esses dados confirmam a intuição de Pagotto (1998) de que a elite política fazia uso indiscriminado da ênclise como marca de prestígio de um grupo, em contraste com a dos literatos que, procurando retratar as mudanças sociais da época, se direcionavam para a próclise que, em geral, reproduzia a fala do povo ou se aproximava dela. Entretanto, como sugere Oliveira (2013), o uso indiscriminado da ênclise mostra que a elite brasileira não se orientava apenas pelo padrão do português europeu em que a colocação pronominal em orações infinitivas se restringia ao contexto da preposição $a$.

Para além de mostrarem que a norma linguística brasileira não seguia somente a norma portuguesa, os resultados dos trabalhos de Oliveira $(2011,2013$, entre outros) sugerem a existência de comunidades linguísticas reconhecíveis por marcas sociais de prestígio que usam uma norma linguística peculiar, sobretudo no que diz respeito à colocação dos clíticos em OIP's. Portanto, podemos afirmar que

\footnotetext{
103 Essa segmentação, inexistente na 1a. metade do século XIX, é resultante da composição social da geração intelectual de 1870 que se encontrava marginalizada da dominação saquarema (ALONSO, 2002, p.87). Saquarema, nome proveniente de município do RJ, era o epíteto atribuído ao grupo de políticos conservadores. Seus oponentes eram conhecidos como luzias, nome dado aos liberais exaltados que combateram em Santa Luzia/MG.
} 
fatores extralinguísticos como o sentimento de pertença a um determinado grupo social e questões identitárias podem, sim, contribuir para a implementação de uma regra gramatical variável - como seria o uso categórico de ênclise entre os republicanos paulistas - com o intuito de delimitar uma distinção social. É impossível saber se esses grupos faziam uso consciente da regra ${ }^{104}$, pois a escolha da posição para o pronome átono, tal como outros fatos linguísticos, se faz intuitivamente ou intencionalmente através de comparações e por meio de condicionamentos, transições e encaixamentos decorrentes da avaliação acerca do valor social da marca linguística a ser implementada por indivíduos que integram uma mesma comunidade linguística (LABOV, 2008, p.314-326).

Em suma, reiterando o que sugerimos antes da análise quantitativa sobredita, no que concerne à colocação dos clíticos pronominais em OIP's, os resultados apresentam pelo menos quatro gramáticas diferentes:

- Português Europeu (PE): uso categórico de ênclise com a preposição a e uso categórico de próclise com as demais preposições;

- Português Vernácular Brasileiro (PVB): uso generalizado da próclise;

- Português da elite política republicana (PEPR): uso generalizado da ênclise;

- Português literário brasileiro (PLB): uso acentuado de ênclise, mas com margem de variação.

Esse panorama linguístico que apresenta pelo menos quatro gramáticas diferentes põe a seguinte questão: que padrão linguístico as escolas passam a veicular na cidade de São Paulo na virada do século XIX para o XX? Em particular, que padrão linguístico a comunidade Mackenzie, de forte apelo republicano, usa como modelo?

\footnotetext{
104 Geralmente, a opção pela próclise ou pela ênclise não é baseada no uso consciente da regra. É guiada pela pressão de tradições culturais e sociais, ou seja, é a herança de um patrimônio linguístico cujo valor é atualizado, ou se se preferir, emerge do concerto tácito entre os participantes de uma comunidade linguística (OLIVEIRA, 2011; 2013).
} 
Tomamos por hipótese que a convergência de ideais republicanos e a presença dos presbiterianos na organização da escola pública paulista são sinalizadores de uma aproximação linguística entre presbiterianos e intelectuais republicanos. Ou seja, os presbiterianos usariam a ênclise generalizada, tal qual no PEPR (SANTOS SILVA, 2012, p.274-276). Entretanto, essa aproximação entre presbiterianos e políticos republicanos paulistas pode ter se restringido à inserção dos protestantes na sociedade brasileira no período da crise do Império, o que nos faz pensar em uma segunda hipótese: uma vez inseridos, os protestantes podem ter adotado estratégias de alcance mais amplo para sobreviver no mercado da educação que se abrira na virada do século. Duas trilhas podiam ser seguidas para alcançar esse mercado: a escolha entre o PVB, substancialmente proclítico, e o PLB do último quartel do século XIX, caracterizado por acentuado uso da ênclise, mas com boa margem para o uso da próclise.

Para responder a esta questão, analisaremos a colocação pronominal em OIP's em textos produzidos na comunidade Mackenzie. Tendo em vista que os presbiterianos tiveram ações em diferentes atividades escolares, esta análise se restringirá à Escola Americana de São Paulo, posteriormente ressignificada e inscrita no complexo educacional Mackenzie College, cobrindo o período entre os anos de 1889 e 1923.

\subsection{Composição da amostra}

Entende-se por comunidade Mackenzie não somente a Escola Americana, mas também o Mackenzie College, que desenvolveu atividades em cursos superiores, como os de arquitetura e engenharia.

Para esse estudo, levantou-se o seguinte material:

- eschola Americana. Cartas aos paes de nossos alumnos. São Paulo, 1889-1899. (10 edições)

- ESCHOLA AMERICANA; MACKENZIE COLLEGE. Prospectos. São Paulo, 1893-1899.

- REVISTA PROGRESSO. São Paulo, 1908-1909. (2 edições) 
- ReVista de engenHARIA do MACKEnZIE COllege. São Paulo, 19151920. (21 edições)

- REVISTA AVATAR. São Paulo, 1917-1918. (2 edições)

- DISCURSOS DE PARANIMPHOS, 1915-1923 (11 edições)

\subsection{Bases teóricas e pressupostos metodológicos}

A análise da colocação pronominal em OIP's tomará por corpus o conjunto dos textos supracitado, procedendo ao estudo do uso variável de clíticos pronominais em textos produzidos pela comunidade Mackenzie no entresséculos XIX-XX, de 1889 - quando se inicia a chamada Primeira República - até 1923.

Apesar de considerarmos o aporte teórico-metodológico da sociolinguística variacionista insuficiente para se compor um panorama histórico e social abrangente no que concerne ao estudo da variação linguística, o método de pesquisa utilizado nessa subárea da linguística se mostra bastante eficaz, sobretudo, na realização de análises quantitativas. Por isso, utilizaremos parte de seu instrumental teórico neste trabalho. Diferentemente da sociolinguística de caráter mais laboviano, que tem como objeto de pesquisa a língua falada, lidamos com um corpus constituído por dados históricos cujo registro se encontra na modalidade escrita da língua portuguesa, o que nos faz abrir mão de ferramentas como entrevistas e questionários avaliativos, por exemplo. Nos interessam, contudo, considerações teórico-conceituais que consideram a língua como um organismo de variação intrínseca não-arbitrária, cujos fundamentos estão na teoria de variação e mudança proposta por Weinreich, Labov e Herzog (1968) e Labov (1972) e (2001), embora saibamos que esse mesmo modelo teórico não privilegia constituintes morfossintáticos (objeto de análise deste trabalho) como variáveis linguísticas em suas pesquisas, dando preferência a variáveis fonológicas (LAVANDERA, 1977; LABOV, 1978).

Observaremos a ordem dos clíticos pronominais como um fenômeno de variação, partindo do pressuposto de que o comportamento dos pronomes átonos que constituem a variável dependente - é motivado por fatores internos e externos à 
própria língua, ou seja, as variáveis independentes, sabendo-se que condicionamentos linguísticos (estruturais) e extralinguísticos (sociais) presidem a regra variável, de acordo com o que ficou conhecido, na teoria da variação e mudança, como o "problema das restrições" (WEINREICH, LABOV e HERZOG, 1968; LABOV, 1972). Desse modo, considerando-se os fatores constitutivos da variável dependente no âmbito das OIP's, serão investigados os grupos de fatores as restrições - possivelmente responsáveis pelo condicionamento do fenômeno em variação. Todavia, não analisaremos os dados linguísticos numa perspectiva diacrônica aos moldes da teoria da mudança linguística de Weinreich, Labov \& Herzog (1968). Nossa análise compara diferentes usos de uma mesma variável morfossintática, realizados por diferentes grupos sociais ou comunidades linguísticas num mesmo recorte temporal, ou seja, numa mesma sincronia pretérita.

Ferramentas de outras ramificações dos estudos linguísticos também serão úteis em nossa análise, como é o caso de alguns procedimentos metodológicos da Sociolinguística histórica. Isso porque, como se sabe, o corpus deste trabalho é constituído por dados históricos cujo registro foi realizado na modalidade escrita da língua portuguesa. A Sociolinguística histórica considera que as fontes documentais do passado, que possibilitam o estudo sócio-histórico da língua, são "fragmentárias, escassas e dificilmente vinculáveis à produção real de seus falantes" (CONDE SILVESTRE, 2007, p.35; LOPES, 2018, p.14-16). Assim, o tratamento do corpus também deve levar em consideração os seguintes aspectos:

- Na maioria das vezes, dados do passado são escassos e fragmentados, fazendo com que o pesquisador se oriente pela máxima laboviana de fazer o melhor uso possível de maus dados (LABOV, 2001, p.11);

- Dados do passado sobreviveram ocasionalmente e apresentam vieses específicos, por isso, dificultam o controle de fatores externos à língua relacionados a informantes não mais presentes (idade, escolaridade, gênero, classe social etc.);

- Dados do passado foram produzidos por informantes alfabetizados e, no limite, escolarizados. Em geral, trata-se de homens brancos das classes sociais média e alta, o que lhes dá a condição de avaliar a língua que usam numa atitude para a linguagem quase sempre normativa e prescritiva, 
tentando aproximar sua escrita da variedade padrão estandardizada que era utilizada à época;

- Dados do passado são lacunares e heterogêneos, apresentando estilos e registros restritos, o que dificulta a análise, dependendo de seus objetivos;

- Novos dados do passado podem aparecer com o tempo, preenchendo lacunas em análises que já foram feitas e estimulando o pesquisador a realizar pesquisas de longa duração, a medida em que novos dados forem sendo incorporados a ela;

- A escassez de dados do passado faz com que o pesquisador tenha que trabalhar com corpora múltiplo e diversificado, envolvendo gama variada de gêneros discursivos, de acordo com a disponibilidade de dados. Se por um lado, essa estratégia pode tornar a análise superficial, por outro, oferece uma visão mais ampla do objeto estudado.

O trabalho se concentrará no estudo da variável "colocação pronominal em OIP's". O objetivo é verificar se o padrão linguístico adotado pela comunidade Mackenzie apresenta a colocação pronominal em OIP's como no Português Europeu (PE); ou como no Português Vernacular Brasileiro (PVB); ou como no Português da elite política republicana (PEPR); ou ainda como no Português literário brasileiro (PLB) do último quartel do século XIX.

Dentre as várias possibilidades de colocação de clíticos em OIP's, foram selecionados alguns fatores internos à língua e excluídos outros para que houvesse mais regularidade na amostra.

Foram selecionados os seguintes fatores linguísticos:

1) tipo de clítico (todos);

2) forma verbal: infinitivo não flexionado;

3) posição do clítico: ênclise e próclise ao verbo no infinitivo;

4) tipo de conectivo: as preposições a, de e para.

Foram excluídos os seguintes fatores linguísticos: 
5) presença de combinação de pronomes:

Aos assignantes que não receberem algum numero da Revista, pedimos o obsequio de nol-o reclamar directamente... (REVISTA DE ENGENHARIA, junho de 1917, G. Bierrembach Lima, p.43)

(6) presença de advérbios e operadores de negação:

...estás acostumado a não me ouvir... (REVISTA PROGRESSO, fevereiro de 1908, p.18)

7) presença de grupos verbais:

Para se poder calcular o mínimo de intensidade admissível para uma fonte, é necessário saber qual o fim especial da illuminação. (REVISTA DE ENGENHARIA, 1915, p.38)

8) pronomes em construções coordenadas (neste caso foi levada em conta apenas a ocorrência próxima à preposição):

[...] carácter sério, convicções fortes sobre muitas cousas, e coragem de sequil-as e pol-as em prática [...] (ESCHOLA AMERICANA, 1897.)

9) pronomes em orações com verbos infinitivos flexionados ${ }^{105}$ :

Em epoca mais recente nos apparece o vulto saudoso e notavel de Horace Lane, que diariamente contemplaes em ephigie no nosso jardim e pelo qual não deveis passar sem vos descobrirdes respeitosamente. (REVISTA DE ENGENHARIA, 1915, p.68)

A análise variacionista tomará como condicionantes os seguintes grupos de fatores:

105 "Que o ouvido tem de ser consultado, prova-o melhor ainda o caso do infinitivo com flexão pessoal. Basta a sílaba átona da desinência para que ao português clássico repugne o acréscimo do pronome, isto é, de outra sílaba átona. Aqui todas as regras supramencionadas relativas ao infinitivo, tendo expressa uma das preposições em, de, para, sem, até, com, sobre, e exigindo ou tolerando o pronome pós-verbal, perdem a sua validez. O pronome aqui recua sistematicamente para antes do verbo. [...]" (SAID ALI, 2008, p.29-35) 
a) Fatores extralinguísticos do tipo autor, data e gênero textual $\rightarrow$ Foram estudados autores que integram a comunidade linguística da Escola americana e Mackenzie College, no período de 1889 a 1923, em textos já mencionados no item Corpus;

b) Tipo de preposição $\rightarrow$ As preposições a, de e para são as que aparecem com mais frequência no corpus, por isso, foram escolhidas e submetidas a uma apreciação de ordem quantitativa e a uma análise qualitativa. ${ }^{106}$

Preposição a:

10) ...habilita os alumnos a adquirirem um conhecimento mais seguro das materias estudadas, sem serem obrigados a desviar-se do curso systematico, a preparar pontos, ou a accommodar se a um systema que póde ser-lhe util em uma só direcção. (PROSPECTO MACKENZIE, 1893, p.08)

11) ...darão o volume total a se fornecer durante as 24 horas de consumo. (REVISTA DE ENGENHARIA, 1915, p.18)

Preposição de:

12) ...a vossa intelligencia não tenha de espraiar-se por novos e ainda não vistos horizontes... (REVISTA DE ENGENHARIA, 1916, p.58)

13) ... até que as pupilas tenham tempo de se contrahir e a retina de se acostumar ao novo regimen (REVISTA DE ENGENHARIA, 1915, p.37)

Preposição para:

14) ...e para ter-se a projecção do mesmo lado... multiplica-se o comprimento... (REVISTA DE ENGENHARIA, 1916, p.07)

15) É para se conseguir esse desideratum... (REVISTA DE ENGENHARIA, 1916, p.60)

c) Tipo de clítico pronominal $\rightarrow$ serão considerados todos os tipos de clíticos pronominais nessa pesquisa (nas diferentes funções sintáticas e nas diferentes pessoas gramaticais):

${ }^{106}$ Além das três preposições selecionadas, foram encontradas no corpus as preposições até, em, sem e por que, juntas, constituem menos de $10 \%$ dos dados analisados. 
16) ... será muito melhor reforçal-as com chapas rebitadas nas sapatas a trocal-as por outra espécie de viga (REVISTA DE ENGENHARIA, 1915, p.24)

17) ...quero eu despedir-me de vós; com este conselho de amigo, $\underline{a}$ bailar-vos no ouvido... (REVISTA DE ENGENHARIA, 1915, p.62)

18) Quando acorrestes ao meu gabinete, a convidar-me para vosso paranympho... (REVISTA DE ENGENHARIA, 1915, p.56)

19) Quando existir necessidade de se empregar tubos de diametros maiores de $0.50 \mathrm{~m} . .$. (REVISTA DE ENGENHARIA, 1915, p.22)

20) ...marcha na vanguarda da intellectualidade humana na árdua tarefa de oriental-a... (REVISTA DE ENGENHARIA, 1915, p.70)

21) ...que perante vós, principalmente perante vós, Exmas Senhoras! Assumamos o compromisso de alliar-nos para sempre, com amor e fidelidade, ao progresso e ao engrandecimento da República! (REVISTA DE ENGENHARIA, 1915, p.65)

22) ...os futuros adeptos da theoria do movimento perpetuo , antes de lhe tentar o descobrimento... (REVISTA DE ENGENHARIA, 1916, p.10)

23) ... decorre a luta persistente com os elementos naturaes e todos os nossos arremessos para dominal-os. - (REVISTA DE ENGENHARIA, 1915, p.58)

24) ...como a precisa autoridade para dar-vos 0 derradeiro conselho... (REVISTA DE ENGENHARIA, 1915, p.56)

25) ...a mathematica está de tal modo constituida, que nada lhe poderá alterar a doutrina, seja para ampliar-lhe o poder, seja para amesquinhá-la. (REVISTA DE ENGENHARIA, 1916, p.09)

26) ...Nesse anno deixou o cargo do Museu para dedicar-se exclusivamente á Commissão Geologica de S. Paulo... (REVISTA DE ENGENHARIA, 1915, p.53)

\subsection{Resultados da análise da colocação pronominal na comunidade mackenzista}

A análise da amostra mackenzista, constituída de 245 dados, sinaliza uma concorrência entre próclise e ênclise, com leve tendência à segunda (132/245 ocorrências de ênclise, perfazendo 54\%): 


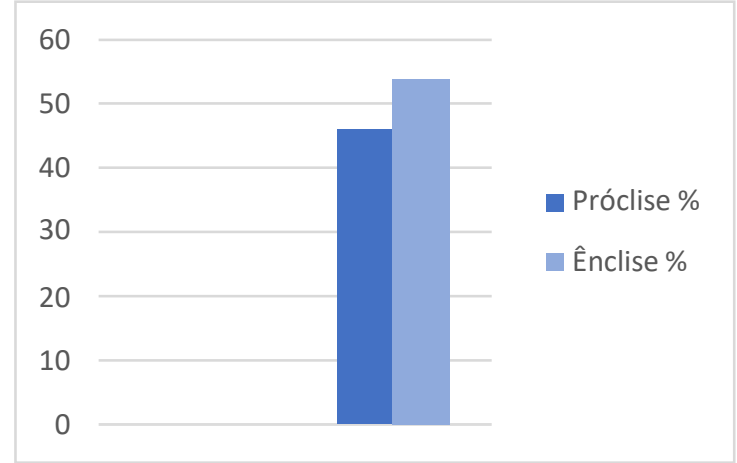

O quadro delineado pelo estudo sobre a presença de próclise e ênclise em OIP's nos textos produzidos pela comunidade Mackenzie mostra um padrão de uso indefinido, devido à pequena vantagem no uso da ênclise (8 pontos percentuais). Entretanto, há que sinalizar que a próclise está próxima dos $40 \%$ e a ênclise quase atingindo os $60 \%$, o que mostra leve tendência ao uso da ênclise.

Ao se particularizar a análise, em função do peso do tipo de preposição, observa-se que esse fator linguístico demonstra grande relevância:

Gráfico 7: Colocação pronominal de acordo com preposições

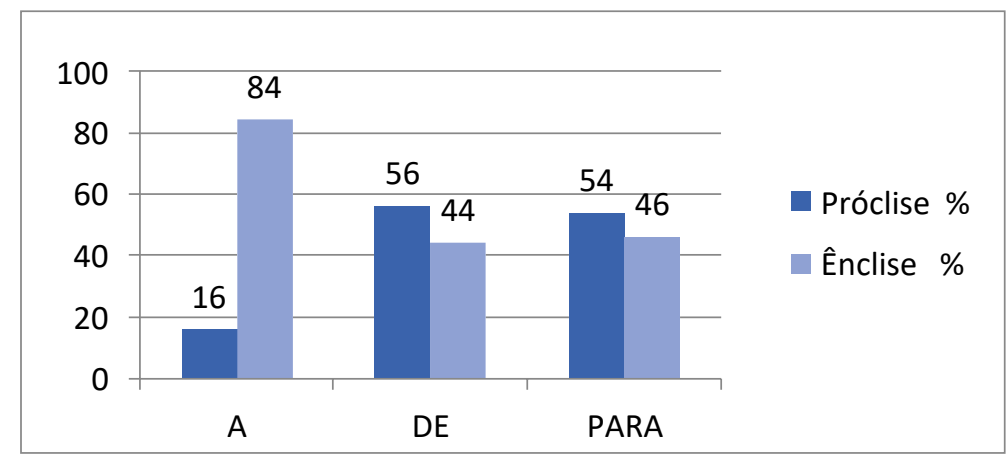

A ênclise é predominante em infinitivas com a preposição a (84\%) sem, contudo, alcançar o comportamento linguístico de uso categórico, como acontece na matriz europeia. A pequena participação da próclise (16\%), no entanto, se mostra irrelevante nesse ambiente sintático, o que sugere um primeiro distanciamento do vernáculo brasileiro que já apontava próclise como traço peculiar. Desse modo, pode-se afirmar que a preposição a propulsiona 0 uso da ênclise, independentemente do tipo de pronome: 
27) ...habilita os alumnos a adquirirem um conhecimento mais seguro das materias estudadas, sem serem obrigados a desviar-se do curso systematico, a preparar pontos, ou a accommodar se a um systema que póde ser-lhe util em uma só direcção. (PROSPECTO MACKENZIE, 1893, p.08)

28) O estudo destas linguas [francês e inglês] no primeiro anno, é principalmente, o de grammatica e conversação, no segundo e terceiro annos ellas tornam-se um meio de estudo, e os seus professores se esforçam com o fim de acostumar os alumnos a usalas correctamente. (PROGRAMMA do curso superior da eschola americana, 1894, p.09)

29) Temo-nos esmerado em preparar o Internato para meninas de modo a proporcionar-lhes todos os comfortos e garantias que se devem achar n'uma familia bem organizada. (PROSPECTO MACKENZIE, 1900, p.37-38)

30) 'E amando ardentemente as paizagens, as scenas e a alma da nossa terra que aprenderemos como elles, a defendel-a um dia... (REVISTA PROGRESSO, 1908, p.09)

31) Se o engenheiro fôr encarregado de levantar somente o perímetro ou uma polygonal, o methodo a seguir-se será o de caminhamento... (REVISTA DE ENGENHARIA, 1915, p.41)

32) ... darão o volume total a se fornecer durante as 24 horas de consumo. (REVISTA DE ENGENHARIA, 1915, p.18)

33) ...do regimem das aguas que nos foi assignalado; nossas previsões poderiam, pois, ser ultrapassadas, si estas condições viessem a se aggravar... (REVISTA DE ENGENHARIA, 1916, p.58)

O ambiente das demais preposições traz a competição entre próclise e ênclise, pois há alto índice da primeira (56\% e 54\%, no caso das preposições "de" e "para", respectivamente), configurando outra particularidade que afasta a matriz europeia como possível modelo para a comunidade mackenzista haja vista que, nesse contexto, a próclise é absoluta no PE.

Quanto ao fator pronominal, observa-se que o tipo de clítico não oferece nenhuma restrição ao uso da ênclise em infinitivas com a preposição $a$. Tem-se desde formas acusativas de $3^{a}$. pessoa a formas dativas, reflexivas e índice de indeterminação do sujeito. Nas nove ocorrências de próclise em infinitivas com a preposição $a$, tem-se um perfil diferente ao verificado com a ênclise devido à ausência de clíticos acusativos de $3^{a}$. pessoa nessa posição (o que desde sempre prescrevem as gramáticas normativas respaldadas pelo argumento da eufonia. $O$ 
que há como próclise são os clíticos me e nos, de 1a. pessoa e o clítico se significando índice de indeterminação do sujeito e reflexivo. Entretanto, o clítico se também aparece em posição enclítica (veja os exemplos 10, 12, 14, 26, 27 e 31 acima).

Já no caso da próclise em infinitivas com as demais preposições (de e para), verifica-se competição pari passu com a ênclise, o que sugere haver uma distribuição muito heterogênea quanto às possibilidades de próclise e ênclise em orações infinitivas preposicionadas encontradas nos textos produzidos pelo Mackenzie:

34) Não deixa de ter o perigo de nos attrahir ao lado utilitário em prejuízo do educativo [...] - (ESCHOLA AMERICANA, 1892)

35) Procuramos desenvolver a intelligencia afim de poder saber, em logar de enchel-a com formulas fixas. (PROSPECTO MACKENZIE, 1897, p.13)

36) Augusto arranjava meios de frequental-a, e nas reuniões que davam eram mais occasiões de encontrar-se com a pequena (REVISTA PROGRESSO, 1909, p.14)

37) A luz directa do sol produz uma illuminação exessivamente brilhante, que fatiga rapidamente os orgãos visuaes; mas a Natureza encarregou-se de lhe velar o brilho... (REVISTA DE ENGENHARIA, 1915, p.37)

38) Os alumnos que chegam tarde devem trazer cartão, ou bilhete, dos paes ou tutores, para desculpal-os da tardança. (PROSPECTO MACKENZIE, 1901, p.04)

39) A corrente necessaria para fazer funccionar o cleptographo é o de uma pilha ordinária, podendo-se usar a da luz electrica por meio de resistencias para enfraquecel-a. (REVISTA PROGRESSO, 1909, p.22)

40) Para se obter um resultado satisfatório, é necessário que a curvatura seja estudada... (REVISTA DE ENGENHARIA, 1915, p.14)

41) As correntes de agua que percorrem os tubos são poderosas e para as diminuir existem, junto ás sahidas, outras valvulas que servem de controlle... (Op. Cit., 1916, p.26)

O pronome se, mormente na função de indeterminador do sujeito, aparece na maioria das vezes na posição proclítica (64\%). Entre as formas de 3a . pessoa, o clítico se é o que mais aparece proclítico, mormente na função de indeterminador de 
sujeito (64\%). Já os clíticos acusativos o / $a$, de 3 a . pessoa, são os que mais acionam a posição enclítica (82\%):

Tabela 4: Colocação pronominal $X$ tipo de pronome

\begin{tabular}{l|ll|ll}
\hline & \multicolumn{2}{|l|}{ Próclise } & \multicolumn{2}{l}{ Énclise } \\
& oc. ${ }^{107}$ & $\%$ & oc. & $\%$ \\
SE & 78 & 64 & 44 & 36 \\
O/A & 16 & 18 & 68 & 82 \\
LHE & 03 & 30 & 07 & 70 \\
ME/NOS & 09 & 45 & 11 & 55 \\
VOS & 07 & 78 & 02 & 22 \\
\hline
\end{tabular}

Gráfico 8: Colocação X tipo de pronome

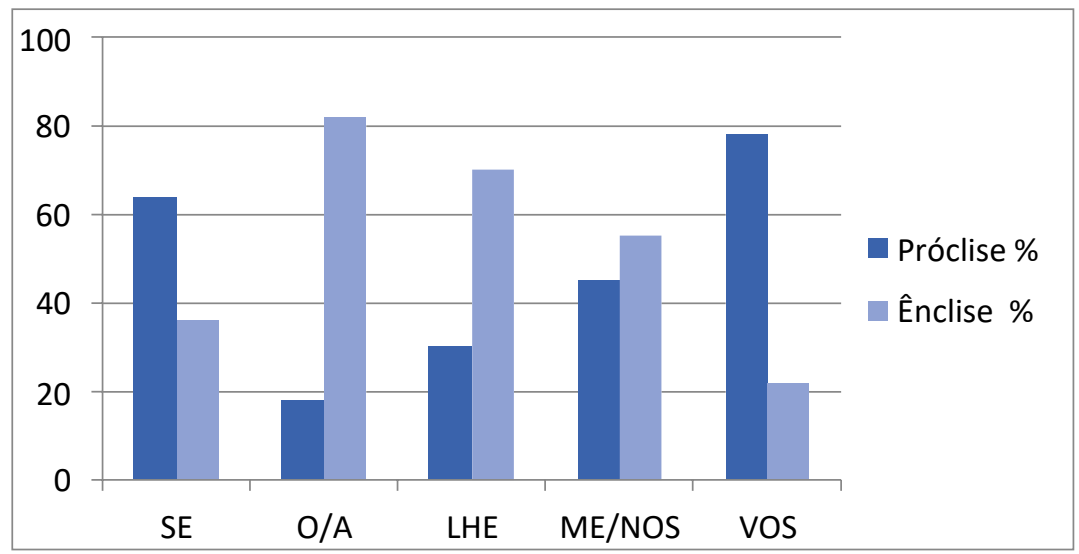

Para observarmos se a próclise era condicionada apenas pelo tipo de pronome ou pelo tipo de preposição, correlacionamos esses dois fatores, cujos resultados estão representados abaixo:

107 Indicamos os números de ocorrências (oc.) seguidos dos percentuais (\%). 


\begin{tabular}{l} 
Tabela 5: Ênclise: correlação de pronome e preposição \\
\hline
\end{tabular}

Gráfico 9: Ênclise: correlação de pronome e preposição

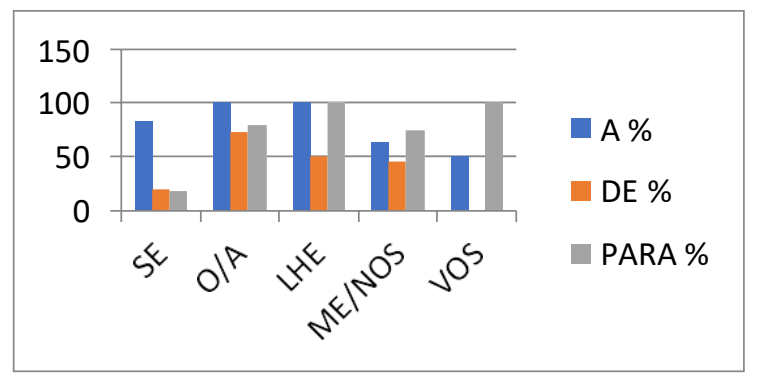

No gráfico acima, as barras azuis referentes à preposição a sugerem que esta exige ênclise da maioria dos pronomes. A motivação fonológica que embasa a eufonia, argumento de que se servem os gramáticos do início do século $X X$, não é suficientemente robusta para explicar a colocação pronominal do material em exame, haja vista que no ambiente da preposição a a ênclise é acionada independentemente do tipo pronominal. Por sua vez, a preposição para aciona mais a ênclise com todos os clíticos, exceto se (19\%); e a preposição de aciona mais a ênclise com o acusativo de $3^{3}$ pessoa o/a (74\%). Esses dados sugerem que, se as preposições a e para fazem carga na colocação enclítica dos pronomes, os pronomes acusativo (o/a) e dativo (Ihe) de 3‥ pessoa, singular e plural, parecem ser os mais suscetíveis a essa colocação. Já o pronome se, acompanhado pelas preposições de e para, é mais resistente à ênclise. Por outro lado, na presença da preposição a, o pronome se faz desencadear a ênclise.

Com essas observações, chega-se ao ponto central deste trabalho: o de tentar explicar a ênclise em OIP's, correlacionando as escolhas sintáticas ao perfil 
sócio-histórico da comunidade linguística Mackenzie através de sua produção escrita.

Comparando os resultados obtidos a partir da amostra mackenzista com aqueles obtidos por Oliveira (2011), observamos que a produção da comunidade Mackenzie, por não polarizar a ênclise com a preposição a e a próclise com todas as outras preposições, não adota o modelo europeu da língua portuguesa. Também não segue o padrão dos políticos republicanos paulistas no poder (SANTOS SILVA, 2012), pelo fato de estes potencializarem a ênclise em todos os contextos, chegando ao índice de $100 \%$ no contexto de duas ou mais preposições; o padrão da escrita da elite política em geral tende a reforçar a ênclise (OLIVEIRA, 2013), o que ocorre num grau bem menor no material da comunidade Mackenzie. Já o modelo vernacular, essencialmente proclítico, mostra um espectro relativamente amplo se se pensa na curva descendente da ênclise que vai de escritores como José de Alencar a Mário de Andrade. Além disso, a própria avaliação social feita pela comunidade Mackenzie, em torno das variáveis linguísticas prestigiadas e desprestigiadas, nos leva a crer que esse grupo não usaria o vernáculo brasileiro como modelo de língua a ser seguido, o que de fato não aconteceu.

Da comparação dos índices percentuais, observamos que a gramática usada no Mackenzie se aproxima da gramática de alguns escritores brasileiros do século $X I X$, nomeadamente aqueles que se encontram entre os que tentavam criar uma língua literária brasileira (SILVA NETO, 1986, p.12).

Em trabalho sobre a colocação pronominal em escritores do século XIX, Schei (2002) analisou seis escritores por meio de seus respectivos romances: Joaquim Manuel de Macedo - A Moreninha; José de Alencar - Lucíola; Bernardo Guimarães - O garimpeiro; Manuel Antônio de Almeida - Memórias de um sargento de milícias; Visconde de Taunay - Inocência; e Machado de Assis - Dom Casmurro. O estudo mostrou que, em contexto de OIP's, a ênclise é categórica diante da preposição a (100\%) e aparece em $72 \%$ dos casos diante das outras preposições. Comparando Shei (2002) à quantidade de ênclises encontradas no material produzido pelo Mackenzie, temos o seguinte quadro: 
Gráfico 10: Ênclise Mackenzie X escritores românticos do séc. XIX108

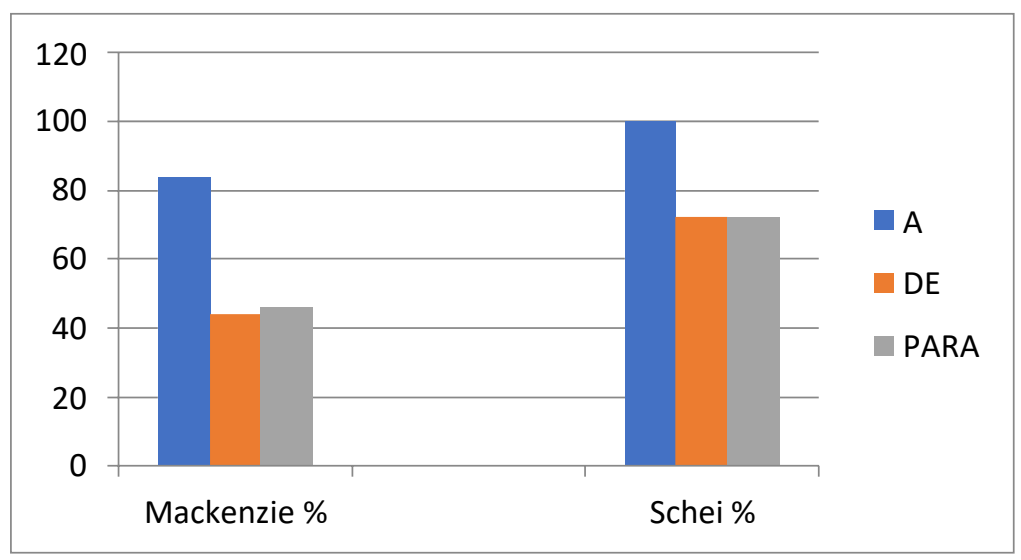

Fonte: Schei (2002, p.70)

Embora os índices não sejam exatamente os mesmos, impressiona a semelhança entre os desenhos gráficos, além da proximidade numérica entre o Mackenzie e os escritores estudados por Schei (2002). Quando a análise consiste em quantificar os clíticos em cartas pessoais de um desses escritores (OLIVEIRA, 2011), especificamente, e compará-la com a gramática do Mackenzie, verifica-se maior alinhamento entre a colocação pronominal usada nessa instituição e a dos escritores do último quartel do século XIX. Ao darmos zoom na colocação pronominal desses escritores, verificamos que é nas cartas pessoais de Machado de Assis que se acha o perfil e a frequência que mais se aproximam do comportamento linguístico observado nas produções mackenzistas, como se observa no gráfico a seguir:

108 Colhemos de Schei (2002, p.70) os dados referentes aos romances de escritores românticos. 


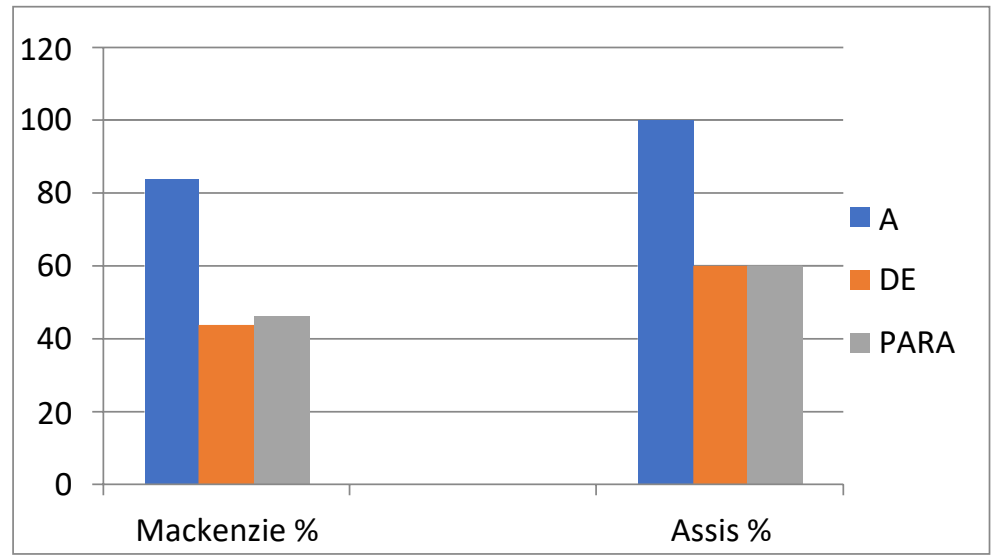

Fonte: Oliveira (2011, p.17)

A aproximação no perfil e na distribuição numérica da ênclise entre Machado de Assis e as produções escritas do Mackenzie sugerem que essa comunidade não se orientou pelo PVB mais "progressista", como o de modernistas do quilate de Mário de Andrade (ver gráfico 3), afastando-se, também, seja da gramática do PE, que prevê a ênclise categórica no contexto da preposição "a" e a próclise absoluta com as preposições "de" e "para", seja do PEPR, que potencializa a ênclise em todos os contextos (gráfico 4).

Essa hipótese é reforçada pelo fato de o Mackenzie College estudar alguns desses escritores românticos (Visconde de Taunay e José de Alencar) em seus cursos superiores. A possibilidade de que a escrita da comunidade Mackenzie tenha sido "influenciada" pelos escritores se confirma ao se analisar os prospectos do Mackenzie College. Segundo esses prospectos, o curso de Língua Portuguesa era subdividido em cinco grandes áreas:

Quadro 7: Programa de estudos de língua portuguesa

\begin{tabular}{|c|c|c|c|c|}
\hline Lingua Portugueza & $\begin{array}{l}\text { Historia da } \quad \mathrm{Li} \\
\text { Portugueza }\end{array}$ & Litteratura & $\begin{array}{l}\text { Historia } \\
\text { Litteratura }\end{array}$ & $\begin{array}{l}\text { Historia } \\
\text { Litteratura brasil }\end{array}$ \\
\hline $\begin{array}{l}\text { Compendio: Julio Ri } \\
\text { - Grammatica Portug }\end{array}$ & $\begin{array}{l}\text { Compendios: } \\
\text { Vasconcellos } \\
\text { Grammatica Historic: }\end{array}$ & $\begin{array}{l}\text { Simões } \\
\text { Noções } \\
\text { Litteratura Nad }\end{array}$ & Simões Dias: ibi & $\begin{array}{l}\text { Compendio: } s \\
\text { Romero e } \\
\text { Ribeiro - Histori }\end{array}$ \\
\hline $\begin{array}{l}\text { Leitura: Escrip } \\
\text { contemporaneos - } \\
\text { de Visconde de Taun }\end{array}$ & $\begin{array}{lr} & \\
\text { Leitura: } & \text { escrin } \\
\text { romanticos. } & \text { Jose } \\
\text { Alencar, } & \text { Herculan } \\
\text { Garret } & \end{array}$ & $\begin{array}{l}-\quad \text { Theoria } \\
\text { Litteratura e } \mathrm{Hi} \\
\text { Litteraria }\end{array}$ & $\begin{array}{l}\text { Leitura: - Ca } \\
\text { Sta. Rita Durã } \\
\text { outros clássicos }\end{array}$ & Litteratura \\
\hline
\end{tabular}


Não por acaso, verifica-se a presença das obras de Visconde de Taunay no compêndio do estudo da língua e a presença de José de Alencar nos estudos de História da Língua Portuguesa. Além disso, a publicação de alguns contos de Machado de Assis na revista Avatar mostra que esse público também o lia em seu cotidiano acadêmico. A presença desses três escritores no cânone de estudos da língua, e não apenas para estudos literários, reforça a tese de que a comunidade Mackenzie adotava uma norma gramatical semelhante ao PLB, haja vista a análise da colocação pronominal em OIP's. A maior proximidade entre a norma linguística mackenzista e a adotada por Machado de Assis talvez se deva ao fato de que seus textos (e os de Coelho Neto e Olavo Bilac) eram publicados na revista Avatar, cujas temáticas inclinavam para as questões nacionalistas a partir da tríade raça, religião e língua (CHAUÍ, 2002). Se todos dominavam um vernáculo, poucos tinham acesso a uma norma culta. Menos ainda - os escolhidos - tinham acesso à norma que tendia a se firmar como nacional.

Diferentemente da primeira hipótese suscitada - que considerava que o Mackenzie fosse se aproximar do PEPR, em oposição aos monarquistas verificamos que o Mackenzie, em seu pioneirismo no ensino de Língua Portuguesa, escolheu escritores brasileiros para compor o seu cânone fazendo jus e se inserindo no ambiente intelectual que tinha por projeto a construção de uma nação brasileira pautado nas questões de raça, religião e língua. $O$ romantismo representado por alguns escritores contemporâneos ao início das atividades do Mackenzie College registra um padrão de colocação pronominal brasileiro (SCHEI, 2002, p.71), e o Mackenzie College adota essas mesmas regras de colocação pronominal, distanciando-se tanto da gramática do português europeu quanto daquela usada pela elite política republicana.

Para o projeto de nação brasileira, sonhado pelos protestantes mackenzistas, a língua não poderia ser aquela do colonizador, principalmente pelo comprometimento deste com o Catolicismo. A busca por um modelo local se mostrava adequada para compor o cânone de leitura escolar. Assim, tem início a formação da norma culta paulista para se opor à norma culta portuguesa. Por conseguinte, distanciar-se linguisticamente de Portugal (PE) é uma maneira de esvaziar a língua portuguesa de sua carga simbólica católica e imperial, considerada um atraso para os protestantes, cujos ideais republicanos e democráticos serviam 
melhor à instauração do capitalismo liberal encarado por eles como missão divina. A escrita da elite republicana (PEPR) é aparentemente desconhecida dos mackenzistas, reverberando apenas entre políticos e intelectuais desse campo. É a marca de um "clube de garotos", quase uma escrita criptografada!109 Portanto, essa escrita nem está disponível como modelo para o projeto de nação brasileira pensado pelos educadores presbiterianos do Mackenzie. Quanto ao vernáculo brasileiro (PVB), este não está nem mesmo em questão, pois a escola organizada pelos estadunidenses tem a função precípua de formar uma elite de "escolhidos" seguindo sempre a máxima bíblica presente no livro de São Mateus, algumas vezes mencionada neste trabalho, marcando a diferença entre a gramática usada pela elite e aquela usada pelo povo.

Nesse momento, uma concorrência entre, pelo menos, três gramáticas estava estabelecida. Elas disputavam o status de língua legítima, mas, no entanto, a perpetuação da língua legítima depende de uma criação contínua que se opera em meio às diferentes autoridades envolvidas. As gramáticas do PE, do PEPR e a do PLB, disputando o monopólio da imposição da língua legítima. Dissemos três (mas não quatro, como outrora) porque o contexto social mackenzista excluía automaticamente o PVB - usado pelas massas populares e, por isso mesmo, fora da arena linguística na qual só havia espaço para as outras três gramáticas com status privilegiado (BOURDIEU, 2008, p.45).

\section{Considerações finais}

Em texto memorialístico, Boris Fausto nos fala sobre sua passagem pelo colégio Mackenzie como estudante. Seu relato, leve e descontraído, apresenta uma escola onde predominavam as diversidades étnica, racial e religiosa e respectiva tolerância entre esses diversos segmentos. Segundo ele, "o Mackenzie se diferenciava, em termos gerais, por abrigar em maior número a classe média

\footnotetext{
${ }^{109}$ A variedade linguística observada entre os republicanos paulistas, predominantemente enclítica, se encaixa naquilo o que ECKERT (2000) definiu como "comunidade de prática", em que indivíduos constituem uma identidade de grupo a partir de suas práticas sociais, dentre as quais, destaca-se o comportamento linguístico. Assim, os republicanos paulistas não configuram apenas uma categoria social homogênea, como preconiza Labov (2008) em seu conceito de comunidade linguística, mas sim um grupo cuja dinâmica social produz seus próprios sistemas simbólicos (OLIVEIRA; SOARES, 2021, P.150).
} 
estrangeira" (FAUSTO, 1997, p.196-197). Nesse período, final da década de 1930, lá estudavam filhos de sírios, libaneses, ingleses, estadunidenses, italianos, espanhóis, armênios, árabes, protestantes, católicos, judeus - como o próprio Bóris Fausto - junto com imigrantes e descendentes de imigrantes de outras partes do país e do mundo. Essa diferenciação do Mackenzie se dava em relação aos colégios católicos que exigiam compromissos com a religião romana por parte de seu alunado, restringindo desse modo a diversidade étnico-cultural de seu público e se mantendo hostis com seus maiores concorrentes à época: os colégios protestantes.

Podemos afirmar que o protestantismo no Brasil foi um projeto religioso e desdobramento indireto da Reforma europeia, no século XVI, que culminou nos movimentos avivalistas dos Estados Unidos ocorridos a partir do século XVII. Esse projeto também funcionou como um movimento de neocolonização política estadunidense, semelhante ao encabeçado pelas principais potências europeias em seu processo de colonização e expansão comercial dos continentes africano, asiático e da América Latina.

A descrição dos grupos protestantes permitiu a identificação de mais de uma variável na atuação dos missionários no Brasil. Originários dos Estados Unidos, os protestantes que aportaram no Brasil e tiveram atuações no âmbito educacional, já chegaram de seu país natal fragmentados. A laicização do regime de governo republicano oficializou as atividades dos protestantes, o que implementou a formação de diferentes grupos religiosos como o presbiteriano, o metodista e o batista, realinhados a dois grandes blocos: os do norte, que jogavam suas fichas na importância educacional, e os do sul, que se prendiam à evangelização.

Esses blocos fomentaram as igrejas protestantes brasileiras. Os presbiterianos, fixados em São Paulo, eram originários do norte dos Estados Unidos e se dedicavam à estruturação de um complexo educacional, ainda que esse projeto fosse levado a termo por um diretor que se converteu ao protestantismo para assumir tal cargo. Mas esse processo não foi tranquilo, haja vista a dissidência do professor Eduardo Carlos Pereira que, no processo de transformação da Escola Americana para Mackenzie College, se afastou desse grupo para criar a Igreja Presbiteriana Independente, nacional, direcionada para a evangelização, ao contrário do Mackenzie, exclusivamente dedicado à educação. Além disso, ao entrar 
em contato com a cultura brasileira, o protestantismo estadunidense sofreu um choque e se estagnou, visto que seu racionalismo moderno - influenciado pelas revoluções iluministas americana e francesa do final do século XVIII - apresentava diversas incompatibilidades com a cultura católica cujo misticismo arcaizante herdado de Portugal pelo Brasil dificultava os trabalhos de evangelização e conversão promovidos pelos reformadores. Daí que as poucas escolas protestantes - entre as quais o Mackenzie se destaca - foram a maior contribuição dada pelo presbiterianismo estadunidense ao cobiçado progresso da civilização brasileira, muito embora essa contribuição se restringisse a uma pequena elite integrante de uma sociedade laica, cuja ligação com o presbiterianismo histórico de matriz estadunidense que originou a referida escola é muito pequena. De qualquer maneira, o fato de que esses pioneiros introduziram uma nova concepção de educação formal através de seus representantes e métodos de ensino no Brasil, além de construírem uma comunidade estudantil considerável dentro do cenário republicano brasileiro, na virada do século XIX para o $X X$, torna relevante o seu estudo sob diversos pontos de vista, mormente, sob o prisma da história social da língua portuguesa.

A identidade da escola protestante se fez a partir do contraponto com a escola de vertente católica, ainda que esta não fosse mencionada explicitamente, mas sim como "os antigos". O Mackenzie produziu mudanças nos eixos horizontal e vertical do campo educacional: dedicou-se a diferentes níveis de ensino, procurando estabelecer um "nexo lógico e natural entre as disciplinas"; implantou métodos de ensino inovadores baseados na intuição e no trabalho manual; instituiu exames mensais, boletim e tarefas de casa, estimulando a participação dos pais no acompanhamento escolar dos filhos; eliminou os castigos físicos; elaborou os compêndios que serviam de base para o ensino, implantou o jardim de infância acoplado à Escola Normal; criou cursos preparatórios e superiores; construiu edifícios para diferentes funções alocando-os em um espaço amplo de modo a integrar os alunos e integralizar o ensino.

Investindo no lócus social e no sistema educacional que abrangia, com a inclusão de cursos superiores, todos os níveis de ensino, o Mackenzie construiu uma comunidade relativamente estável cuja visibilidade e legitimidade era garantida pela 
sua vinculação à Universidade do Estado de Nova lorque para a equiparação de diplomas.

Se a designação "Escola Americana" e a filiação à universidade americana criavam problemas por extravasarem as fronteiras do nacionalismo, seja pelo controle dos fundos exercido por essa universidade seja pelo controle do padrão de qualidade americano a que estava sujeito o Mackenzie College, os estudos da e pela língua portuguesa (além da geografia e história do Brasil) eram um dos caminhos que firmavam o comprometimento com as questões nacionais, haja vista que o período em análise era, segundo Chauí (2002), marcado pelas ideias nacionalistas articuladas com religião, raça e língua.

O pioneirismo no uso acadêmico e no ensino da língua portuguesa - em período em que o francês dominava como língua de cultura - o investimento na preparação dos compêndios escolares, na formação dos próprios professores e pastores e na criação de sua equipe de futebol, em um espaço integrador dos diferentes institutos (internato, escola, biblioteca, capela, oficinas), atravessados pela associação entre ciência e progresso, com vistas à construção de uma elite científica davam o tom da estabilidade do Mackenzie.

Em um período marcado pela alteração da geração de políticos e pela especialização das atividades políticas e literárias, vislumbrava-se a emergência de diferentes normas cultas da língua portuguesa que deixavam suas pegadas na escolha da colocação pronominal, em particular nas orações infinitivas preposicionadas (OLIVEIRA, 2011, 2013, entre outros). Na virada do século, para além do vernáculo, havia o modelo português, o modelo republicano e o dos literatos brasileiros. A colocação pronominal que permeia as produções escritas na comunidade Mackenzie ressoa o modelo adotado pelos literatos brasileiros, com especial atenção, o de Machado de Assis.

O estudo da colocação pronominal nas produções escritas da comunidade Mackenzie no período da Primeira República mostra que a maneira como os mackenzistas usam os clíticos nesse ambiente sintático não condiz com a norma do PE - enclítica em infinitivas com a preposição a e proclítica com todas as outras preposições -, nem tampouco com a norma do PEPR - enclítica em infinitivas com todas as preposições (SANTOS SILVA, 2012; OLIVEIRA 2013, entre outros). Ao 
compararmos os resultados da amostra mackenzista com aqueles obtidos para o PVB, também não se observa paralelos, já que no vernáculo a próclise é dominante em orações infinitivas com todas as preposições.

Contudo, quando observamos a colocação de clíticos neste ambiente sintático em textos de escritores brasileiros do final do século XIX (PLB) - mais especificamente aqueles estudados por Schei (2002) e Oliveira (2011) - concluimos que a gramática dos referidos escritores guarda semelhanças com a gramática das produções mackenzistas. Além da alta frequência - mas não em caráter absoluto da ênclise, há o compartilhamento de uma peculiaridade interessante: o predomínio da ênclise quando se trata de clíticos acusativos de $3^{a}$. pessoa, independentemente do tipo de preposição que os seleciona, o que enfraquece o argumento do peso da eufonia sobre a relação preposição a e ênclise dos acusativos de $3^{a}$ pessoa.

Havendo, pois, a possibilidade de se aderir a qualquer uma dessas gramáticas, o Mackenzie aderiu ao PLB.

A escolha feita pelo Mackenzie, portanto, conforma-se a um projeto de nação necessário para cumprir seus objetivos missionário e educacional. Ao canonizar os instrumentos de produção dos literatos, o Mackenzie contribui para alimentar a crença em sua legitimidade. Dessa forma, eles (re)produzem o conhecimento e ao mesmo tempo fomentam o reconhecimento da futura norma do português paulista, colocando-se, portanto, como referência seja na codificação linguística seja na decodificação e difusão do código linguístico selecionado como modelo. 


\section{REFERÊNCIAS}

ADDUCI, C. C. Uma nação à paulista. Nacionalismo e regionalismo em São Paulo (1916-1929). Tese de Doutorado. São Paulo: PUC, 2002.

Para um aprofundamento historiográfico: discutindo o separatismo paulista de 1887. In: Revista Brasileira de História. São Paulo, v. 19, no 38, p. 101-124. 1999.

ALGEO, John. The Cambridge History of the English Language - English in North America. v.6. Cambridge: Cambridge University Press, 2001.

ALMEIDA, Jane. Missionárias norte-americanas na educação brasileira: vestígios de sua passagem nas escolas de São Paulo no século XIX. Revista Brasileira de Educação. v. 12 n. 35 maio/ago, p.327-342, 2007.

ALONSO, Ângela. Ideias em Movimento: a geração 1870 na crise do Brasil-Império. São Paulo: Paz e Terra, 2002.

AMERICANO, Jorge. São Paulo naquele tempo (1895-1915), São Paulo: Ed. Saraiva, 1957.

ARISTÓTELES. Retórica. 2. ed. Lisboa: Imprensa Nacional-Casa da Moeda, 2005.

AZEVEDO, F. de. A cultura brasileira. 3. ed. Rio de Janeiro: IBGE, 1958.

BACELLAR, C. A. P. O processo de povoamento do território paulista, séculos XVI a XX. In: OLIVEIRA, Marilza de. Língua portuguesa em São Paulo: 450 anos. São Paulo: Humanitas, 2006, p.19-38.

BARBANTI, M. L. H. Colégios americanos de confissão protestante na província de São Paulo: sua aceitação pelas elites progressistas da época. São Paulo: Didática, 1981.

BARROS, Maria Paes. No Tempo de Dantes. São Paulo: Paz e Terra, 1998. 
BASSANEZI, M.; SCOTT, A. et al. Atlas da imigração internacional de São Paulo: 1850-1950. São Paulo: Unesp, 2008.

BÍBLIA SAGRADA. Nova versão internacional. São Paulo: Geográfica, 2000.

BINZER, Ina Von. Os meus romanos - alegrias e tristezas de uma educadora alemã no Brasil. São Paulo: Paz e Terra, 1994.

BOSI, Alfredo. O Positivismo no Brasil: uma ideologia de longa duração. In: PERRONE-MOISÉS, Leyla (Org.). Do Positivismo à Desconstrução: ideias francesas na América. São Paulo: Edusp, 2004, p.157-181.

BOURDIEU, Pierre. A economia das trocas linguísticas. Trad.: Sergio Miceli et alli. São Paulo: Edusp, 2008.

A economia das trocas simbólicas. São Paulo: Perspectiva, 2007a.

Escritos de educação. São Paulo: Vozes, 2007b.

BRUNO, Ernani. História e Tradições da Cidade de São Paulo, vol. III. Rio de Janeiro: Livraria José Olympio Editora, 1954.

BURKARD, J. F.. Processos de modernização conservadora no Brasil: uma leitura de Recordações do escrivão Isaías Caminha, de Lima Barreto. Dissertação de mestrado: Universidade regional integrada do Alto Uruguai e das Missões, 2014.

BURKE, Peter. Languages and communities in early modern Europe. New York: Cambridge University Press, 2004.

CALVANI, Carlos Eduardo B. A educação no projeto missionário do Protestantismo no Brasil. Rev. Pistis Prax., Teol. Pastor., Curitiba, v. 1, n. 1, p. 53-69, jan./jun. 2009.

CAMACHO, Roberto Gomes. Da linguística formal à linguística social. São Paulo: Parábola, 2013. 
CARPEAUX, Otto Maria. História da literatura ocidental. v.1. Brasília: Edições do Senado federal, 2008.

CARVALHO, José Murilo. A formação das almas. O imaginário da República no Brasil. São Paulo: Companhia das Letras, 1990.

. Os bestializados. São Paulo: Companhia das Letras, 1997.

CASTILHO, A. T. "Linguística histórica e a história do português brasileiro". In: CASTILHO, A. T. (Coord.) História do português brasileiro - O português brasileiro em seu contexto histórico. v.1. São Paulo: Contexto, 2018, p.10-31

CAVALCANTI, H.B. O projeto missionário protestante no Brasil do século XIX: comparando a experiência presbiteriana e a batista. In: Revista de Estudos da Religião. nำ, p.61-93, 2001.

CERTEAU, Michel de. A Escrita da História. Rio de Janeiro: Forense, 2011.

CHAGAS, Valnir. O ensino de $1^{\circ}$ e $2^{\circ}$ graus: antes, agora e depois? São Paulo: Saraiva, 1978.

CHAUÍ, Marilena. Brasil. Mito fundador e sociedade autoritária. São Paulo: Perseu Abramo, 2000.

COLSATO, Andrea. Organização hierárquica e linguística: o modelo jesuítico após a restauração. Tese de doutoramento, Universidade de São Paulo: São Paulo, 2016.

CONDE SILVESTRE, Juán Camilo. Sociolinguística histórica. Madrid: Gredos, 2007.

CONSTITUIÇÃO da Republica dos Estados Unidos do Brazil. Pelotas e Porto Alegre: Echenique \& irmão - Editores - Livraria Universal, 1896. 
CORDEIRO, Ana Lúcia. Religião e projetos educacionais para a nação: a disputa entre metodistas e católicos na Primeira República brasileira. In: Revista Horizonte, Belo Horizonte, v. 4, n.7, p.110-124, dez. 2005.

CORREIO PAULISTANO, São Paulo, 20 de agosto de 1872, p.02

CORRIGAN, John. Protestantism in the United States of America to the Present Day. In: MCGRATH, Alister E.; MARKS, Darren C.(Edit.). The Blackwell companion to protestantism. Oxford: Blackwell publishing, 2004, p.165-180.

CRABTREE, A.R. História dos batistas do Brasil. Rio de Janeiro: Casa Publicadora Batista, 1962.

CYRINO, S. M. L. Observações sobre a mudança no português do Brasil: objeto nulo e clítico. In: ROBERTS, lan; KATO. Mary. Português brasileiro: uma viagem diacrônica. Campinas: EDUCAMP, 1993, p.173-199.

ECKERT, P. Linguistic Variation as social practice. Oxford: Blackwell, 2000.

ELIAS, B. V. Inovação americana na educação do Brasil. Nossa História, São Paulo, n. 23 , p. 81-83, set. 2005.

ELIAS, Norbert e SCOTSON, John L. Os Estabelecidos e os Outsiders: Sociologia das Relações de Poder a partir de uma Pequena Comunidade. Rio de Janeiro:Jorge Zahar, 2000.

ESCOBAR, José Ribeiro. Histórico da instrução pública paulista. In: Revista de educação. v.3. p.158-189, setembro, 1933,.

FAUSTO, Boris. História do Brasil. São Paulo: Edusp/FDE, 1994. 1997. Negócios e ócios - História da imigração. São Paulo: Companhia das letras,

FERREIRA, Valdinei. Protestantismo e Modernidade no Brasil - Da utopia à nostalgia. São Paulo: Reflexão, 2010. 
FREYRE, Gilberto. Casa-grande \& senzala. São Paulo: Global, 2003.

GALVES, Charlotte; ABAURRE, M.B.M. "Os clíticos no português brasileiro: elementos para uma abordagem sintático-fonológica". In: CASTILHO, Ataliba Teixeira de.; BASÍLIO, Margarida (Orgs.). Gramática do Português Falado - Volume IV: Estudos Descritivos. Campinas: Unicamp, 1996, p.280-311.

; OLIVEIRA, Marilza. The debate about Brazilian and European Portuguese. (no prelo)

GARCEZ, Benedicto Novaes. O Mackenzie. 2.ed. São Paulo: Editora Mackenzie, 2004.

GINZBURG, Carlo. Mitos, Emblemas e Sinais. São Paulo: Cia das Letras, 1990.

GODOY, Mahayana. A colocação dos clíticos em ambiente das orações infinitivas introduzidas por preposição no português clássico. 2006. Disponível em:<http://www.tycho.iel.unicamp.br/gentle-wiki/arquivos/e/e0/MAHAYANA_MC -ICRel.pdf> Acesso em 15 jul 2014.

GOMES, Antônio Máspoli de Araújo. Religião, Educação e Progresso. São Paulo: Mackenzie, 2001.

GUTIERRES, Edison Aparecido. Eduardo Carlos Pereira (1855-1923) e o projeto educacional presbiteriano no Brasil. Dissertação de mestrado - Universidade Estadual de Maringá, 2010.

HACK, Osvaldo Henrique. Protestantismo e educação brasileira. São Paulo: Cultura Cristã, 2000. Mackenzie, 2003.

Raízes cristãs do Mackenzie e seu perfil confessional. São Paulo: 
HOBSBAWN, E. J. Nações e nacionalismo desde 1780: programa, mito e realidade. Trad.: Maria Celia Paoli et all. Rio de Janeiro: Paz e Terra, 1990.

HOLANDA, Sergio Buarque de. Raízes do Brasil. 26. ed. São Paulo: Companhia das Letras, 1995.

JARDILINO, José; LIMA, Éber; PROENÇA LOPES, Leandro. Escolas paroquiais protestantes em São Paulo: uma análise histórica do colégio evangélico (19051922). Cadernos de História da Educação. v.10, n.2, p.67-87, jul./dez. 2011. Disponível em: http://www.seer.ufu.br/index.php/che/article/view/14625/8311 Acesso em 08 jan 2015.

KEWITZ, Verena; SIMÕES, José da Silva. "O corpus do projeto para a história do português brasileiro: a constituição de corpora históricos baseada em critérios de tradições discursivas. In: CASTILHO, A. T. (Coord.) História do português brasileiro Corpus diacrônico do português brasileiro. v.2. São Paulo: Contexto, 2018, p.206243.

KOCH, I. V. G. (2006) "Referenciação", In: C.C.A.S. Jubran e I.G.V. Koch (orgs.), Gramática do Português Culto Falado no Brasil. Campinas: Editora da UNICAMP. [381-403]

KOSSOY, BORIS. Realidades e ficções na trama fotográfica. 4⿳亠丷..ed., São Paulo: Ateliê Editorial, 2009.

LABOV, W. Padrões Sociolinguísticos. Trad.: M. Bagno, M. Scherre e C.O. Cardoso. São Paulo: Parábola Editorial, [1972] 2008.

Principles of Linguistic Change (social factors). v.2. Oxford: Blackwell, 2001.

LAVANDERA, B. R.. Where Does the Sociolinguistic Variable Stop? Virginia University: Southwest Educational Development Laboratory, 1977.

LEBRUN, François. As reformas: devoções comunitárias e piedade pessoal. In: CHARTIER, Roger; ARIES, Philippe (Orgs.). História da vida privada: da Renascença ao Século das Luzes. v.3. trad.: Hildegard Feist. São Paulo: Companhia das Letras, 1986, p.16-112. 
LE GOFF, Jacques; NORA, Pierre. História: Novos Problemas. Rio de Janeiro: Francisco Alves Editora, 1995.

LEONARD, Émile G. O protestantismo brasileiro - Estudo de eclesiologia e história social. Rio de Janeiro \& São Paulo: juerpASTE, 1981.

LESSA, Vicente Themudo. Eduardo Carlos Pereira. In: Anaes da 1a. Egreja Presbyteriana de São Paulo (1683-1903). São Paulo: 1a Igreja Presbyteriana Independente de São Paulo, 1938.

LIMA, Lana Lage da Gama. O padroado e a sustentação do clero no Brasil colonial. In: SAEculum - Revista de história. João Pessoa, p.47-62, jan./jun. 2014.

LOBO, Tânia; CARNEIRO, Z. N. Reflexões sobre a constituição e análise de corpora linguísticos históricos e sobre a identificação de perfis sociais de redatores do passado. In: CASTILHO, A. T. (Coord.) História do português brasileiro - Corpus diacrônico do português brasileiro. v.2. São Paulo: Contexto, 2018, p.290-312.

LOPES, Célia Regina. Introdução. In: CASTILHO, A. T. (Coord.) História do português brasileiro - Mudança sintática das classes de palavra: perspectiva funcionalista. v.4. São Paulo: Contexto, 2018, p.11-23.

MAINGUENEAU, D. A propósito do ethos. Tradução de Luciana Salgado. In: MOTTA, A. R.; SALGADO, L. (Org.). Ethos discursivo. São Paulo: Contexto, 2008, p.11-29.

MARCÍlIO, Maria Luiza. História da Escola em São Paulo e no Brasil. São Paulo: Imprensa Oficial do Estado / Instituto Fernand Braudel, 2005.

MARIANI, Bethânia. Colonização linguística. Campinas: Pontes, 2004.

MARSHALL, Peter. Reforma protestante: uma breve introdução. Trad.: Denise Bottman. São PAulo: LP\&M, 2017.

MARTINS, Ana Maria. Gramáticas Históricas do Português. In: Actas do XI encontro nacional da Associação Portuguesa de Linguística, 3.ed. Lisboa: Colibri, p.53-71, 1996. 
. Clíticos na história do português. Tese de doutorado. Lisboa: Faculdade de Letras da Universidade de Lisboa, 1994.

MATOS, Alderi Souza de. O colégio protestante de São Paulo: um estudo de caso sobre o lugar da educação na estratégia missionária da igreja. Fides Reformata, São Paulo, v.4, n.2, p.1-25, jul/dez, 1999.

. Os pioneiros presbiterianos do Brasil. São Paulo: Cultura Cristã, 2004.

. Breve história do protestantismo no Brasil. Vox Faifae: Revista de teologia da faculdade FASSEB. v.3, n.1, p.01-26, 2011.

MAUSS, Marcel. Ensaio sobre a dádiva. São Paulo: Cosaic Naify, 2013.

MCGRATH, Alister E.. Shapers of Protestantism: John Calvin. In: MCGRATH, Alister E.; MARKS, Darren C.(Edit.). The Blackwell companion to protestantism. Oxford: Blackwell publishing, 2004, p.53-65.

MENDONÇA, Antônio Gouvêa. O celeste porvir - A inserção do protestantismo no Brasil. São Paulo: Edusp, 2008.

. "O protestantismo no Brasil e suas encruzilhadas". In: Revista /USP. São Paulo, n.67, p.48-67, 2005.

Edições Loyola, 1990.

; VELASQUES FILHO. Introdução ao protestantismo no Brasil. São Paulo:

MESQUIDA, Peri. Hegemonia norte-americana e educação protestante no Brasil: um estudo de caso. Juiz de Fora: EDUFJF; S. Bernardo do Campo: Editeo, 1994.

MÓDOLO, Marcelo. As construções correlatas. In: ILARI, Rodolfo; NEVES, Maria Helena de Moura. Gramática do Português Culto Falado no Brasil. vol. 2. São Paulo, Unicamp, 2008, p.1089-1102. 
MONARCHA, Carlos. Escola Normal da Praça: o lado noturno das luzes. Campinas: Unicamp, 1999.

MONDADA, L.; DUBOIS, D. Construção dos objetos de discurso e categorização: uma abordagem dos processos de referenciação. In: CAVALCANTE, M. M.; RODRIGUES, B. (Orgs.) Referenciação. São Paulo: Editora Contexto, 2013, p.1752.

MORGAN, Edmund S. The Puritan Ethic and the American Revolution. The William and Mary Quarterly: A Magazine of Early American History, p. 4-43, 1967.

MOTTA, Cassio. Cesário Motta e seu tempo. São Paulo. (s/editora), 1947.

NAGLE, Jorge. Educação e sociedade na Primeira República. São Paulo: Edusp, 2009.

NAVA, Pedro. Balão cativo. 5ª . Ed. São Paulo: Ateliê Editorial, 2000.

NOVAES, José Luís Corrêa. Protestantismo e educação: metodista e liberais na Primeira República. Tese de doutorado em Ciências da Religião. Universidade Metodista de São Paulo, São Bernardo do Campo, 2001.

OITICICA, José. Teoria da correlação. Rio de Janeiro, Organizações Simões, 1952.

OLIVEIRA, Marilza. Pluricentrismo na Arena Linguística. In: Augusto Soares da Silva; Amadeu Torres; Miguel Gonçalves. (Org. ). Pluricentric Languages: Linguistic Variation and Sociocognitive Dimensions. 1 ed. Braga: Universidade Católica Portuguesa, 2011, p. 681-694.

Colocação pronominal: índice social da elite intelectual. In: 61o Seminário do GEL, 2013, São Paulo - USP. Apresentação de Trabalho/Comunicação.

. Ênclise pronominal na fatura linguística do império e da república. In: RAMOS, J.; OLIVEIRA, M. (Orgs.). In: CASTILHO, A. T. (Coord.) História do português brasileiro - Dialetação e povoamento: da história linguística à história social. v.10. São Paulo: Contexto, 2021, p.232-255 
; SOARES, Enedino. Forms of address among law students in 19th century São Paulo: symmetrical relationships. Revista do GEL, v. 18, n. 1, p. 145-168, 2021.

OLMSTEAD, Clifton. Religion in America: past and present. Prentice Hall, Englewood Cliffs, N. J., 1961.

PAGOTTO, Emilio Gozze. Norma e Condescendência, Ciência e Pureza. In: Línguas Instrumentos Linguísticos, n.3, Campinas: Pontes, 1998, p. 49-68.

A posição dos clíticos em português: um estudo diacrônico. Dissertação de mestrado. Campinas: Unicamp, 1992

PEREIRA, Eduardo Carlos. Grammatica expositiva da lingua portugueza. São Paulo: Weiszflog Irmãos, 1907.

PEREIRA, Helcius Batista. A realização do sujeito pela elite paulistana do início do século $X X$ - uma análise em perspectiva gerativista trans-sistêmica. Tese de doutorado. São Paulo: FFLCH-USP, 2010.

PIERSON, Paul E. The Younger Church in Search of Maturity - The History of Presbyterian Church in Brazil from 1910 to 1959. Tese de doutoramento. Princeton Theological Seminary, 1971.

PRADO, Alice da Silva. Um modelo pedagógico para a república: práticas educacionais da Escola Americana em São Paulo (1870-1915). Dissertação de mestrado: PUC-SP, 1999.

RAMALHO, J.P. Colégios protestantes no Brasil: uma interpretação sociológica da prática educativa dos colégios protestantes no Brasil no período de 1870 a 1940. Rio de Janeiro: Zahar, 1975.

REIS FILHO, Casemiro. A educação e a ilusão liberal. Origens da escola pública paulista. Campinas, SP: Autores Associados, 1995. 
RIBEIRO, Boanerges. Protestantismo no Brasil Monárquico. São Paulo: Livraria Pioneira, 1973.

- Protestantismo e cultura brasileira: aspectos culturais da implantação do protestantismo no Brasil. São Paulo: Livraria O Semeador, 1981.

A Igreja Presbiteriana no Brasil - da autonomia ao cisma. São Paulo: O Semeador, 1987.

RIBEIRO, Darcy. O povo brasileiro - a formação e o sentido do Brasil. São Paulo: Companhia das letras, 1995.

RIBEIRO, João. Grammatica Portugueza. 1o grau, Grammatica da infancia. 18. a ed. Rio de Janeiro: Livraria de Francisco Alves, 1900.

RIBEIRO, Julio. Grammatica Portugueza. São Paulo: Typ. de Jorge Seckler, 1881.

RIBEIRO, Priscilla. A ordem de constituintes sentenciais no português paulista. Dissertação de mestrado. São Paulo: Universidade de São Paulo, 2010.

. Língua e sociedade - a ordem na escola republicana paulista. Tese de doutorado. São Paulo: FFLCH-USP, 2015.

RIO, João do. As Religiões no Rio. Rio de janeiro: Editora Nova Aguilar - Coleção Biblioteca Manancial n.ำ 47 - 1976.

ROCHA, llana Peliciari. Imigração internacional em São Paulo: retorno e reemigração, 1890-1920. Dissertação de mestrado. São Paulo: FFLCH-USP, 2007.

SAID ALI, M. Dificuldades da língua portuguesa. Rio de Janeiro: Academia Brasileira de Letras, 2008.

. Grammatica Secundaria da Lingua Portugueza. São Paulo: Companhia Melhoramentos, 1927. 
SANTOS, Edwiges Rosa. O Projeto Educacional Presbiteriano em São Paulo: uma análise sócio-histórica da Escola Americana no período de 1870 a 1912. Tese de Doutorado em Ciências da Religião, PUC-SP, 2010.

SANTOS, José Veloso dos. As contribuições de Horace Lane na instrução pública paulista (1890 - 1910). Dissertação de mestrado. Marília: UNESP, 2011.

SANTOS SILVA, Hosana. O lugar da língua na São Paulo transformada: os usos linguísticos dos intelectuais republicanos paulistas. Tese de doutorado. FFLCH/USP, 2012.

SARTORI, Ana. "In memorian - Klebson Oliveira". In: CASTILHO, A. T. (Coord.) História do português brasileiro - O português brasileiro em seu contexto histórico. v.1. São Paulo: Contexto, 2018, p.128-142.

SCHEI, Ane. "A colocação pronominal na literatura brasileira do século XIX". In: Revista de Filologia e Linguística Portuguesa. №.5, 2002, p.57-84.

SCHNAIDERMAN, Boris. "João Ribeiro atual". In: Revista /USP, São Paulo, n.10, p.65-93, 1971

SCHWARCZ, Lilia. As Barbas do Imperador. São Paulo: Companhia das Letras, 1998.

SCHWARTZMAN, Simon. A política da Igreja e a educação: o sentido de um pacto. In: Religião e Sociedade, 13/1, março, 1986, p.108-127.

SEVCENKO, Nicolau. Literatura como Missão. Tensões Sociais e Criação Cultural na Primeira República. São Paulo: Companhia das Letras, 2003.

SILVA NETO, Serafim da. Introdução ao estudo da língua portuguesa no Brasil. 5.ed. Rio de Janeiro: Presença, 1986.

SILVEIRA, Sousa da. Lições de Português, 9ạ. Ed. Rio de Janeiro: Presença, 1983. 
STEWART, C. T. Mackenzie College e Escola Americana: notas para sua história e organização. São Paulo: [s.n], 1932.

TAPIA, J. E.. Escola americana de Lages 1931-1942. 2007. Disponível em: <www.anpuh.uepg.br/Xxiiisimposio/anais/textos/JOSÉ\%20ELIACHIM\%20BAR ROS\%20TAPIA.pdf > Acesso em: 02 dez 2015.

TEIXEIRA, Ivan. Os Lusíadas. Apresentação e notas Ivan Teixeira, 6a․ Ed., São Paulo: Ateliê Editorial, 2011.

TOCQUEVILLE, Alexis de. Democracy in America. Indianapolis: Liberty Funds, 2010.

VAN DIJK, Teun A.. Ideology: A Multidisciplinary Approach. London: SAGE Publications, 1998.

VIDAL NETO, Jose Bento Cardoso. A Grammatica portugueza, de Júlio Ribeiro: um corte epistemológico na gramaticografia brasileira e a questão da língua portuguesa no Brasil. Dissertação de mestrado. São Paulo: FFLCH-USP, 2010.

WEBER, Max. The protestant ethic and the capitalism spirit. Los Angeles: Roxbury Publishing, 1996.

WEINREICH, Uriel; LABOV, William e HERZOG, Marvin. Fundamentos empíricos para uma teoria da mudança linguística. Trad.: M. Bagno. São Paulo: Parábola Editora, [1968] 2006.

ZACHMAN, Randall C.. "Protestantism in German-speaking Lands to the Present Day". In: MCGRATH, Alister E.; MARKS, Darren C.(Edit.). The Blackwell companion to protestantism. Oxford: Blackwell publishing, 2004, p.23-39.

ZUMTHOR, Paul. A Letra e a Voz. A "literatura" medieval. São Paulo: Companhia das Letras, 1993. 


\section{Fontes primárias}

CAVALHEIRO, Heitor de Vargas. Discurso do orador official. In: Revista de Engenharia do Mackenzie College. Anno 1. n.4. Dezembro de 1915.

CHAMBERLAIN, G. W. Introdução. In: Prospectos: A protestant College at Brazil. São Paulo, 1885.

ESCHOLA AMERICANA. Cartas aos paes de nossos alumnos. 1889, 1890, 1892, 1894, 1895, 1896, 1897, 1898, 1899.

LANE, H. M. Higher Education in Brazil. In: Prospectos: A protestant College at Brazil. São Paulo, 1890.

LISBOA, Miguel A.. A instrucção scientifica e o caracter. In: Revista de Engenharia do Mackenzie College. Anno 1. n.4. Dezembro de 1915.

MACKENZIE COLLEGE, President's report to the board of trustee, 1909, p.19.

PROGRAMMA do curso superior da Eschola Americana, 1894.

PROSPECTO Mackenzie College, 1893.

PROSPECTO Mackenzie College, 1900.

PROSPECTO Mackenzie College, 1901.

PROSPECTO Mackenzie College, 1909

REDACÇÃO. Engenheirandos de 1915 - As festas de encerramento das aulas - O discurso do paranympho, Dr. Arrojado Lisboa - O banquete que lhe foi offerecido. In: Revista de Engenharia do Mackenzie College. Anno 1. n.4. Dezembro de 1915. 
RELATÓRIOS anuais da Igreja Presbiteriana, 1871/1872.

REVISTA AVATAR. São Paulo, 1917-1918. (2 edições)

REVISTA DE ENGENHARIA MACKENZIE COLLEGE. São Paulo, 1915-1920.

REVISTA PROGRESSO. São Paulo, 1908-1909.

STEIDEL, F. V.. Discurso de paranympho. Aos bacharelandos em Sciencias Commerciaes do Mackenzie College em 24 de novembro de 1923.

Discurso de Paranimpho pronunciado pelo Dr. Rudolf Kesselring. In: Revista de Engenharia do Mackenzie College, anno II, dezembro de 1916, n..08, p.58) 